Universidade de São Paulo - Instituto de Biociências

Departamento de Zoologia

\title{
Revisão Sistemática de Promitobates Roewer 1913 e Análise Filogenética de Mitobatinae Simon 1879 (Arachnida, Opiliones, Gonyleptidae)
}

\section{Cibele Bragagnolo}

Tese apresentada ao Instituto de Biociências da Universidade de São Paulo, para a obtenção de Título de

Doutor em Ciências, na Área de Zoologia.

Orientador (a): Prof. Dr. Ricardo Pinto-da-Rocha

São Paulo

2009 
Bragagnolo, Cibele

Revisão Sistemática de Promitobates Roewer 1913 e Análise Filogenética de Mitobatinae Simon 1879 (Arachnida, Opiliones, Gonyleptidae)

Páginas i-x; 1-142.

Tese (Doutorado) - Instituto de Biociências da Universidade de São Paulo. Departamento de Zoologia.

1. Sistemática de Opiliones 2. taxonomia de Gonyleptidae 3. Mata Atlântica 4. Universidade de São Paulo. Instituto de Biociências. Departamento de Zoologia

Comissão Julgadora:

Prof.(a). Dr.(a).

Prof.(a). Dr.(a).

Prof.(a). Dr.(a).

Prof.(a). Dr.(a).

Prof.(a). Dr.(a). Ricardo Pinto-da-Rocha

Orientador(a) 
Não poderia começar esta seção se não fosse agradecendo ao Ricardo. Meu orientador, meu amigo, a quem devo minha formação e muito de tudo o que me tornei hoje. Se a junção entre uma orientação paciente e interessada a uma amizade sincera não é algo trivial, ele soube fazê-la tornar-se simples e natural.

Um obrigado mais que merecido aos meus pais, Silvio e Luci, que sempre digo serem especiais. Certamente minha chegada aqui estava muito longe dos planos iniciais deles, mas tão incrivelmente batalharam pelas nossas vidas, que certamente são merecedores de todos os agradecimentos deste mundo.

Um muito obrigado ao Gabriel, um anjo no meu caminho, que com sua tranqüilidade e paciência infinita, foi o grande responsável por manter minha integridade mental nos últimos meses de tese, dedicando a mim sempre muito amor e carinho. É claro, um muito, muito obrigada à Samara, minha irmã e a maior companheira da minha vida, por tantas conversas, por muitas vezes acreditar mais em mim do que eu mesma.

Sinceros agradecimentos ao Adriano B. Kury, o Adrik, primeiramente por ter consentido que eu trabalhasse com seu grupo taxonômico tão querido. Mas, principalmente por ter sempre me fornecido toda a ajuda e material necessário para o desenvolvimento desse projeto.

Também tenho que agradecer a todos do Museu de Zoologia. Ao diretor, Dr. S. A. Vanin, pelo acesso às dependências; ao L.R.L. Simone pelas agradáveis conversas; à Lara, que sempre pacientemente me auxiliou nas imagens de microscopia; ao Ismael, que nunca desistiu da dificil tarefa de limpar o laboratório; a todas as meninas da biblioteca, pela atenção e dedicação. Aos amigos, que são tantos, afinal são dez anos, que será impossivel nomear um a um. Citarei os nomes dos mais próximos, daqueles que diariamente fazem meu dia mais alegre e feliz - Vivinha, Eric, Aninha, Vanessa, Paty, Daniel, Jaiminho, Portuga... mas há muitos outros, que entre laboratórios e cafés, bares e cervejas, contribuíram muito, tanto para as discussões, quanto para as descontrações durante esta tese. 
Um agradecimento muito especial a todos os integrantes, atuais e antigos, alunos e docentes, do LAL (por ordem alfabética): Bruno - novinho na área, mas já é do LAL!; Francês - mais do que um amigo querido, meu grande companheiro para tudo e todas as horas; MBS - um querido amigo, sempre com valiosíssimos comentários e sugestões sobre cladística e sistemática; Patrão - apesar do pouco convivio, esteve sempre disposto a ajudar no que foi preciso; Pirata - sempre brilhante, sempre com uma sugestão incrivel; Pudim - sempre tão dedicado a tudo, dos opiliões aos amigos, sem distinção; Sabrina - querida amiga, sempre disposta a abrir mão de si mesma para nos ajudar; Teté - sempre tranqüilo, mas com valiosas contribuições a oferecer; e Zé grande ex-companheiro de museu, amigo eterno, que falta faz suas risadas e seus conhecimentos filogenéticos!. Cada um teve a sua importância, a sua particularidade, mas todos foram (e os que acham que ainda não foram, esperem, pois ainda serão!) fundamentais na minha formação. Mas o LAL é sem dúvida muito mais que um laboratório que auxilia na formação intelectual, tenho certeza que a amizade e união entre nós é uma raridade que tenho muito orgulho e gratidão em fazer parte.

Aos meninos e meninas do Museu Nacional e do Instituto Butantan, que sempre me receberam com muito carinho. Um obrigado especial a Cris Rheims, pela amizade, confiança e gentil correção do inglês.

Aos Profs. Drs. Fernando P. Marques, Antonio C. Marques e Pedro Gnaspini pelas disciplinas de sistemática e teoria e métodos de inferência filogenética. Agradeço-lhes também pelos ensinamentos cladísticos extraclasse e durante minha qualificação para o doutorado.

Aos curadores de todos os museus que me emprestaram material que solicitei, que foram atenciosos e prestativos: Prof. Dr. Antonio D. Brescovit (IBSP); Dr. Julio C. de Moura-Leite (MHNC); Prof. Dr. Adriano B. Kury (MNRJ); Dr. Peter Jäger (SMFD) e Dr. Christoph Hörweg (NHMW).

Á CAPES, pela bolsa concedida e pelo programa PAE, que propiciou o estágio no curso como monitora, permitindo aprendizado na docência. 


\section{RESUMO}

As 10 espécies nominais de Promitobates foram utilizadas na análise cladística da subfamília Mitobatinae. A espécie P. ornatus (Mello-Leitão, 1922), amplamente distribuída e polimórfica, foi decomposta em quatro unidades monomórficas e sua taxonomia testada durante a análise cladística. Outras duas espécies que apresentaram polimorfismos (P. hatschbachi H. Soares, 1945 e P. viridigranulatus Soares \& Soares, 1946) também foram separadas em duas unidades distintas. A análise cladística foi efetuada com mais 20 espécies de Mitobatinae, representando os 11 gêneros que formam a subfamília e mais cinco representantes de Gonyleptidae. A matriz é composta por 75 caracteres, sendo 19 pertencentes à genitália masculina; 27 às estruturas morfológicas externas presentes no escudo dorsal, tergitos livres e pedipalpos; 20 referentes às estruturas presentes nas pernas dos machos e 10 de coloração. Duas árvores igualmente parcimoniosas foram encontradas $(\mathrm{L}=257$, C.I=0.38; R.I=0.72). Mitobatinae é monofilético, sustentado por cinco sinapomorfias não ambíguas e grupo-irmão de Despirus parvulus (Roewer, 1927). Mitobatinae é composto por dois grandes clados; [1] um grupo que possui corpo grosseiramente retangular e machos e fêmeas com a coxa e o trocânter IV inermes, ou com apófises muito reduzidas, incluindo os gêneros: Ischnotherus, Encheiridium, Metamitobates, Ruschia, Mitobatula e Mitobates e [2] um segundo grupo que apresenta corpo grosseiramente piriforme e dimorfismo sexual na coxa e trocânter IV, com os machos apresentando principalmente forte armação externa na coxa e apófises no trocânter, incluindo os gêneros: Discocyrtoides, Longiperna, Neoancistrotus e Promitobates.

O gênero Promitobates Roewer 1913 é revisado e uma classificação é proposta baseada nos resultados da análise cladística. O gênero era composto por 10 espécies nominais, destas, quatro são consideradas válidas: P. bellus (B. Soares, 1945); P. hatschbachi H. Soares, 1945; P. ornatus (Mello-Leitão, 1922) e P. viridigranulatus (Soares \& Soares, 1946). Três sinonímias são propostas: $P$. hauseri (Sylhavý, 1979) é considerado sinônimo de $P$. viridigranulatus, P. margaritatus Roewer, 1931, sinônimo de $P$. ornatus e $P$. mendax H. Soares, 1945, sinônimo de P. hatschbachi. P. granulosissimus 
Mello-Leitão, 1932 e $P$. hexacanthus Koch, 1839 são consideradas species inquirendae. Com base nos resultados da análise de $P$. ornatus separado em unidades distintas na análise cladistica, $P$. intermedius e $P$. nigripes são revalidadas e, juntamente com $P$. ornatus, abrigam as quatro unidades monomórficas do complexo $P$. ornatus. Quatro espécies novas são descritas: $P$. sp.n1 (localidade-tipo: Ano Bom, Santa Catarina); P. sp. n2 (localidade-tipo: Reserva Morro Grande, São Paulo); P. sp.n3 (Localidade-tipo: Ribeirão Pires, São Paulo) e P. sp.n4 (Localidade-tipo: Jacarepaguá, Rio de Janeiro). 
A cladistic analysis of the subfamily Mitobatinae is presented. All 10 of the currently valid species of the genus Promitobates Roewer, 1913 were taken into account. Promitobates ornatus (Mello-Leitão, 1922), a polymorphic and widespread species, was initially broken into four sub-units and it's taxonomy addressed with the results of the cladistic analysis. The other two polymorphic species, P. hatschbachi H. Soares, 1945 and P. viridigranulatus Soares \& Soares, 1946, were also broken into two sub-units. In addition to these species, the cladistic analysis was performed with 20 other Mitobatinae species, representing the 11 genera of the subfamily, and 5 species of other Gonyleptidae genera. The character matrix comprised 75 characters: 19 from male genitalia, 27 from the general external morphology, 20 from male legs and 10 from coloration. Two equally parsimonious trees were obtained $(\mathrm{L}=257$, C.I=0.38; R.I=0.72). Mitobatinae arose as a monophyletic group, sister to Despirus parvulus (Roewer, 1927). The subfamily was divided into two major groups: [1] one that possesses the body roughly rectangular and males and females with coxa and trochanter IV without large apophysis, including the genera: Ischnotherus Kury, 1991, Encheiridium Kury, 2003, Metamitobates Roewer, 1913, Ruschia Mello-Leitão, 1940, Mitobatula Roewer, 1931 and Mitobates Sundevall, 1833 and [2] one that possesses the body roughly piriform and an evident sexual dimorphism of coxa and trochanter IV, with males with a large apophysis on coxa and tubercles on trochanter IV, including the genera: Discocyrtoides Mello-Leitão, 1923, Longiperna Roewer, 1929, Neoancistrotus Mello-Leitão, 1927 and Promitobates.

A taxonomic review of the genus Promitobates Roewer 1913 and a new classification, supported by the cladistc analysis results, are presented . Promitobates comprised 10 described species of which four are considered valid: P. bellus (B. Soares, 1945); P. hatschbachi H. Soares, 1945; P. ornatus (Mello-Leitão, 1922) and P. viridigranulatus (Soares \& Soares, 1946). The following species are synonymized: $P$. hauseri (Sylhavý, 1979), considered a senior synonym of $P$. viridigranulatus (Soares \& Soares, 1946); P. margaritatus Roewer, 1931 considered a senior synonym of $P$. ornatus (Mello-Leitão, 1922) and $P$. mendax H. Soares, 1945, considered a senior synonym of $P$. 
hatschbachi H. Soares, 1945. Promitobates granulosissimus Mello-Leitão, 1932 and $P$. hexacanthus Koch, 1839 are considered species inquirendae. Based on the results of the cladistc analysis, with $P$. ornatus separated in four subunits, P. intermedius (Mello-Leitão 1935) and P. nigripes (Mello-Leitão, 1935) are revalidated. Four new species are described: $P$. sp. $n 1$ (type-locality: Ano Bom, Santa Catarina); P. sp. n2 (type-locality: Reserva Morro Grande, São Paulo); P. sp.n3 (type-locality: Ribeirão Pires, São Paulo) and P. sp.n4 (typelocality: Jacarepaguá, Rio de Janeiro). 


\section{INTRODUÇÃO} . .1

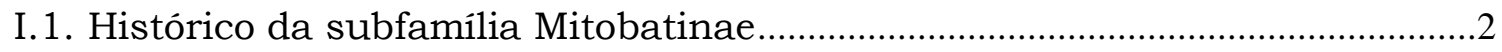

I.2. Histórico do gênero Promitobates Roewer, 1913 ..................................................5

II. OBJETIVOS. .8

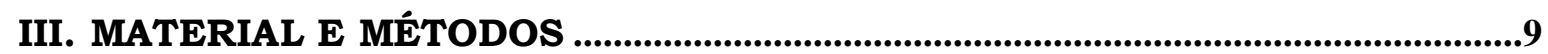

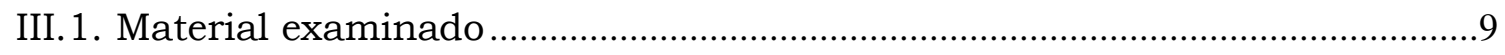

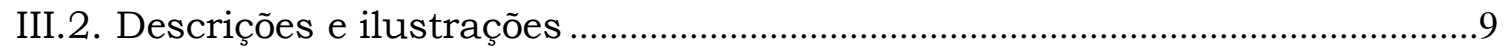

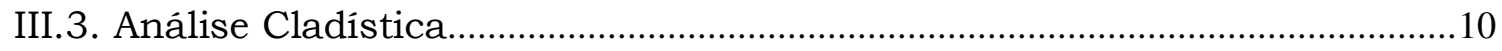

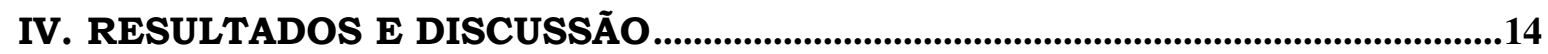

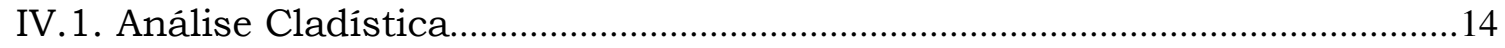

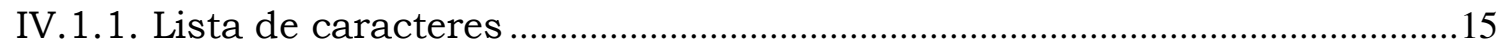

IV.1.2. Padrões gerais e discussão dos caracteres ..................................................48

IV.1.3. Relação entre os gêneros de Mitobatinae ........................................................49

IV.1.4. Análise cladística - hipóteses alternativas....................................................51

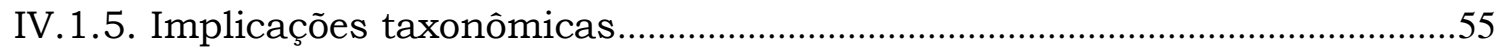

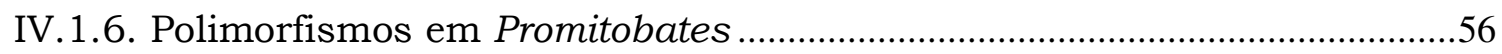

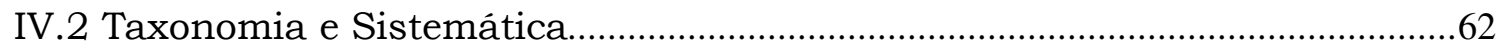

IV.2.1. Chave para os machos de Promitobates ......................................................62

IV.2.2. Características gerais e chave para as fêmeas de Promitobates................63

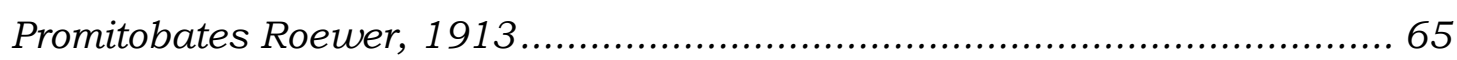

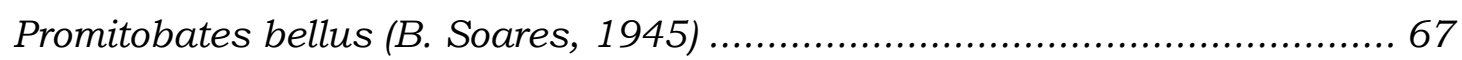

Promitobates difficilis (Mello-Leitão, 1931)....................................... 70

Promitobates hatschbachi $H$. Soares, 1945 .......................................... 73

Promitobates intermedius (Mello-Leitão, 1935) nova combinação................. 77

Promitobates nigripes (Mello-Leitão, 1935) nova combinação...................... 80

Promitobates ornatus (Mello-Leitão, 1922) ......................................... 84

Promitobates viridigranulatus (Soares \& Soares, 1946)........................... 88

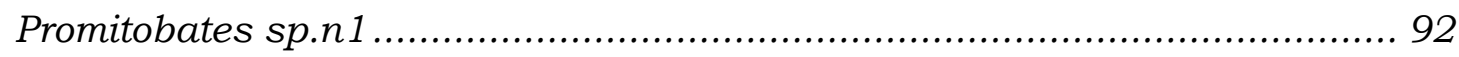

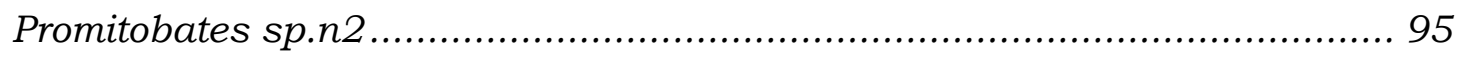




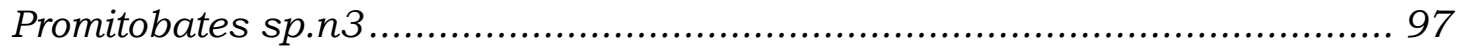

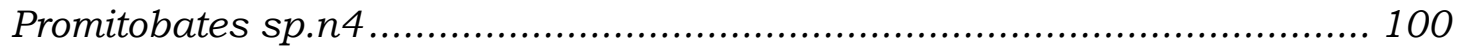

Species inquirendae .............................................................. 103

Promitobates granulosissimus Mello-Leitão, 1932 ................................ 103

Promitobates hexacanthus (Kollar in Koch, 1839)................................ 103

V. CONCLUSÕES

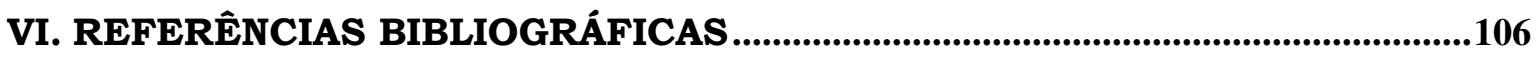

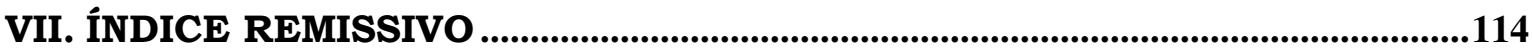




\section{INTRODUÇÃO}

Os opiliões estão entre os aracnídeos mais antigos, com registro fóssil datando do Devoniano (Dunlop, 2007). Atualmente existem mais de 6.000 espécies descritas, o que representa a terceira maior diversidade dentro de Arachnida, sendo inferior apenas à Acari e Araneae (Machado et al., 2007). A ordem foi proposta por Sundevall (1833) e possui como autapomorfias o alongamento do segundo par de pernas para função predominantemente sensorial, articulação típica entre o trocânter e o fêmur, presença de estigmas traqueais pareados no segmento genital, transferência direta de espermatozóides através de um pênis/espermatopositor e presença de um par de glândulas odoriferas (Schultz, 1990).

A ordem encontra-se dividida em quatro subordens: Cyphophthalmi, Dyspnoi, Eupnoi e Laniatores. Os Laniatores compreendem cerca de 70\% da diversidade total da ordem, com cerca de 3.900 espécies descritas (Kury, 2003). Destas, mais de 2.400 ocorrem em regiões tropicais (Kury, 2003). A família Gonyleptidae, a maior família de Laniatores, possui 16 subfamílias e 823 espécies descritas (Kury, 2003), todas neotropicais e é dominante na Mata Atlântica do Brasil, com cerca de 200 espécies exclusivas nesse bioma (da Silva, 2008). Das 16 subfamílias de Gonyleptidae, nove são exclusivas da Mata Atlântica e outras duas possuem distribuição predominantemente nessa área (Pinto-da-Rocha et al., 2005). Apesar da importância do grupo, a sistemática de opiliões neotropicais somente tem recebido um tratamento mais adequado nas últimas duas décadas, com os trabalhos sistemáticos e cladísticos utilizando um grande número de caracteres, tanto da morfologia externa quando da genitália masculina (Pinto-daRocha, 1997; Acosta, 2001; da Silva 2002; Pinto-da-Rocha, 2002; Pinto-daRocha \& Kury, 2003).

Anteriormente a essa geração, a sistemática de opiliões seguia o que se costuma denominar de "Sistema Roeweriano" de classificação, em referência ao alemão Carl Frederich Roewer, que a partir da segunda década do século XX, publicou diversos trabalhos sobre taxonomia de opiliões. Os trabalhos de Roewer representaram um grande avanço na sistemática de opiliões, pois foram os primeiros a conter descrições e ilustrações padronizadas, cabendo aqui destacar sua principal obra, "Die Weberknechte der Erde", em 1923. Entretanto, os critérios de classificação criados por ele, onde eram atribuídos "certos valores" 
aos caracteres, além de muito subjetivos, criaram uma rigidez que impedia o uso de outros caracteres (Pinto-da-Rocha, 1997). Devido a isto, vários indivíduos de uma mesma espécie foram incluídos em gêneros e até subfamílias diferentes (Kury, 1991d). Além disso, nesse sistema, a variabilidade intraespecífica não era contemplada, fazendo com que indivíduos da mesma espécie nominal fossem descritas com nomes diferentes (Kury, 1990a). Apesar das falhas do sistema roeweriano, ele influenciou pesquisadores contemporâneos e subseqüentes, perdurou por muitos anos, mudando apenas recentemente, com os autores das últimas décadas.

\section{I.1. Histórico da subfamília Mitobatinae}

A subfamília Mitobatinae foi descrita por Simon (1879), e definida pelos caracteres: palpos robustos, mais longos que o corpo, de fêmur espesso e comprimido, ligeiramente curvo; escudo dorsal sempre mais longo que largo, piriforme atenuado ou quase paralelo. Simon incluiu em Mitobatinae seis gêneros: Mitobates Sundervall 1833, Goniosoma Perty 1833, Asarcus Koch 1839, Phalangodus Gervais 1842, Ampycus Simon 1879 e Cranaus Roewer 1915. Destas, somente o gênero-tipo permaneceu na subfamília. $O$ trabalho não contém uma única ilustração e as descrições pouco detalhadas são insuficientes para a identificação das espécies. Simon (1879) ainda sinonimizou erroneamente a espécie Mitobates triangulus e Goniosoma conspersum. Kury (1991a), propôs à Comissão Internacional de Nomenclatura Zoológica a precedência do nome $G$. conspersum sobre Mitobates triangulus. Entretanto, sua proposta não foi aceita e M. triangulus continua sendo considerada a espécie-tipo da subfamília.

Roewer (1913), removeu de Mitobatinae Goniosoma, Asarcus, Phalangodus, Cranaus e Ampycus, criou mais quatro genêros - Promitobates, Metamitobates, Metasarcus e Neomitobates, e incluiu dois antigos - Ancistrotus Koch 1939 e Leptocnema Koch 1939. Destes, apenas dois, Promitobates e Metamitobates, permanecem na subfamília até o presente. Roewer (1913) ainda destacou a característica mais marcante da subfamília que são os fêmures IV do macho extremamente longos e inermes. Entretanto, esta mesma característica foi definida para a subfamília Bourguyiinae, criada por Mello-Leitão (1923). A única característica que diferenciava os dois grupos era o número de sulcos transversais no escudo dorsal: cinco nos Bourguyiinae enquanto nos Mitobatinae o quarto sulco é obliterado pela fusão das áreas III e IV. Entretanto, essa 
característica é bastante variável e desta maneira, diversos gêneros de Mitobatinae foram incluídos em Bouguyiinae e vice-versa. Em 1923, Roewer incluiu Bugabitia à subfamilia e em 1931, incluiu mais quatro gêneros Mitoperna, Mitobatoides, Roeweria e Mitobatula.

Posterior aos trabalhos de Roewer, várias décadas se passaram sem que nenhum autor devotasse especial atenção à subfamília. Desde o final da década de 40, onde no catálogo de Soares \& Soares (1949) eram reconhecidos 15 gêneros e 58 espécies em Mitobatinae (tabela 1), nenhuma mudança ocorreu, até o final da década de 1980, com os trabalhos de Adriano B. Kury (1989a; 1989b, 1990a; 1990b, 1991a; 1991b; 1991c, 1992). Esses trabalhos resultaram em diversas sinonimias e transferências de gêneros dentro da subfamília. Dentre as principais modificações dos gêneros de Mitobatinae realizadas por Kury entre as décadas de 1990 até a publicação do seu catálogo em 2003, cabe citar as transferências de Iporangaia e Leptocnemus para Progogyleptoidellinae (Kury \& Pinto-da-Rocha, 1997 e Kury, 1994a, respectivamente) Asarcus e Cnemoleptes para Bourguyiinae (Kury, 1994b e Kury, 2000 - o último foi sinonimizado com Asarcus por Yamaguti \& Pinto-da-Rocha, 2009), Bugabitia para Manaosbiidae (Kury, 1997), Metasarcus para Metasarcinae (Kury, 1994b), Mitobatulina para Cranaidae (Kury, 2003), Mitoperna para Gonyleptinae (Kury, 1995) e Roeweria para Pachylinae (Kury, 2003). O mesmo autor também criou dois novos gêneros, Ischnotherus (Kury, 1991b) e Encheiridium (Kury, 2003). No catálogo sobre os Laniatores do Novo Mundo (Kury, 2003), Mitobatinae é composta por 11 gêneros e 45 espécies (tabela 1).

A única hipótese filogenética disponível para a subfamília Mitobatinae foi a dissertação de mestrado não publicada realizada por Kury (1991d). Nesse trabalho, o autor propõe uma hipótese de parestesco para os 
Tabela 1. Sinopse da classificação da subfamília Mitobatinae Simon, 1879 segundo Soares \& Soares (1949) e Kury (2003).

\begin{tabular}{|l|c|l|c|}
\hline $\begin{array}{c}\text { Situação taxonômica de Mitobatinae } \\
\text { em 1949 (Soares \& Soares, 1949) }\end{array}$ & \multicolumn{2}{c|}{$\begin{array}{c}\text { Situação taxonômica de Mitobatinae } \\
\text { emoo3 (Kury, 2003) }\end{array}$} \\
\hline Ascistrotellus Roewer, 1923 & 23 & Despirus Roewer, 1929 & 1 \\
Bugabitia Roewer, 1913 & 6 & Discocyrtoides Mello-Leitão, 1929 & 1 \\
Cnemoleptes Mello-Leitão, 1935 & 1 & Encheiridium Kury, 2003 & 2 \\
Iporangaia Mello-Leitão, 1935 & 1 & Ischnotherus Kury, 1991 & 2 \\
Leptocnemus Koch, 1839 & 1 & Longiperna Roewer, 1929 & 9 \\
Metamitobates Roewer, 1913 & 1 & Metamitobates Roewer, 1913 & 1 \\
Metaroeweria Mello-Leitão, 1936 & 4 & Mitobates Sundervall, 1833 & 4 \\
Metasarcus Roewer, 1913 & 1 & Mitobatula Roewer, 1931 & 1 \\
Mitobates Sundervall, 1833 & 1 & Neoancistrotus Mello-Leitão, 1927 & 12 \\
Mitobatula Roewer, 1831 & 3 & Promitobates Roewer, 1913 & 10 \\
Mitobatulina Mello-Leitão, 1941 & 2 & Ruschia Mello-Leitão, 1940 & 2 \\
Mitoperna Roewer, 1931 & 1 & & \\
Promitobates Roewer, 1913 & 2 & & \\
Roeweria Mello-Leitão, 1923 & 10 & & \\
\hline & 1 & & \\
\hline & 58 & & \\
& & & \\
& & \\
\end{tabular}

gêneros da subfamília, utilizando 16 espécies como terminais, representantes dos 10 gêneros de Mitobatinae, um terminal não-representativo da subfamília, composto por uma espécie de Discocyrtus, além de um ancestral hipotético, onde a matriz foi enraizada. Utilizando 26 caracteres qualitativos e 31 quantitativos, o autor obteve 5 árvores igualmente parcimoniosas e com a implementação de pesagem sucessiva, obteve uma árvore de relacionamento entre os gêneros de Mitobatinae (Figura1). Segundo a hipótese de Kury (1991d), a evolução dentro de Mitobatinae é representada por uma árvore totalmente assimétrica, onde Discocyrtoides ocupa a posição mais basal dentro da subfamília; os gêneros Neoancistrotus e Encheiridium aparecem como grupos-irmãos e Longiperna, que forma um ramo precoce, grupo-irmão do clado Metamitobates + (Ischnotherus + Promitobates + Mitobatula + Mitobates + Ruschia) . 


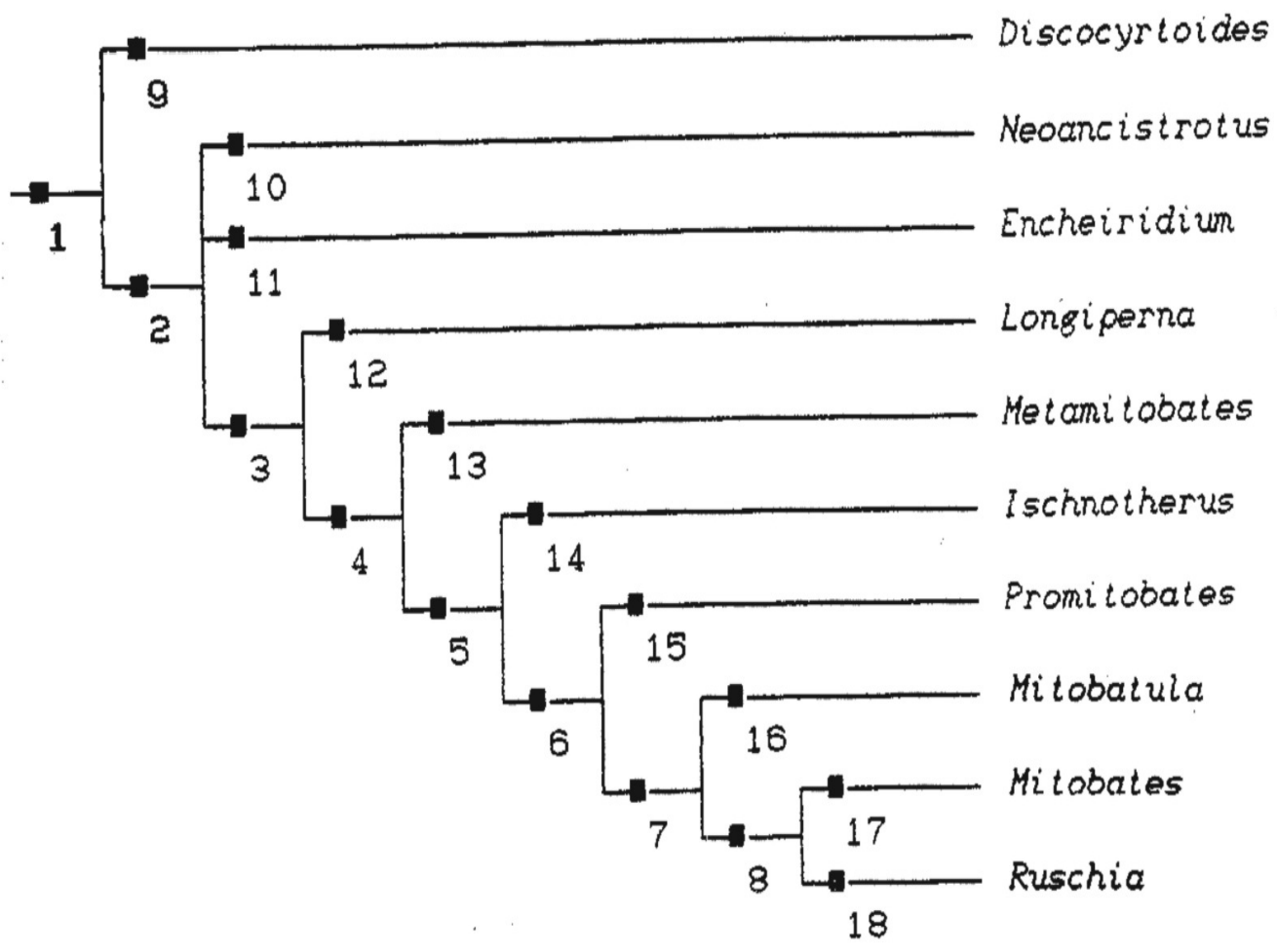

Figura 1. Hipótese de relacionamento entre os gêneros de Mitobatinae Simon, 1879 segundo Kury, 1991(d).

\section{I.2. Histórico do gênero Promitobates Roewer, 1913}

O gênero Promitobates foi criado por Roewer (1913) para abrigar a espécie Ancistrotus hexacanthus Koch 1839, baseada em um único exemplar depositado na coleção Imperial dos Habsburgos, em Viena. Mello-Leitão (1927) estabeleceu o gênero monotípico Promitobatoides e assinalou Neomitobates ornatus, como espécie-tipo. Esse mesmo autor, em 1934, estabeleceu o gênero Batomites descrevendo Batomites spitzi e Batomites difficilis, e no ano seguinte (Mello-Leitão 1935), descreveu $B$. intermedius e $B$. heteracanthus e estabeleceu o gênero Leonardosia com apenas uma espécie, Leonardosia nitida. B. Soares (1943), ao examinar o holótipo de Neomitobates ornatus, com base em características do fêmur do pedipalpo, sinonimizou Promitobatoides com Promitobates e também Batomites com Promitobates, baseado em variações no número de segmentos do 
tarso I. Nesse trabalho, o autor já considerava necessária uma revisão do gênero. O mesmo autor, em 1944, verificando a grande variabilidade na armação dos tergitos livres, sinonimizou Leonardosia com Promitobates, uma vez que a única característica que os diferenciava era a armação do tergito livre III, presente em Leonardosia e ausente em Promitobates. Neste trabalho, o autor novamente ressaltou a necessidade de revisão do gênero, por possuírem espécies bastante afins e de dificil distinção. O grande número de sinonímias feitas por B. Soares gerou um problema taxonômico, já que Promitobates passou a ter diversas espécies nominais sem indicações diagnósticas claras para separá-las. Em 1949 (Soares \& Soares, 1949), o gênero era composto por 10 espécies e definido basicamente pela armação do escudo dorsal e dos tergitos livres e segmentação tarsal. Após este trabalho, assim como aconteceu com a subfamília Mitobatinae, a situação do gênero permaneceu estagnada por várias décadas. Nos anos 90 a o grupo voltou a ser estudado com Kury (1991d), que propôs a sinonímia de $P$. decoratus com $P$. granulosissimus, e de $P$. heteracanthus e $P$. nitidus com $P$. ornatus. Nesse mesmo trabalho, Kury propõe uma mudança na diagnose do gênero, passando a ser definido como "Mitobatinae com cômoro ocular armado com um par de altos espinhos divergentes, contorno do escudo dorsal piriforme, abdome da fêmea fortemente convexo com espinhos da área III muito robustos, pedipalpos de estrutura alongada, armação das tíbias mesal Iili/ Iiili, basitarso I do macho inflado ou não, com 4 (raramente 3) segmentos, basitarsômero 1 da perna IV 3 a 4 vezes maior que o basitarsômero 2 nos dois sexos, fêmur IV 9 vezes mais longo que o comprimento do escudo dorsal no macho, 3 vezes maior na fêmea, ancas IV do macho com apófise apical externa, ancas IV da fêmea com espinho apical externo, padrão de coloração variado, amarelo queimado ou marrom reticulado ou não, com apêndices amarelos ou marrons; placa ventral do pênis de contorno piriforme, com rebordo distal, sem entalhe mediano, ramo ventral da glande promitobatiforme, stylus da glande reto, liso e inflado no ápice” (Kury, 1991d, p.44). Com esta nova disgnose, incluiu em Promitobates três espécies descritas em Ancistrotellus - A. bellus, A. hexacanthus e A. hauseri. Essas mudanças taxonômicas foram incluídas na publicação do Catálogo dos Laniatores do Novo Mundo (Kury, 2003), onde Promitobates é composto por 10 espécies. No entanto, mesmo após a publicação de Kury (2003), a taxonomia do grupo permaneceu imprecisa e a variação intraespecífica das espécies nominais suscitava dúvidas sobre a identificação precisa de algumas de suas linhagens. 
Além disso, espécies de Promitobates possuem uma distribuição geográfica bastante restrita, havendo registro de ocorrência somente na Mata Atlântica entre os estados do Rio de Janeiro, São Paulo, Paraná e Santa Catarina. Entretanto, é bastante comum erros de registros de localidades, principalmente entre autores do século XIX, que de maneira geral, não detalhavam as localidades de coleta. Um exemplo disso é a espécie-tipo, P. hexacanthus Koch 1839, que foi descrita somente com a nacionalidade "Brasil". Posteriormente, a espécie foi registrada por Roewer (1913) para para "Rio Negro, Brasil" e MelloLeitão (1932) interpretou como sendo Rio Negro no Amazonas, localidade que não condiz com a distribuição da subfamília.

Essa distribuição geográfica restrita, associado à homogeneidade do grupo, faz com que uma revisão taxonômica e construção de uma hipótese filogenética para as espécies seja necessária, principalmente frente ao grande crescimento que os estudos sistemáticos com os opiliões têm sofrido nas últimas décadas (ver Pinto-da-Rocha et al., 2007). 
II. OBJETIVOS

- Propôr uma hipótese de relacionamento para os gêneros de Mitobatinae com base na metodologia cladística;

- Revisar as espécies incluídas no gênero Promitobates Roewer 1913 e propôr uma hipótese filogenética para as suas espécies. 


\section{MATERIAL E MÉTODOS}

\section{III.1. Material examinado}

Foram examinados 323 exemplares das seguintes instituições:

IBSP: Instituto Butantã, Laboratório de Artrópodes Peçonhentos, São Paulo. Curador: Antonio Brescovit.

MHNC: Museu de História Natural Capão de Imbuia, Paraná. Curador: J.C. de Moura-Leite.

MZSP: Museu de Zoologia da Universidade de São Paulo, São Paulo. Curador: Ricardo Pinto-da-Rocha.

MNRJ: Museu Nacional do Rio de Janeiro, Rio de Janeiro. Curador: Adriano B. Kury. O material indicado como HEMS (coleção particular da Profa. Helia E. M. Soares) e MLPC (coleção particular Prof. C.F. Mello-Leitão) foi incorporado a essa coleção e preserva sua numeração original.

NHMW: Naturistorishes Museum Wien, Wien. Curador: Christoph Hörweg SMFD: Naturmuseum Senkenberg Frankfurt, Frankfurt. Curador: P. Jäger.

Foram examinados todos os holótipos das espécies de Promitobates, provenientes de empréstimo de material, exceto $P$. granulosissimus, e $P$. hexacanthus, cujo material-tipo está perdido.

\section{III.2. Descrições e ilustrações}

As descrições das espécies seguem a ordem alfabética. Uma vez que as fêmeas possuem mesmo aspecto geral que os machos, para tornar as descrições menos longas, optou-se por omitir as características idênticas ao macho e apresentar apenas as diferenciais. Quanto à terminologia utilizada, seguiu-se Acosta et al. (2007). Assim, grânulos são denominações dadas às microestruturas (menores que $0,01 \mathrm{~mm}$ ) do tegumento, que definem uma determinada aparência à superficie, de acordo com sua densidade. O termo armação se refere às grandes projeções da cutícula (no corpo ou apêndices), podendo ser classificados em: (1) apófises - projeções altas com extremidades afiladas ou rombas, sem um claro limite com a cutícula; (2) espinhos - processos 
de ápice afilado inseridos em algum tipo de soquete (portanto, neste trabalho, restrito aos processos do pedipalpo e pênis) e (3) tubérculos - que são pequenas projeções sem um claro limite com a cutícula, normalmente tão largo quanto alto, afilado ou cilíndrico. Cabe destacar aqui uma pequena modificação à terminologia proposta por Acosta et al. (2007) que facilitará as descrições e será utilizada ao longo do texto. Será considerada armada apenas uma área onde a estrutura, independentemente de ser tubérculos, espinhos ou apófises, se destaca pelo tamanho das demais. Ou seja, numa determinada região ou área do corpo coberta por tubérculos, será considerada armada apenas caso haja um par de tubérculos nitidamente maior que os demais tubérculos que a recobrem.

As ilustrações de morfologia externa foram feitas utilizando-se microscópio estereoscópio acoplado à câmara clara. A metodologia para preparação do pênis segue Pinto-da-Rocha (1997). As estruturas foram observadas e fotografadas através de microscópio eletrônico de varredura LEICA LEO 440, no Museu de Zoologia da Universidade de São Paulo.

Em relação à contribuição da literatura, foram adotadas as seguintes abreviaturas na listagem sinonímica: cat $=$ catálogo; chv = chave; cit $=$ citação; descr $=$ com descrição; rdesc $=$ redescrição; sist = discussão sistemática .

\section{III.3. Análise Cladistica}

A análise cladística foi realizada incluindo todas as espécies de Promitobates e representantes de todos os gêneros de Mitobatinae. Das 10 espécies nominais de Promitobates, foram encontrados polimorfismos em três táxons terminais ( $P$. viridigranulatus, $P$. hatschbachi e $P$. ornatus). Duas delas, $P$. viridigranulatus e $P$. hatschbachi apresentaram variação em apenas dois e três caracteres, respectivamente; já $P$. ornatus foi polimórfico em seis caracteres. Devido a alta incidência de polimorfismos em $P$. ornatus, optou-se por decompor estas espécies em terminais que contemplassem o polimorfismo observado. Assim, $P$. viridigranulatus e $P$. hatschbachi foram analisados em duas subunidades distintas e $P$. ornatus em quatro. Desta maneira, o grupo interno inclui 16 terminais do gênero Promitobates e outras 20 espécies de Mitobatinae (representando 11 gêneros), resultando em 36 terminais de Mitobatinae e mais cinco espécies como grupos-externos (tabela 2). Como grupos-externos, foram 
selecionadas espécies pertencentes à grupos relacionados à Mitobatinae segundo Kury (1992a), Kury \& Pinto-da-Rocha (1997) e Pinto-da-Rocha (2002).

Para a codificação dos caracteres, uma opção válida é a codificação "composta", onde se mantém os padrões observados num mesmo caráter (gerando caracteres multi-estado) utilizando, porém, uma ordenação à priori para manter a informação original. A outra opção, e na qual houve uma tendência neste estudo, é a codificação "redutiva" dos caracteres, onde os padrões são divididos em diversas variáveis construindo-se diversos caracteres binários. Evita-se, assim, quando possível, a construção de caracteres multiestado. Esta forma de codificação, apesar de ter a desvantagem de gerar caracteres inaplicáveis, o que pode levar à reconstruções de árvores espúrias por considerar esses campos como dados existentes, é a que melhor reflete os princípios de independência entre caracteres e não redundância (Strong \& Limscomb, 1999). Entretanto, alguns caracteres multiestado foram criados, uma vez que a transformação da totalidade da matriz em caracteres binários criaria um número muito grande de caracteres não comparáveis. Desta maneira, foram criados 16 caracteres multiestado.

Além da análise com caracteres qualitativos, uma análise posterior foi realizada adicionando-se quatro caracteres quantitativos empregados em Kury (1991d), a fim de comparar os resultados:

- razão entre: largura da coxa IV / distância estigmática dos machos;

- razão entre: largura da coxa IV / largura da área genital dos machos;

- razão entre: fêmur do pedipalpo / comprimento do cefalotórax dos machos;

- razão entre: distância estigmática / largura da área genital dos machos.

Incicialmente foram realizadas duas análises sem pesagem dos caracteres; uma onde os caracteres multi-estado $3,15,19,26,28,52,57$ e 62 foram ordenados, por haver indicativos da série de transformação entre os estados, ou seja, nesses casos, houve claras evidências de similaridade entre os estados ordenados. Para observar os efeitos da ordenação sobre o resultado, foi realizada uma segunda análise com os caracteres não-aditivos utilizando a mesma matriz.

Também foram efetuadas seis análises com pesagem implícita de caracteres (Goloboff, 1993). Este tipo de análise atribui valores mais altos à caracteres com maior ajuste $\left(\mathrm{f}_{\mathrm{c}}\right)$ às árvores. A busca com pesagem implícita procura as árvores que possuem o maior valor de total fit. Esse valor é a somatória do fit de todos os caracteres da matriz, que é obtido segundo a fórmula $f_{c}=k /\left(k+S_{c}\right)$, onde $S_{c}$ é o número de passos do caráter e $\mathrm{k}$ uma constante, que descreve a concavidade da 
função "fit / passos extras", que varia de 1 a 6 (escolhida a priori). Quanto menor o valor de $\mathrm{k}$, mais drástico será o custo para o caráter com passos extras e, portanto, menor sua influência na análise. Como não existe consenso na literatura a respeito do valor mais adequado de $\mathrm{k}$, ou seja, sobre a escolha da intensidade de penalização do caráter, a análise com pesagem implícita foi implementada com todos os valores de concavidade e os resultados discutidos.

A polarização dos caracteres foi feita à posteriori, onde o estado plesiomórfico de cada caráter é decidido no enraizamento do diagrama pela análise de parcimônia de todos os táxons terminais (grupos externos e internos, simultaneamente) (Nixon \& Carpenter, 1993). A matriz de caracteres (tabela 2) foi construída com o auxílio do software NDE 0.5.0 (Page, 2001). Para a análise de parcimônia foi utilizado o programa TNT versão 1.0 (Goloboff, Farris \& Nixon, 2003)

No TNT a matriz foi submetida a uma busca heurística com 500 replicações. O algoritmo heurístico utilizado foi TBR (Tree Bisection Recconection branch swapping) que opera quebrando a árvore em dois diagramas não-enraizados e, posteriormente reconectando essas sub-árvores em todos os ramos possiveis. Se o processo resultar em uma árvore mais parcimoniosa, essa árvore é salva e um novo processo de TBR é realizado. Foram retidos no máximo 100 árvores por replicação. O comando "colapsar árvores após a busca" foi utilizado para que nós sem suporte não fossem mantidos. Os nós de comprimento zero (i.e. sem suporte) presentes em pelo menos uma das árvores encontradas foram colapsados (opção "rule 1" - TNT; Coddington \& Scharff, 1994). Além de realizar a busca com 500 replicações e retidas no máximo 100 árvores por replicação, outras combinações foram testadas, a fim de certificar-se do número de árvores mais curtas encontradas, e se as obtidas foram realmente as mais curtas.

A otimização dos caracteres das análises foi realizada com a ajuda do programa Winclada 1.00.08 (Nixon, 1999). Este programa possibilita a escolha entre a otimização ACCTRAN (Accelerate Transformation), onde as homoplasias são tratadas como um único surgimento e posterior reversão para o estado plesiomórfico; e DELTRAN (Delayed Transformation) que trata as homoplasias como eventos convergentes. As otimizações apresentadas nos cladogramas são ACCTRAN, que, segundo de Pinna (1991) é a forma de otimização que melhor preserva as hipóteses de homologia primária. Entretanto, em casos específicos onde as aquisições independentes pareciam ser eventos igualmente prováveis, a 
otimização DELTRAN também foi discutida. Para facilitar a discussão dos caracteres foi adotada a notação de grupo+, proposta por Amorim (1982).

Para a análise da sustentação dos clados formados, optou-se pelo suporte de Bremer (Bremer, 1994). Este suporte mostra quantos passos a mais (observandose as árvores sub-ótimas) são necessários para um determinado nó colapsar. Para este cálculo, utilizou-se o programa TNT versão 1.0 (Goloboff, Farris \& Nixon, 2003). 


\section{RESULTADOS E DISCUSSÃO}

\section{IV.1. Análise Cladística}

Setenta e cinco caracteres foram criados, sendo 19 pertencentes à genitália masculina; 27 às estruturas morfológicas externas presentes no escudo dorsal, tergitos livres e pedipalpos; 20 referentes às estruturas presentes nas pernas dos machos e 10 de coloração. Os caracteres utilizados em literatura prévia de filogenia de Gonyleptidae (por exemplo, Kury, 1991d, 1994; Pinto-daRocha, 1997, 2002; da Silva 2002, 2008; Yamaguti \& Pinto-da-Rocha, 2009) foram incorporados e/ou adaptados, quando compativeis com o grupo taxonômico aqui analisado. Em relação aos caracteres empregados em Kury (1991), dos 32 caracteres qualitativos empregados, 18 foram incorporados, com nenhuma ou pequenas modificações.

Os demais caracteres não foram empregados pois faziam referência à fêmas $(50 \%)$ e optou-se por não utilizar caracteres exclusivos de fêmeas como fonte de dados filogenéticos na análise; consistiam em caracteres quantitativos que já haviam sido contemplados nos caracteres qualitativos, como a relação entre o comprimento do fêmur IV em relação ao escudo dorsal; relação entre a largura da borda anterior e borda posterior do escudo dorsal e a relação entre a largura do prossoma e do abdômen e relações entre astrágalo e calcâneo dos matatarsos das pernas I a IV. Estes últimos não foram incluídos pois durante a mensuração de um grande número de indivíduos de algumas espécies verificou-se que a variação entre os indivíduos de uma mesma espécie era, em alguns casos, maior que a variação entre as espécies e, nestes casos, somente havendo um grande número de indivíduos de todas as espécies seria possivel obter dados quantitativos representativos.

Os parâmetros comprimento (L), índice de consistência (I.C.) e índice de retenção (I.R.) são referentes ao resultado da análise com 500 réplicas e com pesos iguais (Fig. 2). Os caracteres multiestado 3, 15, 19, 26, 28, 52 e 62 foram tratados como aditivos (Fig. 2). A análise resultou na obtenção de duas árvores igualmente parcimoniosas com 257 passos (C.I=0.38; R.I=0.73). Para fins de otimização e discussão dos caracteres, será utilizada a árvore de consenso 
(L=258, C.I= 0.37; R.I=0.73; Figura 2), cuja otimização aplicada foi ACCTRAN. A matriz utilizada encontra-se no final do trabalho, após as Figuras (tabela 2).

\section{IV.1.1. Lista de caracteres}

\section{GENITÁLIA MASCULINA}

1. Placa ventral - formato do ápice:

$(\mathrm{L}=11 ; \mathrm{I} . \mathrm{C}=0.27 ; \mathrm{I} . \mathrm{R}=0.27)$

0 reto

1. levemente curvado

2. com fenda em $\mathrm{U}$
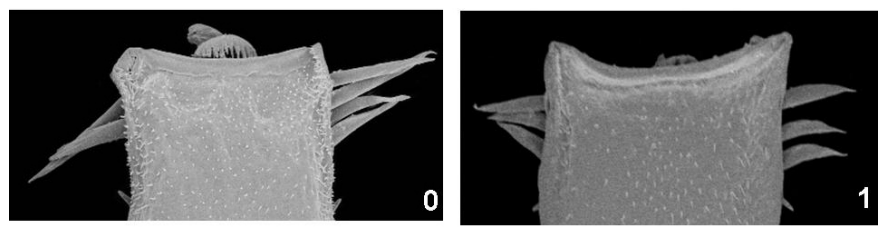

3. com fenda em $\mathrm{V}$

Modificado do caráter
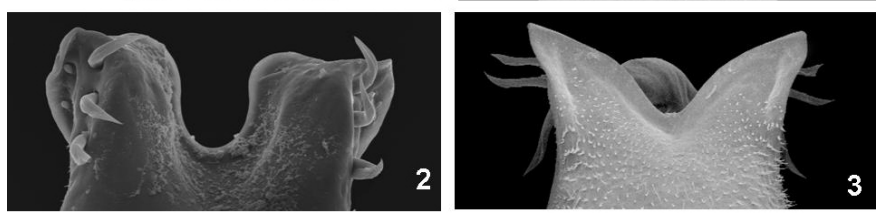

17 de Kury (1991). O estado plesiomórfico é a placa ventral com o ápice reto (0). Muda independentemente para o ápice em forma de " $U$ " (2) em Cobania picea, Caelopygus elegans, Ruschia vellutina e Mitobates pulcher. Com otimização ACCTRAN, muda para ápice levemente curvado (1) em Discocyrtus testudineus, Discocyrtoides nigricans, Longiperna cancellata e no clado Ischnotherus+, mudando para fenda em "V" (3) no clado Ruschia+ (Mitobatula + Mitobates). Optando-se por otimização DELTRAN, a mudança para o estado "2" ocorre independentemente em $D$. testudineus, $D$. nigricans, $L$. cancellata, no gênero Ischnotherus em Metamitobates squalidus. A mudança para ápice com fenda em "V" ocorre em Ruschia+ .

2. Placa ventral - ápice com margens em estrutura arredondada:

$(\mathrm{L}=3 ; \mathrm{I} . \mathrm{C}=0.33 ; \mathrm{I} . \mathrm{R}=0.80)$

0 . ausente

1. presente 
Optando-se por otimização ACCTRAN, o ápice da placa ventral com as laterais arredondadas (1) é sinapomorfia de Promitobates, com reversão em $P$. viridigranulatus e $P$. sp.n1. Com otimização DELTRAN,

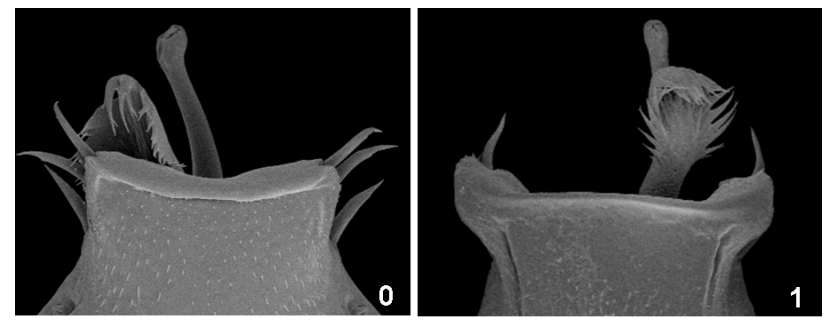
essa característica surge apenas como sinapomorfia do clado Promitobates sp.n2+, compartilhado homoplasticamente com Promitobates bellus e Promitobates sp.n3.

\section{Placa ventral - largura da base em relação ao tronco:}

$(\mathrm{L}=5 ; \mathrm{I} . \mathrm{C}=0.60 ; \mathrm{I} . \mathrm{R}=0.60)$

0 . mais estreita que o tronco

1. mesma largura que o tronco

2. maior que o tronco

3. muito maior que o tronco

O estado plesiomórfico é a região basal da placa ventral com a mesma largura que o tronco (1). Placa ventral começando mais estreita que o tronco (0) ocorre exclusivamente em Pachylus chilensis e a placa ventral maior que o tronco (2) é sinapomorfia do clado Bourguyia albionata+, mudando para muito maior que o tronco independentemente em Metamitobates squalidus, Promitobates viridigranulatus e Longiperna concolor $+L$. cancellata .

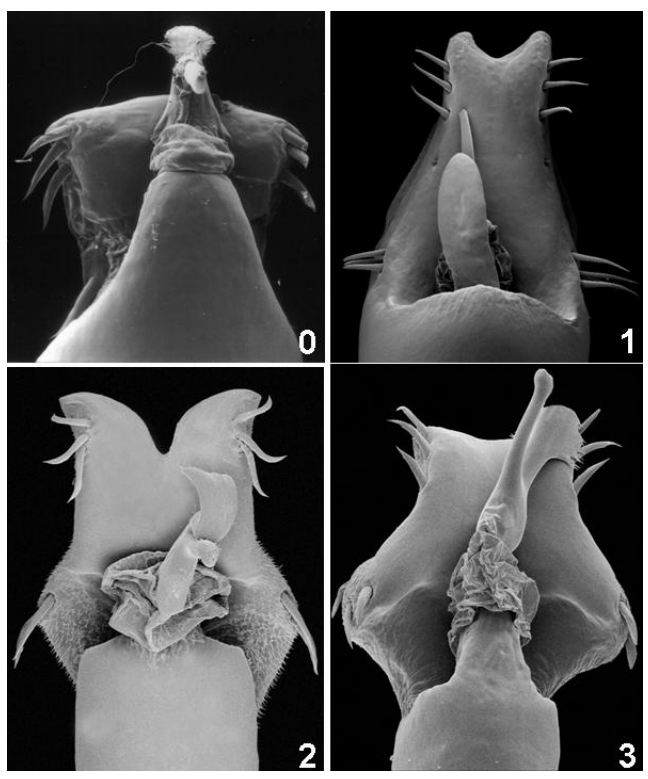

\section{Placa ventral - setas distais:}

$(\mathrm{L}=6 ; \mathrm{I} . \mathrm{C}=0.16 ; \mathrm{I} . \mathrm{R}=0.28)$

0. subapicais (mais de duas vezes o diâmetro do espinho)

1. apicais 
O estado plesiomórfico são setas distais subapicais (0). Setas apicais (1) ocorrem no clado Pachylus chilensis+, com reversões em Discocyrtus
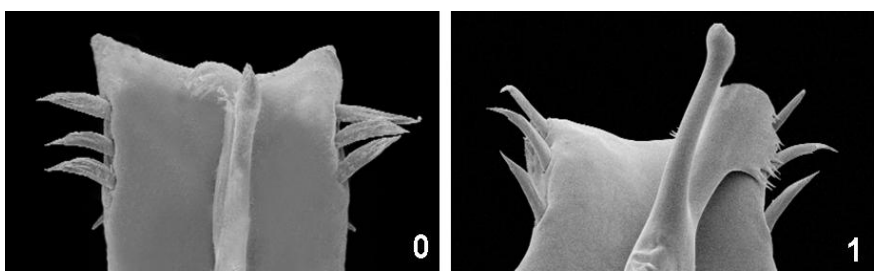
testudineus, Mitobates triangulus, Promitobates sp.n1, Discocyrtoides nigricans, Longiperna coxalis e L. insperata.

\section{Placa ventral - forma dos espinhos apicais:}

$(L=3 ; \mathrm{I} . \mathrm{C}=0.33 ; \mathrm{I} . \mathrm{R}=0.33)$

0. cônicos

1. espatulados

O estado plesiomórfico são os espinhos apicais da placa ventral cônicos (0). A mudança para espinhos espatulados (1) ocorre no clado Pachylus chilensis+, com reversão em Bourguyia albiornata e Longiperna concolor+L.cancellata.
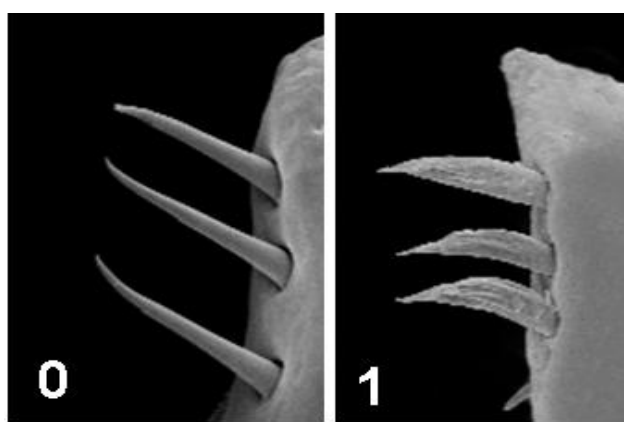

\section{Placa ventral - disposição das setas basais:}

$(\mathrm{L}=7 ; \mathrm{I} . \mathrm{C}=0.42 ; \mathrm{I} . \mathrm{R}=0.73)$

0 verticais

1. fileira com seta basal mais ventral que as superiores

2. forma de $\mathrm{U}$

3. fileira com seta basal dorsalmente disposta

O estado plesiomórfico são as setas ventrais da placa ventral alinhadas verticalcalmente (0), mudando para setas dispostas em "U" (2) no clado Discocyrtus testudineus+. Setas basais em fileira longitudinal, com a seta mais basal disposta ventralmente (1) é encontrado de forma independente em Caelopygus elegans e nos clados Encheiridium ruschï+, Longiperna+ $e^{N e o a n c i s t r o t u s+, ~ c o m ~ m u d a n c ̧ a ~ p a r a ~ f i l e i r a ~ l o n g i t u d i n a l ~ c o m ~}$ 
seta mais basal disposta dorsalmente (3) sendo autapomorfia de Neoancistrotus guapimirim.
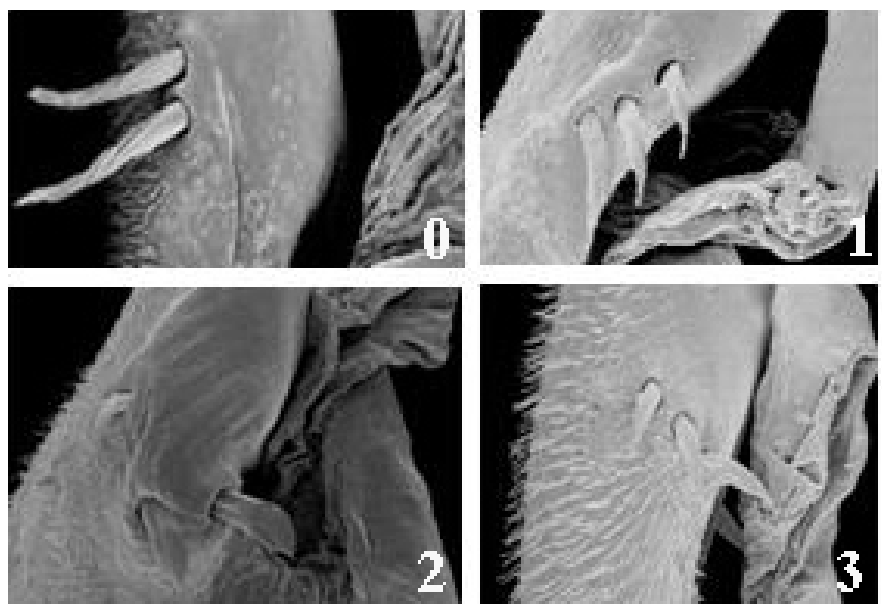

7. Depressão horizontal na altura da base da placa ventral:

$(L=5 ; I . C=0.20 ; I . R=0.66)$

0. ausente

1. presente

O estado plesiomórfico é a ausência de depressão (0). A presença (1) ocorre de maneira independente no clado Pachylus chilensis, Discocyrtus testudineus, Despirus parvulus, Encheiridium ruschii+

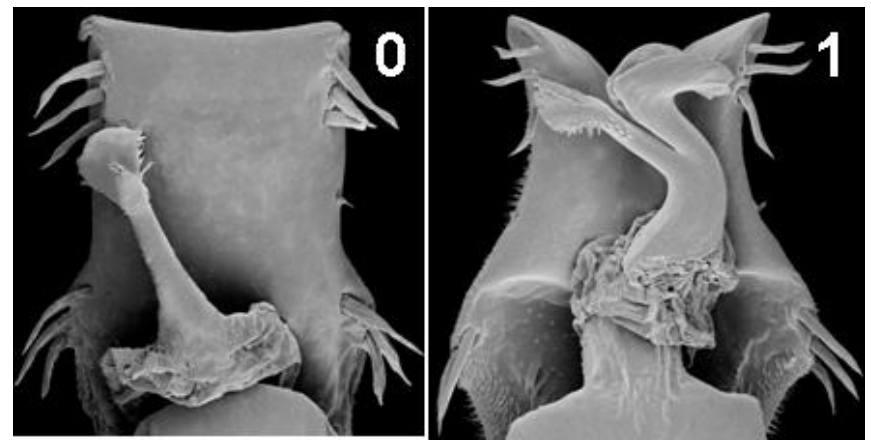
(Metamitobates + Ruschia + Mitobates) e Promitobates.

\section{Estilo - setas :}

$$
(\mathrm{L}=5 \text {; I. } \mathrm{C}=0.20 ; \mathrm{I} . \mathrm{R}=0.75)
$$

0. ausentes

\section{1. presentes}

Equivale ao caráter 20 de Kury (1991d). O estilo liso (0), sem setas, é o estado plesiomórfico. A presença de
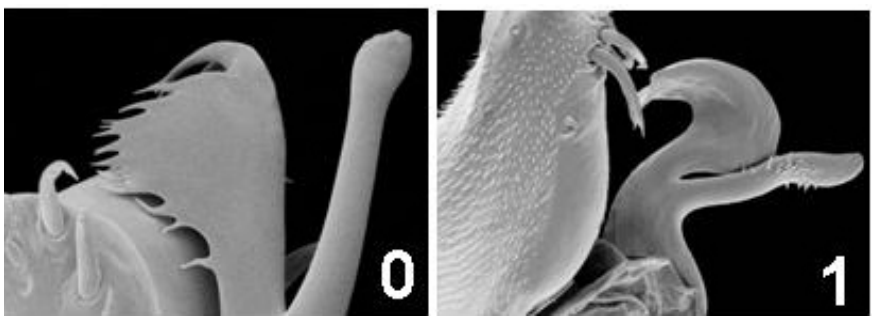

setas no estilo (1) ocorre no clado Pachylus chilensis+, com perda em $B$ 
albiornata, Promitobates e no clado Encheiridium ruschï+, tendo sido novamente readquirido em Mitobates inermis+.

\section{Estilo - formato:}

$(L=4 ; I . C=0.5 ; I . R=0.80)$

0. reto

1. sinuoso dorsal

2. sinuoso

ventral

Modificado do caráter

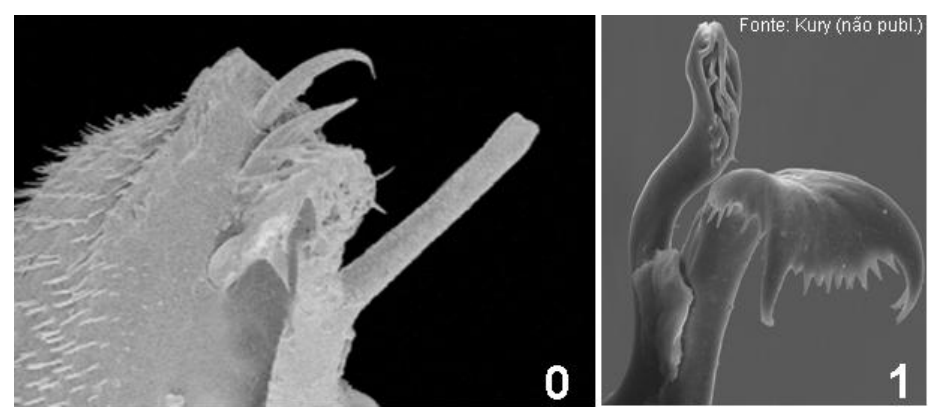

49 de Yamaguti \& Pinto-da-Rocha (2009). O formato do estilo reto (0) é plesiomórfico. O estado "1" (sinuoso dorsal) é sinapomorfia homoplástica de Bourguyia albiornata e Mitobatula castanea+, com reversão em Mitobates triangulus para reto e o estado 2 (sinuoso ventral) é autapomorfia de Caelopygus elegans.

10. Estilo - forma do ápice:

$(\mathrm{L}=3 ; \mathrm{I} . \mathrm{C}=0.33 ; \mathrm{I} . \mathrm{R}=0.85)$

0. normal

1. inflado

Modificado do caráter 20 de Kury (1991d). O ápice do
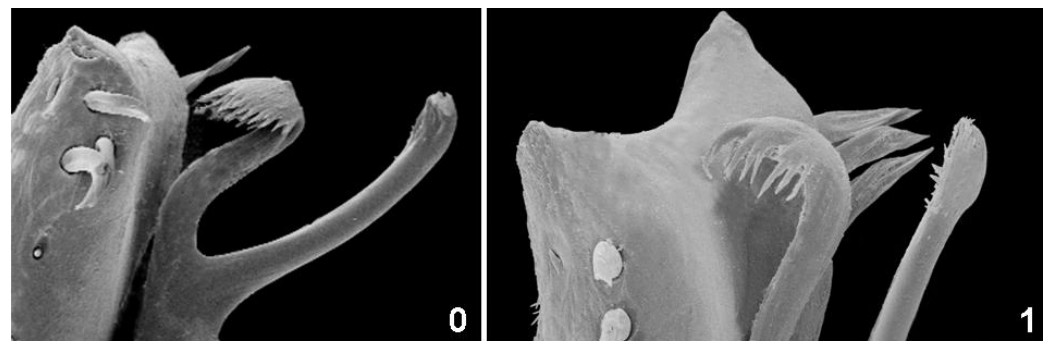

estilo inflado é sinapomorfia homoplástica dos clados Promitobates e Encheiridium ruschii + (Encheiridium + Metamitobates + Ruschia + Mitobatula + Mitobates), ocorrendo também em Discocyrtoides nigricans.

\section{Processo dorsal:}

$(\mathrm{L}=2 ; \mathrm{I} . \mathrm{C}=0.5 ; \mathrm{I} \cdot \mathrm{R}=0)$

0. presente

1. ausente 
Equivale ao caráter 8 de Kury (1994). Segundo Kury (1994), a presença de um processo dorsal (0) é plesiomórfico em Gonyleptidae, ocorrendo em Bourguyiinae e nas subfamílias mais basais, como Cobaniinae, sendo perdido nos demais Gonyleptidae derivados. Em Bourguyiinae, a perda do processo dorsal é apomórfico em algumas espécies de Asarcus e em Bourguyia laevibuna (Yamaguti \& Pinto-da-Rocha, 2009). Nesta análise, a presença de processo dorsal é plesiomórfico e a sua perda (1) é sinapomorfia do clado Pachylus chilensis+, com reversão em $B$. albiornata.

\section{Processo ventral - presença:}

$(\mathrm{L}=1 ; \mathrm{I} . \mathrm{C}=1.0 ; \mathrm{I} . \mathrm{R}=1.0)$

0. ausente

1. presente

Equivale ao caráter 7 de Kury (1994). Segundo Kury (1994), a ausência de um processo ventral (0) é plesiomórfico dentro de Gonyleptidae, tendo surgido em Bourguyiinae e nos demais Gonyleptidae derivados. Os resultados do presente estudo corroboraram a hipótese proposta por Kury (1994), onde a presença de um processo ventral (1) apareceu como sinapomorfia para o clado Bourguyia albiornata+

\section{Processo ventral - tamanho:}

$$
(\mathrm{L}=2 ; \mathrm{I} . \mathrm{C}=0.5 ; \mathrm{I} . \mathrm{R}=0.9)
$$

0 longo (maior ou igual ao estilo)

1. $\quad$ curto (menor que estilo)

O processo ventral menor que o estilo plesiomórfico dentro de Gonyleptidae,
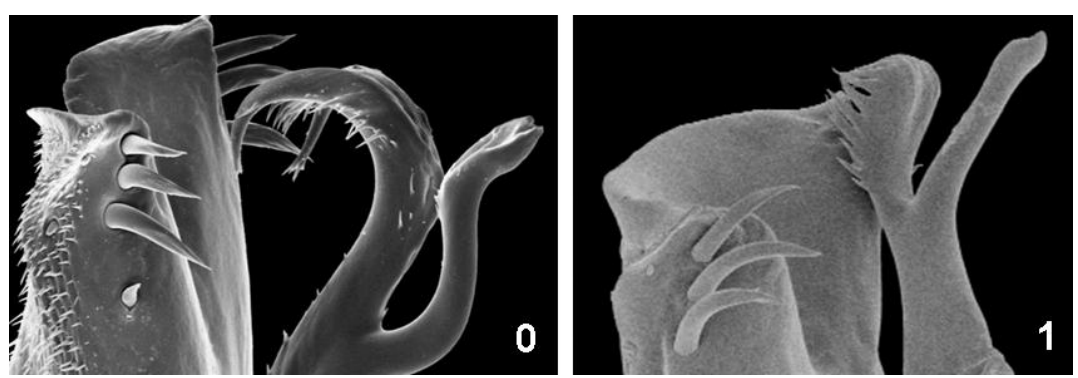
alongando-se (0) no clado (Caelopygus elegans $+D$. testudineus)+. A reversão para processo ventral curto ocorre como sinapomorfia homoplástica de Promitobates. 
14. Processo ventral:

$(\mathrm{L}=1 ; \mathrm{I} . \mathrm{C}=1.0 ; \mathrm{I} . \mathrm{R}=1.0)$

0. sem haste

1. com haste

A ausência de haste (0) é plesiomórfico dentro de Gonyleptidae, a presença é sinapomorfia de $B$. albiornata+.
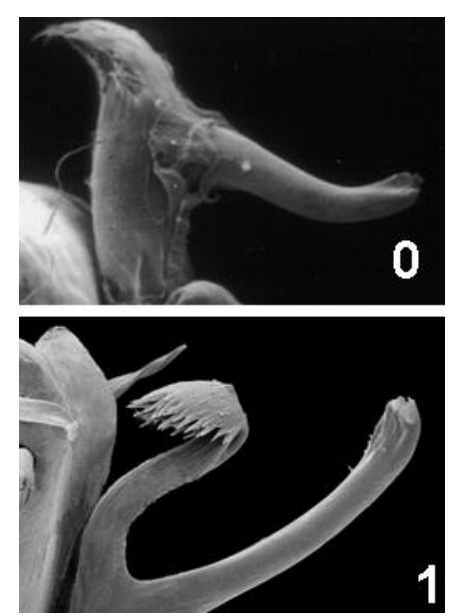

15. Ápice do processo ventral ("leque") - formato:

$(L=5 ; I . C=0.60 ; I . R=0.66)$

0. largo

1. estreito

2. muito estreito

3. tri-partido

Modificado do caráter 19 de Kury (1991). O estado "0", plesiomórfico, ocorre de forma independente em Bourguyia albiornata, Metamitobates squalidus e no clado Mitobates inermis+. A mudança para um leque estreito (1) ocorre no clado Pachylus chilensist. O estado 2 (leque muito estreito) é sinapomorfia de Neoancistrotus e o estado 3 (leque tripartido) é autapomorfia de Despirus parvulus.
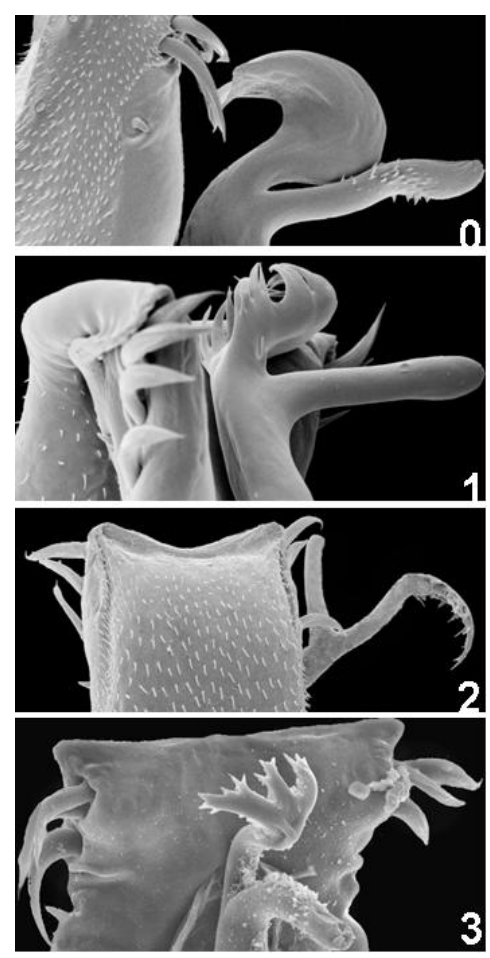

16. Ápice do processo ventral ("leque") - estrutura filamentosa nas bordas laterais ("franjas"):

$(\mathrm{L}=1 ; \mathrm{I} . \mathrm{C}=1.0 ; \mathrm{I} \cdot \mathrm{R}=1.0)$ 
0. ausente

1. presente

Modificado do caráter 19 de Kury (1991d). O estado plesiomórfico é a presença de "franjas" (1). A ausência dessas estruturas filamentosas (0) é sinapomorfia de Mitobates.

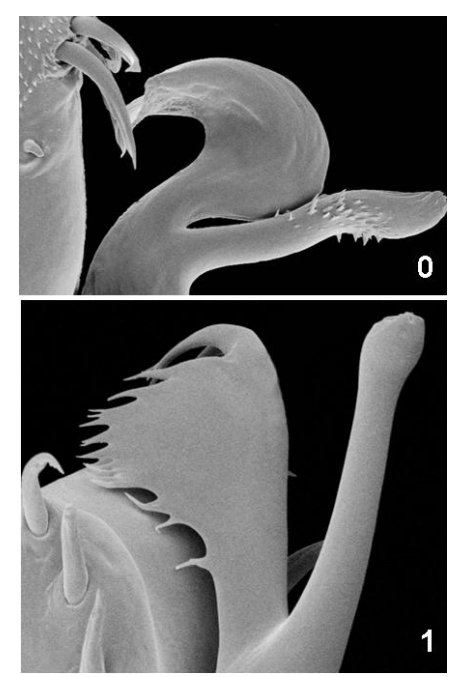

17. Ápice do processo ventral - orientação dos filamentos:

$(\mathrm{L}=1 ; \mathrm{I} . \mathrm{C}=1.0 ; \mathrm{I} . \mathrm{R}=1.0)$

0. Para os lados

1. para baixo (formato colher)

Modificado do caráter 19 de Kury (1991d). A orientação dos filamentos do leque do processo ventral é bastante
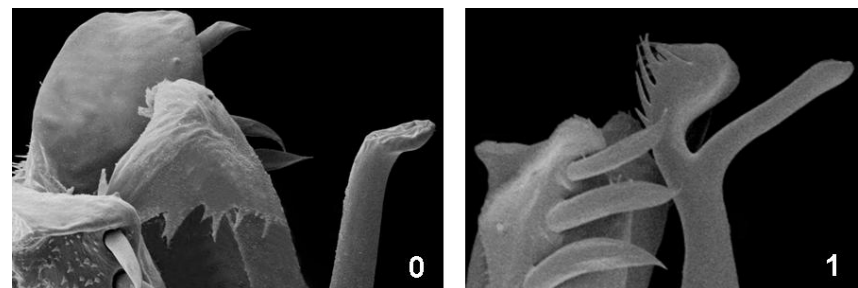
variável dentro dos Gonyleptidae que possuem processo ventral, mas de maneira geral, são voltadas para os lados (0). As "franjas" voltadas para baixo, bastante cerradas, deixando o ápice do processo ventral em formato cocleariforme (1) é sinapomorfia de Promitobates.

\section{8. Ângulo entre processo ventral e estilo:}

$(\mathrm{L}=4 ; \mathrm{I} . \mathrm{C}=0.5 ; \mathrm{I} . \mathrm{R}=0.87)$

0. quase $180^{\circ}$

1. menor que $90^{\circ}$

2. quase paralelos

O estado plesiomórfico é o processo ventral e o estilo formarem um ângulo de quase $180^{\circ}$. Um ângulo menor, menos de $90^{\circ}$ (1) é encontrado no clado $B$. 
albiornata+. Por outro lado, um ângulo muito pequeno, onde o estilo e o processo ventral se encontram quase paralelos, ocorre de maneira independente três vezes, sendo sinapomorfia de Mitobatula+ Mitobates e dos gêneros Ischnotherus e Promitobates.
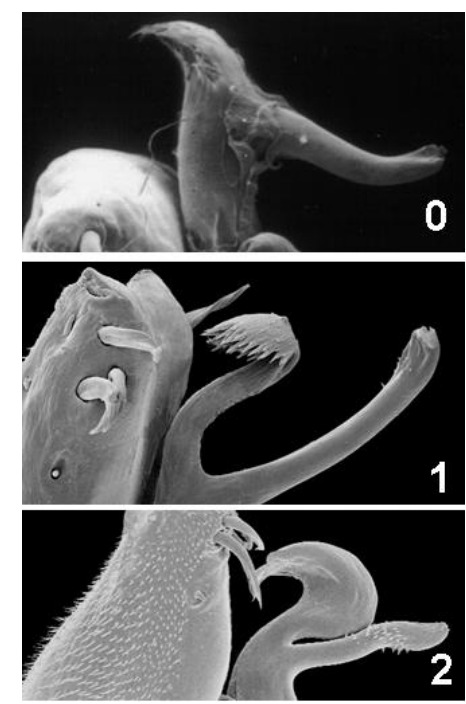

19. Tronco - posição do ápice em relação à placa ventral:

$(\mathrm{L}=5 ; \mathrm{I} . \mathrm{C}=0.40 ; \mathrm{I} . \mathrm{R}=0.84)$

0. não invadindo a base da placa ventral

1. invadindo pouco a placa ventral

2. invadindo bastante a placa ventral

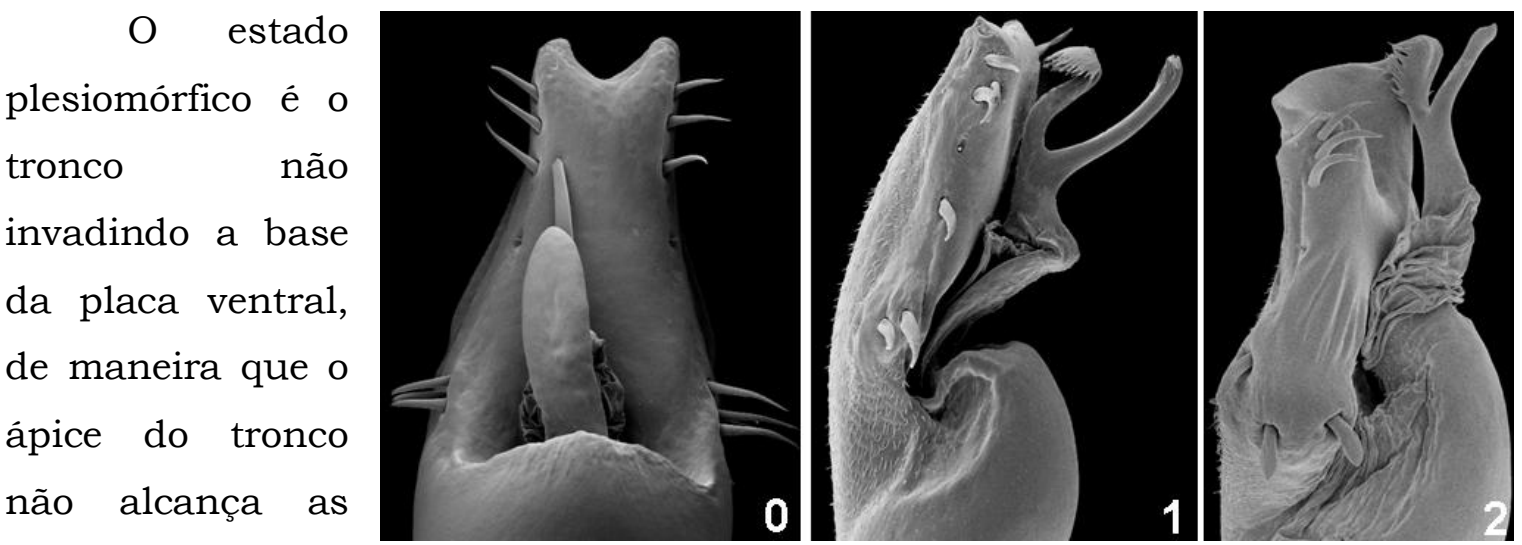
setas basais da placa ventral (0). O estado "1" onde tronco invade parte da placa ventral, alcançando as setas basais, mas não as ultrapassando, é sinapomorfia de Mitobatinae.. Em Promitobates, ocorre a mudança para o estado "2" , onde o tronco invade muito a placa ventral (ultrapassando as setas basais) ocorrendo também de forma homoplástica em Pachylus chilensis. 
20. Oculário - armação mediana :

$$
\begin{aligned}
& (\mathrm{L}=\text {; } \mathrm{I} . \mathrm{C}=1.0 ; \mathrm{I} \cdot \mathrm{R}=1.0) \\
& 0 . \quad \text { única } \\
& \text { 1. par }
\end{aligned}
$$

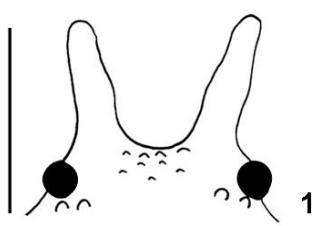

Modificado do caráter 7 de Pinto-da-Rocha (1997). A armação do oculário par é sinapomorfia de (Caelopygus elegans + Discocyrtus testudineus)+

\section{Oculário - armação par:}

$(\mathrm{L}=2 ; \mathrm{I} . \mathrm{C}=0.5 ; \mathrm{I} . \mathrm{R}=0$.)

0. tubérculos

1. apófises espiniformes

O estado plesiomórfico é a presença de apófises

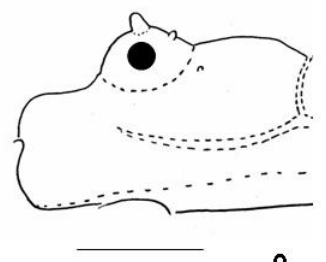
espiniformes (1) no oculário. A presença de tubérculos (1) ocorre de forma independente, como autapomorfia homoplastica nos táxons Caelopygus elegans e Promitobates sp.n1.

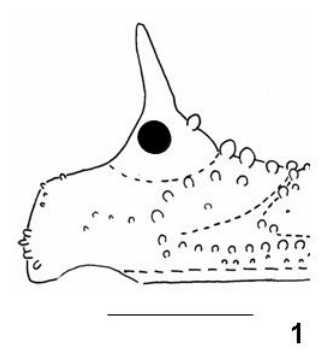

\section{Oculário - tubérculos na região anterior da armação:}

$(\mathrm{L}=5 ; \mathrm{I} . \mathrm{C}=0.20 ; \mathrm{I} . \mathrm{R}=0.71)$

0 . ausentes

1. presentes

O estado plesiomórfico é a ausência de tubérculos na

0

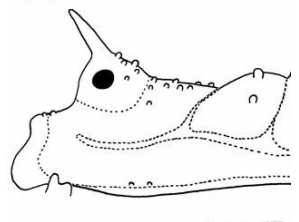
região anterior do oculário (0). O estado “1" (presença de tubérculos) é sinapomorfia homoplástica do clado Promitobates sp.n2+, ocorrendo também nos táxons Promitobates bellus, Longiperna cancellata, Longiperna

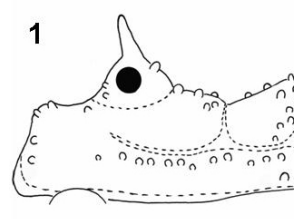


insperata e Borguyia albiornata.

23. Oculário - tubérculos na região posterior da armação :

$(\mathrm{L}=4 ; \mathrm{I} . \mathrm{C}=0.25 ; \mathrm{I} . \mathrm{R}=0.40)$

0 . ausente

1. presente

A presença de tubérculos na região posterior do oculário é plesiomórfica (1). A perda dos tubérculos (0) ocorre no clado Despirus parvulus+, com posterior reaquisição (1), em Metamitobates squalidus+ e no clado [2], formado por Discocyrtoides + Longiperna + Neoancistrotus + Promitobates.

\section{Prossoma - tubérculos em V atrás do oculário:}

$(L=3 ; \mathrm{I} . \mathrm{C}=0.33 ; \mathrm{I} . \mathrm{R}=0.85)$

0 . ausentes

1. presentes

O estado plesiomórfico é a ausência de tubérculos formando um

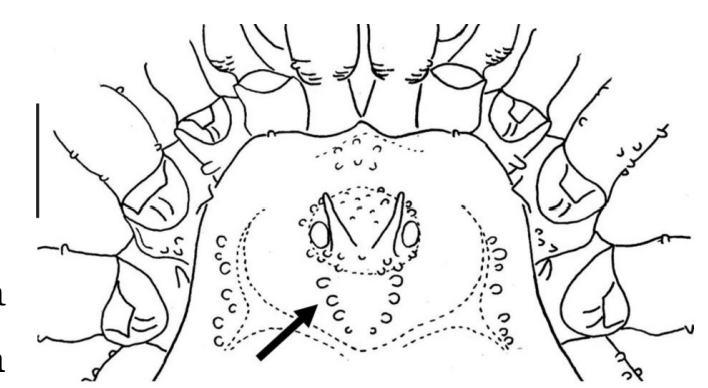
padrão definido abaixo do oculário, ou então esta região lisa (0). Tubérculos em fileiras longitudinais, formando uma semi-coroa ou um "V" abaixo do oculário (1) é sinapomorfia homoplástica de Promitobates, com reversão em Promitobates sp.n1 e de Mitobates pulcher + Mitobates triangulus.

25. Prossoma - Fileira longitudinal de tubérculos atrás do oculário: $(\mathrm{L}=1 ; \mathrm{I} . \mathrm{C}=1.0 ; \mathrm{I} . \mathrm{R}=1.0)$

0 . ausente 1. presente
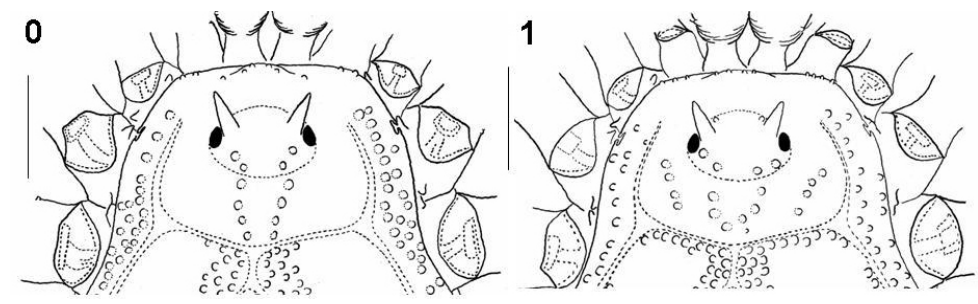
A presença de uma fileira longitudinal de tubérculos atrás do oculário, ao lado dos tubérculos em "V" (1) é autapomorfia homoplástica de Promitobates sp.n4. e P. viridigranulatus1.

\section{Escudo dorsal - largura (proporção prossoma - maior largura escudo):} $(L=3 ;$ I. $C=0.66 ; I . R=0.93)$

0. prossoma muito mais estreito que o abdômen (razão entre 0.40 a 0.50)

1. prossoma pouco mais estreito que o abdômen (razão entre 0.55 a 0.70)

2. prossoma e abdômen semelhantes (razão entre 0.75 a 0.85)

Modificado do caráter 3 de Pinto-da-Rocha (2002). O estado plesiomórfico é o prossoma muito mais estreito que o abdômen (0); esta diferença se torna menos evidente (1) em Despirus parvulus, e fica praticamente semelhante (2) no clado que agrupa Ischnotherus + Encheiridium + Metamitobates + Ruschia + Mitobatula + Mitobates (clado [1]). Uma única reversão é encontrada em Promitobates sp.n1, onde novamente o cefalotórax é muito mais estreito que o abdômen.

\section{Escudo dorsal - densidade de tubérculosna área II:}

$(\mathrm{L}=11 ; \mathrm{CI}=0.18 ; \mathrm{RI}=0.43)$

0 . baixa (menos de 10; tubérculos escassos)

1. média (poucas regiões das áreas lisas)

2. alta (quase totalmente recoberto por tubérculos)
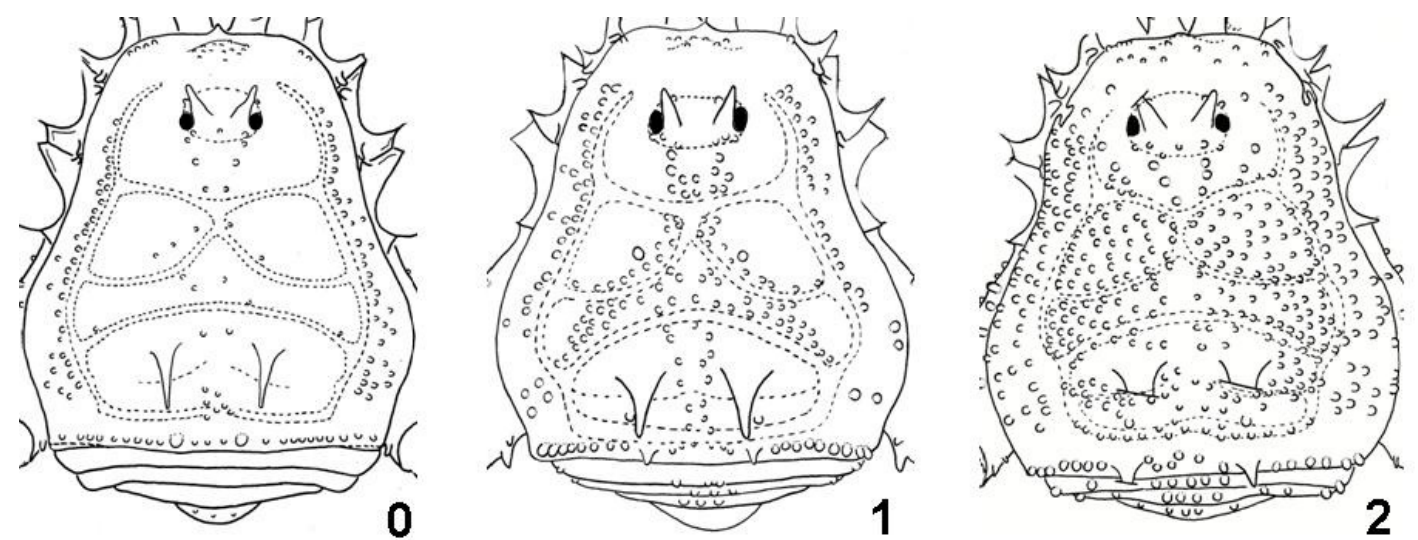
Este caráter mostrou-se bastante homoplástico e num primeiro momento, pareceu estar relacionado à quantidade de tubérculos das áreas III e IV. Entretanto, analisando a distribuição nos terminais, verificou-se que há espécies que apresentavam a área II com uma densidade de tubérculos bem maior que as demais áreas, e que o padrão de distribuição dos tubérculos nessas regiões do corpo eram bastante diferenciadas, apresentando sinal filogenético.

O estado plesiomórfico é a área II com densidade média de tubéculos (1). No clado Bourguyia albiornata+, passa a ser quase liso, com reversão em Caelopygus elegans. Em Mitobatinae, essa mudança ocorre nos clados Mitobatula castanea + Mitobates e no clado [2], Figura 2), com reversão em Neoancistrotus gracilis e Promitobates bellus.A área II do escudo dorsal praticamente coberto de tubérculos (3) ocorre de maneira independente em Metamitobates squalidus, Discocyrtoides nigricans, Longiperna coxalis, Promitobates sp.n3+Promitobates viridigranulatus e em Promitobates sp.n4.

\section{Escudo dorsal - distribuição dos tubérculos na área I:}

$(\mathrm{L}=1 ; \mathrm{I} . \mathrm{C}=1.0 ; \mathrm{I} . \mathrm{R}=1.0)$

0 . homogênea

1. mais concentrados próximos ao sulco posterior

2. circundando a área
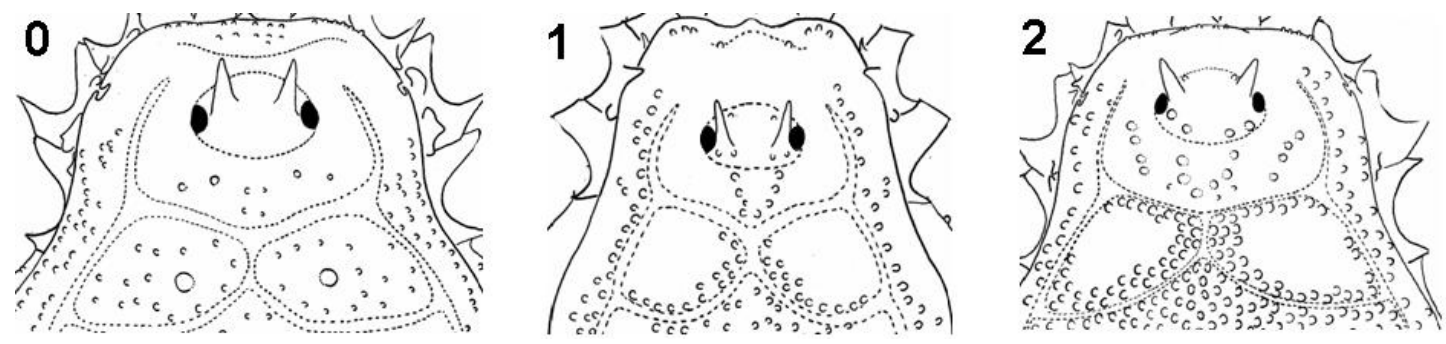

A distribuição homogênea dos tubérculos na área I (0) é o estado plesiomórfico. O estado "1", com os tubérculos concentrados próximos ao sulco posterior da área é sinapomorfia do clado Promitobates sp.n3+ e o estado "2", onde os tubérculos circundam a área é autapomorfia de Promitobates sp.n4

29. Escudo dorsal - áreas III-IV:

$(\mathrm{L}=12 ; \mathrm{I} . \mathrm{C}=0.16 ; \mathrm{I} \cdot \mathrm{R}=0.50)$ 
0. totalmente fundidas

1. parcialmente separadas

2. totalmente separadas
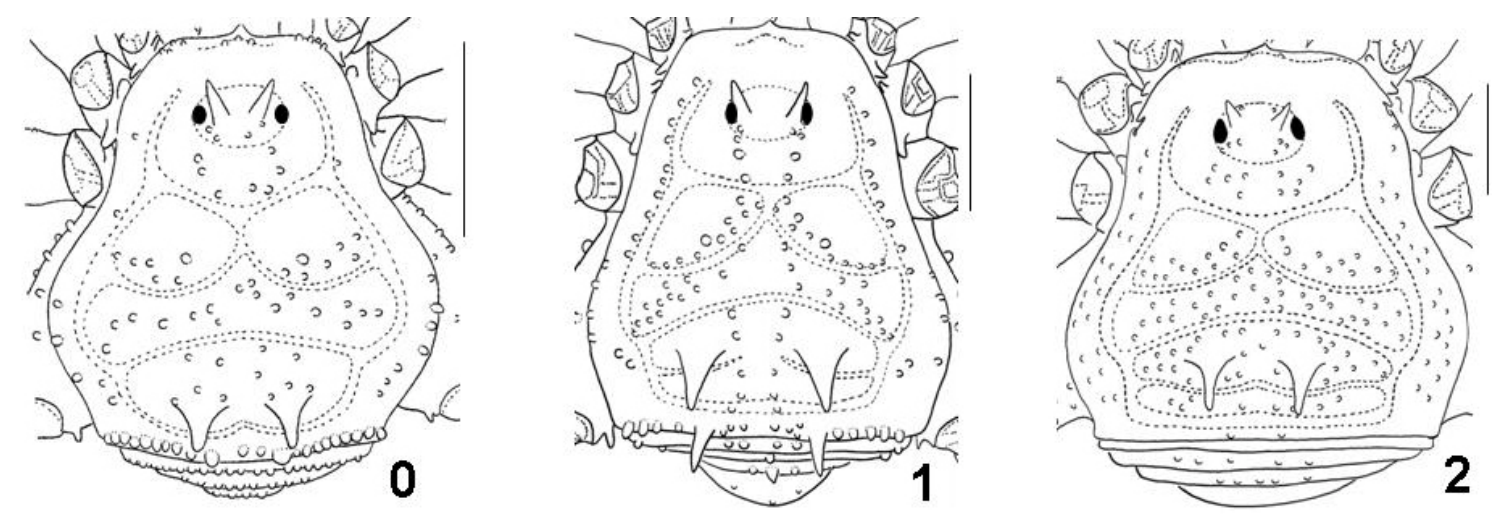

Modificado do caráter 3 de Kury (1991d), mostrou-se bastante homoplástico e de dificil visualização. Em animais com alta concentração de tubérculos, a visualização é bastante dificil, assim como em exemplares antigos, despigmentados. Muitas vezes, a distinção entre parcialmente e totalmente separadas só foi possivel com o exemplar seco, e nesses caso, a presença de mancha seca também pode dificultar a visualização. Portanto, este caráter deve ser considerado com cautela, mas uma vez que apresentou sinais filogenéticos e foi importante para a resolução de alguns clados, por isso foi mantido na análise.

As áreas III e IV totalmente separadas (2) é plesiomórfica para Mitobatinae (e compartilhada homoplasticamente em Ruschia vellutina, Promitobates ornatus1+, Promitobates sp.n3 e Promitobates hatschbachi); a mudança para o estado "1" - parcialmente separadas - ocorre no clado Encheiridium montanum+ (e compartilhada homoplasticamente pelo clado formado por Promitobates difficilis+ e no grupo-externo por Discocyrtus testudineus) e a mudança para o estado "O" - totalmente fundidas - é sinapomorfia do clado Neoancistrotus + Promitobates, compartilhada homoplasticamente no grupo-externo por Caelopygus elegans.

\section{Escudo dorsal - armação da área III:}

$(\mathrm{L}=5 ; \mathrm{I} . \mathrm{C}=0.40 ; \mathrm{I} . \mathrm{R}=0.40)$

0 . ausente

1. par de tubérculos

2. par de apófises altas espiniformes 
Modificado do caráter 14 de Kury (1994). Segundo Kury (1994), a presença de armação na área III é plesiomórfico dentro de Gonyleptidae. No presente estudo, a condição plesiomórfica foi a armação com um par de tubérculos (1). A mudança para um par de altas apófises espiniformes é sinapomorfia de Mitobatinae, com reversão em Ruschia vellutina. A ausência de armação (0) é autapomorfia de Mitobates inermis, no grupo-interno, e de Bourguyia albiornata, no grupo-externo.

31. Escudo dorsal - formato das apófises da área III:

$(\mathrm{L}=4 ; \mathrm{I} . \mathrm{C}=0.25 ; \mathrm{I} . \mathrm{R}=0.40)$

0. cilindricas

1. afiladas junto ao ápice

A apófise da área III afilada junto ao ápice (1) é derivado dentro de Mitobatinae e ocorre dentro de Promitobates como sinapomorfia do clado Promitobates sp.n1+, com reversão em $P$. viridigranulatus, $P$.
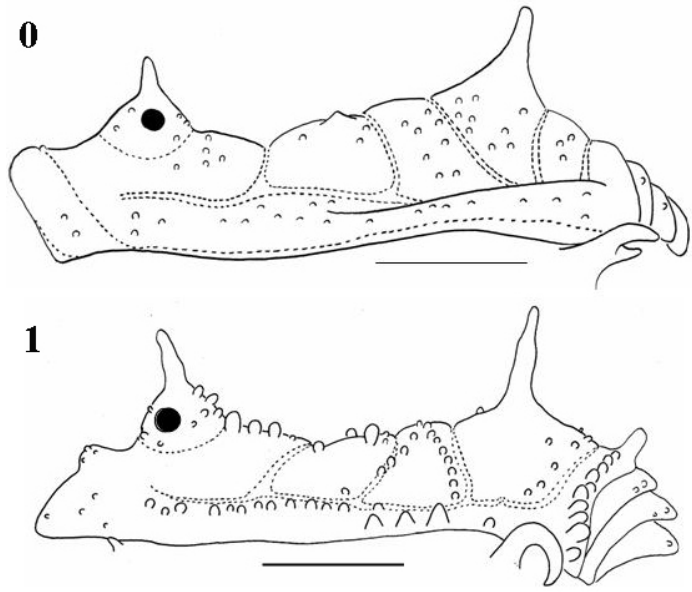
ornatus3 e no clado P. ornatus2+.

\section{Escudo dorsal - Tubérculos das áreas III-IV concentrados na região mediana (entre armação área III):}

$(\mathrm{L}=3$; I. $\mathrm{C}=0.33$; I.R= 0.80)

0. ausentes

1. presentes

Tubérculos das áreas III-IV concentrados verticalmente entre a armação da área III (1) é derivado dentro Mitobatinae e ocorre dentro
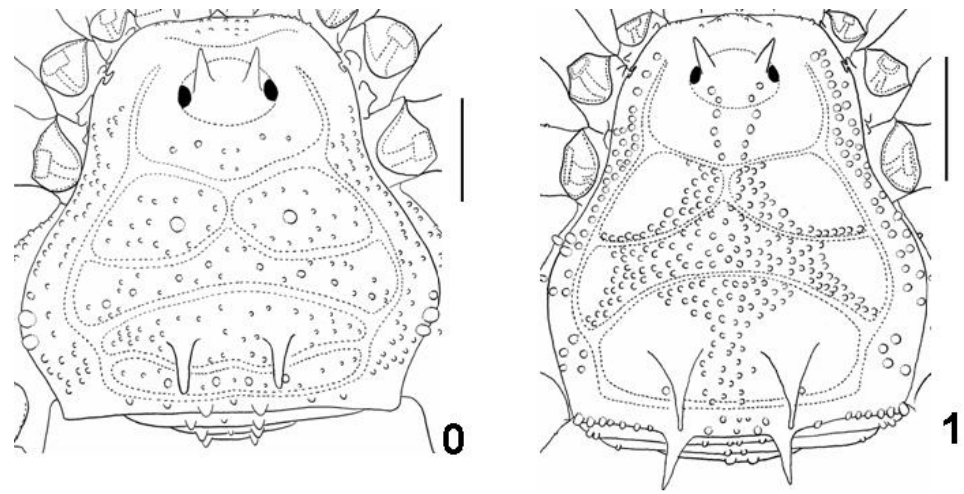
homoplasticamente em Neoancistrotus guapimirim), com reversão em Promitobates hatschbachi.

33. Escudo dorsal - área III totalmente preenchida por tubérculos:

$(\mathrm{L}=8 ; \mathrm{I} . \mathrm{C}=0.12 ; \mathrm{I} . \mathrm{R}=0.12)$

0 . presente

1. ausente

Caráter amplamente homoplástico, a área III totalmente recoberta de tubérculos (0) é derivada e ocorre independentemente em Bourguyia albiornata e Caelopygus elegans, no grupo-externo, e no grupo-
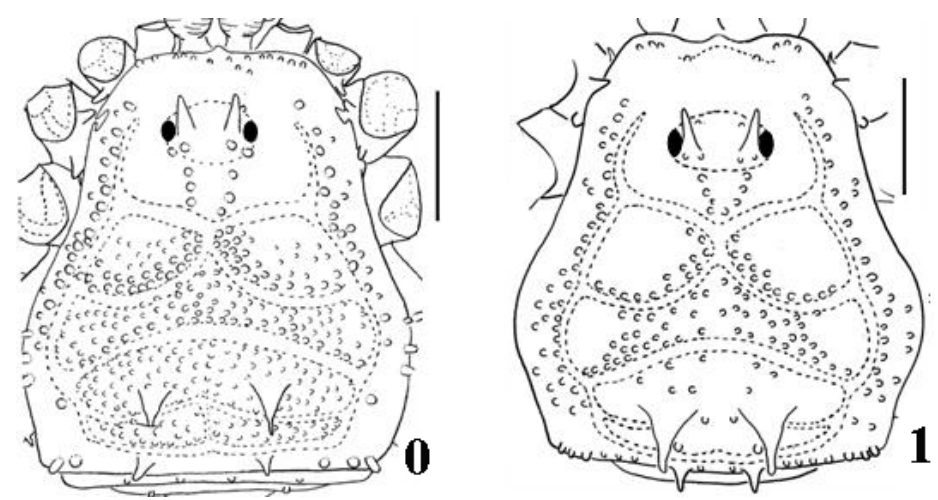

interno, como sinapomorfia de Longiperna (exceto L. concolor), em Neoancistrotus guapimirim, Promitobates spn3, P. viridigranulatus1 e P sp.n4.

34. Escudo dorsal - Fileira de tubérculos na margem área III:

$(\mathrm{L}=2 ; \mathrm{I} . \mathrm{C}=0.50 ; \mathrm{I} . \mathrm{R}=0.80)$

0. ausente

1. presente

A presença de uma fileira de tubérculos no sulco entre as áreas III-IV (1) é derivado em Mitobatinae e ocorre em Promitobates sp.n3+ e em Promitobates sp.n4+.
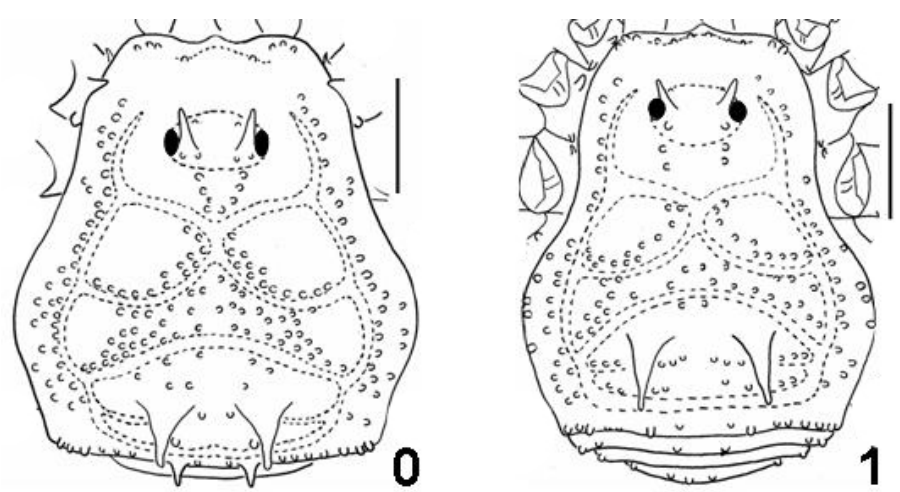
35. Escudo dorsal - área IV totalmente preenchida por tubérculos:

$(\mathrm{L}=2 ; \mathrm{I} . \mathrm{C}=0.5 ; \mathrm{I} \cdot \mathrm{R}=0)$

0. ausente

1. presente

A área

IV

totalmente preenchida

por tubérculos

(0)

sinapomorfia

de

Promitobates sp.n3 $+P$.

viridigranulatus 1 .
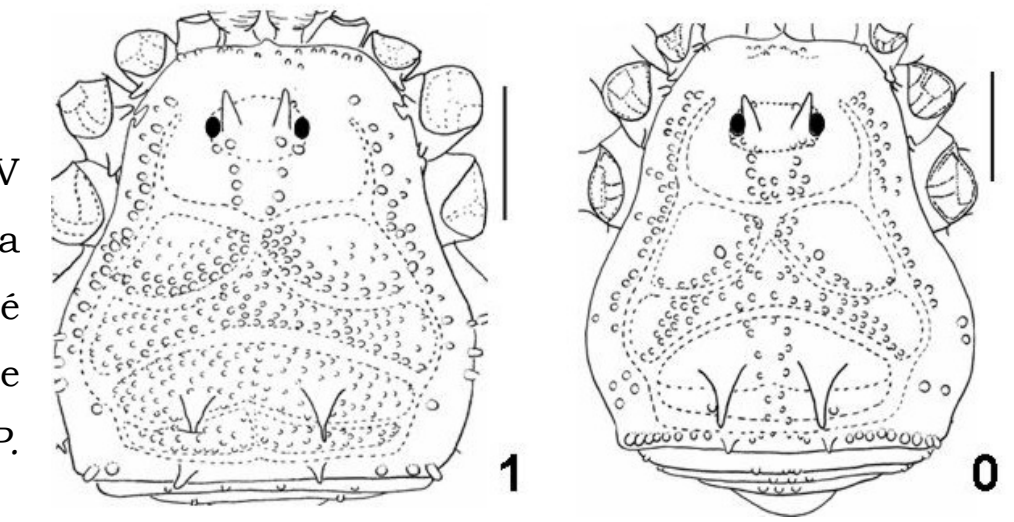

36. Escudo dorsal - Fileira de tubérculos na margem do sulco IV (espaço entre eles menor que tamanho):

$(\mathrm{L}=2 ; \mathrm{I} . \mathrm{C}=0.50 ; \mathrm{I} . \mathrm{R}=0.83)$

0. ausentes

1. presente

A presença de uma fileira de tubérculos junto ao sulco IV (1) do escudo dorsal é sinapomorfia homoplástica dos clados Promitobates sp.n3+ e de Promitobates ornatus2+.
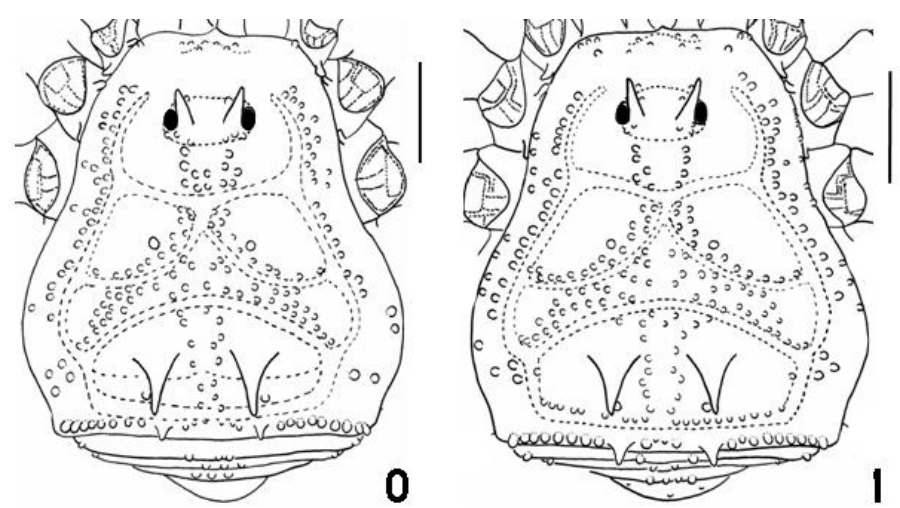

37. Escudo dorsal - armação área IV:

$(\mathrm{L}=7 ; \mathrm{I} . \mathrm{C}=0.28 ; \mathrm{I} . \mathrm{R}=0.72)$

0 . sem par de tubérculos proeminentes

1. com par de tubérculos proeminentes

2. com dois pares de tubérculos proeminentes 

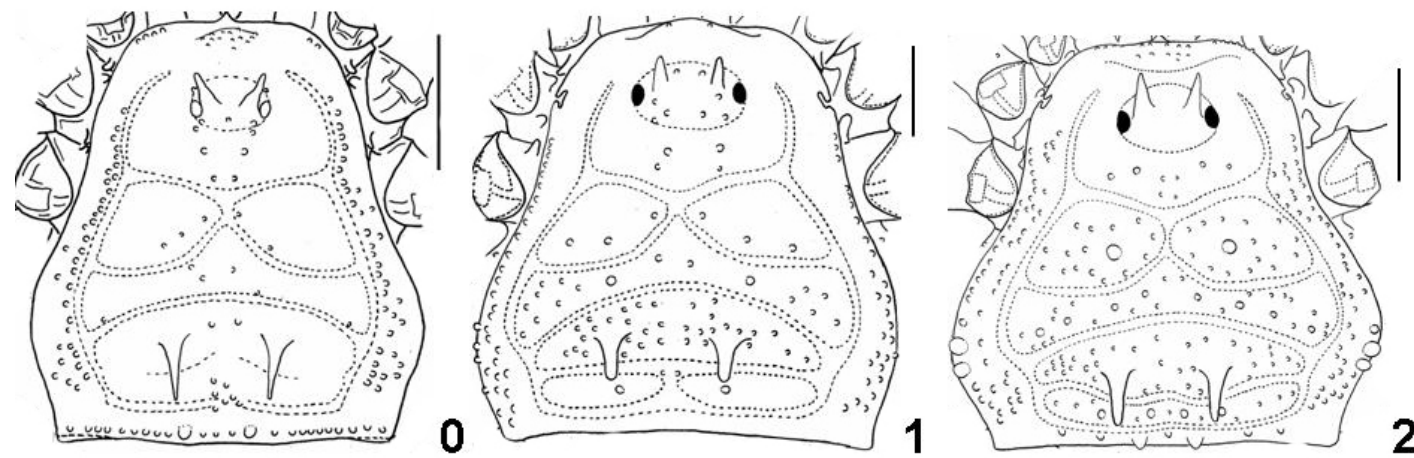

O estado plesiomórfico é a presença de um par de tubérculos na área IV (1). A mudança para dois pares de tubérculos ocorre de forma independente em Despirus parvulus, Longiperna coxalis e no clado Mitobatula castanea+. A mudança para a ausência de tubérculos na área IV (0) também ocorre de maneira homoplástica em Caelopygus elegans+, Encheiridium montanum+ e como sinapomorfia de Neoancistrotus + Promitobates, com reversão para o estado 1 no clado Promitobates sp.n2+.

\section{Escudo dorsal - armação da margem posterior :}

$(\mathrm{L}=8 ; \mathrm{I} . \mathrm{C}=0.25 ; \mathrm{I} . \mathrm{R}=0.62)$

0. inerme

1. par de tubérculos proeminentes (arredondados ou espiniformes)

2. par de altas apófises espiniformes
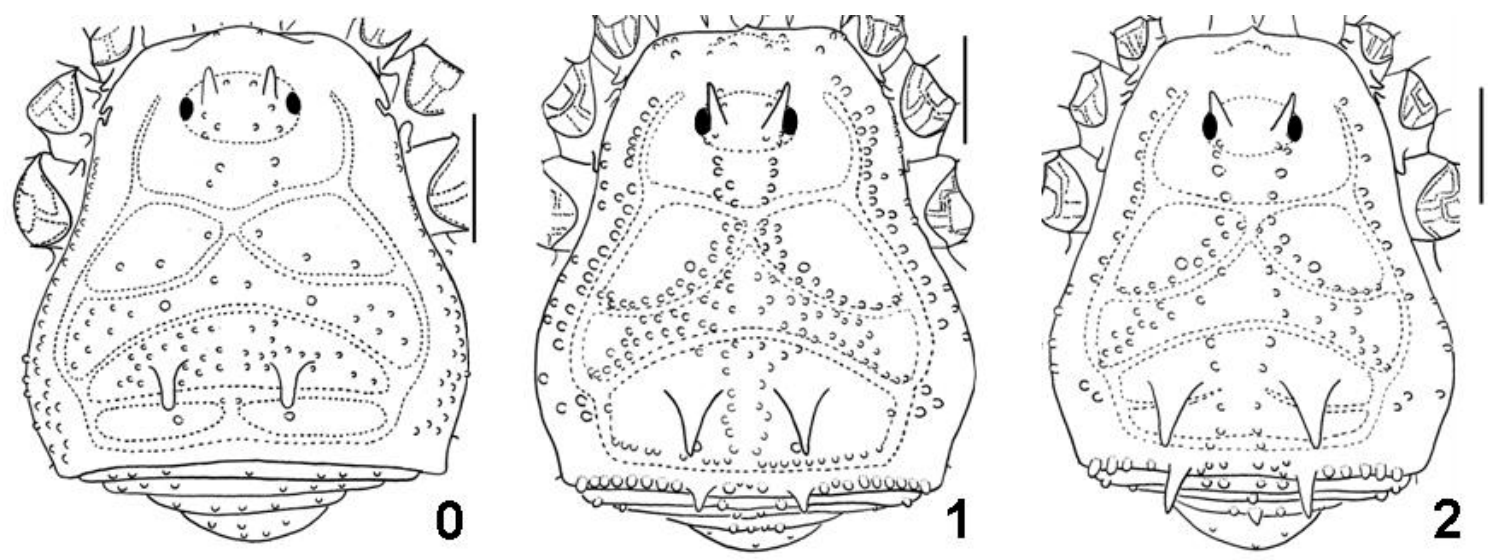
O estado plesiomórfico é a borda posterior inerme (0). A borda posterior armada com um par de tubérculos (1), definido como a largura da armação maior ou igual ao comprimento, ocorre de maneira independente em Ischnotherus tenebrosus, Mitobatula castanea, Longiperna coxalis, Neoancistrotus guapimirim e como sinapomorfia de Promitobates (com reversão em $P$. viridigranulatus). A presença de um par de altas apófises espiniformes na borda posterior (2), definido como largura da armação sempre menor que o comprimento, ocorre como autapomorfias homoplásticas de Promitobates ornatus3 e Promitobates hatschbachi.

\section{Escudo dorsal - fileira de tubérculos na margem posterior (espaço entre eles menor que tamanho):}

$(\mathrm{L}=5 ; \mathrm{I} . \mathrm{C}=0.20 ; \mathrm{I} . \mathrm{R}=0.69)$

0. ausente

1. presente

A presença de uma fileira de tubérculos na borda posterior (1) é sinapomorfia de Neoancistrotus + Promitobates (ocorrendo homoplasticamente
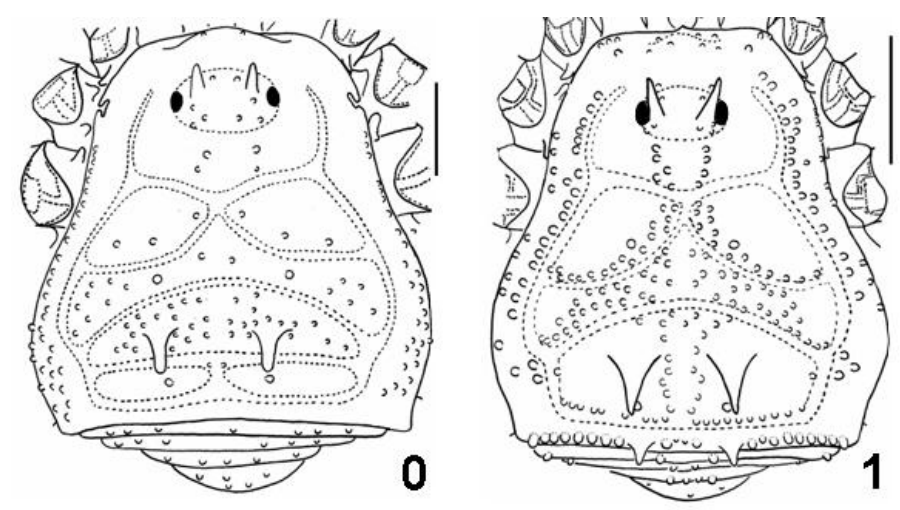
em Despirus parvulus), com reversões homoplásticas (0) em Neoancistrotus bipustulatus, Promitobates sp.n1 e P. hatschbachi.

40. Escudo dorsal - formato dos tubérculos da margem posterior: $(\mathrm{L}=2 ; \mathrm{I} . \mathrm{C}=0.50 ; \mathrm{I} . \mathrm{R}=0.66)$

0. isomórficos

1. maiores nas bordas

Caráter aplicável apenas aos táxons com fileiras de tubérculos na
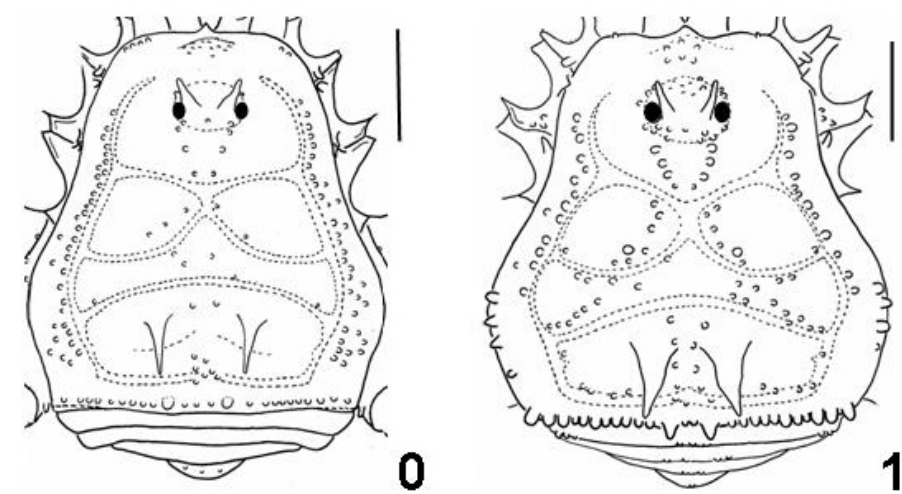
borda posterior (Despirus parvulus e Neoancistrotus + Promitobates). O estado plesiomórfico são tubérculos regulares (0) em toda a borda posterior, se tornando maiores próximos à margem lateral (1) no clado Promitobates sp.n1+.

\section{Tergitos livres - Margem lateral do tergito livre I com tubérculo proeminente:}

$(\mathrm{L}=2 ; \mathrm{I} . \mathrm{C}=0.50 ; \mathrm{I} . \mathrm{R}=0.91)$

0. ausente

1. presente

O estado plesiomórfico é o tergito livre I liso (0) ou com uma fileira regular de tubérculos. O tergito livre I com um tubérculo destacado na margem lateral (1) é
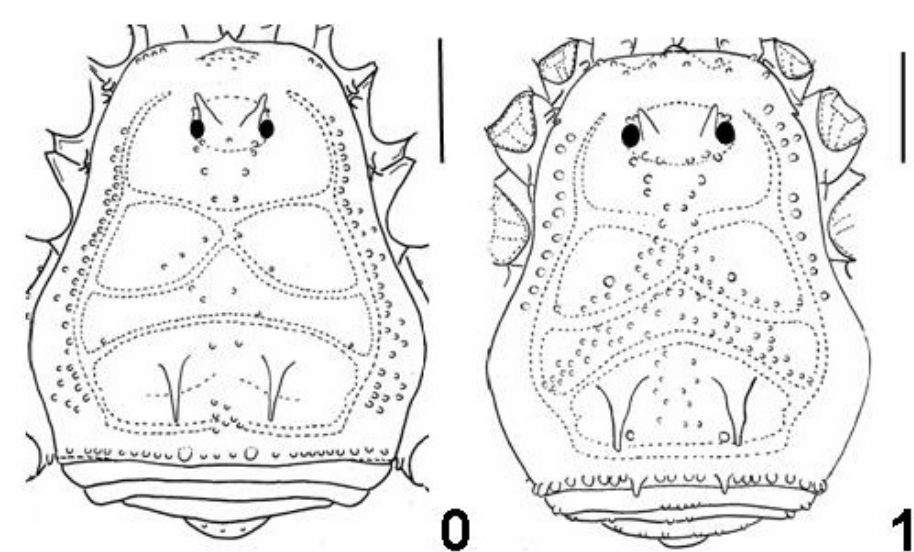

sinapomorfia de Promitobates viridigranulatus+.

42. Tergitos livres - Armação no tergito livre II:

$(\mathrm{L}=2 ; \mathrm{I} . \mathrm{C}=0.50 ; \mathrm{I} . \mathrm{R}=0.0)$

0 inerme

1. armação par mediana

A armação par no tergito livre II (1), com tubérculos espiniformes, é autapomorfia homoplástica de Longiperna coxalis e Promitobates sp.n1.
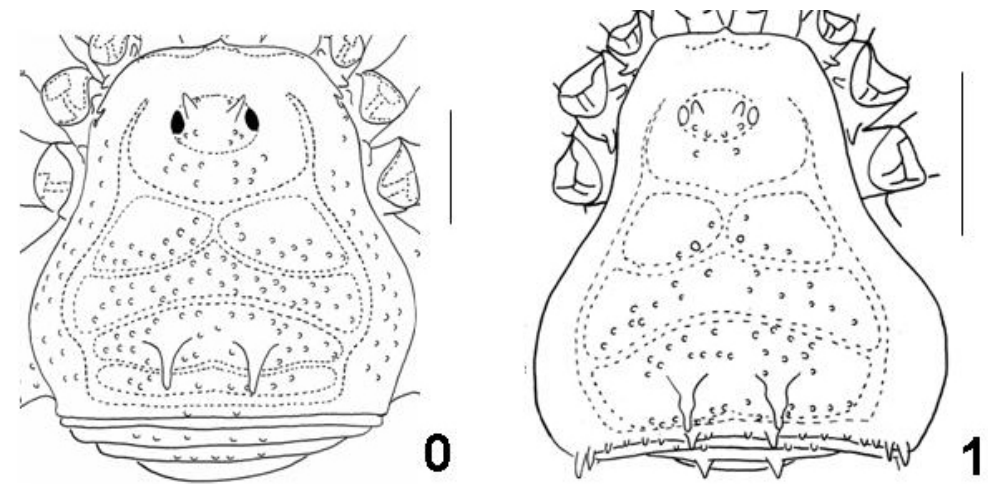


\section{Tergitos livres - armação no tergito livre III:}

$(L=3 ; \mathrm{I} . \mathrm{C}=0.33 ; \mathrm{I} . \mathrm{R}=0.33)$

0 . tergito livre III inerme

1. tergito livre III com armação mediana

Modificado do caráter 9 de Kury (1994). A armação impar no tergito livre III (1), com tubérculos espiniformes ou arredondados, mas sempre maiores que os demais tubérculos dos tergitos; é autapomorfia homoplástica de Promitobates
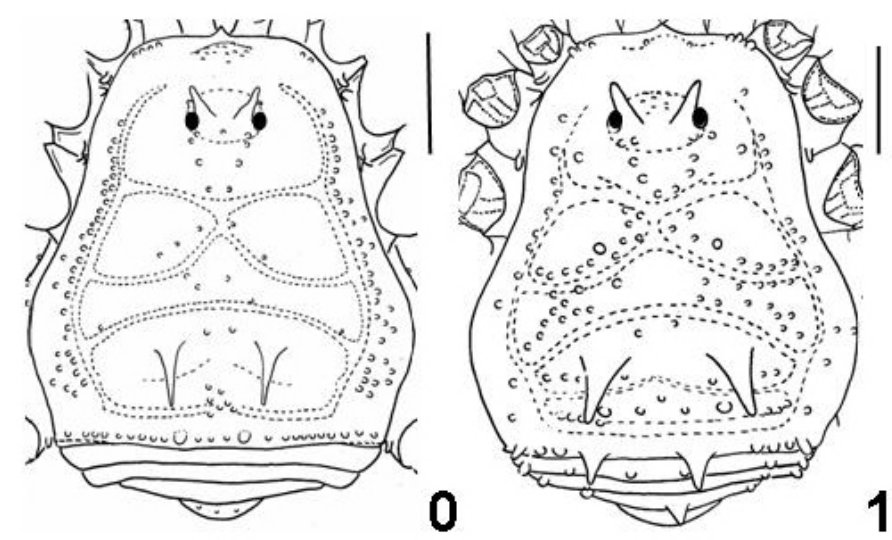
ornatus 3+4, P. sp.n2 e P. hatschbachi 2.

\section{APÊNDICES}

44. Pedipalpo - espessura (fêmur maior que a metade do comprimento): $(\mathrm{L}=4$; I.C $=0.25 ; \mathrm{I} . \mathrm{R}=0.78)$

0. robusto

1. delgado

Modificado do caráter 4 de Kury (1991). O estado plesiomórfico é o pedipalpo de espessura robusta (0). A mudança para pedipalpo delgado (1) no grupo-interno é sinapomorfia homoplástica dos clados Ruschia vellutina+ e Promitobates. No grupo-externo, o pedipalpo delgado é encontrado homoplasticamente em Bourguyia albiornata+, com reversão em Despirus parvulus+.

\section{Pedipalpo - seta distal mesal do fêmur:}

$(\mathrm{L}=1 ; \mathrm{I} . \mathrm{C}=1.0 ; \mathrm{I} . \mathrm{R}=1.0)$ 
0. ausente

1. presente

Modificado do caráter 16 de Pinto-da-Rocha (2002); equivale ao caráter 22 de Yamaguti \& Pinto-da-Rocha (2009). O estado plesiomórfico é a ausência da seta distal do fêmur do pedipalpo (0). A presença da seta distal mesal (1) é sinapomorfia do clado Bourguyia albiornata+.

46. Coxa IV dos machos - região distal ultrapassando a borda do escudo dorsal:

$(\mathrm{L}=3 ; \mathrm{I} . \mathrm{C}=0.33 ; \mathrm{I} . \mathrm{R}=0.83)$

0 . não ultrapassando

1. ultrapassando

O estado plesiomórfico é a coxa IV menor que o comprimento
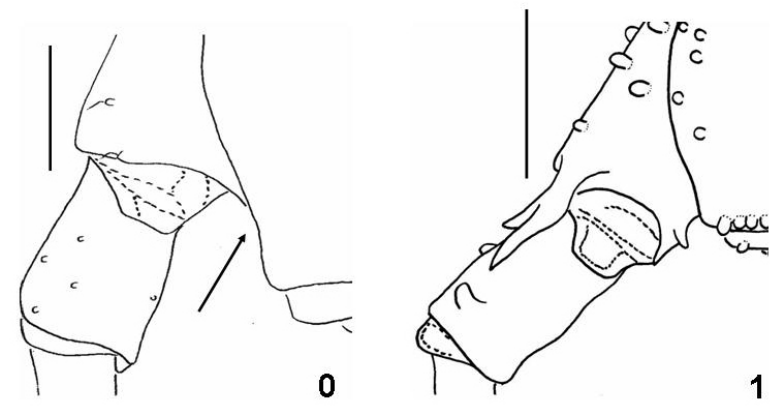

do escudo dorsal (0). A mudança para igual ou maior (1) ocorre em em Pachylus chilensis+ (compartilhada homoplasticamente pelo clado [2] (Discocyrtoides + Longiperna + Neoancistrotus + Promitobates). com reversão (0) em D. parvulus+.

\section{Coxa IV dos machos - extremidade interna:}

$(\mathrm{L}=3 ; \mathrm{I} . \mathrm{C}=0.33 ; \mathrm{I} . \mathrm{R}=0.85)$

0. não ou pouco visivel dorsalmente

1. muito visível dorsalmente

A extremidade interna da
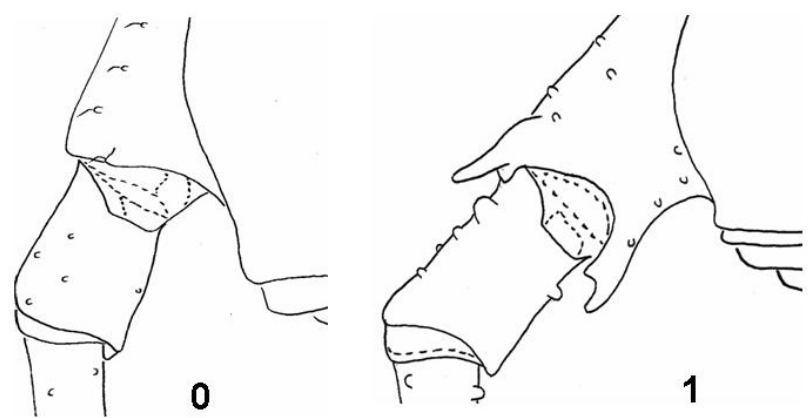

coxa IV muito visível em vista dorsal (1) é sinapomorfia do clado [2], formado por Discocyrtoides + Longiperna + Neoancistrotus + Promitobates. No grupo-externo, é compartilhado homoplasticamente por Borguyia albiornata e Caelopygus elegans. 


\section{Coxa IV dos machos - Apófise externa:}

$(L=2 ; \mathrm{I} . \mathrm{C}=0.50 ; \mathrm{I} . \mathrm{R}=0.87)$

0 . ausente

1. presente

A presença de apófise externa na coxa IV (1) é plesiomórfica. A perda da armação (0) ocorre com sinapomorfia homoplástica de Ischnotherus e do clado Metamitobates squalidus+.
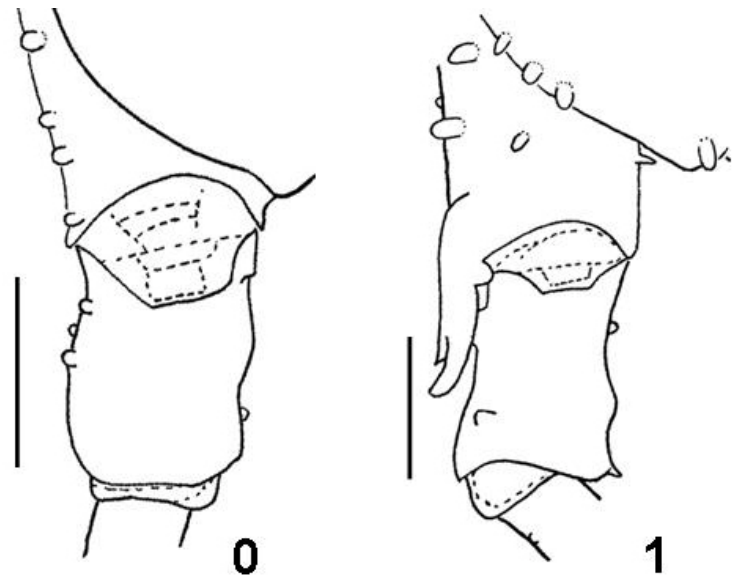

49. Coxa IV dos machos - apófise apical externa :

$(\mathrm{L}=5 ; \mathrm{I} . \mathrm{C}=0.20 ; \mathrm{I} . \mathrm{R}=0.42)$

0. simples

1. bifurcada

Equivale ao caráter 6 de Kury (1994). Segundo Kury (1994), a apófise simples da coxa IV é plesiomórfica, ocorrendo em Cosmetidae, Metasarcinae,
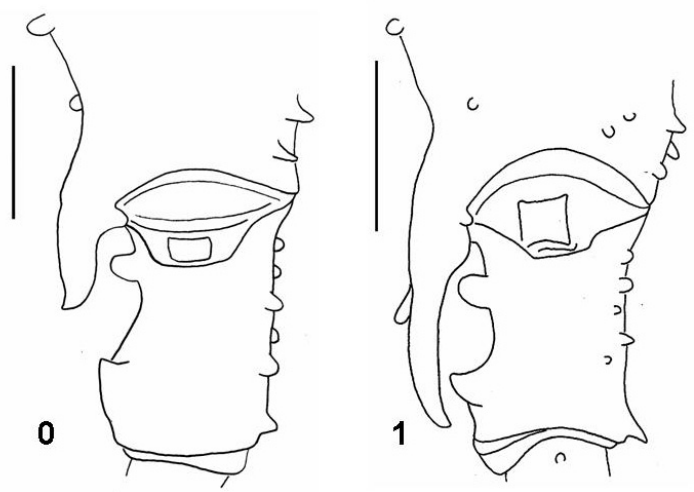

Heteropachylinae e Cobaniinae. A presença de uma apófise bífida ocorre em Bourguyiinae e nos outros Gonyleptidae.

A evolução desse caráter depende de otimização. Optando-se por ACCTRAN, no grupo-externo, a mudança para apófise bífida (1) ocorre em Pachylus chilensis+, com reversão em (Caelopygus elegans+ D. testudineus). Em Mitobatinae, a presença de apófise bífida é sinapomorfia de [2] (Discocyrtoides + Longiperna + Neoancistrotus + Promitobates), com reversão homoplástica em Promitobates sp.n1 e P. sp.n2. Optando-se por otimização DELTRAN, a presença de apófise bífida é sinapomorfia de [2] (Discocyrtoides + Longiperna + Neoancistrotus + Promitobates) (com reversão homoplástica em Promitobates sp.n1 e $P$. sp.n2) e, no grupo-externo, ocorre homoplasticamente em B. albiornata e P. chilensis. 
50. Coxa IV dos machos - tamanho dos ramos da apófise bifida externa :

$(\mathrm{L}=2 ; \mathrm{I} . \mathrm{C}=0.50 ; \mathrm{I} . \mathrm{R}=0)$

0. semelhantes

1. ramo dorsal maior

Caráter aplicável apenas aos táxons com apófise externa bífida. O estado plesiomórfico é o ramo dorsal maior (1). A
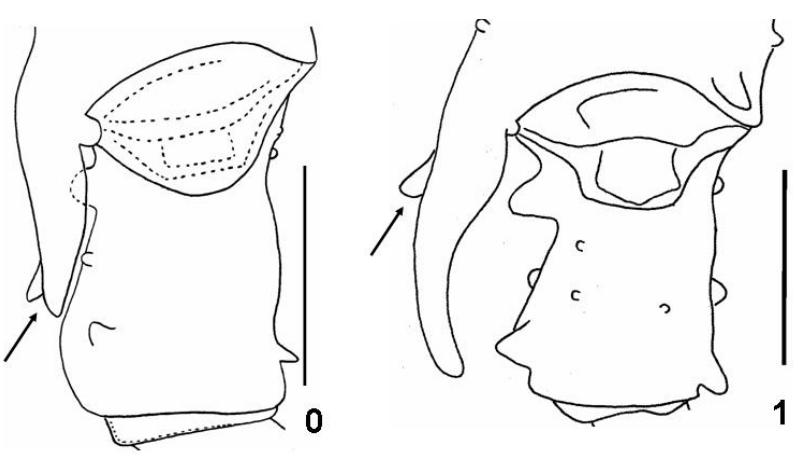
mudança para tamanhos semelhantes (0) ocorre homoplasticamente em Bourguyia albiornata e Promitobates sp.n3.

\section{Coxa IV dos machos - forma da apófise externa :}

$(\mathrm{L}=2 ; \mathrm{I} . \mathrm{C}=0.50 ; \mathrm{I} . \mathrm{R}=0.50)$

0 . reta (com ápice voltado para baixo)

1. voltada para baixo

Modificado do caráter 19 de Pinto-da-Rocha (2002). A apófise externa da coxa IV dos machos reta é plesiomórfica. A mudança ocorre em Bourguyia albiornata, com reversão em Caelopygus elegans + Discocyrtus testudineus.

\section{Coxa IV dos machos - comprimento da apófise externa :}

$(\mathrm{L}=8 ; \mathrm{I} . \mathrm{C}=0.37 ; \mathrm{I} . \mathrm{R}=84)$

0. ausente

1. muito reduzida (espiniforme)

2. curta (menor que o comprimento do trocânter)

3. longa (semelhante ou maior que o comprimento do trocânter)

O estado plesiomórfico é a apófise externa longa (3). Muda para curta (2) em Bourguyia albiornata+ (com reversões homoplásticas para longa em Caelopygus elegans, Longiperna coxalis, no gênero Neoancistrotus e no clado Promitobates difficilis+), para reduzida (1) no clado [1] de Mitobatinae e torna-se ausente (0) no gênero Ischnotherus e Metamitobates squalidus+. 
53. Coxa IV dos machos - Tubérculo dorsal na base da apófise externa :

$(\mathrm{L}=2 ; \mathrm{I} . \mathrm{C}=0.50 ; \mathrm{I} . \mathrm{R}=0.80)$

0. ausente

1. presente

Modificado do caráter 20 de Pinto-da-Rocha (2002). A presença de um tubérculo na base da apófise externa da coxa IV (1) é sinapomorfia do clado Promitobates sp.n3+, com
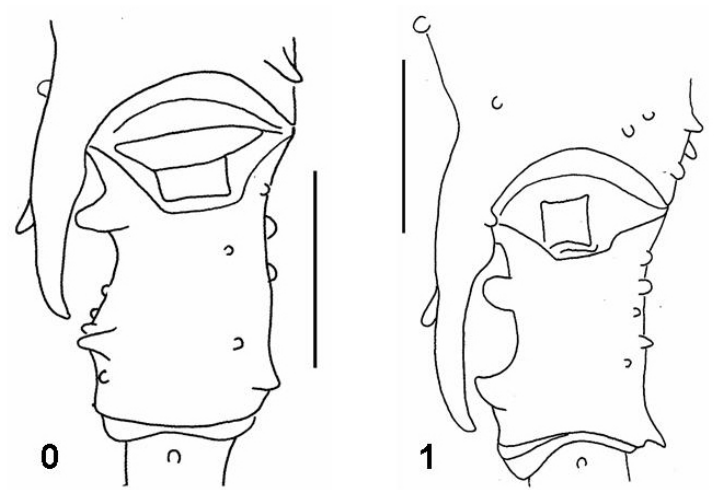

perda em Promitobates ornatus1+.

54. Coxa IV dos machos - Apófise interna :

$(\mathrm{L}=2 ; \mathrm{I} . \mathrm{C}=0.50 ; \mathrm{I} . \mathrm{R}=0.90)$

0. ausente

1. presente

Modificado do caráter 22 de Pintoda-Rocha (2002). O estado plesiomórfico é a presença de uma apófise interna na coxa IV do macho (1). A perda dessa apófise (0) ocorre em Pachylus chilensis e

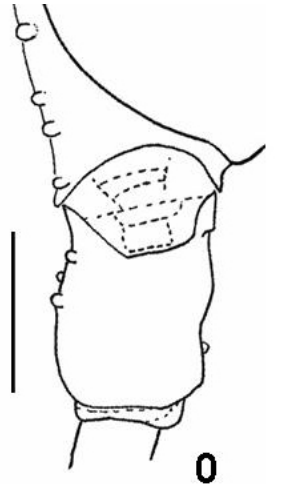
em Mitobatinae é sinapomorfia do clado [1] ).

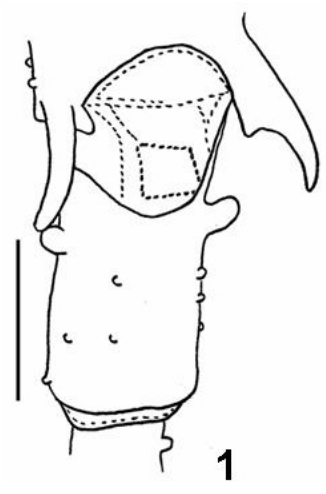

\section{Coxa IV dos machos - formato da apófise interna :}

$(\mathrm{L}=1 ; \mathrm{I} . \mathrm{C}=1.0 ; \mathrm{I} . \mathrm{R}=1.0)$

0 . espiniforme

1. bifurcada

Modificado do caráter 10 de Kury (1991). Este caráter só é aplicável aos táxons que possuem apófise interna da coxa IV. Em Mitobatinae, aplica-se
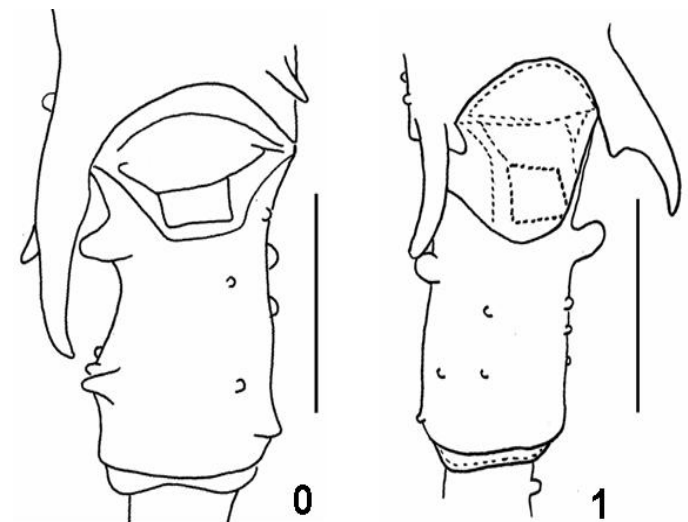
somente ao clado [2]. A presença de uma apófise interna bífida (1) é sinapomorfia de Discocyrtoides + Longiperna.

56. Coxa IV dos machos - tamanho da apófise interna:

$(\mathrm{L}=2 ; \mathrm{I} . \mathrm{C}=1.0 ; \mathrm{I} . \mathrm{R}=1.0)$

0. menor que a externa

1. tamanhos semelhantes

2. maior que a externa

Este caráter só é aplicável aos táxons que possuem apófise interna da coxa IV. Em Mitobatinae, aplica-se somente ao clado [2]. O
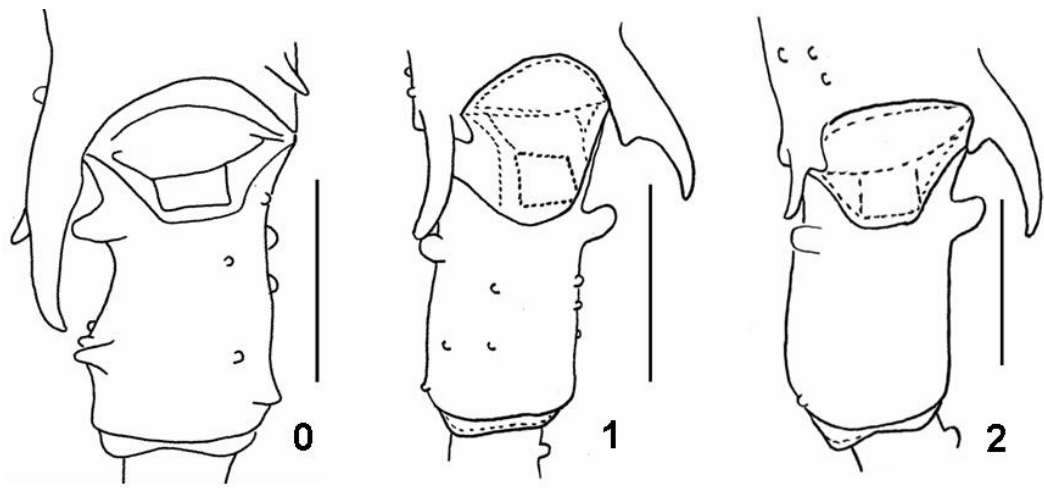

estado plesiomórfico é a apófise interna menor que a externa (0); a apófise interna de tamanho semelhante à externa (1) é sinapomorfia de Discocyrtoides + Longiperna e a apófise interna maior que a externa (2) é autapomorfia de Lomgiperna insperata.

\section{Trocânter IV do macho - formato:}

$(L=5 ; I . C=0.60 ; I . R=0.50)$

0. mais largo que longo (razão $<0.70$ )

1. tão largo quanto longo (razão de 0.98 a 1.01)

2. pouco mais longo que largo (razão de 1.10 a 1.80)

3. muito mais longo que largo (razão de $1.98 \mathrm{a}>2.0$ )

Modificado do caráter 33 de Yamaguti \& Pinto-da-Rocha (2009). O trocânter mais largo do que longo (0) é autapomorfia de Pachylus chilensis; o estado "1" - onde a largura e comprimento são semelhantes, é plesiomórfico e reversão em Caelopygus elegans. O trocânter mais longo que largo (2) é sinapomorfia do clado Borguyia albiornata+ e a presença de um trocânter muito 
mais longo do que largo, sendo aproximadamente duas vezes o comprimento que a largura, é sinapomorfia de Longiperna, com reversão em L. insperata.

58. Trocânter IV do macho - apófise apical dorsal:

$(\mathrm{L}=2 ; \mathrm{I} . \mathrm{C}=0.5 ; \mathrm{I} . \mathrm{R}=0.94)$

0. ausente

1. presente

Modificado do caráter 9 de Kury (1991). O estado plesiomórfico é a ausência de uma apófise apical dorsal externa no trocânter IV do macho (0). A presença dessa apófise
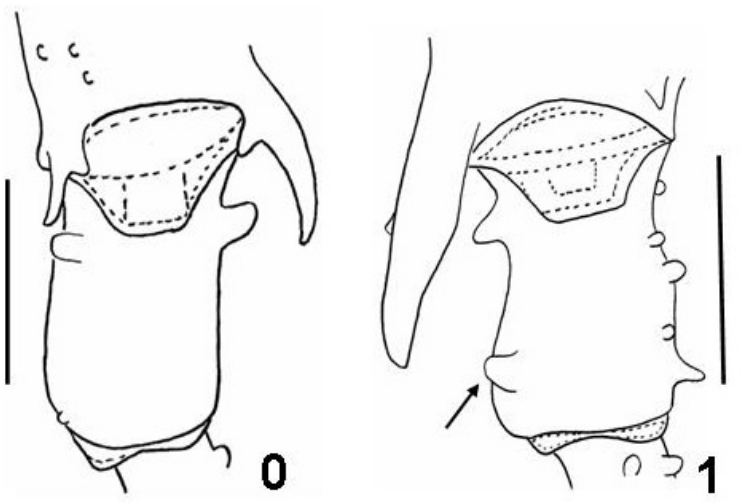

é sinapomorfia do clado Neoancistrotus + Promitobates, ocorrendo também em Bourguyia albiornata.

59. Trocânter IV do macho - apófise basal externa:

$(\mathrm{L}=1 ; \mathrm{I} . \mathrm{C}=1.0 ; \mathrm{I} . \mathrm{R}=1.0)$

0. ausente

1. presente

A presença de uma apófise basal externa no trocânter IV do macho (1) é plesiomórfica. A perda dessa apófise é sinapomorfia do clado [1] ): Ischnotherus +
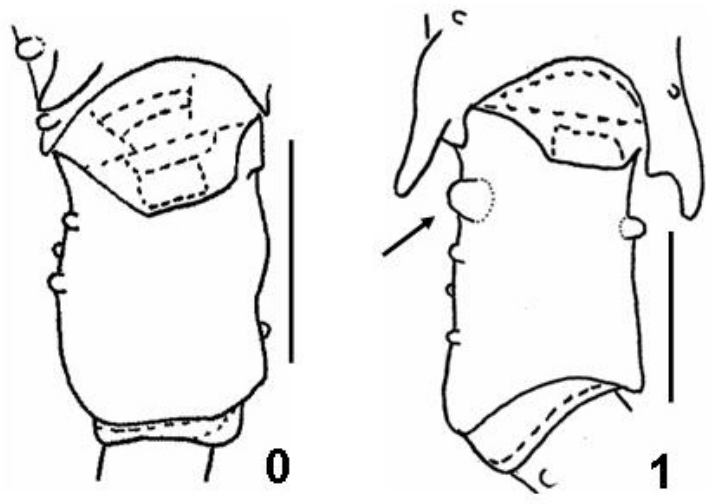

Encheiridium + Metamitobates + Ruschia + Mitobatula + Mitobates).

60. Trocânter IV do macho - apófise basal interna :

$(\mathrm{L}=2 ; \mathrm{I} . \mathrm{C}=0.5 ; \mathrm{I} . \mathrm{R}=0.8)$

0 . ausente

1. presente 
A presença de uma apófise basal interna no trocânter IV do macho (1) é sinapomorfia de Discocyrtoides + Longiperna, ocorrendo homoplasticamente em Discocyrtus testudineus.
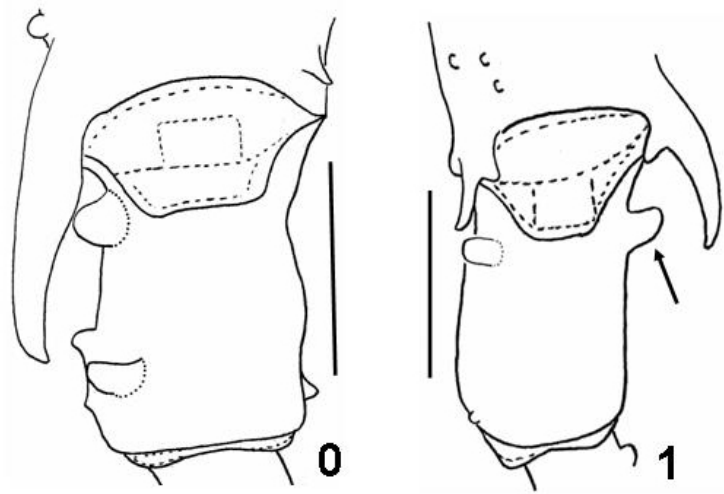

61. Trocânter IV do macho - apófise apical interna:

$(\mathrm{L}=3 ; \mathrm{I} . \mathrm{C}=0.33 ; \mathrm{I} . \mathrm{R}=0.87)$

0. ausente

1. presente

A presença de uma apófise apical interna no trocânter IV do macho (1) é plesiomórfico. A perda dessa apófise ocorre como sinapomorfia de Mitobatinae (e homoplasticamente em
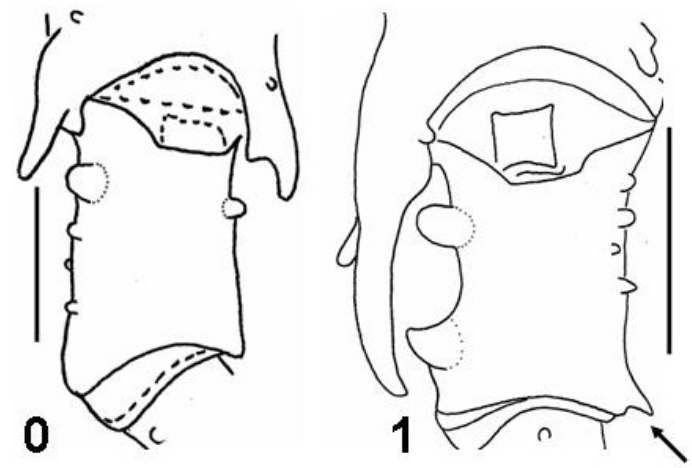

Caelopygus elegans), voltando a aparecer no clado Neoancistrotus + Promitobates.

\section{Fêmur IV machos - comprimento:}

$(L=4 ; I . C=0.50 ; I . R=0.80)$

0. curto

1. longo (até três vezes o comprimento do ED)

2. muito longo (maior que quatro vezes o tamanho do escudo dorsal)

Modificado do caráter 22 de Kury (1991). O fêmur IV curto (0) é plesiomórfico, tornando-se longo (1) em Bourguyia albiornata+ (tornando-se novamente curto homoplasticamente em Discocyrtus testudineus). Fêmur IV muito longo (2) é sinapomorfia de Mitobatinae, com reversão para o estado "1" em Neoancistrotus. 
63. Fêmur IV machos - tubérculos/apófises:

$(\mathrm{L}=1 ; \mathrm{I} . \mathrm{C}=1.0 ; \mathrm{I} . \mathrm{R}=1.0)$

0. ausente

1. presente

Modificado do caráter 22 de Kury (1991). A ausência de tubérculos ou apófises espiniformes no fêmur IV dos machos é sinapomorfia de Mitobatinae.

64. Fêmur IV machos - formato:

$(\mathrm{L}=23 ; \mathrm{I} . \mathrm{C}=0.50 ; \mathrm{I} . \mathrm{R}=0.50)$

0 . curvado

1. reto

Equivale ao caráter 32 de Yamaguti \& Pinto-da-Rocha (2009). Optando-se por otimização ACCTRAN, a mudança para fêmur IV reto (1) ocorre em Bourguyia albiornata +, com reversão no grupo-externo em Discocyrtus testudineus.Com otimização DELTRAN, a mudança para fêmur reto (1) ocorre independentemente em B. albiornata, C. elegans e no clado Despirus parvulus+.

\section{Tíbia IV machos - comprimento:}

$(\mathrm{L}=1 ; \mathrm{I} . \mathrm{C}=1.0 ; \mathrm{I} . \mathrm{R}=1.0)$

0. curta - menor do que duas vezes o comprimento do escudo dorsal

1. longa - maior que duas vezes o comprimento do escudo dorsal

A tíbia IV longa (1) é sinapomorfia de Mitobatinae.

\section{COLORAÇÃO}

66. Coloração - círculo claro em torno dos tubérculos das áreas I-IV:

$(\mathrm{L}=4$; I. $\mathrm{C}=0.25 ; \mathrm{I} . \mathrm{R}=0.57)$

0. ausente

1. presente 
A presença desse padrão de coloração, com círculos da mesma coloração dos tubérculos ao redor destes no escudo dorsal (1) ocorre homoplasticamente nos clados Mitobatula castanea+ e Promitobates sp.n2+. É perdida posteriormente em Promitobates ornatus 1 e readquirida em $P$. hatschbachi.

67. Coloração - tubérculos do dorso amarelo muito destacado:

$(\mathrm{L}=3$; I. $\mathrm{C}=0.33 ; \mathrm{I} . \mathrm{R}=0.75)$

0 . ausente

1. presente

A presença de tubérculos amarelo sulfúreos no escudo dorsal (1) é sinapomorfia homoplástica de Mitobatula + Mitobates e do clado Promitobates difficilis+, com reversão em Promitobates sp.n4+

\section{Coloração - Escudo dorsal com "manchas" brancas pareadas:}

0. ausente

1. presente

Modificado do caráter 31 de Kury (1991). A presença de manchas brancas pareadas no escudo dorsal (1), abaixo da cutícula e que se tornam muito mais evidente com o animal vivo ou seco, é sinapomorfia do gênero Ruschia

\section{Coloração - apófíse externa coxa IV:}

$(\mathrm{L}=4 ; \mathrm{I} . \mathrm{C}=0.25 ; \mathrm{I} . \mathrm{R}=0.25)$

0 . semelhante ao segmento

1. enegrecida

O estado plesiomórfico é a apófise externa da coxa IV da mesma cor do restante do artículo (0). Optando-se por otimização ACCTRAN, a coloração enegrecida (formado por pigmentação da epiderme) (1) ocorre no grupo-externo como autapomorfia homoplástica de Caelopygus elegans e em Mitobatinae surge em Discocurtoides nigricans e Promitobates sp.n1+, sendo posteriormente perdida 
em P.viridigranulatus e $P$. difficilis ${ }^{+}$. Optando-se por otimização DELTRAN, o estado "1" surge independentemente em C. elegans, no grupo-externo, e em $D$. nigricans, Promitobates sp.n1, Promitobates sp.n2, e Promitobates sp.n3.

70. Coloração - trocânter IV:

$(\mathrm{L}=2 ; \mathrm{I} . \mathrm{C}=0.50 ; \mathrm{I} . \mathrm{R}=0)$

0. semelhantes aos demais artículos

1. enegrecido

O trocânter IV enegrecido (formado por pigmentação da epiderme), diferenciando-se dos demais artículos da perna IV é autapomorfia homoplástica de Promitobates sp.n2, e Promitobates sp.n3.

71. Coloração - fềmures I-IV dos machos tigrado:

$(\mathrm{L}=2 ; \mathrm{I} . \mathrm{C}=0.50 ; \mathrm{I} . \mathrm{R}=0.50)$

0 . ausente

1. presente

Modificado do caráter 13 de Kury (1991). O padrão de coloração dos fêmures IV em retículo tigrado (formado por pigmentação da epiderme) (1) é sinapomorfia do gênero Ischnotherus, compartilhado homoplasticamente com Ruschia maculata.

72. Coloração - terço central dos tergitos livres claros:

$(\mathrm{L}=3 ; \mathrm{I} . \mathrm{C}=0.33 ; \mathrm{I} . \mathrm{R}=0.87)$

0. ausente

1. presente

Os tergitos apresentando a região central com coloração sempre mais clara que o restante do corpo (1) é sinapomorfia do gênero Ischnotherus.

73. Mancha seca - presença nos tergitos livres: 
$(\mathrm{L}=7 ; \mathrm{I} . \mathrm{C}=0.14 ; \mathrm{I} . \mathrm{R}=0.45)$

0. ausente

1. presente

Este caráter se mostrou bastante homoplástico e a ausência de mancha seca em alguns táxons deve ser vista com cautela, uma vez que a mancha seca nos tergitos livres não é muito espessa e sua visualização em material preservado há muito tempo pode ser bastante prejudicada. É o caso, por exemplo, de alguns terminais de Mitobates, Longiperna e Neoancistrotus, cujo volume de material era escasso e despigmentado. Ainda assim, o caráter apresentou sinal filogenético e optou-se por incluí-lo na análise.

O estado plesiomórfico é a ausência de mancha seca nos tergitos livres (0). A presença de mancha seca (1) ocorre, no grupo-externo, em Discocyrtus testudineus. Em Mitobatinae, ocorre homoplasticamente em Mitobatula castanea, Mitobates triangulus, Longiperna concolor, Promitobates bellus+ (compartilhado por Promitobates sp.n4). É perdida posteriormente no clado P. ornatus 1+.

74. Mancha seca - faixa longitudinal na coxa IV:

$(\mathrm{L}=2 ; \mathrm{I} . \mathrm{C}=0.50 ; \mathrm{I} . \mathrm{R}=0.88)$

0. ausente

1. presente

A presença de uma mancha seca em faixa longitudinal na coxa IV (1) é sinapomorfia homoplástica de Metamitobates squalidus + e do clado [2] (Discocyrtoides + Longiperna + Neoancistrotus + Promitobates).

\section{DIMORFISMO SEXUAL}

75. Dimorfismo sexual no comprimento dos artículos da perna IV:

$(\mathrm{L}=1 ; \mathrm{I} . \mathrm{C}=1.0 ; \mathrm{I} . \mathrm{R}=1.0)$

0. ausente

1. presente 
Dimorfismo sexual no comprimento dos artículos da perna IV (1) é sinapomorfia de Despirus parvulus+. 


\section{IV.1.2. Padrões gerais e discussão dos caracteres}

As estruturas morfológicas que contribuíram com o maior número de caracteres para a análise filogenética foram as armações e ornamentações (presença e distribuição dos tubérculos) do escudo dorsal, representando 21 dos 75 caracteres. Forma, tamanho e, principalmente a armação dos artículos do apêndice IV dos machos também contribuíram com um número representativo de caracteres e foram responsáveis por importantes sinapomorfias dos clados de Mitobatinae (representando 19 caracteres).

Os caracteres de tamanho/forma e ornamentação escudo dorsal estiveram principalmente relacionados à evolução dentro dos gêneros. Em Promitobates, somaram 27 caracteres, sendo responsáveis por estabelecer o relacionamento de grande parte das espécies. Esses caracteres também representaram importantes sinapomorfias de diversos clados (Mitobatula + Mitobates, p.e., com três caracteres) e também na formação dos dois grandes grupos de Mitobatinae [1] e [2].

Os dois grandes grupos de Mitobatinae [1] e [2] são sustentados principalmente por caracteres dos apêndices da perna IV (cada um com três sinapomorfias relacionados à armação ou tamanho dos artículos da perna IV dos machos). Esses caracteres também foram fundamentais para estabelecer o relacionamento entre alguns gêneros, como diferenciar o clado Ischnotherus+ dos demais clados e separar Discocyrtoides nigricans do gênero Longiperna. Também foi importante para estabelecer as relações dentro de alguns gêneros, como, p.e., Longiperna e entre grande parte das espécies de Promitobates.

Caracteres de genitália masculina, representados por 19 caracteres,

foram bastante homogêneos dentro dos gêneros de Mitobatinae. Tais caracteres foram mais importantes para a resolução das relações entre o grupo-externo e Mitobatinae, entre os gêneros ou mesmo para a definição destes. Promitobates, por exemplo, é sustentado por oito sinapomorfias de genitália masculina e o clado Encheiridium ruchii+ apenas por sinapomorfias do pênis (quatro sinapomorfias homoplásticas). Exceções podem ser observadas, p.e., entre as espécies de Longiperna, onde as espécies $L$. concolor $+L$. cancellata se distinguem das demais por três caracteres do pênis. 


\section{IV.1.3. Relação entre os gêneros de Mitobatinae}

A hipótese filogenética apresentada nesse estudo, representada por duas árvores mais parcimoniosas na análise cladística ( $L=257$; C.I=0.38; R.I=0.72), confirma Mitobatinae como táxon monofilético (Figura 2). A única divergência entre as duas árvores encontradas está no posicionamento entre duas espécies de Longiperna ( $L$. coxalis e $L$. insperata) em relação às demais espécies do gênero.

$\mathrm{Na}$ presente hipótese, Mitobatinae é grupo-irmão de Despirus parvulus e composto por dois grandes clados; [1] um grupo que possui corpo grosseiramente retangular e machos e fêmeas com a coxa e o trocânter IV inermes, ou com apófises muito reduzidas e um segundo grupo [2] que apresenta corpo grosseiramente piriforme e dimorfismo sexual na coxa e trocânter IV, com os machos apresentando principalmente forte armação externa na coxa e apófises maiores no trocânter.

O monofiletismo de Mitobatinae, suportado por um indice de Bremer 3, é sustentado por cinco sinapomorfias não-ambíguas, sendo quatro exclusivas: comprimento do fêmur IV dos machos muito maior que o comprimento do escudo dorsal; fêmur IV dos machos sem fileiras ventrais de tubérculos ou apófises; tíbia IV dos machos maior do que duas vezes o comprimento do escudo dorsal e uma sinapomorfia de genitália, com relação ao tamanho tronco do pênis, que em vista lateral ultrapassa a base da placa ventral. Alguns caracteres ambíguos podem ser sinapomorfias (não-exclusivas) de Mitobatinae em otimização ACCTRAN: perda da apófise interna apical do trocânter IV (com reversão em Neoancistrotus+) placa ventral do pênis sem depressão horizontal mediana (embora homoplástico em Encheiridium ruschii+ e Promitobates).

A distinção de Mitobatinae em dois grandes grupos é uma hipótese bastante distinta da proposta por Kury (1991d). No trabalho de Kury (Figura 1), Discocyrtoides estava posicionado na base da subfamília, grupo-irmão dos demais gêneros. Na atual proposta, Despirus parvulus é irmão de Mitobatinae, que por sua vez é separado nos dois clados; Discocyrtoides é grupo-irmão de Longiperna e fazem parte do segundo grande clado de Mitobatinae [2] juntamente com Neoancistrotus. De fato, dentre todos os clados internos de Mitobatinae propostos por Kury, em 1991, apenas o nó 7 (Figura1) (Ruschia + Mitobatula + Mitobates ) foi mantido como monofilético no presente estudo.

O primeiro grande clado de Mitobatinae [1], possui suporte de Bremer 4 e é sustentado por cinco sinapomorfias, sendo quatro não ambíguas e três 
exclusivas: relação entre a largura do prossoma e abdômen semelhantes e, ausência de apófise externa na coxa IV e perda da apófise basal externa do trocânter IV. Este clado é formado por sete gêneros. O gênero Ischnotherus (com duas espécies válidas), monofilético, é sustentado por quatro sinapomorfias não ambíguas, sendo sinapomorfia exclusiva a coloração típica do terço central dos tergitos livres. Ichnotherus é grupo-irmão dos demais seis gêneros que compõem um outro grupo monofilético, sustentado por quatro sinapomorfias. Neste segundo grupo, apenas o monofiletismo do gênero Encheiridium (com duas espécies válidas) não foi corroborado, E. montanum sendo grupo-irmão de Metamitobates + Ruschia + Mitobatula + Mitobates. Como dito anteriormente, o clado Ruschia + Mitobatula + Mitobates também foi proposto por Kury (1991d). Entretanto, no presente estudo Mitobatula (gênero monotípico) é grupo-irmão de Mitobates, sustentado por seis sinapomorfias, cinco não ambíguas e índice de Bremer 4. Em Kury (1991d) Ruschia formava um grupo com Mitobates, sustentado por quatro sinapomorfias, dentre as quais, duas não foram empregadas no presente estudo (por se tratar de caracteres de fêmeas), uma será discutida adiante na seção de caracteres quantitativos e a última (formato do leque da glande) constituiu-se autapomorfias homoplásticas.

O segundo grande clado [2] é sustentado por cinco sinapomorfias, sendo três não ambíguas: coxa IV dos machos com apófise externa bifurcada; região interna da coxa IV dos machos amplamente visivel em superficie dorsal e coxa IV maior que o comprimento do escudo dorsal. Esse clado, por sua vez, é separado em dois outros clados, um formado pelos gêneros Discocyrtoides + Longiperna e outro formado por Neoancistrotus + Promitobates. O primeiro clado (Discocyrtoides + Longiperna) é sustentado por cinco sinapomorfias, duas exclusivas: coxa IV dos machos com apófise interna bifurcada e de tamanho semelhante à externa. O segundo (Neoancistrotus + Promitobates) possui suporte de Bremer 2 e é sustentado por cinco sinapomorfias homoplásticas, sendo quatro não ambíguas. A característica morfológica mais marcante deste grupo é a presença de uma apófise dorsal apical no trocânter IV dos machos. Neoancistrotus emergiu como agrupamento monofilético e sustentado por cinco sinapomorfias, sendo exclusivo o formato do ápice do processo ventral, que é o mais estreito entre os Mitobatinae.

O gênero Promitobates confirmou-se como monofilético, com um elevado índice de Bremer e sustentado por 12 sinapomorfias, sendo nove não ambíguas e duas exclusivas: presença de uma estrutura arredondada nas laterais do ápice 
da placa ventral e orientação das franjas do leque do processo ventral para baixo, dando à estrutura um formato cocleariforme. Outras sinapomorfias do gênero são: processo ventral longo, tronco do pênis ultrapassando muito o limite da placa ventral em vista lateral e borda posterior do escudo dorsal armada com tubérculos ou apófises espiniformes.

Dentre as espécies com polimorfismos que foram decompostas em subunidades monomórficas na análise, apenas as quatro unidades de $P$. ornatus não formaram um grupo monofilético. Apesar de o gênero possuir um alto suporte de Bremer, o mesmo não acontece com as relações internas que na sua grande maioria, possuem o suporte mínimo. P. bellus está posicionado na base do gênero e as demais espécies apresentam cinco sinapomorfias, sendo três exclusivas que as separam dela. $P$. sp.n1, espécie que apresenta um aspecto morfológico diferenciado, o que fica evidente pelo grande número de autapomorfias (sete), é grupo-irmão das demais espécies do gênero. O gênero é então dividido em dois clados, um formado por P. sp.n3 + P.viridigranulatus (unidades monomórficas P.viridigranulatus1 + P.viridigranulatus2), que compartilham cinco sinapomorfias, sendo exclusiva a área IV do escudo dorsal totalmente preenchida por tubérculos. O outro clado é sustentado por três sinapomorfias e formado por $P$. sp.n2 posicionado na base, seguido de $P$. difficilis. Têm-se então uma nova divisão com um grupo monofilético incluindo três das quatro unidades monomórficas de P. ornatus (P.ornatus1 + P.ornatus3 + P.ornatus4), sustentados por apenas uma sinapomorfia: áreas III e IV do escudo dorsal totalmente separadas; e um último grupo - P.ornatus2 + P. sp.n4+ $P$. hatschbachi (unidades monomórficas P.hatschbachi1 + P.hatschbachi2) - também sustentado por duas sinapomorfias: presença de uma fileira de tubérculos na margem da área IV e espinhos da área III cilíndricos.

\section{IV.1.4. Análise cladística - hipóteses alternativas}

Apesar das duas árvores encontradas na análise sem pesagem dos caracteres terem sido muito semelhantes, a hipótese de relacionamento gerada difere muito daquela proposta por Kury (1991d). O autor utilizou, além dos caracteres qualitativos, dos quais a grande maioria foi também empregada no presente estudo, um grande número de caracteres quantitativos. Do total de 57 caracteres empregados em sua analise, 31 foram qualitativos e 27 foram 
quantitativos (representando mais de $46 \%$ do total). O emprego de caracteres quantitativos em analise filogenética é bastante polêmico na literatura cladística. Pimentel \& Riggins (1987) foram contra sua utilização, baseados no argumento de que eles se sobrepõem entre as espécies. Segundo Thiele (1993), a distinção entre qualitativo e quantitativo é muito mais aparente do que real, já que muitos caracteres - senão todos - denominados como qualitativos são de natureza quantitativa (Stevens, 1991; Thiele, 1993). Desta maneira, distinção entre caracteres qualitativos e quantitativos faz mais sentido se utilizado como sinônimo de dados sem sobreposição e com sobreposição, respectivamente (Mayr, 1969; Thiele, 1993). Chappil (1989), apesar de propor uma metodologia para tratar caracteres quantitativos, argumenta que a sua utilização deve ser restrita aos casos onde os caracteres qualitativos forem insuficientes para resolver as relações filogenéticas. No presente estudo, foi possivel propôr uma hipótese de relacionamento totalmente resolvida entre os gêneros de Mitobatinae apenas com o emprego de caracteres qualitativos, porém como as relações entre os gêneros deferiram quase que em sua totalidade com àquela proposta por Kury, foi realizada também uma análise com alguns dos caracteres quantitativos utilizados por Kury (1991d). Optou-se por não incluir todos os caracteres previamente utilizados, uma vez que grande parte (cerca de 40\%) fazia referência às fêmeas. Outros eram redundantes e o seu emprego levaria à sobrepesagem de algumas características (para detalhes, ver item VI.1 de Resultados e Discussão sobre a escolha de caracteres para análise cladística). A topologia resultante foi exatamente a mesma proposta sem o emprego dos caracteres quantitativos, demonstrando que o emprego desses dados não altera a hipótese de o relacionamento entre os gêneros de Mitobatinae.

Para verificar a consequência da ordenação de alguns caracteres sobre o resultado, e também explorar os dados frente a diferentes metodologias (visto à grande diferença encontrada com as hipóteses obtidas por Kury), foram realizadas análises com todos os caracteres não-aditivos e análises com pesagem implícita.

A análise com os caracteres multiestado não ordenados teve como resultado também duas árvores mais parcimoniosoas $(\mathrm{L}=255 ;$ I.C $=0.38$; I.R=0.72). As hipóteses de relacionamento do grupo interno mativeram-se exatamente as mesmas que as geradas com a ordenação a priori dos caracteres multiestado (Figura 3). Uma única modificação ocorreu no posicionamento de Bourguyia albiornata, no grupo-externo, que com ordenação ocupa uma posição 
mais derivada em relação à Pachylus chilensis e sem a ordenação ocupa uma posição mais basal na topologia (Figura 3).

O método de pesagem implícita foi proposto por Goloboff (1993) como alternativa à pesagem sucessiva, é facilmente implementável e tem sido amplamente utilizado em análises cladísticas. Segundo Goloboff, a pesagem de caracteres durante a busca possibilita o ajuste dos caracteres conforme a adição de táxons, e o resultado final deve mostrar o ajuste máximo, denominado total fit. A pesagem sucessiva recebeu críticas de Goloboff $(1993$; 1997) por manter o peso dos caracteres durante a busca e também por utilizar parâmetros de uma análise prévia para determinar o peso dos caracteres na busca com pesagem.

Em relação às diferentes concavidades do peso de acordo com a quantidade de homoplasias que podem ser utilizadas na pesagem implícita, é difícil tomar qualquer decisão que seja totalmente livre de arbitrariedade. Goloboff (1993), quando propôs a metodologia, admitiu que a escolha da concavidade devesse ser melhor investigada. Exceto pelos resultados obtidos com indice de concavidade $\mathrm{k}=1$, os resultados obtidos de pesagem implícita (tabela 3) mantém Mitobatinae monofilético, grupo-irmão de Despirus parvulus e composto pelos dois grandes clados: [1] Ischnotherus + Encheiridium + Metamitobates + Ruschia + Mitobatula + Mitobates e [2] Discocyrtoides + Longiperna + Neoancistrotus + Promitobates.

A árvore obtida com baixo índice de concavidade $(\mathrm{k}=1)$ apresenta uma topologia muito diferente das demais (Figura 4). Isto se deve a um forte enfraquecimento dado aos caracteres que apresentam homoplasia, e provavelmente a maneira radical como este enfraquecimento é aplicado aos caracteres. Além disso, o comprimento da árvore gerada é muito maior do que o gerado pelos demais índices e mesmo quando comparado com topologia gerada sem pesagem dos caracteres (tabela 3). Índices de concavidade $\mathrm{k}=2$ a $\mathrm{k}=5$ geraram topologias praticamente idênticas entre si, com variação apenas entre três terminais de Promitobates (P. viridigranulatus 1 e 2 e $P$. sp.n3) e semelhantes com a obtida sem pesagem, incluindo o número de passos (Figura 5). No grupointerno, há uma mudança no relacionamento entre os gêneros do grupo [1], com Encheiridium emergindo como gênero monofilético, assumindo uma posição basal, grupo-irmão dos demais gêneros. No grupo [2], as hipóteses de relacionamento entre as espécies de Longiperna foram resolvidas e pequenas mudanças de posicionamento entre as espécies de Promitobates ocorrem. Por fim, implementando-se a pesagem com indice de concavidade $\mathrm{k}=6$ (Figura 6), a 
topologia resultante é extremamente semelhante à obtida sem pesagem (Figura 2), mas com resolução entre as relações do gênero Longiperna e, em Promitobates, mudança no posicionamento de $P$. sp.n1 e do clado $P$. sp.n3+. Na árvore sem pesagem (Figura 2), P. bellus ocupa a posição mais basal do gênero, ao passo que quando empregado pesagem com concavidade $\mathrm{k}=6$, P.sp.n1 assume a posição a basal. Ambas as espécies possuem morfologia bastante diferenciada das demais espécies do gênero.

Portanto, descartando-se a topologia gerada pelo índice de concavidade $\mathrm{k}=$ 1 , todas as hipótes foram bastante congruentes com a gerada sem emprego de pesagem. A definição de Mitobatinae monofilético, irmão de Despirus parvulus e formado por dois principais clados, e não com relacionamento assimétrico entre os gêneros conforme sugerido por Kury, é sustentado tanto pelo tratamento não aditivo dos caracteres quanto pelo emprego de cinco dos seis índices de concavidade e, exceto pela mudança de posicionamento entre Ischnotherus e Encheiridium na posição basal do grupo [1], as principais relações dentro dos clados se mantiveram.

Tabela 2. Resultados da análise cladística de Mitobatinae implemetada com o programa TNT, com pesagem implícita em diferentes valores de $\mathrm{K}$.

\begin{tabular}{|cccc|}
\hline $\mathbf{K}$ & $\mathbf{N}^{\circ}$ Árvores & Total Fit & Comprimento \\
\hline 1 & 1 & 34.25 & 263 \\
2 & 1 & 42.22 & 259 \\
3 & 1 & 47.13 & 257 \\
4 & 1 & 50.55 & 257 \\
5 & 1 & 53.07 & 257 \\
6 & 1 & 55.02 & 255 \\
\hline
\end{tabular}




\section{IV.1.5. Implicações taxonômicas}

Inicialmente, deve-se ressaltar que este trabalho não teve o objetivo de realizar uma atualização taxonômica de Mitobatinae, uma vez que nem todas as espécies do grupo foram contempladas no estudo. Mitobates é composto por quatro espécies válidas, sendo que $M$. eleganthulus não foi incluída na análise e Neoancistrotus, que é composto por 12 espécies, teve apenas três incluídas. Longiperna, segundo Kury (2003), é composta por nove espécies. Entretanto, a presente autora está realizando a revisão deste gênero e diversas sinonímias já foram detectadas (Bragagnolo, em prep.). Assim, as quatro espécies incluídas nesta análise abrangem o total de espécies morfologicamente válidas do gênero. Os demais gêneros possuem apenas duas espécies ou são monotípicos, de maneira que foram totalmente contemplados.

A monofilia do gênero Encheiridium não foi resgatada em todas as análises. Entretanto, utilizando-se pesagem implícita, o grupo emergiu como monofilético com cinco dos seis índices de concavidade empregados (Figuras 4 a 6), o que indica que o número de homoplasias pode ter mascarado ou prejudicado a visualização entre as relações das espécies desse grupo. Desta maneira, é recomendável uma análise mais minuciosa dessas duas espécies antes de uma decisão taxonômica.

Mitobatinae, definida pelas sinapomorfias já acima discutidas e separada em dois grupos [1] e [2], não inclui a espécie Despirus parvulus, atualmente dentro de Mitobatinae (Kury, 2003). Por outro lado, em todas as análises (nos oito diferentes tratamentos dos dados), D. parvulus emergiu como espécie-irmã de Mitobatinae, e a manutenção dessa espécie dentro da subfamília poderia parecer a decisão taxonômica mais conservadora a ser tomada. Entretanto, considerar D. parvulus como Mitobatinae acarretaria grandes mudanças na diagnose da subfamília. Os integrantes de Mitobatinae são facilmente reconhecidos por apresentar um marcado dimorfismo sexual no comprimento dos artículos das pernas IV dos machos, sendo este mais que quatro vezes o comprimento do escudo dorsal. Esta característica é apenas menos evidente no gênero Neoancistrotus, onde a relação é de apenas três vezes o comprimento do escudo dorsal, semelhante à de $D$. parvulus. Além disso, integrantes desse grupo possuem o fêmur IV reto e sem a presença de fileiras de tubérculos e/ou apófises espiniformes, uma característica bastante comum nos Gonyleptidae. As 
características acima descritas surgiram como sinapomorfia do clado formado pelos dois principais grupos de Mitobatinae [1] e [2], mas não é compartilhado por $D$. parvulus. As únicas sinapomorfias exclusivas que sustentam $D$. parvulus juntamente com os demais integrantes de Mitobatinae são as proporções entre a largura do prossoma e abdômen (com mudança de estado no grupo [2]) e a ocorrência de dimorfismo sexual no comprimento dos artículos das pernas IV, cabendo ressaltar que nunca alcançando o comprimento observado nos demais gêneros de Mitobatinae. A presença desse tipo de dimorfismo é também observada em outros grupos de Gonyleptidae, como nos gêneros Pseudogyndesoides e Hypophyllonomus, da subfamília Pachylinae. Morfologicamente, esses grupos possuem semelhanças com $D$. parvulus, no que concerne à armação do escudo dorsal, tamanho e armação do fêmur IV e tamanho e forma geral do corpo. Kury (1991d) já propõe D. parvulus como grupoirmão de Mitobatinae, dentro de um grupo denominado por ele de "Discocyrtinae", juntamente com outras espécies de Pachylinae. O pênis de $D$. parvulus possui características como formato placa ventral, número e forma das setas e presença de depressão mediana bastante típicas dos Pachylinae. Por outro lado, o processo ventral tripartido é uma característica bastante incomum e constitui, possivelmente, autapomorfia dessa espécie. Infelizmente, integrantes de Pseudogyndesoides e de Hypophyllonomus não foram incluídos no grupoexterno e as relações com $D$. parvulus não puderam ser testadas.

\section{IV.1.6. Polimorfismos em Promitobates}

A clareza na seleção dos caracteres a serem incluídos na análise cladística é parte fundamental para garantir a qualidade das hipóteses geradas, uma vez que há diferentes tipos de caracteres, com propriedades particulares (Wiens, 2000). Em análises onde os terminais são táxons superiores, caracteres ideais são aqueles que variam entre as unidades terminais, mas que não variam dentro deles (Thiele, 1993). Entretanto, é comum encontrar que muitos caracteres variam dentro dessas unidades (Mayr, 1969; Nixon \& Davis, 1991; Wiens \& Servedio, 1997; Kornet \& Turner, 1999). Polimorfismos são definidos como a presença de dois ou mais estados de um caráter no mesmo táxon terminal em estudo. 
A maioria dos autores consideram fundamentalmente distinta a variação de caracteres dentro de uma mesma espécie (polimorfismo) da variação dentro de um agrupamento de espécies, denominada de polimorfismo taxonômico (Nixon \& Davis, 1991; Simmons \& Geisler, 2002; Prendini, 2001). É considerado também como polimorfismo apenas a variação em caracteres discretos e/ou qualitativos, ou ao menos, descritos qualitativamente (Thiele, 1993). Tal separação é bastante controversa, uma vez que a distinção entre qualitativo e quantitativo é muito mais aparente do que real, já que muitos caracteres - senão todos - denominados como qualitativos são de natureza quantitativa (Stevens, 1991; Thiele, 1993). Desta maneira, distinção entre caracteres qualitativos e quantitativos faz mais sentido se utilizado como sinônimo de dados sem sobreposição e com sobreposição, respectivamente (Mayr, 1969; Thiele, 1993).

Os caracteres polimórficos são de utilidade filogenética, mas sua utilização depende da forma como estes caracteres são tratados e codificados na matriz de dados. Apesar de haver uma variedade de métodos para tratar variação em análises cladísticas, grande parte das publicações simplesmente exclui os caracteres polimórficos, sem sequer mencioná-los (Campbell \& Frost, 1993). No geral, morfologistas raramente mencionam como a variação foi tratada em seus estudos, apesar de diferentes metodologias implicarem muitas vezes em diferentes topologias (Kornet $\&$ Turner, 1999; Wiens, 2000).

Existem basicamente duas categorias de métodos de parcimônia para codificar caracteres polimórficos: (1) aqueles que consideram que o polimorfismo é filogeneticamente informativo e (2) aqueles que consideram apenas como informativo a fixação do caráter (Kornet \& Turner, 1999).

Considerando que características não fixadas sejam filogeneticamente informativas, os polimorfismos podem ser codificados como:

1. Cada estado do caráter polimórfico codificado como presente ou ausente em uma coluna separada, ou seja, o caráter polimórfico é separado em caracteres binários;

2. Possuindo o estado apomórfico do caráter (método denominado "anyinstance" por Campbell \& Frost, 1993);

3. Um estado de caráter distinto, em uma série de transformação multiestado (incluindo os métodos de freqüência de Mabee \& Humphries, 1993; e "scaled" e "unscaled" de Campbell \& Frost, 1993);

4. Possuindo o estado que é mais comum entre os indivíduos amostrados (método de maioria). 
Por outro lado, considerando apenas a fixação das características como filogeneticamente informativas, os polimorfismos pode ser codificados como:

5. Possuindo estado plesiomórfico do caráter;

6. Estado desconhecido ("missing data");

7. Os estados polimórficos observados são inseridos na matriz.

Diversos autores assumem ainda a possibilidade de dividir o táxon polimórfico em sub-unidades menores, que não variem morfologicamente (Nixon \& Davis, 1991; Wiens, 1995, 1999; Kornet \& Turner, 1999). Entretanto, na literatura em geral, tal metodologia é restrita a táxons supra-específicos, baseados na pressuposição de que espécies representariam as menores unidades monofiléticas e subdividi-las em unidades menores, monomórficas, iria abaixo deste nível mínimo (Kornet \& Turner, 1999). Por outro lado, em análises filogenéticas com dados moleculares, indivíduos são utilizados como unidades terminais (Vrana \& Wheeler 1992). Essa metodologia é bastante discutida, uma vez que pode tratar variação intra-específica da mesma forma que variação entre espécies (Smouse et al., 1991; Wiens, 1999). Por outro lado, a amostragem de apenas um indivíduo por espécie também é controversa pelos mesmos motivos, mas amplamente empregado em análises filogenéticas (Smouse et al. 1991; Wiens \& Servedio, 1997; Wiens, 1999). Segundo Wiens (2000), separar uma espécie em sub-unidades monomórficas poderia não considerar os polimorfismos compartilhados entre espécies como sinapomorfias, o que faria com que alguns indivíduos de diferentes espécies fossem agrupados com base em seus polimorfismos compartilhados, transformando as espécies em não monofiléticas e trataria polimorfismos como homoplasias. Por outro lado, a presença de polimorfismo em uma determinada espécie pode, de fato, indicar a presença de mais de uma espécie (Wiens, 2000) e neste caso, a separação do terminal em subunidades monomórficas é a única forma de abordar a situação.

Em relação aos demais métodos de parcimônia para codificação de polimorfismo, diversos autores têm debatido sua eficiência e aplicabilidade (Grant \& Kluge, 2003). Nixon \& Davis (1991) criticaram a codificação de polimorfismo como estados desconhecidos e sugeriram a divisão do táxon (supraespecífico) em subunidades monomórficas. Campbell \& Frost (1993) criaram e compararam diversos métodos para codificar polimorfismo intra-específico, sugerindo codificá-los como um estado distinto, denominado de "unscaled". Neste método, cada combinação de estado - monomórfico - é codificado como estado próprio, e todos os estados são ordenados. Mabee \& Humphries (1993) 
também optaram por codificar polimorfismo como um estado de caráter distinto. Entretanto, diferentemente de Campbell \& Frost (1993), todos os estados são ordenados dentro da suposição de que características derivadas passam por um estágio polimórfico entre a ausência e a presença fixa (método denominado "scaled").

Wiens (1995, 1999 e 2000) e Smith \& Gutberlet (2001) em suas avaliações sobre a acurácia (relativo ao número de árvores mais parcimoniosas, número de caracteres informativos, sinal filogenético e sensibilidade ao tamanho da amostra) dos métodos para codificar polimorfismo, concluíram que os mais amplamente utilizados (codificação por maioria, como desconhecidos ou como polimórficos propriamente) não apresentam bons resultados. Esses autores e outros (Wiens \& Servedio, 1997; Chu, 1998) defendem os métodos de freqüência para codificar polimorfismo, no qual é utilizada diretamente a freqüência de ocorrência das características polimórficas observada nos terminais e pesos baixos são atribuídos às pequenas diferenças nas freqüências de ocorrência dos estados polimórficos entre as espécies e pesos mais elevados às grandes. Segundo Wiens $(1995,1999)$ tal metodologia estaria menos sujeita a erros de amostragem e usaria a variação de forma mais informativa que os demais métodos. Entretanto, Wiens (1995) ressalta a grande dependência dos seus resultados à forte ordenação imposta aos caracteres pelo método. Qualquer mudança pequena na freqüência do estado polimórfico irá ser vista como informativa, e uma grande mudança irá ser pesada muito mais fortemente do que uma pequena. De qualquer maneira, o uso de freqüências como sinal filogenético é muito questionado, devido à sua variabilidade no espaço e tempo (Mabee \& Humphries, 1993; Kornet \& Turner, 1999). Além disso, Wiens \& Servedio (1997) também observaram uma forte relação entre o emprego de codificação por freqüências e o aumento de homoplasias.

Kornet \& Turner (1999) avaliaram novamente os métodos empregados por Wiens, e compararam a capacidade dos diferentes métodos em atingir uma filogenia conhecida. Segundo os autores, todos os métodos que assumiram que a origem de uma novidade evolutiva era filogeneticamente informativa - o que inclui codificar polimorfismos como estados apomórficos, como um estado distinto em uma série de transformação multiestado ou aplicar o método de maioria, quando esta equivale ao estado apomórfico - geraram cladogramas incompativeis com a filogenia conhecida. Por outro lado, os métodos que consideraram somente as novidades fixas como filogeneticamente informativas - 
o que inclui codificar o táxon polimórfico como possuindo o estado plesiomórfico, codificar como estado de desconhecido ou como polimórfico propriamente geraram cladogramas mais compativeis com a real filogenia. Baseados nesses resultados, Kornet $\&$ Turner (1999) sugerem a inserção do estado polimórfico na matriz e analisá-lo de forma ambígua.

De uma maneira geral, apesar do relativo volume de artigos relacionados à codificação de polimorfismos em análise cladística publicados nas duas últimas décadas, atualmente, ainda há muita discussão sobre a melhor maneira de se tratar polimorfismo. Esse quadro é devido à incongruência entre os resultados obtidos pelos estudos, decorrentes de diferenças metodológicas e também de interpretação dos resultados, relacionados diretamente aos próprios princípios teóricos envolvidos em cada método.

A alta incidência de polimorfismos dentro de algumas espécies de Promitobates levou à grande dificuldade na codificação desses caracteres. Dentre todas as maneiras de codificação de polimorfismos acima citadas, a único que pode auxiliar no questionamento taxonômico é a decomposição das espécies polimórficas em subunidades menores, e assim o monofiletismo do grupo ser testado frente ao método cladístico. Os resultados da análise cladística utilizando esta metodologia indicaram $P$. hatschbachi (representada por P. hatschbachi1 + P.hatschbachi2) como monofilética sustentada por duas sinapomorfias e um suporte relativamente alto; $P$. viridigranulatus (representada por $P$. viridgranulatus1 + P.viridigranulatus2) também foi monofilética, sustentado por cinco sinapomorfias. As autapomorfias dos dois grupos foram justamente os polimorfismos observados, portanto, não há nenhum argumento a favor da separação delas em espécies nominais distintas. Entretanto, o mesmo não ocorreu com Promitobates ornatus. Das quatro unidades monomórficas, três emergiram como um grupo monofilético (P.ornatus1+3+4), grupo-irmão da outra unidade do grupo P. ornatus2 (a outra subunidade) + P. sp.n4 + P. hatschbachi. A partir desse quadro, é possivel propor algumas alterações taxonômicas. Inicialmente o primeiro grupo (P.ornatus1+3+4) parece ser um agrupamento distinto, mas sustentado por apenas uma sinapomorfia: separação entre as áreas III e IV do escudo dorsal, caráter de dificil codificação e que se mostrou extremamente homoplástico na análise, portanto com baixo sinal filogenético (CI $=0.16)$. A outra unidade $(P$. ornatus 2$)$ forma um outro clado também sustentado por duas sinapomorfias. 
Uma outra possibilidade é a separação do complexo $P$. ornatus em três espécies distintas. As unidades P.ornatus3 + P.ornatus4 possuem como sinapomorfia a armação do tergito livre III, caráter morfológico de fácil visualização e que apresentou sinal filogenético maior que o que mantém as três unidades $(\mathrm{CI}=0.33)$. As outras duas subunidades também seriam elevadas à espécies, resultando em três unidades monofiléticas e relativamente fáceis de serem reconhecidas morfologicamente. Desta maneira, Neoancistrotus nigripes, considerado sinônimo de P. ornatus por Kury (2003) é revalidado para abrigar as unidades P. ornatus3 + P. ornatus4; Batomites intermedius, sinonimizado por Soares (1943), também é revalidado para abrigar a unidade $P$. ornatus2 e a espécie nominal $P$. ornatus permanece para abrigar os representantes da unidade P. ornatus1.

A distribuição geográfica dessas três espécies são parcialmente sobrepostas (Figura 7C), entretanto, é possivel observar um padrão de distribuição entre as três: (1) P. nigripes ocorre desde a Mata Atlântica do sul do Paraná até São Paulo e é a única que atinge o interior de São Paulo/Paraná; (2) P. ornatus também ocorre na mata Atlântica de São Paulo, mas estende-se ao norte, alcançando o extremo norte do Rio de Janeiro e (3) P. intermedius, possui distribuição mais restrita, ocorrendo apenas próximo ao litoral de São Paulo, entre Paranapiacaba e Peruíbe.

Por fim, é preciso ressaltar que a separação do complexo $P$. ornatus em três espécies nominais distintas é a uma tentativa de definir espécies nominais de maneira mais objetiva utilizando apenas atributos morfológicos dentro de um contexto cladístico. A abordagem de polimorfismos em clados onde as espécies são em geral bastante homogêneas e distribuídas de forma bastante restrita (Figura 7A-C), contrastando com uma única espécie nominal, amplamente distribuída e polimórfica (Figura 7C), baseada apenas em uma análise morfológica, ainda que extensa e detalhada, pode não ser totalmente eficaz na delimitação de espécies tão complexas. Análises moleculares futuras poderão fornecer suporte às evidências morfológicas aqui encontradas e auxiliarão na melhor compreensão entre os limites de variação morfológica deste grupo. 


\section{IV.2 Taxonomia e Sistemática}

\section{IV.2.1. Chave para os machos de Promitobates}

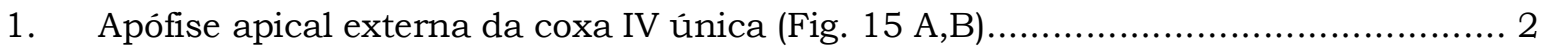

Apófise apical externa da coxa IV bifurcada (Figs 8, 9) .......................................

2. Oculário armado com um par de tubérculos baixos (Fig. 12B) ................... P. sp.n1 Oculário armado com um par de altas apófises espiniformes (Fig.12A B,E).... P. sp.n2

3. Borda posterior do escudo dorsal armada com par de tubérculos ou apófises espiniformes medianos (Figs. 8; 9A,B) ..........................................................

Borda posterior do escudo dorsal inerme, somente com fileira de tubérculos de tamanho semelhante (Fig. 9 C,D) .......................................... P. viridigranulatus

4. Extremidades apicais da coxa e trocânter IV e basal do fêmur IV muito enegrecidos, contrastando fortemente com o restante do corpo; área IV do escudo dorsal totalmente coberta por tubérculos (sem região lisa) (Fig. 10C)..................... P. sp.n3 Extremidades apicais da coxa e trocânter IV e basal do fêmur IV semelhante ao restante do segmento, ou levemente enegrecido, mas nunca em grande contraste com o resto do corpo; área IV com tubérculos nunca recobrindo a área toda (pelo menos as laterais com região lisa) (Figs. 8, 9, 10A,B,D) .................................... 5

5. Área I do escudo dorsal com poucos tubérculos (menos que 10 nas duas), esparsamente distribuídos; Oculário amarelo-sulfúreo, contrastando fortemente com o restante do corpo (Fig. 8A). P. bellus

Área I do escudo dorsal densamente tuberculada ou com estes acompanhando o sulco posterior da área (grosseiramente em fileiras); Oculário não contrastando com o restante do corpo (da mesma cor ou levemente amarelado) (Figs. 8 B-D; 9; 10)

6

6. Áreas III e IV do escudo dorsal densamente tuberculada, exceto em torno das apófises; prossoma com fileira longitudinal de tubérculos ao lado do oculário (Fig. 10D) P. sp.n4

Áreas III e IV com tubérculos concentrados na região mediana (entre as apófises) e/ou nos sulcos das áreas; prossoma sem fileira longitudinal de tubérculos (Fig. 8C, D)

7. Áreas III e IV sem tubérculos concentrados na região mediana; estes acompanham os sulcos posteriores destas; tubérculos do escudo dorsal amarelo-claro, com manchas circulares da mesma cor em torno deles (Fig. 8C). P. hatschbachi Áreas III e IV com tubérculos concentrados na região mediana; tubérculos do escudo dorsal amarelo-sulfúreo, destacando-se muito do scudo dorsal pela cor, sem manchas circulares ao redor (Figs. 8D; 19B) 
8. Escudo dorsal com padrão de coloração tigrado de negro; coxa IV densamente tuberculada, sendo os tubérculos de altura semelhante a sua largura (Figs. 8B; 19A) P. difficilis

Escudo dorsal sem padrão de coloração tigrado; coxa IV com poucos tubérculos (menos de dez), mais altos que largos (Figs. 8D; 9A,B)

9. Tergito livre III com um tubérculo espiniforme mediano (Fig. 9A) P. nigripes Tergito livre III liso na região mediana (Fig. 9B). 10

10. Última área do escudo dorsal com fileira horizontal de tubérculos junto ao sulco da margem posterior (Fig. 8D) P.intermedius Última área do escudo dorsal sem fileira horizontal de tubérculos junto ao sulco da margem posterior (Fig. 9B)

P. ornatus

\section{IV.2.2. Caracteristicas gerais e chave para as fêmeas de Promitobates}

As fêmeas seguem o aspecto geral do macho, no que se refere aos padrões de coloração e quantidade e disposição dos tubérculos. Por outro lado, há um grande dimorfismo no comprimento dos fêmures IV, que são extremamente mais longos no macho que na fêmea. No grupo de Mitobatinae que possui apófises na coxa e trocânter IV [clado 2], há também um marcado dimorfismo, com grande redução na armação destes artículos, apresentando-se nas fêmeas apenas como uma apófise espiniforme externa na coxa IV. Além disso, as fêmeas possuem, de um modo geral, o corpo mais convexo que o macho e a armação do oculário, da área III e borda posterior, quando presentes, mais alta e robusta.

1. Oculário armado com um par de tubérculos baixos (Fig. 18B) ................... P. sp.n1 Oculário armado com um par de altas apófises espiniformes (Figs. 18A,C,D) .......... 2

2. Borda posterior do escudo dorsal armada com tubérculos ou apófises espiniformes (Figs. 16B,C,D) 3

Borda posterior do escudo dorsal inerme, somente com fileira de tubérculos de tamanho semelhante (Fig. 16A) P. viridigranulatus

3. Área I do escudo dorsal com poucos tubérculos (menos que 10 em ambas), esparsamente distribuídos; Oculário amarelo-sulfúreo, contrastando fortemente com o restante do corpo (coloração no animal vivo) (Fig. 15A) P. bellus Área I do escudo dorsal densamente tuberculada ou com estes acompanhando o sulco posterior da área (grosseiramente em fileiras); Oculário não contrastando com 
o restante do corpo (da mesma cor ou levemente amarelado) (Figs. 15 B-E; 16C-D) 4

4. Borda posterior armada com um par de pequenos tubérculos (largura semelhante ao comprimento) espiniformes (Figs. 15A, 16C) 5

Borda posterior com um par de altíssimas apófises (muito mais longa que larga) espiniformes (Figs. 15 B,C,E,F; 16D) 6

5 Tergito livre III com apófise mediana; extremidades apicais da coxa e trocânter IV e basal do fêmur IV muito enegrecidos, área IV totalmente recoberta de tubérculos (Fig. 16C) P. sp.n3

Tergito livre III inerme; extremidades apicais da coxa e trocânter IV e basal do fêmur IV semelhante ao restante do segmento, ou levemente enegrecidas, mas nunca em grande contraste com o resto do corpo; Área IV com fileira horizontal de tubérculos junto a margem posterior (Fig. 15D) P. intermedius

6 Áreas III e IV do escudo dorsal densamente tuberculadas, exceto na área em torno das apófises; prossoma com fileira longitudinal de tubérculos ao lado do oculário (Fig. 16D) P.sp.n4

Áreas III e IV com tubérculos concentrados na região mediana e/ou nos sulcos das áreas; prossoma sem fileira longitudinal de tubérculos ao lado do oculário (Figs. 15B, C, E, F)

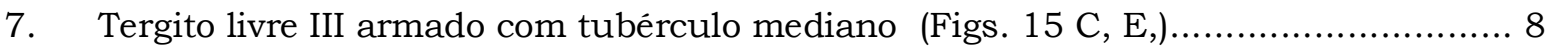

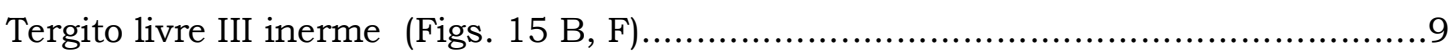

8. Áreas III e IV do escudo dorsal com uma fileira horizontal de tubérculos junto a margem posterior; tubérculos do escudo dorsal amarelo-claro, formando manchas circulares da mesma em torno deles (Fig. 15C) P. hatschbachi Áreas III e IV do escudo dorsal sem fileira fileira horizontal de tubérculos junto a margem posterior; tubérculos do escudo dorsal amarelo-sulfúreo muito destacados, sem manchas circulares ao redor (Fig. 15E). P. nigripes

9. Escudo dorsal com padrão de coloração tigrado de negro; coxa IV densamente tuberculada, sendo os tubérculos arredondados, de altura semelhante a sua largura (Fig. 15B) P. difficilis Escudo dorsal sem padrão de coloração tigrado; coxa IV com poucos tubérculos (menos de dez), mais altos que largos (Fig. 15F). P. ornatus 


\section{Promitobates Roewer, 1913}

(Figuras 8, 9, 10, 11, 12, 13, 14, 15, 16, 17, 18, 19, 20, 21, 22 e 23)

Promitobates Roewer, 1913: 285 (desc.); 1923 (rdesc.): 510; Mello-Leitão, 1923: 163 (rdesc.); 1926: 358 (cit.); 1931a: 141 (cit.); Roewer, 1931b: 108 (cit.); Mello-Leitão, 1932: 400 (cat.; sist.); 1935a: 109; 1937: 293; B. Soares, 1943a: 57; 1944a: 248 (cit.); H. Soares, 1945a: 221 (cit.); Soares \& Soares, 1949: 236 (cat.); Kury, 2003: 151 (cat.) (espécie tipo Ancistrotus hexacanthus Kollar in Koch, 1839, por monotipia).

Neomitobates [part.]: Mello-Leitão, 1922: 343 (desc.); Kury, 2003: 151 (cat.).

Promitobatoides Mello-Leitão, 1927: 21 (desc.); Roewer, 1931: 114 (sist.); MelloLeitão, 1931a: 141; 1932: 403 (cat.); 1935a: 109; Kury, 2003: 151 (cat.). (Espécie tipo Neomitobates ornatus Mello-Leitão, por designação original). Sinonimizado por B. Soares (1943a).

Batomites Mello-Leitão, 1931b: 140 (desc.); 1935a: 27 (sist.); 1935a: 409 (sist.); 1935b: 409 (sist.); 1940a: 29 (sist.); Kury, 2003: 151 (cat). (Espécie tipo Batomites difficilis Mello-Leitão, 1931, por designação original) Sinonimizado por B. Soares (1943a).

Leonardosia Mello-Leitão, 1935a: 28 (desc.); Kury, 2003: 151 (cat.). (Espécie tipo Leonardosia nitida Mello-Leitão, por monotipia). Sinonimizado por B. Soares (1944e).

Espécie-tipo do gênero: Promitobates hexacanthus Kollar in Koch 1939, por monotipia.

\section{Diagnose:}

Promitobates pode ser distinguido dos demais gêneros de Mitobatinae pela borda posterior do escudo dorsal armada com tubérculos ou apófises. Trocânter IV do macho com três apófises dorsais, sendo uma apical, uma basal externa romba e uma pequena apical interna espiniforme; coxa IV do macho com pequena apófise espiniforme interna e apófise externa, bifurcada. Outras características morfológicas podem ser utilizadas em conjunto para distinguir o gênero dos demais Mitobatinae: formato do corpo piriforme; fêmur IV do macho mais que quatro vezes o comprimento do escudo dorsal e trocânter IV do macho 
mais longo do que largo. Promitobates também possui diversas características únicas de genitália masculina, como processo ventral curto (menor que o estilo), ápice do processo ventral com projeção apical cocleariforme e tronco do pênis invadindo grande parte da placa ventral.

Distribuição Geográfica: (Figuras 7A,B,C). BRASIL. Norte de Santa Catarina, Paraná, São Paulo e sul do Rio de Janeiro.

\section{Relações com os outros gêneros de Mitobatinae}

Promitobates forma um grupo monofilético com o gênero Neoancistrotus. Dentre as cinco sinapomorfias que definem o grupo, a presença de uma apófise apical dorsal no trocânter IV dos machos é a mais marcante e de mais fácil reconhecimento. Promitobates + Neoancistrotus formam, por sua vez, um grupo monofilético com o táxon formado pelas quatro espécies de Logiperna + Discocyrtoides nigricans. Esse grande agrupamento possui como principais características a presença de robustas apófises na coxa IV dos machos, tubérculos e/ou apófises nos trocanteres IV e corpo, em ambos os sexos, piriforme, ou seja, a largura do prossoma é sempre menor que a largura do abdômem. 


\section{Promitobates bellus (B. Soares, 1945)}

(Figuras 8A, 11A, 13A, 15A, 17A, 20A, B, C)

Ancistrotellus bellus Soares \& Soares 1945: 260, figs. 8-9 (desc.); 1949: 226 (cat.);

Kury, 2003: 151 (cat.; sist.). [BRASIL, São Paulo, Ubatuba (Fazenda

Experimental); holótipo ô (MZSP 742) e parátipo +(MZSP 748) examinados].

Promitobates bellus: Kury 2003: 151 (cat.; sist).

\section{MACHO}

Diagnose:

Escudo dorsal com poucos tubérculos; tergitos livres lisos. Pode ser facilmente distinguido das demais espécies de Promitobates pelo escudo dorsal com poucos tubérculos e pela coloração da armação do oculário, que é amarelosulfúreo, destacando-se do restante do corpo, que é castanho-escuro uniforme.

Redescrição: Medidas ( $\mathrm{n}=12)$. Escudo dorsal; maior largura: 3,5-4,2; comprimento total: 3,7-4,3; comprimento prossoma: 1,4-1,7. Apêndice IV; comprimento da apófise externa da coxa: 0,7-1,5; comprimento do fêmur: 21,842. Fórmula tarsal: 7-8; 14-18; 8-9; 7-8.

Dorso (Figuras 8A; 11A). Margem anterior do prossoma com elevação mediana granulosa e com 2 a 4 pequenos tubérculos laterais. Prossoma liso, com duas fileiras oblíquas de tubérculos atrás do oculário. Oculário com duas apófises espiniformes de ápice rombo, levemente dirigidas para frente e alguns pequenos tubérculos à frente e atrás destas. Escudo abdominal com quatro áreas. Áreas I e II inermes, com raros e pequenos tubérculos. Área III com duas altas apófises espiniformes levemente direcionadas para trás. Áreas III e IV parcialmente fundidas, com pequenos tubérculos distribuídos medianamente. Borda lateral com uma fileira de tubérculos que inicia na altura da armação do oculário e termina no início da área IV e mais alguns tubérculos esparsos. Borda posterior com uma fileira de tubérculos, dois medianos maiores. Tergitos livres e opérculo anal inermes.

Quelicera. Segmento I com grânulos muito pequenos e esparsos; segmento II liso.

Pedipalpo. Trocânter com elevação dorsal granulosa e um pequeno espinho ventral. Fêmur com um pequeno espinho ventrobasal e um maior, sub-apical, prolateral. Tíbia mesal Iili/Iiili, ectal Iili/IiiIi. Tarso mesal ili; ectal Iili. 
Ventre. Coxa I com uma fileira mediana de cinco tubérculos setíferos maiores, alguns menores esparsos e quatro tubérculos apicais; trocânter I com dois tubérculos medianos. Coxa II com uma fileira mediana de 10 pequenos tubérculos setíferos e três tubérculos apicais; trocânter II com um tubérculo mediano maior e outros menores, esparsos. Coxa III com pequenos tubérculos, distribuídos grosseiramente em fileiras; trocânter III com um tubérculo mediano maior e alguns menores esparsos. Coxa IV com grânulos esparsos, três a quatro tubérculos na margem posterior; área genital com pequenos grânulos esparsamente distribuídos; esternitos livres I-III com uma fileira de grânulos; opérculo anal liso.

Pernas (Figura 13A). Coxa I com uma apófise dorso-basal posterior; coxa II com uma apófise dorso-basal anterior e uma posterior; III com apófise dorsobasal anterior; IV com poucos tubérculos, com apófise apical externa bífida levemente dirigida para trás e internamente com pequeno tubérculo espiniforme. Trocânteres I-III com pequenos tubérculos esparsos; IV com dois tubérculos dorsais, sendo um basal rombo e um apical pontiagudo e uma pequena apófise apical interna espiniforme. Fêmur IV muito longo, reto e inerme, com grânulos baixos e esparsos.

Coloração (em álcool). Escudo dorsal, armação da área III e pernas castanho-escuro; sulcos das áreas do dorso e tubérculos do escudo dorsal amarelo-escuro. Armação e tubérculos do oculário amarelo-claro.

Pênis (Figura 20A, B, C). Placa ventral com laterais convexas, ápice levemente curvado e margens com estrutura arredondada; três setas distais, um par de setas medianas bem menores; três pares de setas basais maiores dipostas em forma de $\mathrm{V}$ e um par de pequenas setas basais ventrais. Estilo liso, de ápice reto e inflado. Processo ventral quase paralelo ao estilo, haste curta, ápice cocleariforme, com longos filamentos voltados para trás.

\section{FÊMEA}

Medidas (n=12) (Figuras 15A; 17A). Escudo dorsal; maior largura: 3,6-4,3; comprimento total: 3,7-4,5; comprimento prossoma: 1,4-1,7. Comprimento do fêmur IV: 10,7-15,1. Fórmula tarsal: 6-7; 14-17; 8; 8.

Diagnose: Corpo mais convexo que o macho. Borda anterior com elevação mediana granulosa; oculário com um par de apófises mais altas que no macho e voltadas para frente. Área III com apófises mais altas e fortes, levemente voltadas 
para trás. Coxa IV com pequena apófise apical externa espiniforme e inerme internamente. Trocânter IV inerme; fêmur IV muito mais curto que no macho.

Distribuição geográfica. (Figura 7B). BRASIL. Mata Atlântica costeira do nordeste de São Paulo e sudeste do Rio de Janeiro.

Material examinado: BRASIL. São Paulo: Ubatuba, (Fazenda Experimental),

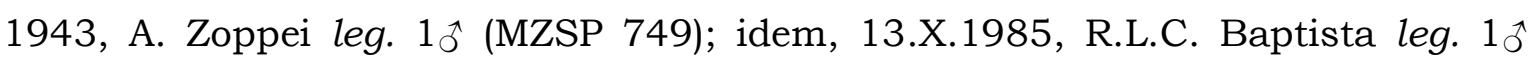
(MNRJ 6107); idem (Fazenda Capricórnio), 1.X.2004, G. Machado leg., 1へર (MZSP 29499); idem, (Moinho Comunitário, Rio da Fazenda), 7.IX.1989, A.B. Kury \& Baptista leg. 1へર e 2 (MNRJ 6513); idem, (Picinguaba), 13-16.X.1994, F.A.G. Mello \& N. Carneiro leg. 1우 (MZSP 17164); idem, 02.IX.2004, 20^ (MZSP 29420); idem, 22. IV.1995, M. Vogt \& M. Baptista leg. 20ิ e 1우 (MNRJ 6921); idem,

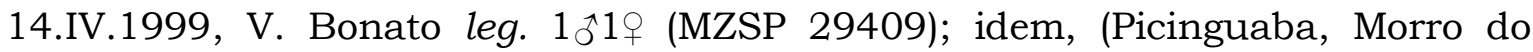
Cuscuzeiro), 22.VII.1995, G. Machado leg. 10へ (MNRJ 5646); idem (Picinguaba), XII.1995, G. Machado leg. 1 $\jmath^{\uparrow}$ e 1 우 (MNRJ 6988); idem (Praia das Toninhas), 0608-III.2000, A.D. Brescovit leg. 3ㅅ e 6 (IB 1736); idem, (Fazenda Angelim,

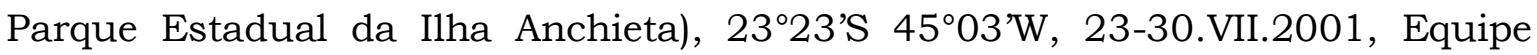
Biota leg.1ô (IB 3306) e 1ㅇ (IB 3343); São Luiz do Paraitinga (Núcleo Santa Virgínia), 2.XI.1996, L.S. Rocha leg. 1 ㅇ (MZSP 15824); Bananal (Serra da Bocaina), 26-27.X.1963, 1 ( (HS 0526); Rio de Janeiro: Parati (Ponta da Joatinga), 16.IV.1997, F.H. Santos leg. $1{ }^{\wedge}$ (MZSP 19509); idem, 01.VI.1985, R.L.C. Baptista leg. 1 (MNRJ 6093); Angra dos Reis (afluente do rio Mambucaba), 2256'14"S 44³6’51”W, XI.2005, M.B. da Silva \& H. Y. Yamaguti leg. 2 ô (MZSP 27396);

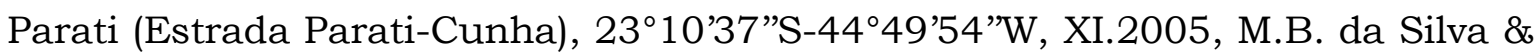
H.Y. Yamaguti leg. 1ð1우 (MZSP 29418). 


\section{Promitobates difficilis (Mello-Leitão, 1931)}

(Figuras 8B, 11B, 13B, 15B, 17B, 19A, 20D,E, F)

Batomites difficilis Mello-Leitão, 1931b: 141, fig. 11 (desc.); 1935a: 109 (cit.); [BRASIL, Santa Catarina; sintipos ô e + (MNRJ 11395) examinados]. Promitobates difficilis: B. Soares, 1945:368 (cat.); Soares \& Soares, 1949b: 237 (cat.); Kury, 2003: 151 (cat.; sist.).

\section{MACHO}

\section{Diagnose:}

Apenas três áreas no escudo dorsal; I com um par de tubérculos maiores; III com um par de apófises afiladas no ápice. Pode ser facilmente diferenciado das demais espécies do gênero pelo padrão de coloração no escudo dorsal com manchas negras, formando um padrão tigrado e pelos tubérculos do prossoma, escudo dorsal e da borda posterior, que são amarelos muito destacados.

\section{Redescrição:}

Medidas ( $\mathrm{n}=7)$. Escudo dorsal; maior largura: 3,9-4,5; comprimento total: 3,9-4,7; comprimento prossoma:1,4-1,9. Apêndice IV; comprimento da apófise externa da coxa: 0,8-1,6; comprimento do fêmur: 15,5-34.3. Fórmula tarsal: 7; $13-16 ; 8-9 ; 8$.

Dorso (Figuras 8B; 11B). Margem anterior do prossoma com elevação mediana provida de pequenos tubérculos e um ou dois tubérculos nas margens laterais. Oculário granuloso, com um par de apófises espiniformes, de ápice rombo, divergentes e dirigidas para frente. Prossoma com tubérculos atrás do oculário formando um "V". Área I com dois tubérculos medianos maiores e outros menores concentrados próximo ao sulco II. Área II com alguns tubérculos próximos ao sulco III e outros restritos às laterais. Áreas III e IV totalmente fundidas, com um par de altas apófises dilatadas na região mediana e alguns tubérculos entre estas, além de uma fileira de tubérculos próximos ao sulco V. Borda lateral com uma fileira de tubérculos que inicia na altura do oculário e termina na área II e com dois a quatro tubérculos bem próximos à margem na altura das áreas II-III. Borda posterior com uma fila de tubérculos que são maiores próximos às margens laterais e dois tubérculos espiniformes na região mediana. Tergitos livres inermes com pequenos tubérculos localizados próximos às margens laterais e região mediana. Opérculo anal inerme. 
Quelicera. Segmento I com dois pequenos tubérculos setiferos; II liso.

Pedipalpo. Trocânter com elevação dorsal granulosa e um pequeno espinho ventral. Fêmur com um pequeno espinho ventral basal um maior sub-apical prolateral. Tíbia mesal Iili; ectal Iili/IIi. Tarso mesal IIi; ectal Iili/IIi.

Ventre. Coxa I com uma fileira mediana de cinco tubérculos setíferos, quatro tubérculos apicais; trocânter I com um tubérculo mediano. Coxa II com uma fileira mediana de oito pequenos tubérculos setíferos e dois tubérculos apicais; trocânter II com um tubérculo mediano. Coxa III com pequenos grânulos setíferos, distribuídos grosseiramente em fileiras e duas fileiras de tubérculos, uma anterior e outra posterior, que se tornam maiores próximos à região distal; trocânter III com um tubérculo mediano. Coxa IV com grânulos esparsos e uma fileira de tubérculos na margem posterior; área genital lisa; esternitos livres com uma fileira de pequenos grânulos; opérculo anal liso.

Pernas (Figura 13B). Coxa I com apófise dorso-basal posterior; coxa II com uma apófise dorso-basal anterior e uma posterior; coxa III com apófise dorsobasal anterior; coxa IV densamente tuberculada, com uma a três pequenas apófises internas e uma apófise apical externa bifurcada, sendo o ramo anterior muito maior que o posterior, voltado para trás, um pequeno tubérculo basal. Trocânteres I-III com pequenos tubérculos esparsos; IV com uma apófise dorsal sub-apical, uma apófise externa basal, além de um pequeno espinho apical interno. Fêmur muito longo, reto e inerme.

Coloração (Figura 19A). Escudo dorsal castanho com manchas negras, formando um padrão tigrado; porção mediana do oculário amarelo; tubérculos do prossoma e escudo dorsal amarelo muito destacados; armação da área III e extremidade apical da coxa IV enegrecidos; quelíceras e pedipalpos castanho esverdeado, reticulado de negro; demais apêndices castanhos, sendo os artículos da perna IV mais escuros.

Pênis (Figuras 20 D, E, F). Placa ventral com laterais pouco convexas, ápice levemente curvado e bordas laterais arredondadas; três setas distais, um par de setas medianas bem menores; três pares de setas basais, em forma de $\mathrm{V}$ e um par de pequenas setas basais, ventrais. Estilo sem cerdas, de ápice reto e inflado. Processo ventral com ápice cocleariforme e filamentos voltados para trás.

\section{FÊMEA.}


Medidas (n=3) (Figuras 15B; 17B). Escudo dorsal; maior largura: 3,9-4,6; comprimento total: 4,1-4,8; comprimento prossoma:1,3-2,0. Apêndice IV; 11,215,5. Fórmula tarsal: $7 ; 13-15 ; 8 ; 8$.

Diagnose: Corpo mais convexo que no macho. Armação da área III muito maiores que no macho e levemente voltada para trás. Borda posterior com um par mediano de longas apófises; tergitos livres inermes. Coxa IV com apófise apical externa reduzida e espiniforme, inerme internamente. Trocânter somente com espinho apical interno; fêmur IV menor que no macho.

Distribuição geográfica. (Figura 7A). BRASIL. Mata Atlântica do norte de Santa Catarina e sudeste do Paraná.

Material examinado: BRASIL. Santa Catarina: Joinville (Serra da Dona Francisca), 12.XII.2007, M.B. da Silva et al. leg. 20̂ e 2 ㅇ (MZSP 27413). Paraná: Morretes, (Porto de Cima), 18.VIII.1988, M.V. Segalla \& Pollati leg. 1ô (MHNCI 6119); (Parque Estadual do Marumbi), 07.II.1988, R.L.C. Baptista leg., $1 \widehat{\jmath}$ (MNRJ 6209); São José dos Pinhais (Usina de Guaricana), 7.VIII.1988, R. Pinto-daRocha, M.V. Segalla \& 0.J.C. Moura-Leite leg. 10^ (MHNCI 6130), Guaratuba (Usina de Guaricana), 04.II.1989, R. Pinto-da-Rocha et al. leg. 2へ e 2 우 (MHNCI 6118); idem (Vila Cubatão), 07.II.1989, R. Pinto-da-Rocha et al. leg. 1우 (MHNCI 6116); idem (Rio Bonito), 2562’32”S - 4854’34”W, XII.2005, M.B. da Silva et al. leg. 5ð̊ (MZSP 27397); Ilha do Mel (Reserva Ecológica), 24.XI.1987, V. Moraes et

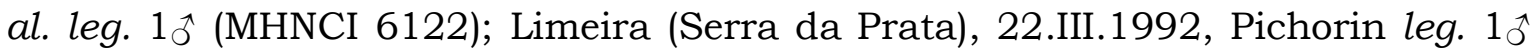
(MZSP 29493); idem, 28.I.1992, 1へิ (MZSP 29445); idem, 28.I.1992, 1ð^1우 (MZSP 29405). 


\section{Promitobates hatschbachi H. Soares, 1945}

(Figuras 8C, 11C, 13C, 15C, 17C, 20G, H, I)

Promitobates hatschbachi H. Soares, 1945a: 219, figs. 4-6 (desc.); Soares \& Soares, 1947a: 66; 1947c: 241 (cit.); 1947b: 211 (cit.); 1947c: 250 (cit.); 1949: 237 (cat.); H. Soares, 1966: 90 (cit.); Pinto-da-Rocha \& Caron, 1989: 1023 (cat.); Pinto-da-Rocha, 1993: 235 (cit.); 1995: 82 (cit.); Kury, 2003: 151 (cat.; sist.). [BRASIL, Paraná; Piraquara: Banhado; holótipo ô (MNHCI 164) e parátipo $q$ (MNHCI 163) examinados].

Promitobates mendax H. Soares 1945: 222, figs. 7-9 (desc.); Soares \& Soares 1945: 368 (cit.); 1947a: 66 (cit.); 1949: 238 (cat.); Pinto-da-Rocha \& Caron: 1989 (cat.); Kury, 2003: 151 (cat.). [BRASIL, Paraná, Barigui; holótipo ô (MNHCI 160) e parátipos đ̂̀ e $q$ (MNHCI 156, 159 e 161) examinados]. Nova sinonimia

\section{MACHO}

\section{Diagnose:}

Escudo dorsal com quatro áreas, III e IV totalmente separadas ou apenas levemente fundidas na região mediana. Borda posterior com um par de apófises pontiagudas medianas, que podem ser muito pequenas ou longas (semelhante ao tamanho das apófises do oculário). Tergito livre III com um apófise espiniforme mediana ou inerme. Espécie próxima às do complexo $P$. ornatus e $P$. difficilis, diferencia-se por um padrão de coloração bastante conspícuo, com os tubérculos e grânulos castanho-claro com um círculo no escudo dorsal da mesma cor em volta destes. Armação do oculário, da área III e tubérculos da borda posterior amarelos.

Redescrição: Medidas ( $\mathrm{n}=6)$. Escudo dorsal; maior largura: 3,6-4,5; comprimento total: 4,2-4,8; comprimento prossoma: 1,7-1,9. Apêndice IV; comprimento da apófise externa da coxa: 0,9-1,6; comprimento do fêmur: 25,546,4. Fórmula tarsal: 8; 13-16; 8-9; 8 .

Dorso (Figuras 8C, 11C) Margem anterior do prossoma com elevação mediana provida de pequenos tubérculos e com um par de tubérculos nas margens laterais. Oculário granuloso, com duas altas apófises de ápice rombo, divergentes e dirigidas para frente, alguns pequenos tubérculos à frente e atrás. Prossoma com tubérculos atrás do oculário formando um "V". Área I com dois 
tubérculos medianos e uma fileira de pequenos tubérculos próximos ao sulco II. Área II com alguns tubérculos irregularmente dispostos. Áreas III e IV totalmente ou parcialmente separadas, sendo a área III com um par de apófises espiniformes de ápice rombo e uma fileira incompleta de tubérculos próxima ao sulco IV. Área IV com dois tubérculos maiores, medianos, e uma fileira de tubérculos. Borda lateral com poucos tubérculos que iniciam na altura do oculário e se estendem de forma descontínua até as áreas III-IV. Borda posterior com uma fila de tubérculos que são pouco maiores próximos às margens laterais e duas apófises espiniformes na região mediana, que podem ser de tamanho variado. Tergitos livres I e II inermes com pequenos tubérculos. Tergito livre III inerme ou com uma apófise espiniforme mediana. Opérculo anal inerme.

Quelicera. Segmento I com dois tubérculos setíferos; segmento II liso.

Pedipalpo. Trocânter com elevação dorsal granulosa e um pequeno espinho ventral. Fêmur com um pequeno espinho ventro-basal e um maior, sub-apical, prolateral. Tíbia mesal IiIi/, ectal IiIi. Tarso mesal IIi; ectal Iili.

Ventre. Coxa I com uma fileira mediana com cinco tubérculos setíferos, três tubérculos apicais e pequenos grânulos setiferos esparsos; trocânter I com dois tubérculos, um mediano e um apical. Coxa II com uma fileira mediana de nove pequenos tubérculos setíferos e dois tubérculos apicais, além de pequenos grânulos setíferos esparsos; trocânter II com um tubérculo mediano e grânulos esparsos. Coxa III com pequenos grânulos setíferos, distribuídos irregularmente em fileiras e uma fileira posterior de tubérculos, que se tornam maiores próximos à região distal; trocânter III com um tubérculo mediano. Coxa IV com pequenos grânulos esparsamente distribuídos e quatro tubérculos na borda posterior; área genital e opérculo anal com pequenos grânulos esparsos; esternitos livres I-III com uma fileira de grânulos.

Pernas (Figura 13C). Coxa I com uma apófise dorso-basal posterior; II com uma apófise dorso-basal anterior e uma posterior; IV com poucos tubérculos altos, com duas a três pequenas apófises espiniformes internas e uma apófise apical externa bifurcada, sendo o ramo anterior maior que o posterior. Trocânter I-III com pequenos tubérculos esparsos; IV com uma apófise dorsal sub-apical, uma apófise externa basal, além de um pequeno espinho apical interno. Fêmur muito longo, reto e inerme.

Pênis (Figura 20 G, H, I). Placa ventral dorsalmente com forte depressão horizontal mediana, laterais convexas, ápice reto e margens laterais com estrutura arredondada; três pares de longas setas distais, um par de setas 
medianas bem menores; três pares de setas basais, em forma de $\mathrm{V}$ e um par de pequenas setas basais no ventre. Estilo liso, reto e de ápice inflado. Processo ventral quase paralelo ao estilo, haste curta, ápice cocleariforme, com longos filamentos voltados para trás.

Coloração (em álcool). Escudo dorsal, quelíceras e pedipalpos castanhoclaro manchados de marrom; tubérculos e grânulos castanho-claro formando, em volta destes, um círculo no escudo dorsal da mesma cor. Armação do oculário, da área III e tubérculos da borda posterior amarelos. Apófise da área III e ápice da apófise externa da coxa IV enegrecidos.

\section{FÊMEA}

Medidas ( $\mathrm{n}=8)$. (Figuras 15C, 17C). Escudo dorsal; maior largura: 4,2-4,7; comprimento total: 3,8-4,9; comprimento prossoma: 1,4-1,8. Comprimento do fêmur IV: 10,2-14,1. Fórmula tarsal: 5-7; 12-15; 8-9; 8-9.

Diagnose: Armação da área III maior que no macho. Borda posterior com um par de altas apófises medianas, pontiagudas e voltadas para trás. Tergitos livres II e III armados com uma apófise espiniforme mediana, tão longa quanto as da borda posterior ou apenas o tergito livre III armado, mas sempre com armação mais longa que no macho. Apófise externa apical da coxa IV reduzida e espiniforme e inerme internamente. Trocânter IV inerme ou com pequeno espinho apical interno; fêmur IV muito mais curto que no macho.

Distribuição geográfica. (Figura 7A). BRASIL. Leste do Paraná e sudeste de São Paulo.

Material examinado: BRASIL. Paraná: Piraquara (Banhado), VI.1944, G.

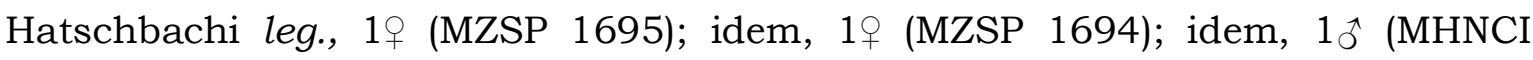
3303); idem, V.1946, C.N. Gofferjé leg. 2̧ e 2 우 (HS 0146); idem, 1ð55우 (MZSP 1019); idem, 13.I.1991, R.Pinto-da-Rocha leg. 1우 (MHNCI 6173); Ypiranga, G. Hatschbachi leg. XII.1944, 1へ̂ (MZSP 1080); Morretes (rio Mãe Catira), W.B. Wosiacki leg, 26.IX.1988, 1ㅇ (MHNCI 6121); idem (Porto de Cima), XI.1948, Gengnagel leg. 1 ㅇ (MNRJ 18798); idem, 29.X.1988, R. Pinto-da-Rocha leg., 1へ (MHNCI 6120); idem (Parque Estadual Marumbi), 6-9.IV.1999, R. Pinto-da-

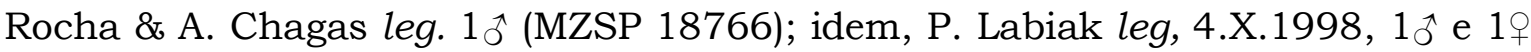
(MZSP 17984); idem (Serra da Prata), M. Bornschein leg, 31.X.1990, 1ㅇ (MHNCI 6809); idem, XII.1945, S. Imaguirei, 1 ㅇ (MHNCI 026); idem (Véu de Noiva), 
8.IV.1999. R. Pinto-da-Rocha leg. 1 iq (MZSP 18811); idem (Rio Taquaral), IX.1945, G. Hatschbachi leg. 1ð1 (MHNCI 1283); São José dos Pinhais (Usina de Guaricana), R. Pinto-da-Rocha et al. leg., 7.VIII.1988, 10 e 1 ㅇ (MHNCI 6114); idem, R. Pinto-da-Rocha et al. leg, 08.III.1999, 1 ㅇ (MNRJ 5802); idem, 4.II.1989, R. Pinto-da-Rocha leg., 1 ô e 1 क (MNRJ 18799); idem, 7.VIII.1988, R. Pinto-daRocha, M.V. Segalla \& J.C. Moura-Leite leg. 1우 e 10 (MHNCI 6114); Barigui,

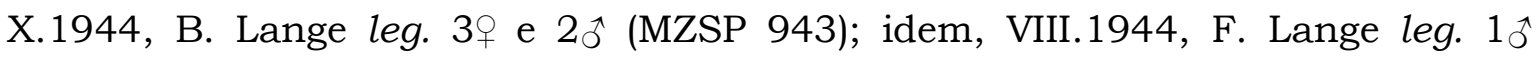
(MZSP 1697); Curitiba, 1948, Gengnagel leg. 1ㅇ (HS 0222); idem, XI.1948, Gengnagel leg. 1 (MNRJ 18797); Boicininga, 19.V.1989, 20 e 2 우 (MHNCI 6526); Curitiba, XI.1948, Gengnagel leg. 1 ㅇ (MNRJ 18797); idem, VIII.1945, C.N. Gofferjé leg. 1つ̂1우 (MZSP 970); Ponta Grossa, (Vila Velha), 5.I.1991, R. Pinto-daRocha, M.M. de Oliveira leg. 1ð^ (MHNCI 6827); Dr. Ulisses (Gruta do Varzeão), R. Pinto-da-Rocha et al. leg. 13-14.X.2000, 1우 (MZSP 18776); Adrianópolis (Rio Ribeira), S. Morato leg. 19.VIII.1989, 20^ (MHNCI 6603); Almirante Tamandaré (Morro Azul), 17.V.1987, R. Pinto-da-Rocha leg. 1ð^ (MHNCI 6127); Quatro Barras (Alto da Serra), 12.VIII.1989, R. Pinto-da-Rocha leg. 10ิ (MHNCI 6609); Campina Grande do Sul (Fazenda Capivari), 1.XI.1990, R. Pinto-da-Rocha leg. 1今2우 (MHNCI 6802); Bocaiúva do Sul (P.E. Campinho), 02.XI.1989, R. Pinto-da-Rocha leg. 10ิ (MHNCI 6666); Rio Branco do Sul (Gruta do Pinheirinho), R. Pinto-daRocha leg., 07.IX.1988, 10ิ (MHNCI 6128); Serra da Graciosa, 10.X.1997, R. Mermudes leg., 10ิ (MZSP 29496); Limeira (Serra da Prata - Guaratuba), 22.III.1992, M. Pichori \& B. Reinert leg., 1ðิ (MZSP 29461); São José dos Pinhais, I.IV.2000, M.A. Rosloski leg., 1 ㅇ (MZSP 679); Turnas do Paraná (próximo Gruta dos Jesuítas), 9-11.VIII.2002, R. Pinto-da-Rocha leg., 10َ (MZSP 29462).São Paulo: Iporanga (P.E. Intervales), B. Buzzato \& B. Requena leg. X.2003, 7ô (MZSP 29450); idem, F. Osses leg. VI.2003, 1ð (MZSP 29452); Apiaí (Fazenda Victoria), A. Masalli leg. 25.XII.1952., 2 (MZSP 29421); idem (Minas de Chumbo), O. Schubart leg., 27.XII.1952, 4ðึ e 2 ㅇ (MZSP 29440). 


\section{Promitobates intermedius (Mello-Leitão, 1935) nova combinação}

(Figuras 8D, 11D, 13D, 15D, 17D, 21A, B, C)

Batomites intermedius Mello-Leitão, 1935a: 409, fig. 31 (desc.); 1935b: 109 (sist.) [BRASIL, São Paulo, "Minas do Iporanga"; 2 síntipos ô (MNRJ 42323) examinados].

Promitobates ornatus (part.); Mello-Leitão, 1922: 343; Roewer, 1931: 114, fig 4; Mello-Leitão, 1932: 404, fig 268.

\section{MACHO}

\section{Diagnose:}

Esta espécie apresenta padrão de ornamentação e coloração do escudo dorsal muito parecido com $P$. ornatus e $P$. nigripes; os tubérculos do escudo dorsal são amarelo-sulfúreos, destacando-se fortemente do corpo castanho escuro uniforme. Distingue-se de $P$. nigripes por possuir o tergito livre III inerme e de $P$. ornatus por possuir as áreas III e IV do escudo dorsal totalmente fundidas e uma fileira de tubérculos junto ao sulco posterior da área IV.

\section{Descrição:}

Medidas $(\mathrm{n}=4)$. Escudo dorsal; maior largura: 5,3-5,4; comprimento total: 4,4-4,6; comprimento prossoma: 1,7-1,8; apêndice IV; comprimento da apófise externa da coxa: 1-1,2 comprimento do fêmur: 41,2-52,1. Fórmula tarsal: 7-8; $14-16 ; 8-9 ; 8$.

Dorso (Figuras 9A, 11E). Margem anterior do prossoma com elevação mediana provida de uma fileira de pequenos grânulos medianos e alguns juntos às laterais. Prossoma com tubérculos que formam um "U" ou "V" atrás do oculário. Oculário com um par de altas apófises espiniformes divergentes e alguns pequenos tubérculos à frente e atrás destas. Área I com um par de tubérculos mais altos e uma fileira junto ao sulco II. Área II com tubérculos ocupando toda a região mediana e extendendo-se até as laterais, junto o sulco III. Áreas III e IV totalmente fundidas, com tubérculos concentrados na região mediana, grosseiramente dispostos em fileiras verticais. Área III com duas altas apófises espiniformes levemente dirigidas para trás. Área IV com um par de tubérculos e uma fileira de tubérculos junto a borda posterior. Borda posterior do escudo dorsal com uma densa fileira de tubérculos, que são levemente maiores próximos às margens laterais e um par de apófises espiniformes medianas. Tergitos livres 
com um pequeno tubérculo nas margens e alguns tubérculos concentrados na região mediana.

Quelicera. Segmentos I e II lisos.

Pedipalpo. Trocânter com um pequeno espinho ventral. Fêmur com um pequeno espinho ventral basal e um maior, sub-apical, prolateral. Tíbia mesal IiIi/iili; ectal Iili. Tarso mesal IIi; ectal Iili/IIi.

Ventre. Coxa I com uma fileira mediana de seis tubérculos setíferos e três tubérculos apicais; trocânter I com um tubérculo mediano. Coxa II com uma fileira mediana de oito pequenos tubérculos setíferos e três tubérculos apicais; trocânter II com dois tubérculos medianos. Coxa III com pequenos grânulos setíferos, distribuídos grosseiramente em fileiras e duas fileiras de tubérculos, uma anterior e outra posterior, que se tornam maiores próximos à região distal; trocânter III com um tubérculo mediano maior e alguns menores, esparsos. Coxa IV com grânulos esparsos e dois tubérculos na margem posterior; área genital, esternitos livres I-III e opérculo anal com pequenos grânulos.

Pernas (Figuras 13E). Coxa I com uma apófise dorso-basal posterior; II com uma apófise dorso-basal anterior e uma posterior; III com uma pequena apófise dorso-basal anterior; IV com poucos e altos tubérculos, com pequena apófise interna e uma apófise apical externa bifurcada, sendo o ramo anterior muito maior que o posterior. Trocânteres I-III com pequenos tubérculos esparsos; IV com uma apófise dorsal sub-apical, uma apófise externa basal, além de um pequeno espinho apical interno. Fêmur muito longo, reto e inerme.

Pênis (Figura 21D, E, F). Placa ventral dorsalmente com depressão horizontal mediana, laterais convexas, ápice reto e margens laterais arredondadas; três setas distais, um par de setas medianas bem menores; três pares de setas basais, em forma de $\mathrm{V}$ e um par de pequenas setas basais ventrais. Estilo liso, reto e de ápice inflado. Processo ventral quase paralelo ao estilo, haste curta, ápice cocleariforme, com longos filamentos voltados para trás.

Coloração. Escudo dorsal castanho escuro, com os tubérculos do escudo dorsal, apófises da borda posterior e do oculário amarelo sulfúreos muito destacados.

\section{FÊMEA}

Medidas (n=3) (Figuras 15E, 17E). Escudo dorsal; maior largura: 5,1-5,2; comprimento total: 4,1-4,2; comprimento prossoma: 1,7-1,8. Comprimento do fêmur IV: 14. Fórmula tarsal: 6; 14; 8; 9. 
Diagnose: Corpo levemente mais convexo que o macho. Borda posterior com um par de altíssimas apófises pontiagudas medianas, voltadas par trás. Tergito livre II com um tubérculo mediano espiniforme ou inerme; III sempre com uma apófise mediana espiniforme. Apófise externa apical da coxa IV reduzida e espiniforme; coxa IV inerme internamente; trocânter IV com pequeno espinho apical interno; fêmur IV de comprimento muito menor que no macho.

Distribuição geográfica. (Figura 7C) BRASIL. Mata Atlântica de São Paulo.

Material examinado. BRASIL. São Paulo. Santo André (Estação Biológica de Paranapiacaba), F. Lane \& B.A.S. Soares leg, 18.III.1943, 2 ㅇ (MZSP 426); idem, 14.VI.1943, 2 q (MZSP 1652); Itanhaém (Cidade Santa Júlia), L.R. Fontes leg.,

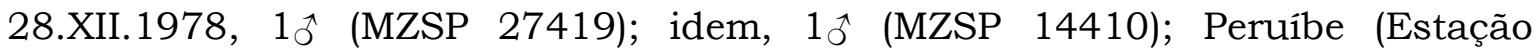
Ecológica Juréia-Itatins), A.D. Brescovit et al. leg. 10.XII.1998, 3ðึ (IB 1436); idem, R. Bertani \& O. Marques leg., XI.1995, 1へิ (IB 751); São Vicente (Horto Florestal), G. Machado leg., 27.X.1996, 3ðิ e 5우 (MZSP 16764); Ribeirão Pires, P.C. Prado leg, III.1935 1우 (IB 104).

Observação: Na descrição da espécie, a localidade está descrita como "Minas do Iporanga", sem definição do município. Imagino se tratar do município de Iporanga, ou área próxima. Entretanto, indivíduos dessa espécie têm os outros registros somente mais ao norte do estado de São Paulo. 


\section{Promitobates nigripes (Mello-Leitão, 1935) nova combinação}

(Figuras 9A, 11E, 13E, 15E, 17E, 21D, E, F)

Neoancistrotus nigripes Mello-Leitão, 1935b: 25, fig 18 (desc.); B. Soares, 1945: 368 (cit.) [BRASIL, São Paulo, Ribeira do Iguape; holótipo ô (MNRJ 41814) examinado].

Ancistrotellus nigripes: Soares \& Soares, 1949: 228 (cat.; sist.); Kury, 2003: 152 (cat.; sist.).

Leonardosia nitida Mello-Leitão, 1935b: 28, fig. 21 (desc.).

Promitobates nitidus: B. Soares, 1944c: 248 (sist.); 1945b: 368 (cit.); Soares \& Soares, 1949: 238 (cat.); Kury, 2003: 152 (cat.; sist.). Sinonimia estabalecida por Soares, 1943.

Promitobates ornatus (part.); Mello-Leitão, 1922: 343; Roewer, 1931: 114, fig 4; Mello-Leitão, 1932: 404, fig 268.

\section{MACHO}

\section{Diagnose:}

Escudo dorsal com tubérculos amarelos muito destacados do corpo castanho escuro uniforme, armação ímpar no tergito livre III e borda posterior do escudo dorsal com um par de apófises espiniformes. Assemelha-se de P. hatschbachi pela armação da borda posterior e armação do tergito livre III, diferenciando-se pelo padrão de ornamentação e coloração do escudo dorsal e é próxima de $P$. ornatus e $P$. intermedius, compartilhando o padrão de coloração, diferenciando-se delas pela armação do tergito livre III.

\section{Descrição:}

Medidas ( $\mathrm{n}=5)$. Escudo dorsal; maior largura: 5,3-5,7; comprimento total: 4,8-4,9; comprimento prossoma: 1,8-1,9. Apêndice IV; comprimento da apófise externa da coxa: 1,2-1,3; comprimento do fêmur: 38,4-53,1. Fórmula tarsal: 6; $15-16 ; 8-9 ; 8$.

Dorso. (Figuras 8D, 11D). Margem anterior do prossoma com elevação mediana provida de pequenos tubérculos medianos, quantos laterais. Prossoma com tubérculos que formam um "V" atrás do oculário. Oculário com um par de altas apófises espiniformes divergentes e alguns pequenos tubérculos atrás destas. Área I com um par de tubérculos mais altos e uma fileira junto ao sulco 
II, que é mais densa próxima ao sulco mediano. Área II com tubérculos que podem ocupar toda a região mediana e extendendo-se até as laterais, junto o sulco III ou ausentes na região mediana. Áreas III e IV parcialmente fundidas, com tubérculos concentrados na região mediana, grosseiramente dispostos em fileiras verticais. Área III com duas altas apófises espiniformes. Área IV com um par de tubérculos e uma fileira de tubérculos junto a borda posterior. Borda posterior do escudo dorsal com uma densa fileira de tubérculos, que são maiores próximos às margens laterais e um par de apófises espiniformes medianas, que podem ser de tamanhos variáveis. Tergitos livres I e II inermes, com um pequeno tubérculo nas margens e alguns tubérculos concentrados na região mediana; III com um pequeno tubérculo espiniforme mediano.

Quelicera. Segmento I com pequeno tubérculo setífero; II liso.

Pedipalpo. Trocânter com um pequeno espinho ventral. Fêmur com um pequeno espinho ventro-basal e um maior, sub-apical, prolateral. Tíbia mesal IiIi/Iiili, ectal IiIi/IiiIi. Tarso mesal iIi; ectal IiIi.

Ventre. Coxa I com uma fileira mediana de seis tubérculos setíferos e três tubérculos apicais; trocânter I com um tubérculo mediano. Coxa II com uma fileira mediana de oito pequenos tubérculos setiferos, quatro tubérculos apicais; trocânter II com dois tubérculos medianos. Coxa III com grânulos setíferos, distribuídos grosseiramente em fileiras e duas fileiras de tubérculos, uma anterior e outra posterior, que se tornam maiores próximos à região distal; trocânter III com um tubérculo mediano maior e alguns menores, esparsos. Coxa IV com grânulos esparsos e dois tubérculos na margem posterior; área genital, esternitos livres I-III e opérculo anal com pequenos grânulos.

Pernas (Figura 13D). Coxa I com uma apófise dorso-basal anterior e uma posterior; II com uma apófise dorso-basal anterior e uma posterior; III com uma pequena apófise dorso-basal anterior; IV com poucos e altos tubérculos, com pequena apófise interna espiniforme e uma apófise apical externa bifurcada, sendo o ramo anterior muito maior que o posterior. Trocânteres I-III com pequenos tubérculos esparsos; IV com uma apófise dorsal sub-apical, uma apófise externa basal, além de um pequeno espinho apical interno. Fêmur muito longo, reto e inerme.

Pênis (Figura 21A, B, C) Placa ventral dorsalmente com depressão horizontal mediana, laterais convexas, ápice reto e margens distais com lateral arredondada; três setas distais, um par de setas medianas bem menores; três pares de setas basais, em forma de $\mathrm{V}$ e um par de pequenas setas basais 
ventrais. Estilo liso, reto e de ápice inflado. Processo ventral menor que o estilo, ápice cocleariforme, com longos filamentos voltados para trás.

Coloração. Escudo dorsal castanho escuro, com os tubérculos do escudo dorsal, apófises da borda posterior e do oculário amarelo sulfúreos muito destacados.

\section{FÊMEA}

Medidas ( $\mathrm{n}=3)$. (Figuras 15D, 17D). Escudo dorsal; maior largura: 4.8-5.1; comprimento total: 4.6-4.8; comprimento prossoma: 1.7-1.8. Comprimento do fêmur IV: 16-23. Fórmula tarsal: 6; 14-16; 8-9; 9.

Diagnose: Corpo levemente mais convexo que o macho. Borda posterior com um par de tubérculos espiniformes medianos. Apófise externa apical da coxa IV reduzida e espiniforme; coxa IV inerme internamente. Trocânter IV com pequeno espinho apical interno; fêmur IV muito menor que no macho.

Distribuição geográfica. (Figuras 7C) BRASIL. Mata Atlântica costeira do Paraná, Mata Atlântica do planalto e interior de São Paulo e Matas Semideciduais do extremo oeste dos estados do Paraná e São Paulo.

Material examinado: BRASIL. São Paulo: Biritiba-Mirim, 29.VIII.2002, 10ิ (MZSP 29451); idem, S. Favorito leg. 15-16.II.2003, 1 우 (MZSP 29431); Pilar do Sul (Fazenda Fibrasil), Weber leg., 1945, 3수 e 5 우 (MZSP 29460); Atibaia (Parque Florestal de Itapetinga), G. Machado leg., 10.VIII.1997, 1へิ (MZSP 29448); idem, 10ิ (MZSP 29449); idem, 1 ( (MZSP 19352); Cananéia (estrada para Itapeti), M.B. da Silva et al leg., 02.II.2006 20ิ (MZSP 27425); idem (Ilha do Cardoso), V.G. Person leg, 23.I.1990, 1 (MHNCI 6691); Barra do Turvo (cachoeira do primeiro Ribeirão - Véu da Noiva), M.B. da Silva et al. leg., 31.I.2006, 30ิ e 19 (MZSP 27427); Miracatu (Morro do Fau), IX. 1999, 1ㅇ (MZSP 27412); idem (Serra de Itimirim), R. Pinto-da-Rocha R.S. Bérnils leg. 20.XII.1998, 10 e 2 ㅇ (MZSP ,17245); Botucatu (Fazenda Morro Vermelho), J. Jim leg, 6.IX.1968, 1ㅅ e 1우 (MZSP 527); Iporanga (Gruta do Moquém), P. Gnaspini leg. 1992, 4ð^ e 3 q (MZSP 14595); idem (Parque Estadual do Alto do Ribeira), R.Indicatti leg, 2122.IX.2002, 2 (IB3098); idem, Exp. MZSP leg, 09-13.X.1992, 1ㅇ (MZSP 17101); Teodoro Sampaio (Parque Estadual do Morro do Diabo), Equipe Biota leg, 0727.III.2003, 1ð (IB 5551); São Paulo (Parque Estadual da Cantareira), R. Pintoda-Rocha et al .leg, 01.V.2001, 20 e 1ㅇ (MZSP 22401 e 22402); idem (Parque 
Estadual do Jaraguá), R. Indicatti leg, 12.XI.2000, 1 ㅇ (IB 1815); Ribeirão Grande (Gruta do Jabaquara), N. Morachiolli leg, 02.VII.2007, 10 (MZSP 27408); Eldorado (Gruta Areia de Baixo), 08.IV.1966, 1 ㅇ (MZSP 9951); idem, 1 ㅇ (MZSP 9953); idem (Caverna do Diabo), E. Izekshon leg, 01.XI.1970, 1우 (MZSP 506); idem, D. Camargo leg, 13.II.1965, 1 ㅇ (MZSP 10001); Pilar do Sul (Fazenda do Linho), W. da Silva leg, XII.1946, 1^ิ (MZSP 21580); Guapiara (Fazenda Intervales), P. Gnaspini leg, 24.X.1991, 10ิ (MZSP 17102); idem, R.J. Sawaya leg, XII.1997, 2 (MZSP 16947); Salto de Pirapora, Rabello leg, 4.II.1968, 1 ( (MZSP 9953); 10 (MZSP 9972).

Paraná: Guaraqueçaba (estrada para Curitiba), M.B. da Silva et al. leg. XII.2005, 3̧ิ e 5ㅇ (MZSP 31029); Guaratuba (Morro Cubatão), R. Pinto-da-Rocha et al. leg, 06.II.1989, 1へર (MHNCI 6117); idem (rio Bonito), M.B. da Silva leg, XII.2005, 1 ㅇ (MZSP27426); idem (Vila Cubatão), R. Pinto-da-Rocha leg, 07.II.1989, 19 (MHNCI 6116); Guairá (Ilha do Cristo), R. Pinto-da-Rocha leg, 3ô e 5 우 (MHNCI s/nº); Ilha do Mel (Reserva Ecológica), S. Caron et al. leg, 14.XI.1989 5ð^ (MHNCI 6123). 


\section{Promitobates ornatus (Mello-Leitão, 1922)}

(Figuras 9B, 11F, 13F, 15F, 17F, 19B, 21G, H, I)

Neomitobates ornatus Mello-Leitão, 1922: 343; 1923: 164, fig. 29 [BRASIL, São Paulo, Alto da Serra; sintipo MZSP 41, sintipo; MZSP 479, 5 sintipos; MZSP 494; 7sintipos, perdidos].

Promitobatoides ornatus: Mello-Leitão, 1927: 22; Roewer, 1931b: 114, fig. 4 (desc.); Mello-Leitão, 1932: 404, fig. 268 (rdesc.).

Promitobates ornatus: B. Soares, 1943a: 56 (sist.); 1944a: 248 (cit.); 1944b: 222 (cit.); 1944c: 177 (cit.); 1944d: 283 (cit.); 1945a: 238 (cit.); 1946: 511 (cit.); H. Soares, 1945a: 224; Soares \& Soares, 1949: 238 (cat.); Kury, 2003: 152 (cat.; sist.).

Batomites spitzi Mello-Leitão, 1931b: 142, fig. 12 (desc.); 1935b: 109 (sist.). [BRASIL, São Paulo: Alto da Serra; holótipo ô (MNRJ11394) examinado]. Sinonímia estabelecida por Soares, 1943.

Batomites heteracanthus Mello-Leitão, 1935b: 27, fig. 20 (desc.). [BRASIL, São Paulo: São Paulo; 2 síntipos $\widehat{o}$ (MNRJ 41810, examinados].

Promitobates heteracanthus: B. Soares, 1945b: 368 (desc.); Soares \& Soares, 1949: 237 (cat.). Sinonímia estabelacida por Kury, 2003.

Promitobates decoratus Mello-Leitão, 1932: 402, fig. 267 (desc.); 1937: 293 (cit.); Soares \& Soares 1949: 237 (cat). [BRASIL, São Paulo: São Sebastião; holótipo ô (MLPC 958/ MNRJ) perdido]. Nova sinonimia

Promitobates margaritatus Roewer, 1931: 109, fig 2 (desc.); Mello- Leitão, 1932: 403 (cat.; sist.); Soares \& Soares, 1949: 237 (cat.); 1970: 339 (cit.); Kury, 2003: 152 (cat; sist.). [BRASIL, Rio de Janeiro: Itatiaia; holótipo ô (SMF RII 1392/3) examinado]. Nova sinonimia

\section{MACHO}

\section{Diagnose:}

Espécie muito próxima de $P$. nigripes e $P$. intermedius, possui os tubérculos do escudo dorsal amarelo sulfúreo, destacando-se fortemente do corpo castanho escuro uniforme. Distingue-se de $P$. nigripes por possuir o tergito livre III inerme e de $P$. intermedius por não apresentar uma fileira de tubérculos na margem da área IV do escudo dorsal. 


\section{Descrição:}

Medidas $(\mathrm{n}=6)$. Escudo dorsal; maior largura: 4,6-5,3; comprimento total: 4,5-4,6; comprimento prossoma: 1,7-1,9. Apêndice IV; comprimento da apófise externa da coxa: 1,1-1,4; comprimento do fêmur: 42,5-47,4. Fórmula tarsal: 6-8; $14-16 ; 8 ; 8$.

Dorso (Figuras 9B, 11F). Margem anterior do prossoma com elevação mediana provida de uma fileira de pequenos tubérculos medianos e um ou dois tubérculos nas margens laterais. Prossoma com tubérculos que formam agrupados atrás do oculário e mais alguns menores, esparsos. Oculário com um par de apófises espiniformes altas e divergentes e alguns pequenos tubérculos a frente e atrás destas. Área I com um par de tubérculos mais altos e uma fileira junto ao sulco II. Área II com tubérculos ocupando toda a região mediana e extendendo-se até quase as laterais, junto o sulco III. Áreas III e IV totalmente separadas, com tubérculos concentrados na região mediana, grosseiramente dispostos em fileiras verticais. Área III com duas altas apófises espiniformes levemente dirigidas para trás. Área IV com um par de tubérculos. Borda posterior com uma densa fileira de tubérculos, que são maiores próximos às margens laterais e um par de pequenas apófises espiniformes medianas. Tergitos livres com um pequeno tubérculo nas margens e fileiras de três a cinco concentrados na região mediana.

Quelicera. Segmento I com 2 tubérculos setíferos; segmento II liso.

Pedipalpo. Trocânter com elevação dorsal granulosa e um pequeno espinho ventral. Fêmur com um pequeno espinho ventral basal e um maior, sub-apical, prolateral. Tíbia mesal Iili/; ectal Iili. Tarso mesal IIi; ectal IiIi/IIi.

Ventre. Coxa I com uma fileira mediana de seis tubérculos setíferos e três tubérculos apicais; trocânter I com um tubérculo mediano. Coxa II com uma fileira mediana de oito pequenos tubérculos setíferos e quatro tubérculos apicais; trocânter II com dois tubérculos medianos. Coxa III com pequenos grânulos setíferos, distribuídos grosseiramente em fileiras e duas fileiras de tubérculos, uma anterior e outra posterior, que se tornam maiores próximos à região distal; trocânter III com um tubérculo mediano maior e alguns menores, esparsos; coxa IV com grânulos esparsos e dois tubérculos na margem posterior; área genital, esternitos livres I-III e opérculo anal com pequenos grânulos.

Pernas (Figura 13F). Coxa I com uma apófise dorso-basal anterior e uma posterior; coxa II com uma apófise dorso-basal anterior e uma posterior; coxa III com apófise dorso-basal anterior; coxa IV com poucos e altos tubérculos, com 
pequena apófise interna e uma apófise apical externa bifurcada, sendo o ramo anterior muito maior que o posterior. Trocânter I-III com pequenos tubérculos esparsos. Trocânter IV com uma apófise dorsal sub-apical, uma apófise externa basal, além de um pequeno espinho apical interno. Fêmur muito longo, reto e inerme.

Pênis (Figura 21G, H, I). Placa ventral dorsalmente com depressão horizontal mediana, laterais convexas, ápice reto e rebordo distal arredondado; três setas distais, um par de setas medianas bem menores; três pares de setas basais, em forma de $\mathrm{V}$ e um par de pequenas setas basais ventrais. Estilo liso, reto e de ápice inflado. Processo ventral quase paralelo ao estilo, haste curta, ápice cocleariforme, com longos filamentos voltados para trás.

Coloração (Figura 19B). Escudo dorsal castanho escuro, com os tubérculos do escudo dorsal, apófises da borda posterior e do oculário amarelo sulfúreos muito destacados.

\section{FÊMEA}

Medidas $(\mathrm{n}=3)$ (Figuras 15F, 17F). Escudo dorsal; maior largura: 4,1-4,3; comprimento total: 4,4-4,6; comprimento prossoma: 1,7-1,8. Comprimento do fêmur IV: 14-16. Fórmula tarsal: 6-8; 14-15; 8; 9.

Diagnose: Corpo mais convexo que o macho. Borda posterior com um par de altas apófises pontiagudas medianas, voltadas par trás. Tergito livre II com uma apófise espiniforme mediana. Apófise externa apical da coxa IV reduzida e espiniforme; coxa IV inerme internamente. Trocânter IV com pequeno espinho apical interno; fêmur IV muito menor que no macho.

Distribuição geográfica. (Figuras 7C) BRASIL. Mata Atlântica costeira de São Paulo e sudeste do Rio de Janeiro.

Material examinado. BRASIL. São Paulo: Santo André (Estação Biológica de Paranapiacaba), R. Pinto-da-Rocha \& S. Casari leg., 25.I.1997 10^^ e 5우 (MZSP

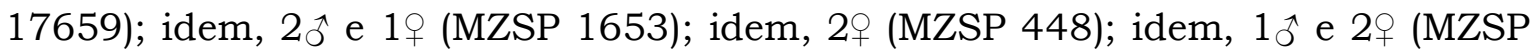
894); idem, 3수 e 5 우 (MZSP 1702); idem, $2 \hat{\jmath}$ e 1 우 (MZSP 1703); idem, C. Rheims \& R. Indicatti leg. 14-16.XII.2003, 10 (IB 4818); idem, R. Pinto-da-Rocha \& S. Casari, XII.1996, 3ðิ e 5ㅇ (MZSP 17633); idem, R. Pinto-da-Rocha et al. leg., 17.V.1998, 2̧ e 4ㅇ (MZSP 16428); idem, 1 ( Rocha et al. leg, 28.XII.1999, 1へิ (MZSP 23595); idem, W. Bokermann leg., 
X.1951, 1̧ึ e 2 ㅇ (MZSP 9977); Salesópolis (Estação Biológica de Boracéia), A.G. Mello leg. 19.XI.1991, 2ð e 1 (

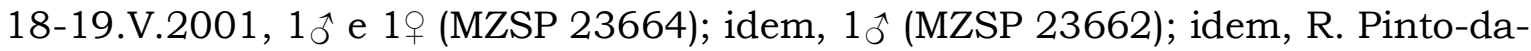
Rocha leg, 30.X.1991, 1 (MZSP 14391); idem, G. Machado \& V. Bonato,

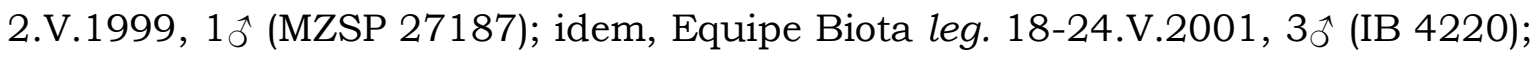
idem, Rabello leg., 2.II.1967, 1ô (MZSP 9974); idem, R. Pinto-da-Rocha et al. leg. 26-28.I.1999, 4ô e 2 ㅇ (MZSP 17607); idem, R. Pinto-da-Rocha et al. leg, 18-

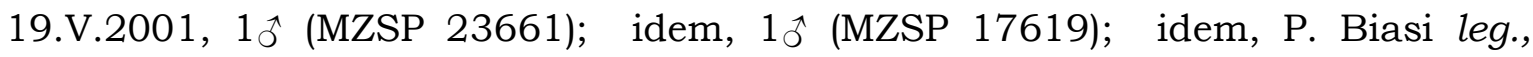
2.IX.1965 10 e 1 ( (MZSP 9986); São Sebastião (Ilhabela), C.R.M. Santos leg., 28.X.1995, 1へર e 1ㅇ (MZSP 17158); idem, G. Machado leg. I.1998, 1へર (MZSP 16678); idem, (Parque Estadual de Ilhabela), Equipe Biota leg. 09-15.X.2001, 1今 (IB 3740); idem, 1 ㅇ (IB 3760); idem (Barra do Una), K. Lenko leg, 03.VII.1961, 2 우 Bertioga (Caiubura), F.A.G. Mello leg. 28.IX.1995, 20ิ e 1우 (MZSP 14401); idem (Guaratuba), F.A.G. Mello leg. 28.IX-10.XI.1995 1ð^ e 1ㅇ (MZSP 17153); Cubatão (Copebrás), C. Bragagnolo et al leg, II-IX.2005, 20^^ e 17우 (MZSP 27441-27460); Cotia (Reserva Morro Grande), A.A. Nogueira et al. leg. III.2003, 4ð̊ (MZSP 25891, 25892, 25893, 25894); idem, A.A. Nogueira et al. leg., VII.2006, 9ð^ e 6 우 (MZSP 27850, 27851, 27852, 27853, 27854, 27855, 27856, 27857, 27858, 27859 e 27860); Guarujá (Morro da praia de Iporanga), M.B. da Silva et al. leg 06.III.2004, 9ð̊ e 1ㅇ (MZSP 22888); Juquitiba (Sítio Boungaville), S. Cunha leg. X. 1996, 1ðิ (IB 775); Miracatu (Fazenda Iterei), Equipe Biota leg. 20-26.IX.2001, 10ิ (MZSP

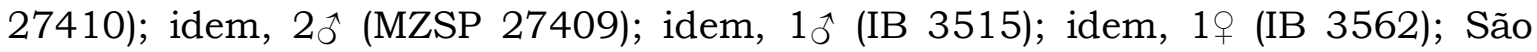
Miguel Arcanjo (Parque Estadual de Carlos Botelho), L.A.M. Mestre leg, 17.II.1997 2へ̂ (MZSP 27422); Ibiúna, T.V. Santos leg, V.1991, 3ㅇ IB 762); Juquiá, J.L. Lima \& J. Damico leg, 12.XII.1941, 1 ㅇ e $1 \hat{\jmath}$ (MZSP 0072). Rio de Janeiro: Angra dos Reis (Lídice), A.B. Kury \& R. Pinto-da-Rocha leg., 01.II.1997, $2 \hat{\jmath}$ (MZSP 29185). 


\section{Promitobates viridigranulatus (Soares \& Soares, 1946)}

(Figuras 9C, 12A, 12B, 14A, 14B, 16A, 18A, 19C, 22A, B, C)

Ancistrotellus viridigranulatus Soares \& Soares 1946: 106, fig. 3 (desc.); 1947a: 79, fig. 10 (desc.); 1947d: 211 (cit.); 1947c: 250 (cit.); 1947e: 211 (cit.); 1949: 230 (cit.); Pinto-da-Rocha \& Caron 1989: 1023 (cat.); [BRASIL, Paraná, Piraquara (Banhado); holótipo ô (MHNCI 3617) examinado].

Promitobates viridigranulatus: Kury 2003: 151 (cat.; sist.).

Promitobates hauseri Silhavý, 1979: 328, figs. 15-21 (desc.); Rambla \& Juberthie, 1994: 221 (cit.); Gnaspini \& Trajano, 1994: 572 (cit.); Pinto-da-Rocha 1995: 81; Kury 2003 (cat.). [BRASIL, São Paulo, Eldorado Paulista (Gruta da Tapagem = Gruta do Diabo); holótipo MHNG, perdido]. Nova sinonimia.

\section{MACHO}

\section{Diagnose:}

Três ou quatro áreas no escudo dorsal, tergitos livros sempre inermes. Espécie com uma grande variação na densidade de granulação no escudo dorsal, podendo ser quase totalmente recobertos por grânulos ou estes apenas concentrados no sulco II, distribuídos homogeneamente na área II $\mathrm{e}$ concentrados na região mediana das áreas III e IV. Essa espécie é facilmente diferenciada pela borda posterior, que é a única entre os Promitobates a não possuir um apr de tubéculos ou apófises espiniformes. Além disso, a coloração única dos grânulos e tubérculos do escudo dorsal, que são de verdes a amarelos.

\section{Redescrição:}

Medidas ( $\mathrm{n}=19)$. Escudo dorsal; maior largura: 3,2-4,4; comprimento total: 3,6-4,6; comprimento do prossoma: 1,5-1,9. Apêndice IV; comprimento da apófise externa da coxa: 0,3-1,3; comprimento do fêmur: 20,3-52,9. Fórmula tarsal: Perna I:6-8; II:14-18; III:7-10; IV:7-10

Dorso (Figuras 9C, 12A, 12B). Margem anterior do prossoma com elevação mediana provida de pequenos grânulos e de dois a quatro tubérculos laterais. Prossoma com tubérculos em forma de "V" ou "U" atrás do oculário e mais alguns tubérculos, que podem ou não estar presentes, distribuídos aleatoriamente pela parte posterior do prossoma. Oculário com duas altas apófises divergentes e alguns pequenos tubérculos atrás destas. Área I com uma fileira de grandes tubérculos junto ao sulco II e pequenos tubérculos de 
densidade variável no restante da área. Área II com uma fileira de tubérculos maiores junto ao sulco III, sendo o restante da área coberta por pequenos tubérculos. Área III com duas altas apófises pontiagudas dirigidas para trás e pequenos tubérculos, que podem ocupar quase que totalmente a área ou concentrar-se na região mediana. Área IV com tubérculos mais concentrados na região mediana e tubérculos, que podem estar distribuídos formando uma fileira junto ao sulco posterior ou concentrados na região mediana. Áreas laterais com uma fileira de tubérculos que seguem do oculário até as áreas II ou III e também grânulos, presentes em densidade variável e distribuídos desde o prossoma até a área IV. Borda posterior com uma fileira de tubérculos, que são maiores próximos às margens laterais. Tergitos livres com uma fileira de tubérculos, que podem ou não ser contínuos e maiores junto às margens laterais. Opérculo anal inerme.

Quelicera. Segmentos I e II lisos.

Pedipalpo. Trocânter com elevação dorsal granulosa e um pequeno espinho ventral. Fêmur com um pequeno espinho ventral basal e um maior, sub-apical, prolateral. Tíbia mesal Iili/Iiili, ectal Iili/Iiili. Tarso mesal IIi; ectal Iili.

Ventre. Coxa I com uma fileira mediana de cinco tubérculos setíferos e dois tubérculos apicais; trocânter I com um tubérculo mediano. Coxa II com uma fileira mediana de sete grânulos setíferos e um tubérculo apical; trocânter II com um tubérculo mediano. Coxa III com pequenos grânulos setíferos, distribuídos grosseiramente em fileiras e duas fileiras de tubérculos, uma anterior e outra posterior, que se tornam maiores próximos à região distal; trocânter III com um tubérculo mediano e grânulos esparsos. Coxa IV com grânulos esparsos e três tubérculos na margem posterior; área genital lisa; esternitos livres I-III com uma fileira de grânulos; opérculo anal com pequenos grânulos.

Pernas (Figuras 14A, 14B). Coxas I-II com uma apófise dorso-basal anterior e uma posterior; III com apófise dorso-basal anterior; com uma pequena apófise interna e uma apófise externa apical bífida, dirigida para trás e com um tubérculo basal. Trocânteres I-III com pequenos tubérculos esparsos; IV do macho com uma apófise dorsal sub-apical e uma externa basal.

Pênis (Figura 22A, B, C). Placa ventral com laterais muito convexas na região mediana, ápice reto; três pares de longas setas distais, igualmente distantes umas das outras quanto ao par de setas medianas, que são menores e mais finas; três a quatro pares de setas basais, em forma de $U$ e um par de pequenas setas basais ventrais. Estilo liso, reto e de ápice inflado. Processo ventral quase 
paralelo ao estilo, haste curta,ápice cocleariforme, com longos filamentos voltados para trás.

Coloração (Figura 19C). Escudo dorsal e armação da área III castanhoescuro. Oculário amarelo-escuro. Tubérculos do escudo dorsal (fileiras junto aos sulcos) entre verdes e amarelos e grânulos do escudo dorsal esverdeados.

\section{FÊMEA.}

Medidas (n=10) (Figuras 16A, 18A). Escudo dorsal; maior largura: 3,3-4,6; comprimento total: 3,8-4,7; comprimento do prossoma: 1,4-2.1. Comprimento do fêmur IV: 10,3-14,9. Fórmula tarsal: 7-8; 15-17; 8-10; 7-8

Diagnose: Corpo tão convexo quanto o macho. Borda anterior pouco granulosa; oculário com um par de altas apófises e apenas um par de tubérculos atrás da armação. Prossoma atrás do cômoro com tubérculos formando um "U". Área I e II inermes, III com um par de apófises, sempre maiores que as do oculário; borda posterior e tergitos livres inermes. Padrão de granulação e coloração semelhante ao macho, apresentando também ampla variação na densidade de grânulos. Coxa IV com pequena apófise apical externa espiniforme e inerme internamente. Trocânter IV inerme; fêmur IV muito menor que no macho.

Distribuição geográfica. (Figura 7A). BRASIL. Mata Atlântica costeira do Paraná e sudeste de São Paulo.

Material examinado: BRASIL. Paraná: Piraquara (Banhado), IV.1946, C.N.

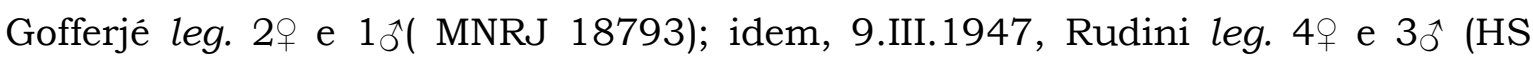
0021); Morretes (Rio Taquaral), XI.1945, G. Hatschbachi leg. 1へર (MHNCI 1280), 1 우 (MHNCI 1281) e 1우 (MHNCI 1282); Marumbi, 17.III.1946, O. Curial leg. 1ऽ (MHNCI 3337); Guaratuba (Rio Bonito) 2356’32”S 4854’34”W, XII.2005, M.B. da Silva et al. leg. 3ð̂ (MZSP 27402); Guaratuba (Usina de Guaricana), 4.II.1989, R.Pinto-da-Rocha \& R. Bérnils leg. 2 e e $1 \overbrace{}^{\Uparrow}$ (MHNC 6113); idem, 5.II.1989, R. Pinto-da-Rocha leg. 2ર (MHNCI 6112); idem, 8.III.1999, A. Kury, R. Pinto-daRocha \& A. Giupponi leg. 3 (MZSP 18128); idem, III.1999, A. Kury et al. Leg. 3 ㅇ e 2ో (MNRJ5816); Limeira (Serra da Prata), 22.III.1992, M. Pichorin \& B. Reinert leg., 1ð1우 (MZSP 29468); São José dos Pinhais (Usina de Guaricana), 8.VIII.1998, R. Pinto-da-Rocha \& Moura Leite leg. 2へ (MNRJ 6545); idem, 8.III.1999, A. Kury, R. Pinto-da-Rocha \& A. Giupponi leg. 39 e 1̧̊ (MNRJ 5803); 
Guaraqueçaba (Tagaçaba), 15.IV.1989, M. Bornschein leg. 1ð^ (MHNCI 6527); São Paulo: Cananéia (Serra do Itapitangui, estrada para Ariri), 2459'18"S

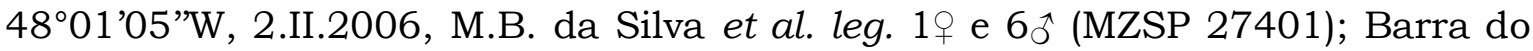
Turvo (pé da Serra do Cadeado) 2454'49”S 48¹4'45’W, 1.II.2006, M.B. da Silva

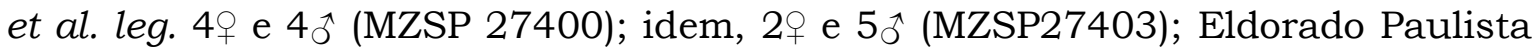
(Gruta da Tapagem = Gruta do Diabo), 18.XI.1991, L. Trajano leg,1ð1우 (MNRJ 18794); Iguape (Ilha do Cardoso), 19.IV.1991, M.V. Segalla leg., 1ð1 (MZSP 29497). 


\section{Promitobates sp.n1}

(Figuras 10A, 12C, 14C, 16B, 18B, 19D, 22D, E, F)

Material-tipo: BRASIL. Santa Catarina: São Bento do Sul (Ano Bom), 26²2'S 49¹3W, 3.IV.1999, R. Pinto-da-Rocha \& R. Bérnils leg. holótipo ô; parátipos 4 ㅇ e $3 \widehat{o}$ (MZSP 18635).

\section{MACHO}

Diagnose: Compartilha com Promitobates sp.n2 a armação externa da coxa IV que se apresenta como uma apófise curta e não bifurcada. Entretanto, é facilmente distinguivel desta pela armação do oculário, com apenas com dois tubérculos, tergito livre II com armação par e coloração do dorso e apêndices amarelo pontilhado de negro.

Descrição: Medidas ( $\mathrm{n}=10)$. Escudo dorsal; maior largura: 3,8-4,4; comprimento total: 4,1-4,3; comprimento prossoma: 1,6-1,7. Apêndice IV; comprimento da apófise externa da coxa: 0,9-1,4; comprimento do fêmur:16,118,9. Fórmula tarsal: 7; 15-16; 8-10; 9-10.

Dorso (Figuras 10A, 12C). Margem anterior do prossoma lisa com elevação mediana inerme. Prossoma liso, com dois a quatro pequenos tubérculos atrás do oculário. Oculário com dois tubérculos rombos e mais quatro pequenos tubérculos atrás dos olhos. Área I com dois tubérculos medianos próximos ao sulco posterior e alguns pequenos tubérculos próximos ao sulco mediano e posterior. Área II com pequenos tubérculos esparsamente distribuídos. Área III e IV parcialmente fundidas, III com um par de apófises pontiagudas, dilatadas na região mediana e levemente dirigidas para trás, alguns pequenos tubérculos distribuídos antes e próximos ao sulco posterior. Áreas laterais totalmente inermes. Borda posterior com uma fileira de tubérculos espiniformes, sendo maiores os próximos às margens laterais e com duas pequenas apófises pontiagudas medianas. Tergitos livres I e II e placa anal inermes e tergito III com um par de apófises espiniformes.

Quelicera. Segmento I com dois tubérculos setíferos; segmento II liso.

Pedipalpo. Trocânter com elevação dorsal granulosa e um pequeno espinho ventral. Fêmur com um pequeno espinho ventral basal e um maior, apical, prolateral. Tíbia mesal IiIi/, ectal IiIi. Tarso mesal IIi; ectal Iili. 
Ventre. Coxa I com uma fileira mediana de cinco tubérculos setíferos e dois tubérculos apicais; trocânter I com um tubérculo mediano. Coxa II com uma fileira mediana de oito pequenos tubérculos setíferos e dois tubérculos apicais; trocânter II com um tubérculo mediano. Coxa III com pequenos grânulos setíferos, esparsamente distribuídos e duas fileiras de tubérculos, uma anterior e outra posterior, que se tornam maiores próximos à região distal; trocânter III com um tubérculo mediano e alguns grânulos esparsos. Coxa IV com grânulos esparsos e quatro tubérculos na margem posterior; área genital lisa; esternitos livres I-III com uma fileira de grânulos; opérculo anal com pequenos grânulos esparsos.

Pernas (Figura 14C). Coxa I com apófise dorso-basal posterior; coxa II com uma apófise dorso-basal anterior e uma posterior; coxa III inerme; coxa IV com poucos tubérculos, com um a três tubérculos espiniformes apicais internos e uma apófise apical externa, curta, dirigida para trás e com um tubérculo basal. Trocânter I-III com pequenos tubérculos esparsos. Trocânter IV com duas apófises dorsais externas, sendo a basal romba. Fêmur IV longo, reto e inerme.

Pênis (Figura 22D, E, F). Placa ventral com laterais convexas, ápice reto; três pares de longas setas dispostas sub-apicalmente, um par de setas medianas levemente menores; três pares de setas basais, em forma de $\mathrm{V}$ e um pequeno par de setas basais ventrais. Estilo liso, levemente curvado. Processo ventral quase paralelo ao estilo, ápice cocleariforme, com filamentos voltados para trás.

Coloração (Figura 19D) Escudo dorsal amarelo pontilhado de negro; quelíceras, pedipalpos, coxa e trocânter I a III amarelo-escuro; demais artículos castanho-claro; armação da área III e extremidade apical da apófise externa da coxa IV enegrecidos.

\section{FÊMEA.}

Medidas (n=9) (Figuras 16B, 18B). Escudo dorsal; maior largura: 4,1-4,8; comprimento total: 4,1-4,7; comprimento do prossoma: 1,5-1,7. Comprimento do fêmur IV: 10,6-12,6. Fórmula tarsal: 6; 13-16;10; 8-10

Diagnose: Corpo mais convexo que o macho. Borda posterior da área IV sempre lisa. Tergito livre II com apenas um pequeno par de pequenos tubérculos ou inerme; tergito livre III com um par de apófises espiniformes. Coxa IV com pequena apófise apical externa espiniforme e inerme internamente. Trocânter IV inerme; mais curto que no macho; fêmur IV de comprimento muito menor que no macho. 
Distribuição geográfica. (Figura 7A). BRASIL. Mata Atlântica do norte de Santa Catarina e sudeste do Paraná.

Material examinado: BRASIL. Santa Catarina: Campo Alegre, 25.III.1993, R. Sachsse \& S. Potsch leg. 1へ̂ (MNRJ 6892); Joinville (Serra Dona Francisca),

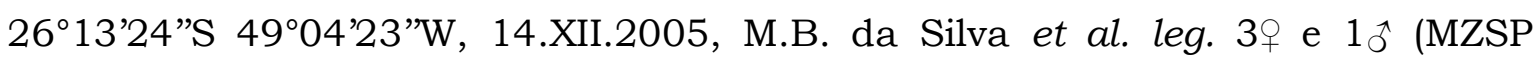
27405); idem, 13.XII.2005, M.B. da Silva et al. leg. 2 e e $3 \hat{\jmath}$ (MZSP 27404); São

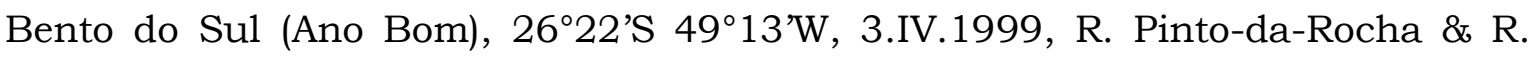
Bérnils leg. 10ิ (MZSP 18649); idem, 4ㅇ e 3ð̊ (MZSP 18635). Paraná: São José dos Pinhais (Usina de Guaricana), 28.IV.1987, R. Bérnils leg. 1ð઼ (MHNCI 6129); idem, 16.II.1988, R. Pinto-da-Rocha leg. 19 e $1 \hat{\jmath}$ (MNRJ 18796). 


\section{Promitobates sp.n2}

(Figuras 10B, 12D, 14D, 22G, H, I)

Material-tipo: BRASIL. São Paulo: Cotia (Reserva Morro Grande), VII.2008, R. Pinto-da-Rocha et al. leg; holótipo ô (MZSP 31197).

\section{MACHO}

Diagnose: Compartilha com $P$. sp.n1 a presença de uma apófise externa da coxa IV curta e não bifurcada e assemelha-se a $P$. hatschbachi e $P$. ornatus pelo padrão de granulação do escudo dorsal. Entretanto, distingue-se pela coloração, com escudo dorsal, quelíceras, pedipalpos e pernas I a III castanho-claro e extremidade apical da coxa IV, trocânter IV e extremidade basal do fêmur IV muito enegrecidos.

Descrição. Medidas (n=2). Escudo dorsal; maior largura: 4,3-4,5; comprimento total: 4,2; comprimento prossoma: 1,8. Apêndice IV; comprimento da apófise externa da coxa: 0,95; comprimento do fêmur: 34,8-37,6. Fórmula tarsal: 7-8; 15-16; 10; 8-9.

Dorso (Figuras 10B, 12D). Margem anterior do prossoma com elevação mediana granulosa e dois a três tubérculos nas margens laterais. Oculário com duas altas apófises eretas e alguns tubérculos a frente e atrás. Prossoma com tubérculos atrás do oculário, formando um "U”. Área I com uma fileira de pequenos tubérculos junto ao sulco posterior e dois tubérculos maiores, medianos. Área II com uma fileira de tubérculos junto ao sulco posterior e mais alguns esparsos. Áreas III e IV fundidas, III com duas apófises longas, pontiagudas, eretas, alguns tubérculos concentrados no centro a acima e dois tubérculos maiores abaixo. Margens laterais com uma fileira de tubérculos junto ao sulco que inicia na altura do prossoma e termina na área II e dois tubérculos próximos à borda na altura da área II. Margem posterior com dois tubérculos espiniformes medianos e uma fileira de tubérculos rombos que inicia junto às apófises medianas e são progressivamente maiores junto às margens laterais. Tergitos livres I e II com pequenos tubérculos e um par maior junto às margens laterais; III com um tubérculo espiniforme mediano.

Quelicera. Segmento I com três tubérculos setíferos; segmento II liso.

Pedipalpo. Trocânter com um pequeno espinho ventral. Fêmur com um pequeno espinho ventral basal e um maior, sub-apical, prolateral. Tíbia mesal IiIi; ectal Iili. Tarso mesal IIi; ectal IIi. 
Ventre. Coxa I com uma fileira mediana de seis tubérculos setíferos e dois tubérculos apicais; trocânter I com um tubérculo mediano e poucos grânulos esparsos. Coxa II com uma fileira mediana com oito pequenos tubérculos setíferos e dois tubérculos apicais; trocânter II com um tubérculo mediano. Coxa III com pequenos grânulos setíferos, distribuídos grosseiramente em fileiras e duas fileiras de tubérculos, uma anterior e uma posterior, que se tornam maiores próximos à região distal; trocânter III com um tubérculo mediano e grânulos esparsos. Coxa IV com grânulos esparsos e três tubérculos na margem posterior; área genital lisa; esternitos livres I-III com fileira de tubérculos; opérculo anal com poucos grânulos.

Pernas. (Figura 14D). Coxa I-II com uma apófise dorso-basal anterior e uma posterior; coxa III com apófise dorso-basal anterior; coxa IV com altos tubérculos, apófise apical externa curva, voltada para trás e com um tubérculo basal e com uma a duas pequenas apófises espiniformes internas. Trocânter I-III com pequenos tubérculos esparsos. Trocânter IV com duas apófises dorsais externas, uma apical e uma basal romba e um pequeno espinho apical interno. Fêmur IV muito longo, reto e inerme.

Coloração. Escudo dorsal, quelíceras, pedipalpos e pernas I a III castanhoclaro. Extremidade apical da coxa IV, trocânter IV e extremidade basal do fêmur IV enegrecidos.

Pênis (Figura 22G, H, I). Placa ventral dorsalmente com depressão horizontal mediana, laterais convexas, ápice reto e margens laterais arredondadas; três pares de setas distais, um pequeno par de setas medianas; três pares de setas basais, em forma de $\mathrm{V}$ e um par de pequenas setas basais ventrais. Estilo liso, reto e de ápice inflado. Processo ventral quase paralelo ao estilo, ápice cocleariforme, com filamentos voltados para trás.

FÊMEA. Desconhecida.

Distribuição geográfica. (Figura 7B). Conhecido apenas da localidade-tipo.

Material examinado: BRASIL. São Paulo: Cotia (Reserva Morro Grande), 15.XII.2002, A. A. Nogueira et al. leg. 20ิ (MZSP 27406); idem, VII.2008, R. Pinto-da-Rocha et al. leg. 1へ( (MZSP 31197). 


\section{Promitobates sp.n3}

(Figuras 10C, 12E, 14E, 16C, 18C, 23A, B, C)

Material-tipo: BRASIL. São Paulo: Ribeirão Pires (Gruta da Quarta Divisão), 20.VIII.1992, E. Trajano \& P. Gnaspini leg.; holótipo đ̂ e 2 parátipos đึ? (MZSP 17161.

\section{MACHO}

Diagnose: Assemelha-se à $P$. sp.n2 pela coloração do escudo dorsal, quelíceras, pedipalpos e pernas I a III castanho-claro e extremidade apical da coxa IV, trocânter IV e extremidade basal do fêmur IV muito enegrecidos, distinguindo-se desta pela apófise bifurcada da coxa IV e padrão de ornamentação do escudo dorsal, que é por sua vez, muito semelhante à $P$. viridigranulatus, com fileiras de tubérculos seguindo os sulcos das áreas I-III e restante das áreas bastante granulosa. Diferencia-se desta pela coloração e armação da borda posterior, que em $P$. viridigranulatus é inerme e $P$. sp.n3 possui um par de tubérculos medianos espiniformes.

Descrição: Medidas $(\mathrm{n}=2)$. Escudo dorsal; maior largura: 4,6-5,3; comprimento total: 5,3-5,7; comprimento prossoma: 2,2. Apêndice IV; comprimento da apófise externa da coxa: 1,2-1,4; comprimento do fêmur: 48,856,1. Fórmula tarsal: 9; 16; 11; 10-12.

Dorso (Figuras 10C, 12E). Margem anterior do prossoma com elevação mediana com uma fileira de pequenos tubérculos. Prossoma com tubérculos formando um "U" ou "V" atrás do oculário. Oculário com duas altas apófises espiniformes, de ápice rombo e dois pares de pequenos tubérculos atrás destes. Área I com duas fileiras de tubérculos maiores junto ao sulco II e pequenos tubérculos no restante da área. Área II altamente tuberculada, sendo maiores os da fileira junto ao sulco III. Área III e IV totalmente separadas. Área III com duas altas apófises, afiladas no ápice, voltados para cima e pequenos tubérculos que ocupam totalmente a área. Área IV dividida por um sulco transversal, totalmente recoberta por tubérculos. Áreas laterais com uma fileira de tubérculos próxima ao sulco, que seguem do oculário até o sulco da área II e mais alguns tubérculos bem próximos à margem do escudo. Borda posterior com dois a três tubérculos próximos às margens laterais e um par de tubérculos espiniformes medianos. Tergitos livres com uma fileira de tubérculos. Opérculo anal inerme.

Quelicera. Segmento I com dois tubérculos setíferos; segmento II liso. 
Pedipalpo. Trocânter com elevação dorsal granulosa e um pequeno espinho ventral. Fêmur com um pequeno espinho ventral basal e um maior, sub-apical, prolateral. Tíbia mesal Iili/, ectal IiIi. Tarso mesal IIi; ectal IIi.

Ventre. Coxa I com uma fileira mediana de cinco tubérculos setíferos, dois tubérculos apicais e grânulos esparsamente distribuídos; trocânter I com um tubérculo mediano. Coxa II com uma fileira mediana de seis pequenos tubérculos setíferos e dois tubérculos apicais, além de alguns grânulos esparsos; trocânter II com um tubérculo mediano. Coxa III com pequenos grânulos setíferos, esparsamente distribuídos e duas fileiras de tubérculos, uma anterior e outra posterior, que se tornam maiores próximos à região distal; trocânter III com um tubérculo mediano maior e alguns menores, esparsos. Coxa IV com grânulos esparsos e quatro tubérculos espiniformes na margem posterior. Área genital lisa; esternitos livres I-III com uma fileira de tubérculos; opérculo anal com pequenos grânulos.

Pernas (Figura 14E). Coxa I com apófise dorso-basal anterior; coxa II com uma apófise dorso-basal anterior e uma posterior; coxa III inerme; coxa IV com poucos e altos tubérculos; duas pequenas apófises internas espiniformes e uma apófise externa apical bífida, dirigida para trás e com um tubérculo basal. Trocânter I-III com pequenos tubérculos esparsos. Trocânter do macho com uma apófise dorsal sub-apical, uma externa basal e um espinho apical interno. Fêmur IV reto, muito longo e inerme.

Coloração (em álcool). Escudo dorsal e armação da área III castanhoescuro. Oculário amarelo-escuro. Tubérculos do escudo dorsal (fileiras junto aos sulcos) entre verdes e amarelos e grânulos do escudo dorsal esverdeados.

Pênis (Figura 23A, B, C). Placa ventral dorsalmente com laterais convexas, ápice levemente curvado e bordas laterais com estrutura arredondada; três pares de setas distais, um par de setas medianas bem menores; três pares de setas basais, em forma de V e um par de pequenas setas basais ventrais. Estilo liso, reto e de ápice inflado. Processo ventral quase paralelo ao estilo, ápice cocleariforme, com filamentos voltados para trás.

\section{FÊMEA.}

Medidas ( $\mathrm{n}=1)$ (Figuras 16C, 18C). Escudo dorsal; maior largura: 5,3; comprimento total: 5,7; comprimento prossoma: 2,1. Comprimento do fêmur IV: 15,1. Fórmula tarsal: $7 ; 15 ; 10 ; 11$. 
Diagnose: Oculário com um par de tubérculos a frente da armação. Apófises da área III mais altas e cilindricas que no macho. Áreas III-IV apenas parcialmente divididas. Tergito livre III com uma apófise espiniforme mediana. Apófise externa da coxa IV reduzida e espiniforme. Trocânter IV inerme, com pequenos grânulos. Coxa IV com pequena apófise apical externa espiniforme e inerme internamente. Trocânter IV inerme; fêmur IV de comprimento muito menor que no macho.

Distribuição geográfica. (Figura 7B). Conheicdo apenas da localidade-tipo.

Material examinado: BRASIL. São Paulo: Ribeirão Pires (Gruta da Quarta Divisão), 20.VIII.1992, E. Trajano \& P. Gnaspini leg. 20ิ e 1우 (MZSP 17161). 


\section{Promitobates sp.n4}

(Figuras 10D, 12F, 14F, 16D, 18D, 19E, 23D, E, F)

Material-tipo: BRASIL, Rio de Janeiro, Jacarepaguá; holótipo ỗ (MNRJ 04545).

\section{MACHO}

\section{Diagnose:}

Prossoma com tubérculos que uma fileira longitudinal de cada lado do oculário. Corpo densamente granuloso, sendo a área I totalmente preenchida por tubérculos ou estes menos a circundando a área. Distingui-se de $P$. sp.n3 pela coloração marrom homogênea com os tubérculos amarelos muito destacados e das espécies do complexo $P$. ornatus pela densidade e disposição dos tubérculos.

\section{Descrição:}

Medidas $(\mathrm{n}=4)$. Escudo dorsal; maior largura: 3,7-4,2; comprimento total: 3,9-4,6; comprimento prossoma: 1,4-1,7. Apêndice IV; comprimento da apófise externa da coxa: 0,8-1,2; comprimento do fêmur: 21,7-38,4. Fórmula tarsal: 6-8; 4-16; 8-9; 8 .

Dorso (Figuras 10D, 12F). Margem anterior do prossoma com elevação mediana provida de uma fileira de pequenos tubérculos até às margens laterais. Prossoma com tubérculos formando um "U" atrás do oculário, uma fileira longitudinal de tubérculos ao lado do oculário e outros menores, distribuídos aleatoriamente pelo prossoma. Oculário com um par de altas apófises espiniformes divergentes e alguns pequenos tubérculos atrás destas. Área I com uma fileira de tubérculos que acompanha toda a margem da área ou esta sendo totalmente preenchida por tubérculos. Área II altamente granulosa. Área III com duas altas apófises espiniformes e muitos tubérculos, mais concentrados na região mediana e nas margens da área. Área IV com tubérculos mais concentrados na região mediana uma fileira junto ao sulco posterior. Áreas laterais com uma fileira de tubérculos maiores que seguem do oculário até a área II e outros menores, presentes em grande densidade e distribuídos desde o prossoma até a área IV. Borda posterior com uma densa fileira de tubérculos, que são maiores próximos às margens laterais e um par de apófises espiniformes medianas. Tergitos livres com uma fileira de tubérculos. Opérculo anal inerme.

Quelicera. Segmento I com 2 tubérculos setíferos; segmento II liso. 
Pedipalpo. Trocânter com elevação dorsal granulosa e um pequeno espinho ventral. Fêmur com um pequeno espinho ventral basal e um maior, sub-apical, prolateral. Tíbia mesal Iili/; ectal Iili. Tarso mesal IIi; ectal Iii/Ii.

Ventre. Coxa I com uma fileira mediana de quatro tubérculos setiferos e três tubérculos apicais; trocânter I com um tubérculo mediano. Coxa II com uma fileira mediana de nove pequenos tubérculos setíferos e três tubérculos apicais; trocânter II com dois tubérculos medianos. Coxa III com pequenos grânulos setíferos, distribuídos grosseiramente em fileiras e duas fileiras de tubérculos, uma anterior e outra posterior, que se tornam maiores próximos à região distal; trocânter III com um tubérculo mediano maior e alguns menores, esparsos. Coxa IV com grânulos esparsos e quatro tubérculos na margem posterior; área genital, esternitos livres I-III e opérculo anal com pequenos grânulos.

Pernas (Figura 14F). Coxa I com uma apófise dorso-basal posterior; coxa II com uma apófise dorso-basal anterior e uma posterior; coxa III com apófise dorso-basal anterior; coxa IV com poucos e altos tubérculos, com pequena apófise interna e uma apófise apical externa bifurcada, sendo o ramo anterior muito maior que o posterior. Trocânter I-III com pequenos tubérculos esparsos. Trocânter IV com uma apófise dorsal sub-apical, uma apófise externa basal, além de um pequeno espinho apical interno. Fêmur muito longo, reto e inerme.

Pênis (Figura 23D, E, F). Placa ventral dorsalmente com depressão horizontal mediana, laterais convexas, ápice reto e margens laterais com estrutura arredondada; três setas distais, um par de setas medianas bem menores; três pares de setas basais, em forma de 'V" e um par de pequenas setas basais ventrais. Estilo liso, reto e de ápice inflado. Processo ventral quase paralelo ao estilo, ápice cocleariforme, com longos filamentos voltados para trás.

Coloração (Figura 19E). Escudo dorsal castanho escuro uniforme, com os tubérculos e armação do oculário, da área III e tubérculos do escudo dorsal amarelo sulfúreo.

\section{FÊMEA}

Medidas ( $\mathrm{n}=1)$ (Figuras 16D, 18D). Escudo dorsal; maior largura: 4.3; comprimento total: 4.8; comprimento prossoma: 1.8. Comprimento do fêmur IV: 14. Fórmula tarsal: $6 ; 14 ; 8 ; 9$.

Diagnose: Corpo mais convexo que o macho. Oculário com um par de apófises espiniformes pouco maiores que no macho, e apenas dois pares de tubérculos atrás e um par a frente. Área II totalmente recoberta por grânulos; 
apófises da área III maiores que no macho. Borda posterior com um par de altas apófises pontiagudas medianas, voltadas par trás. Tergito livre II com uma pequena apófise espiniforme mediana. Apófise externa apical da coxa IV reduzida e espiniforme; coxa IV inerme internamente. Trocânter IV com pequeno espinho apical interno; fêmur IV inerme e reto, de comprimento muito menor que no macho.

Distribuição geográfica. (Figura 7B). Mata Atlântica costeira de São Paulo e sudeste do Rio de Janeiro

Material examinado: BRASIL. São Paulo: Miracatu (Morro do Fau), 19.XII.1999, R. Pinto-da-Rocha et al. leg. 10 1q (MZSP 17047); Jacupiranga, 3.XI.1973, J. Jim leg. 10ิ (HS 0507); Pariquera-Açú, 10 (MNRJ 17.668); São Sebastião (Praia do Camburi), VI.1995, E.C. Capri leg., 10ิ (IBSP 757); idem (CEBIMAR), 7.I.1992, R.L. Baptista leg., 10ิ (MNRJ 6836); idem (Baraqueçaba), 5.I.1994, R.L. Baptista leg., 2へ( (MNRJ 4863);

Observação: A localidade-tipo, Jacarepaguá, refere-se à um exemplar depositado no MNRJ, identificado como "P. granulosissimus, holótipo", cuja etiqueta original do lote consta apenas a informação "Promitobates jacarepaguá". Nesta etiqueta não há mais nehuma outra fonte de informação, quanto ao responsável pela identificação, ano ou localidade. $O$ holótipo de $P$. granulosissimus é uma fêmea, não sendo coespecífico com este material. 


\section{Species inquirendae}

\section{Promitobates granulosissimus Mello-Leitão, 1932}

Promitobates granulosissimus Mello-Leitão, 1932: 401, fig. 266 (desc.); Soares \& Soares 1949: 237 (cat.); Kury, 2003: 151 (cat.). [BRASIL, São Paulo, São Sebastião; holótipo ổ (MLPC 0959) perdido].

O holótipo de $P$. granulosissimus é uma fêmea e a ilustração é de baixa qualidade. A descrição aproxima essa espécie com as espécies do complexo $P$. ornatus. No entanto, apenas com a descrição de uma fêmea e sem a posse do holótipo, é impossível a determinação da espécie.

\section{Promitobates hexacanthus (Kollar in Koch, 1839)}

Ancistrotus hexacanthus Kollar in Koch 1839: 48, pl. 226, fig 560 (desc.); Kury, 2003: 151 (cat.; sist.). [BRASIL, "Paraná, Rio Negro"; holótipo ô NHMW, perdido] Goniosoma hexacanthum: Simon, 1879: 233 (desc.)

Promitobates hexacanthus: Roewer 1913: 286, fig. 114 (desc.); 1923: 510, fig. 637 (rdesc); Mello-Leitão 1932: 401, fig. 265 (rdesc); Soares \& Soares 1949: 237 (cat.)

$\mathrm{Na}$ descrição da espécie, não há nenhuma informação adicional sobre a localidade-tipo, indicando apenas a nacionalidade. O holótipo, um único exemplar macho, foi depositado na coleção Imperial dos Habsburgos, em Viena. Roewer (1913), em visita à Viena, examinou material de um outro lote, identificado como "Ancistrotus armatus sp.n”., este sim, procedente de Rio Negro, e julgou ser a mesma espécie de Kollar. Durante o andamento do presente trabalho, foi possivel analisar slides de $P$. hexacanthus, gentilmente cedido pelo curador da instituição. Entretanto, na etiqueta, a data de coleta com registro da localidade "Rio Negro" é incompatível com a descrição da espécie (1847 e 1839, respectivamente). Portanto, conclui-se que o material lá depositado não se refere ao utilizado por Kollar na descrição da espécie mas muito provavelmente, à $A$. armatus, identificado por Roewer como $P$. hexacanthus, não se tratando, 
portanto, do material-tipo da espécie. A descrição original não fornece informações suficientes para uma identificação confiável, principalmente sem posse do material-tipo da espécie. 


\section{CONCLUSÕES}

1. Mitobatinae é um grupo monofilético sustentado por cinco sinapomorfias, sendo quatro delas exclusivas: comprimento do fêmur IV dos machos muito maior que o comprimento do escudo dorsal (> 4 vezes); fêmur IV dos machos sem fileiras ventrais de tubérculos ou espinhos e tíbia IV dos machos maior do que duas vezes o comprimento do escudo dorsal.

2. Mitobatinae é grupo-irmão de Despirus parvulus e composto por dois grandes clados; um grupo que possui corpo grosseiramente retangular e machos e fêmeas possuem a coxa e o trocânter IV inermes, ou com apófises muito reduzidas e um segundo grupo que apresenta corpo grosseiramente piriforme e dimorfismo sexual na coxa e trocânter IV, com os machos apresentando principalmente forte armação externa na coxa e apófises no trocânter.

3. Das dez espécies nominais de Promitobates, quatro são consideradas válidas: $P$. bellus, $P$. hatschbachi, $P$. ornatus e $P$. viridigranulatus.

4. Três sinonímias são propostas, $P$. hauseri é considerado sinônimo de $P$. viridigranulatus, $P$. margaritatus sinônimo de $P$. ornatus e $P$. mendax sinônimo de $P$. hatschbachi.

5. P. granulosissimus e $P$. hexacanthus são consideradas species inquirendae.

6. Com base nos resultados da análise cladística, o complexo polimórfico $P$. ornatus é separado em três espécies nominais, sendo que $B$. intermedius e N. nigripes são revalidadas.

7. Quatro espécies novas são descritas: Promitobates sp.n1 (localidade-tipo: Ano Bom, Santa Catarina); Promitobates sp. n2 (localidade-tipo: Reserva Morro Grande, São Paulo); Promitobates sp.n3 (Localidade-tipo: Ribeirão Pires, Sãom Paulo) e Promitobates. sp.n4 (Localidade-tipo: Jacarepaguá, Rio de Janeiro). 


\section{REFERÊNCIAS BIBLIOGRÁFICAS}

Acosta, L.E.; Pérez-Gonzáles, A. \& Tourinho, A.L. 2007. Methods and techniques of study: Methods for taxonomic study. In: Pinto-da-Rocha, R.; Machado, G. $\&$ Giribet, G. (Eds). Harvestmen. The Biology of Opiliones. Harvard University Press, Massachusetts. 595 pp.

Acosta, L.E. 2001. The identity of Acrographynotus erictispina, with a review of the generic diagnosis, and the description of a new species (Opiliones, Gonyleptidae, Pachylinae). Bulletim of the British American Arachnological Society, 12(2): 58-66.

Amorim, D.S. 1982. Classificação por sequenciação: uma proposta para a denominação dos ramos retardados. Revista Brasileira de Zoologia 1(1): 1-9.

Bremer, K. 1994. Branch support and tree stability. Cladistics, 10: 295-304.

Coddington, J. \& Scharff, N. 1994. Problem with zero-lengh branches. Cladistcs, 10:415-423.

Campbell, J.A. \& Frost, D.R. 1993. Anguid lizards of the genus Abronia: Revisionary notes, descriptions, of four new species, a phylogenetic analysis, and a key. Bulletim of the American Museum of Natural History, 216: 1-121.

Chappil, J.A. 1989. Quantitative characters in phylogenetics analysis. Cladistics, 5: 217-234.

Chu, P.C. 1998. A phylogeny of the Gulls (Aves: Larinae) inferred from osteological and integumentary characters. Cladistcs 14: 1-43.

Da Silva, M.B. 2002. Análise filogenética e biogeográfica de Goniosomatinae (Arachnida, Opiliones, Gonyleptidae). ix + 192 pp. Dissertação de Mestrado, Universidade de São Paulo, São Paulo.

Da Silva, M.B. 2008. Biogeografia de opiliões Gonyleptidae na Mata Atlântica, com revisão sistemática de Hernandariinae (Arachnida, Opiliones). Tese de Doutorado. Universidade de São Paulo, São Paulo.

De Pinna, M.C.C. 1991. Concepts and tests of homology in the cladistcs paradigm. Cladistics, 7:367-394.

Dunlop, J.A. 2007. Paleontology. In: Pinto-da-Rocha, R.; Machado, G. \& Giribet, G. (Eds). Harvestmen. The Biology of Opiliones. Harvard University Press, Massachusetts. 595 pp 
Gnaspini, P. \& Trajano, E. 1994. Brazilian cave invertebrates, with a checklist of troglomorphic taxa. Revista Ibérica de Entomologia, 38(3/4): 549-584.

Goloboff, P. A. 1993b. Estimating character weights during tree search. Cladistics, 9: 83-91.

Goloboff, P. A. 1997. Self-Weighted Optimization: Tree Searches and character State Reconstruction under Implied Transformation Costs. Cladistics, 13: 225- 245.

Goloboff, P. A., 1998. NONA. Versão 2.0. Programa de computador disponível na página da internet: www.cladistics.com/dta

Goloboff, P. A., J. S. Farris \& Nixon, K. C. 2003. T.N.T: Tree Analysis Using New Technology. Program and documentation, available from the authors, and at www.zmuc.dk/public/phylogeny.

Grant, T. \& Kluge, A.G. 2003. Data exploration in phylogenetic inference: scientific, heuristic, or neither. Cladistics, 19: 379-418.

Kornet, D.T. \& Turner, H. 1999. Coding Polymorphism for Phylogeny Reconstruction. Systematic Biology, 48(2): 365-379.

Kury, A.B. 1989a. A new species of Discocyrtoides (Opiiones: Gonyleptidae: Bourguyiinae). Bulletim of the British American Arachnological Society, 8(1):9-12.

Kury, A.B. 1989b. Notes on Mitobatinae III: A remarkable new Brazilian species of Mitobates Sund., 1833 (Opiliones: Laniatores: Gonyleptidae). Boletim do Museu Nacional do Rio de Janeiro, 328:1-12.

Kury, A.B. 1990a. Synonymic notes on Mitobates Sund. With redescription of the type species $M$. conspersus (Perty) (Opiliones: Gonyleptide). Bulletim of the British American Arachnological Society, 8(6) 194-200.

Kury, A.B. 1990b. Notes sur les Mitobatinae II. Redescription de Ancistrotellus bipustulatus Mello-Leitão. Revue arachnologique, 9(4):49-56.

Kury, A.B. 1991a. Application 2.759. Goniosoma conspersum Perty December 1833 (currently Mitobates conspersus; Arachnida, Opiliones): Proposed precedence over Mitobates triangulus Sundervall, April 1833. Bulletin of Zoological Nomenclature, 48(2): 105-106.

Kury, A.B. 1991b. Notes on Mitobatinae IV: Ischnoterus tenebrosus new genus and new species of Brazilian harvestmen (Opiliones: Laniatores: Gonyleptidae). Mitteilungen aus dem Zoologisches Museum in Berlin, 67(2): 351-359. 
Kury, A.B. 1991c. Notes on Mitobatinae V: Revalidation of Ruschia, with redescription of the type species (Opiliones: Laniatores: Gonyleptidae). Bulletim of the British American Arachnological Society, 8(9): 284-287.

Kury, A.B. 1992a. Notes on Mitobatinae VI. A review of Metamitobates Roewer (Opiliones, Gonyleptidae, Mitobatinae). Mitteilungen aus dem Zoologisches Museum in Berlin, 68(1): 157-166.

Kury, A. B. 1992b. The genus Spinopilar Mello-Leitão, 1940, with notes on the status of the family Tricommatidae (Arachnida, Opiliones). Steenstrupia, 18(5): 93-99.

Kury, A. B. 1994a. On the identity of the enigmatic Leptocnema Koch (Arachnida, Opiliones, Gonyleptidae). Mitteilungen aus dem Zoologisches Museum in Berlin, 70(1): 93-98.

Kury, A.B. 1994b. Early lineages of Gonyleptidae (Arachnida, Opiliones, Laniatores). Tropical Zoology, 7: 343-353.

Kury, A. B. 1995. A review of Mitopernoides revalidated (Progonyleptoidellinae) and the synonymy of Mitoperna with Neosadocus (Gonyleptinae, Arachnida, Opiliones). Papéis Avulsos de Zoologia, 39(8): 201- 207.

Kury, A. B. 1997. The genera Saramacia and Syncranaus Roewer, with notes on the status of the Manaosbiidae (Opiliones, Laniatores, Gonyleptoidea). Boletim do Museu Nacional do Rio de Janeiro, 374: 1-22.

Kury, A.B., 2000. A review of Cnemoleptes (Arachnida, Opiliones, Gonyleptidae). Boletim do Museu Nacional, N.S. Zoologia, Rio de Janeiro, 420: 1-6.

Kury, A.B. 2003. Annotated catalogue of the Laniatores of the New World (Arachnida, Opiliones). Revista Ibérica de Aracnología, vol. especial monográfico, 1:1-337.

Kury, A. B. \& Pinto-da-Rocha, R. 1997. Notes on the Brazilian harvestmen genera Progonyleptoidellus Piza and Iporangaia Mello-Leitão (Opiliones, Gonyleptidae). Revista brasileira de Entomologia, 41(1): 109-115.

Mabee, P.M. \& Humphries, J. 1993. Coding polymorphic data: Examples from allozymes and ontogeny. Sysematic Biology, 42: 166-181.

Machado, G.; Pinto-da-Rocha, R. \& Giribet, G. 2007. What are harvestmen? In: Pinto-da-Rocha, R.; Machado, G. \& Giribet, G. (Eds). Harvestmen. The Biology of Opiliones. Harvard University Press, Massachusetts. 595 pp.

Mayr, E.. 1969. Principles of systematic zoology. New York: McGraw Hill. 416 pp. Mello-Leitão, C.F. de. 1922. On some new Brazilian Gonyleptidae. Annals and Magazine of Natural History, 9: 329-348. 
Mello-Leitão, C.F. de. 1923. Opiliões Laniatores do Brasil. Arquivos do Museu Nacional do Rio de Janeiro, 24: 107-197.

Mello-Leitão, C. F. de. 1926. Notas sobre Opiliones Laniatores sul-americanos. Revista do Museu Pauista, 14: 327-383.

Mello-Leitão, C.F. de. 1927 Gêneros novos de Gonyleptideos (Nota previa). Boletim do Museu Nacional do Rio de Janeiro, 3(2): 137-142.

Mello-Leitão, C. F. de. 1931a. Opiliões colligidos por E. Moraes Mello em Pinheiro (Rio de Janeiro). Boletim do Museu Nacional do Rio de Janeiro, 7(2): 93-96.

Mello-Leitão, C. F. de. 1931b. Quatro novos opiliões. Boletim do Museu Nacional do Rio de Janeiro, 7(2): 115-119.

Mello-Leitão, C.F. de. 1932. Opiliões do Brasil. Revista do Museu Paulista. 17(2): $1-505$.

Mello-Leitão, C.F. de. 1934. Novos Gonyleptidae da coleção do Instituto Butantan. Memórias do Instituto Butantan, 8: 409-417.

Mello-Leitão, C. F. de. 1935a. A propósito de alguns opiliões novos. Memórias do Instituto Butantan, 9: 369-411.

Mello-Leitão, C. F. de. 1935b. Alguns novos opiliões do Estado de S. Paulo e do Districto Federal. Archivos do Museu Nacional do Rio de Janeiro, 36: 9-37.

Mello-Leitão, C. F. de. 1937. Alguns opiliões da colecção do Instituto Butantan. Memórias do Instituto Butantan, 11: 275-288.

Mello-Leitão, C. F. de. 1940a. Sete gêneros e vinte e oito espécies de Gonyleptidae. Archivos de Zoologia do Estado de São Paulo, 1(1): 1-52.

Nixon, K.C. 1999. Winclada (BETA) ver. 0.9.9. Publicado pelo autor, Ithaca, New York, USA.

Nixon, K.C. \& Davis, J.I. 1991. Polymorphic taxa, missing values and cladistic analysis. Cladistics. 7: 233-241.

Nixon, K.C. \& J.M. Carpenter. 1993. On outgroups. Cladistics, 9: 413-426.

Page, R. D. M. 2001. Nexus Data Editor 0.5.0., available at http://taxonomy.zoology.gla.ac.uk/rod/rod.html Pimentel, R.A. \& Riggins, R. 1987. The nature of cladistic analysis. Cladistics, 3(3): 201-209.

Pinto-da-Rocha, R. \& Caron, S. 1989. Catálogo do Material-tipo da coleção de Arachnida Rudolf Bruno Lange do Museu de História Natural "Capão da Imbuia", Curitiba, Paraná. Brasil. Revista Brasileira de Biologia, 49(4): 1021-1029. 
Pinto-da-Rocha, R. \& Kury, A.B. 2003. Third species of Guasiniidae (Opiliones, Laniatores) with comments on familial relationships. Journal of Arachnology, 31: 394-399.

Pinto-da-Rocha, R., da Silva, M.B. \& Bragagnolo, C. 2005. Faunistic similarity and biogeography of the harvestmen of Southern and Southeastern Atlantic rain forest of Brazil. Journal of Arachnology, 33: 290-299.

Pinto-da-Rocha, R.; Machado, G. \& Giribet, G. 2007. Harvestmen. The Biology of Opiliones. Harvard University Press, Massachusetts. 595 pp.

Pinto-da-Rocha, R. 1993. Invertebrados cavernícolas da porção meridional da Província Espeleológica do Vale do Ribeira, sul do Brasil. Revista Brasileira de Zoologia, 10(2): 229-255.

Pinto-da-Rocha, R. 1995. Sinopse da fauna cavernícola do Brasil (1907 - 1994). Papéis Avulsos de Zoologia, 39(4): 61-173.

Pinto-da-Rocha, R. 1997. Systematic review of the family Stygnidae (Opiliones: Laniaores: Gonyleptoidea). Arquivos de Zoologia, 33(4): 163-342.

Pinto-da-Rocha, R. 2002. Systematic review and cladistic analysis of the Brazilian subfamily Caelopyginae. Arquivos de Zoologia., 36:357-364.

Prendini, L. 2001. Species or supraspecific taxa as terminals in cladística analysis? Groundplans versus exemplars revisited. Systematic Biology, 50: 290-300.

Rambla, M. \& Juberthie, C. 1994. Opiliones. In: C. Juberthie \& V. Decu (eds.), Encyclopaedia Biospeologica, I: 215-230.

Roewer, C.F. 1913. Die Familie der Gonyleptiden der Opiliones-Laniatores. Archiv für Naturgeschichte, 79A(4): 1-472.

Roewer, C.F. 1923. Die Weberknechte der Erde. Systematische Beardeitung der bisher bekannten Opiliones. Gustav-Ficher, Jena, 1116pp.

Roewer, C.F. 1931. Weitere Weberknechte V. (5. Ergänzung der Weberknechte der Erde, 1923). Abhandlumgen Naturwissevischaftlichen Verein Zu Bremen, 28(2-3): 101-164.

Schultz, J. 1990. Evolutionary morphology and phylogeny of Arachnida. Cladistics, 6(1): 1-38.

Šilhavý, V. 1979c. Opilionids of the suborder Gonyleptomorphi from the American caves, collected by Dr. Pierre Strinati. Revue Suisse Zoologie, 86(2): 321-334.

Thiele, K. 1993. The holly grail of the perfect character: the cladistic treatment of morphometric data. Cladistics 9: 275-304. 
Simmons, N.B. \& Geisler, J.H. 2002. Sensitivity analysis of different methods of coding taxonomic polymorphism: an example from higher-level bat phylogeny. Cladistics 18: 571-584.

Simon, E. 1879. Essai d'une classification des Opiliones Mecostethi. Annales of Societe de Entomologique Belgique, 22: 183-241.

Smith, E.N., Gutberlet Jr., R.L. 2001. Generalized frequencies coding: a method for preparing polymorphic multistate characters for phylogenetic analysis. Systematic Biolology, 50: 156-169.

Smouse P.E, Dowling, T.E, Tworek, J.A, Hoeh, W.R \& Brown, W.M. 1991. Effects of intraspecific variation on phylogenetic inference: a likelihood analysis of mtDNA restriction site data in cyprinid fishes. Systematic Zoology, 40: 393409.

Soares, B. A. M. \& H. E. M. Soares, 1945. Novos opiliões do Departamento de Zoologia da Secretaria de Agricultura do Estado de São Paulo. Papéis Avulsos Departamento de Zoologia do Estado de São Paulo, 5(27): 251-270.

Soares, B.A.M. \& Soares, H.E.M. 1946. Novos opiliões de Banhado (Estado do Paraná). Papéis Avulsos Departamento de Zoologia do Estado de São Paulo, $7(8): 101-111$.

Soares, B.A.M. \& Soares, H.E.M. 1947a. Alótipos e novas formas de opiliões Paranaenses. Papéis Avulsos Departamento de Zoologia do Estado de São Paulo, 8(5): 63-84.

Soares, B.A.M. \& Soares, H.E.M. 1947b. Opiliões paranaenses da coleção Joram Leprevost (Opiliones - Gonyleptidae). Papéis Avulsos Departamento de. Zoologia do Estado de São Paulo, 8(12): 137-144.

Soares, B.A.M. \& Soares, H.E.M. 1947c. Opiliões da coleção Gofferjé. Papéis Avulsos Departamento de Zoologia do Estado de São Paulo, 8(21): 249-259.

Soares, B.A.M. \& Soares, H.E.M. 1947d. Nova espécie de Ubatubesia Soares, 1945 e alótipo de Wygodzinskyia viridiornata Soares et Soares, 1945 (Opiliones - Gonyleptidae). Papéis Avulsos Departamento de Zoologia do Estado de São Paulo, 8(6): 85-88.

Soares, B.A.M. \& Soares, H.E.M. 1947e. Opiliões pertencentes à coleção Gert Hatschbach (Opiliones - Gonyleptidae, Phalangodidae, Phalangiidae). Papéis Departamento de Zoologia do Estado de São Paulo, 8(18): 209-230.

Soares, B.A.M. \& Soares, H.E.M. 1949. Monografia dos gêneros de opiliões neotrópicos II. Arquivos de Zoologia do Estado de São Paulo, 7(2): 151-239. 
Soares, B.A.M. 1943. Notas sobre opiliões IV. Boletim da Indústria Animal N.S., 6(3): 53-58.

Soares, B.A.M. 1944a. Notas sobre opiliões V-XIII. Papéis Departamento de. Zoologia do Estado de São Paulo, 4(17): 243-276.

Soares, B.A.M. 1944b. Opiliões do Alto da Serra. Papéis Departamento de. Zoologia do Estado de São Paulo, 4(16): 221-242.

Soares, B.A.M. 1944c. Mais alguns opiliões de Boracéa. - Papéis Avulsos Departamento de Zoologia do Estado de São Paulo, 4(12): 177-186.

Soares, B.A.M. 1944d. Opiliões do Alto da Serra II. Papéis Avulsos Departamento de Zoologia do Estado de São Paulo, 4(18): 277-302.

Soares, B.A.M. 1945a. Revisão dos opiliões do Instituto Butantã. Papéis Avulsos Departamento de Zoologia do Estado de São Paulo, 5(25): 227-242.

Soares, B.A.M. 1945b. Opiliões da coleção do Museu Nacional do Rio de Janeiro. Archivos de Zoologia do Estado de São Paulo, 4(9): 341-394.

Soares, B.A.M. 1946. Opiliões do Departamento de Zoologia. Revisão dos opiliões existentes atualmente no Departamento de Zoologia da Secretaria da Agricultura do Estado de São Paulo. Archivos de Zoologia do Estado de São Paulo, 4(13): 485-534.

Soares, H.E.M. 1945. Contribuição ao estudo dos opiliões do Paraná. Papéis Avulsos Departamento de Zoologia do Estado de São Paulo, 4(24): 207-230

Soares, H.E.M. 1966. Opiliões da coleção Gofferjè (Opiliones: Gonyleptidae, Phalangodidae). Papéis Avulsos Departamento de Zoologia do Estado de São Paulo, 18(10): 87-102.

Stevens, P.F. 1991. Character states, Morphological variation, and phylogenetical analysis: a review. Systematic Botany 16(3): 553-583.

Strong, E.E. \& Lipscomb, D. 1999. Character coding and inapplicable data. Cladistics, 15:363-371.

Sundevall, C.J. 1833. Conspectus Arachnidum. 39pp. London. C.F. Berling

Vrana, P. \& Wheeler, W. 1992. Individual organisms as terminal entities: Laying the species problem to rest. Cladistics 8: 67-72.

Wiens, J.J. \& Servedio, M.R. 1997. Accuracy of phylogenetic analysis including and excluding polymorphic characters. Systematic Biology, 46: 332-345.

Wiens, J.J. 1995. Polymorphic characters in phylogenetic systematics. Systematic Biology, 44:482-500.

Wiens, J.J. 1999. Polymorphism in systematics and comparative biology. Ann. Rev. Ecol. Syst., 30: 327-362. 
Wiens, J.J. 2000. Coding Morphological Variation within species and higher taxa for phylogenetic analysis. In: Wiens, J.J. (Ed.). Phylogenetic Analysis of Morphological Data. Smithsonian Institution Press. Washington DC, pp. 115-145.

Yamaguti, H.Y \& R. Pinto-da-Rocha, 2009. Taxonomic review of Bourguyiinae, cladistic analysis, and a new hypothesis of biogeographic relationships of the Brazilian Atlantic Rainforest (Arachnida: Opiliones, Gonyleptidae), Zoological Journal of the Linnean Society, 156, 319-362. 
Ampycus 2

Ancistrotellus.....4, 6, 67, 80, 88, 107

Ancistrotus $2,5,65,103$

Asarcus $2,4,20$

Batomites $.5,61,65,70,77,84$

Bourguyia. $16,17,19,20$,

$21,27,29,30,35,36,38,41,42$, 43,52

B. albiornata 17,19 , 20, 21, 23, 25, 27, 29, 30, 35, 36, $37,38,40,41,42,43,52$

B. laevibuna. 20

Bourguyiinae 2, 20,37, 107, 113

Bugabitia 3, 4

Caelopygus ... 17, 19, 20,

$24,27,28,30,32,36,37,38,40$, 42,44

C. elegans.. $15,17,19$, $20,24,27,28,30,32,36,37,38$, $40,42,43,44$

Cnemoleptes 4

Cobania picea. 15

Cranaus 2

Cyphophthalmi. 1 Despirus 4, 18, 21, $25,26,32,34,35,43,49,105$ D. parvulus .18, 21, 25, 26, 32, 33, 34, 35, 36, 43, 49, 55, 105 Discocyrtoides $4,15,17,19$, $25,36,37,42,46,48,49,50,53$,
D. nigricans...15, $17,19,27,44,48$ Discocyrtus... $15,17,18$ $28,38,42,43,46$

D. testudineus . $15,20,24,37$

Dyspnoi 1

Encheiridium 4, 17, 18, 19, $26,28,32,41,48,49,50,53,54$, 55

E. montanum. 50

E. ruschii... $17,18,19,49$

Eupnoi 1

Goniosoma 2, 103, 107

Gonyleptidae $1,14,20,21$, 22, 29, 37, 106, 107, 108, 109, $111,112,113$

Iporangaia. 4 Ischnotherus $4,15,23,26,33$, $37,38,41,45,48,50,53,54$ Laniatores 1, 3, 6, 107, 108, 109, 110 Leonardosia. $5,65,80$ Leptocnema.... 2 Leptocnemus 4 Longiperna 4,15 , $16,17,24,25,30,32,33,34,36$, $37,38,41,42,46,48,49,50,53$,

L. cancellata............ 15, 16, 24, 48

L. concolor........ 16, 17, 30, 46, 48

L. insperata............ 17, 25, 40, 41

L. coxalis......17, 27, 32, 33, 34, 38 
Metamitobates... $2,4,15,16$, $18,19,21,25,26,27,37,38,41$, $46,50,53,108$ M. squalidus 15 , $16,21,25,27,37,38,46$ Metaroeweria. 4 Metasarcus. 2,4

Mitobates 2,4 $15,17,18,19,21,22,23,25,26$, 27, 29, 39, 41, 44, 46, 48, 49, 50, 53, 55, 107 M. conspersum 2,107

M. inermis $19,21,29$

M. pulcher 15,25

M. triangulus.2, 17, 19, 25, 46, 107 Mitobatinae $2,3,4,6$, $8,10,11,23,27,29,30,37,38$, $39,40,42,43,44,46,48,49,50$, $52,53,54,55,63,65,105,107$, 108

Mitobatoides 3

Mitobatula 3, 4, 15, 19, $23,26,27,32,33,41,44,46,48$, $49,50,53$

M. castanea ..19, 27, 32, 33, 44, 46 Mitoperna 3,4 Neoancistrotus. $4,17,21,25$, $28,30,32,33,34,36,37,38,41$, $42,46,49,50,53,55,61,80$

N. bipustulatus 33

N. gracilis. 27

N. guapimirim $18,30,33$ Neomitobates. $2,5,65,84$ Pachylus $16,17,18$, $20,21,23,36,37,39,40$
P. chilensis 16 $17,18,20,21,23,36,37,39,40$ Phalangodus. 2 Promitobates.. ......2, 4, 5, 7, 8, 9, 10, $16,17,18,19,20,22,23,24,25$, $26,27,28,29,30,31,32,33,34$, $35,36,37,38,39,41,42,44,45$, $46,48,49,50,53,56,60,62,63$, $65,67,70,73,77,80,84,88,92$, 95, 97, 100, 103, 105

P. bellus. $6,16,24,27$ $46,51,54,62,63,67,105$

P. decoratus 6,84

P. difficilis $5,28,38,44$, $45,51,63,64,65,70,73$ P.granulosissimus.... 6, 9, 103, 105 P. hatschbachi...................10, 28, $30,33,35,44,51,60,62,64,73$, 95, 105

P. hauseri. $6,88,105$

P. heteracanthus 5,84

P. hexacanthus. $5,7,9,65,103$

P. intermedius . $5,61,63$ $64,77,80,84,105$ P. nigripes...61, 63, 64, 77, 80, 84, 105

P. nitidus 6,80

P. ornatus . $.5,6,10,35$, $51,60,61,63,64,65,73,77,80$, 84, 95, 100, 105

P. spitzi. 5,84

$P$. viridigranulatus 10, 16, $29,30,33,34,45,51,60,62,63$, $88,97,105$ 
P. sp.n1_.........16, 17, 24, 25, 26,

$29,33,34,37,44,51,54,62,63$, 92, 95, 105

P. sp.n2 ..........16, 24, 32, 35, 37, $44,45,51,62,92,95,97$

P. sp.n3 …...........16, 27, 29, 30, $31,39,45,51,54,62,64,97,100$, 105

P. sp.n4.............26, 27, 30, 44, $46,51,60,62,64,100,103,105$

Promitobatoides................. 5, 65, 84 Roeweria............................... 3, 4 Ruschia. ...................4, 15, 18, 19, $26,28,29,35,41,44,45,49,50$, 53, 108 R. vellutina............. 15, 28, 29, 35 


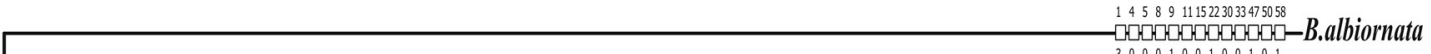

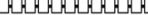

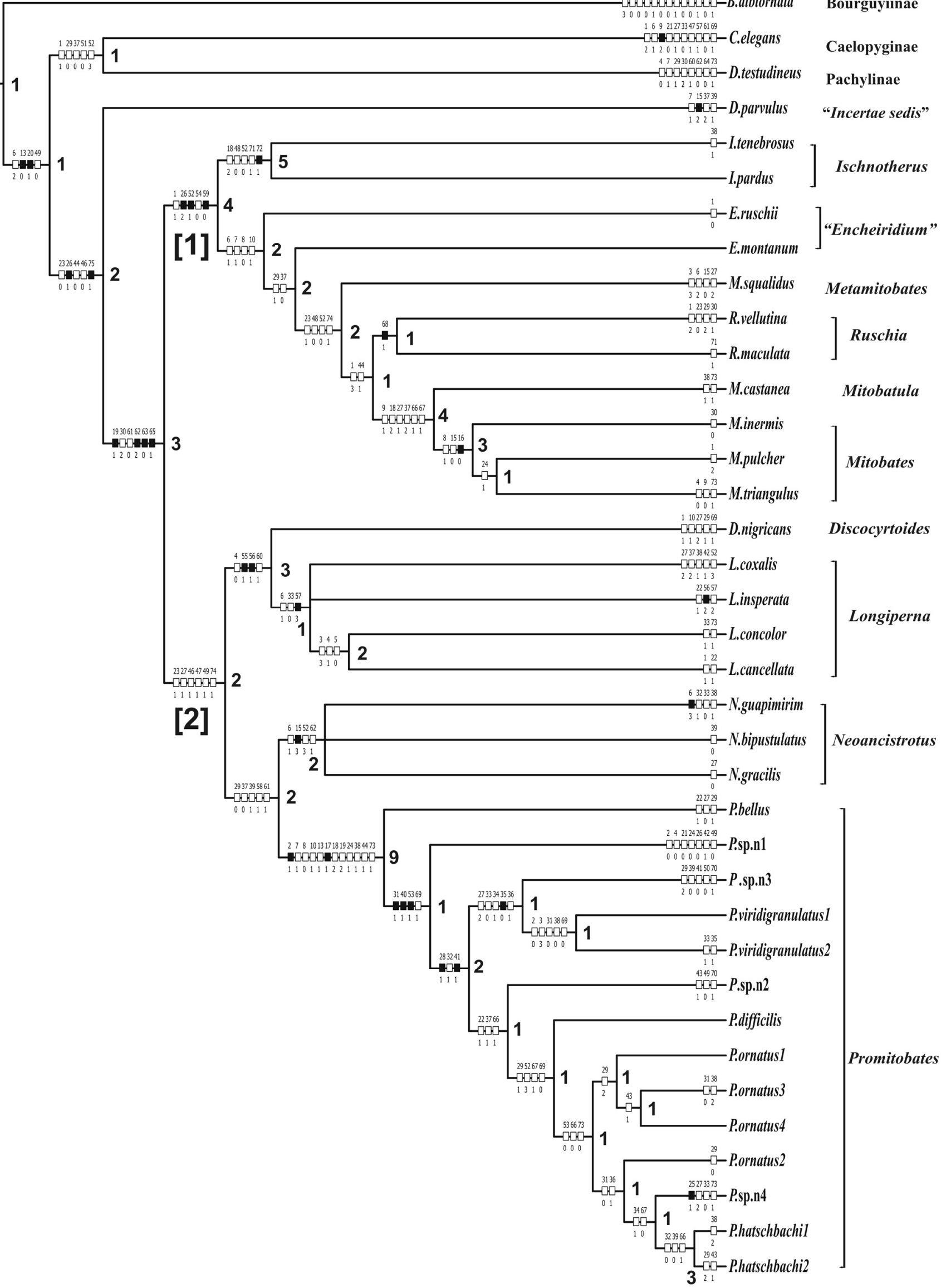

Figura 2. Hipótese de relacionamento entre os gêneros de Mitobatinae Simon, 1879. Árvore de consenso estrito ( $\mathrm{L}=258$; C.I $=0.38$; R.I $=0.72$ ) obtida a partir de duas árvores igualmente parcimoniosas $(\mathrm{L}=257$; C.I $=0.38 ;$ R.I $=0.72)$. Os quadrados negros representam sinapomorfias únicas; os brancos sinapomorfias homoplásticas. Os caracteres ambíguos foram otimizados por ACCTRAN. Os números em negrito e situados nos nós indicam os valores de suporte de Bremer; os números em negrito, maiores, [1] e [2] representam os dois principais clados de Mitobatinae. 


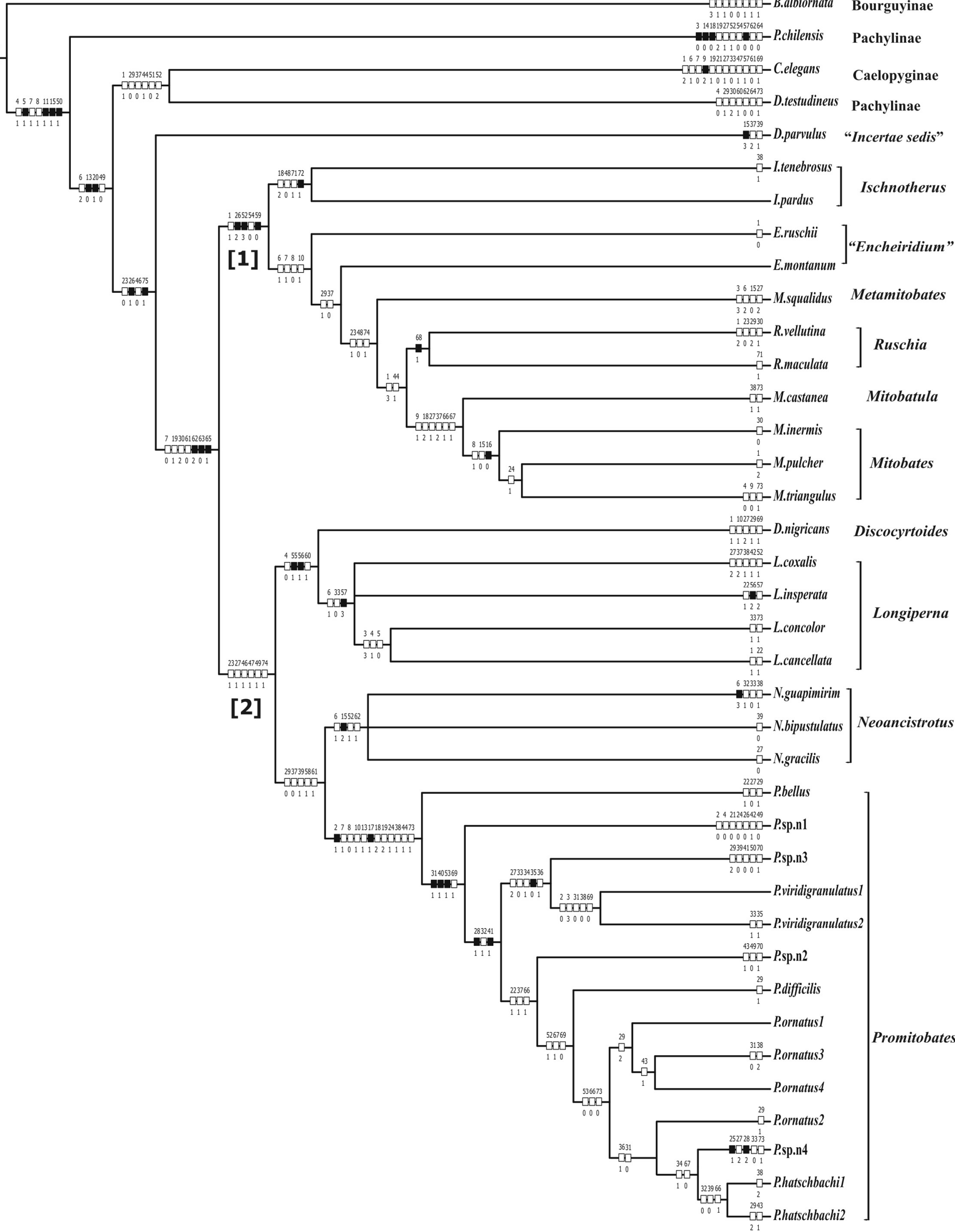

Figura 3. Hipótese de relacionamento entre os gêneros de Mitobatinae Simon, 1879, com o tratamento não aditivo dos dados. Árvore de consenso estrito ( $\mathrm{L}=255$; C.I=0.38; R.I=0.72) obtida a partir de duas árvores igualmente parcimoniosas ( $\mathrm{L}=254$; C.I=0.38; R.I=0.72). Os quadrados negros representam sinapomorfias únicas; os brancos sinapomorfias homoplásticas. Os caracteres ambíguos foram otimizados por ACCTRAN. 


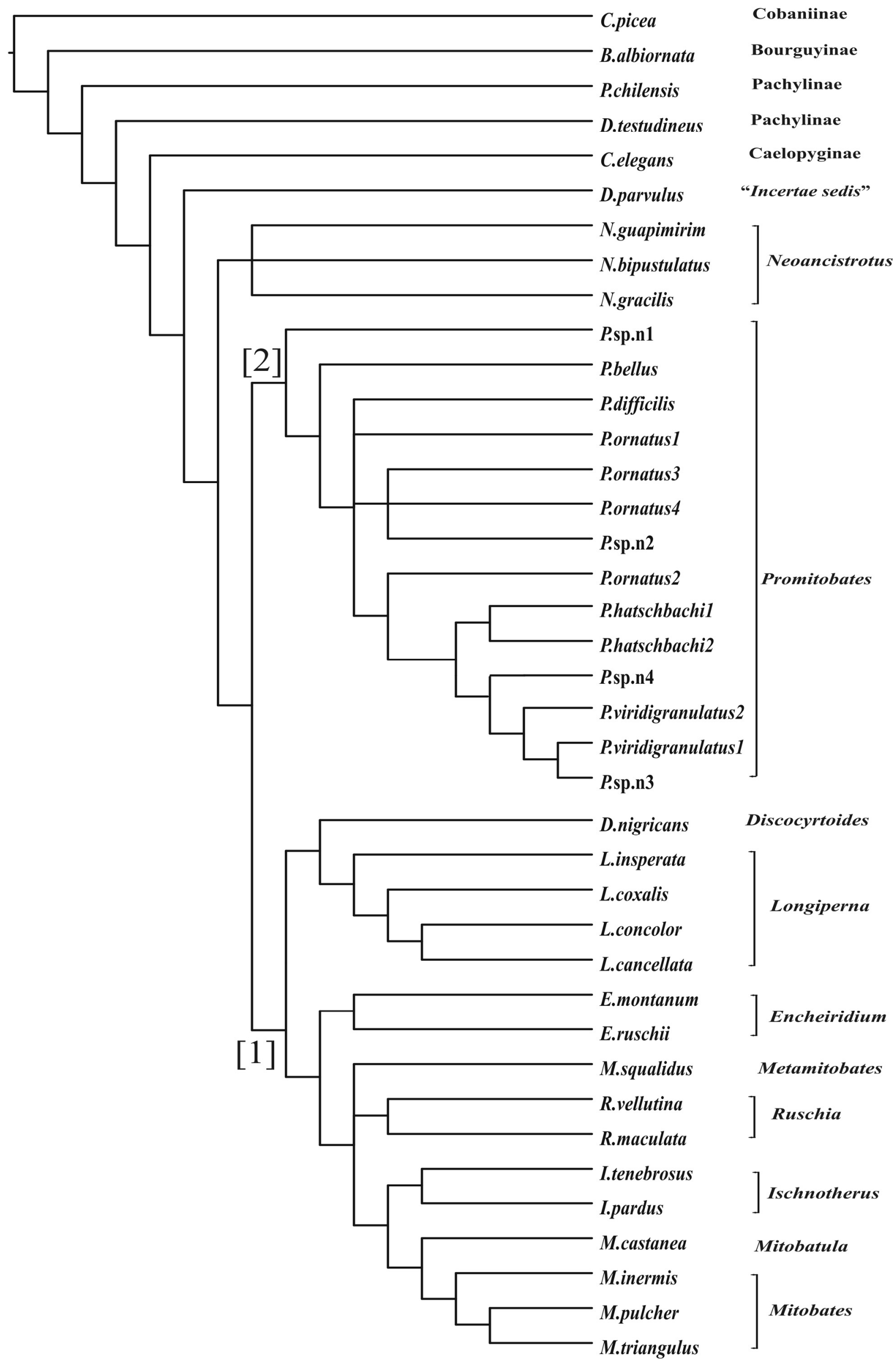

Figura 4. Hipótese de relacionamento entre os gêneros de Mitobatinae Simon, 1879. Árvore mais parcimoniosa obtida a partir da análise implementada com pesagem implícita $(\mathrm{K}=1$; Total fit $=34.25)$. 


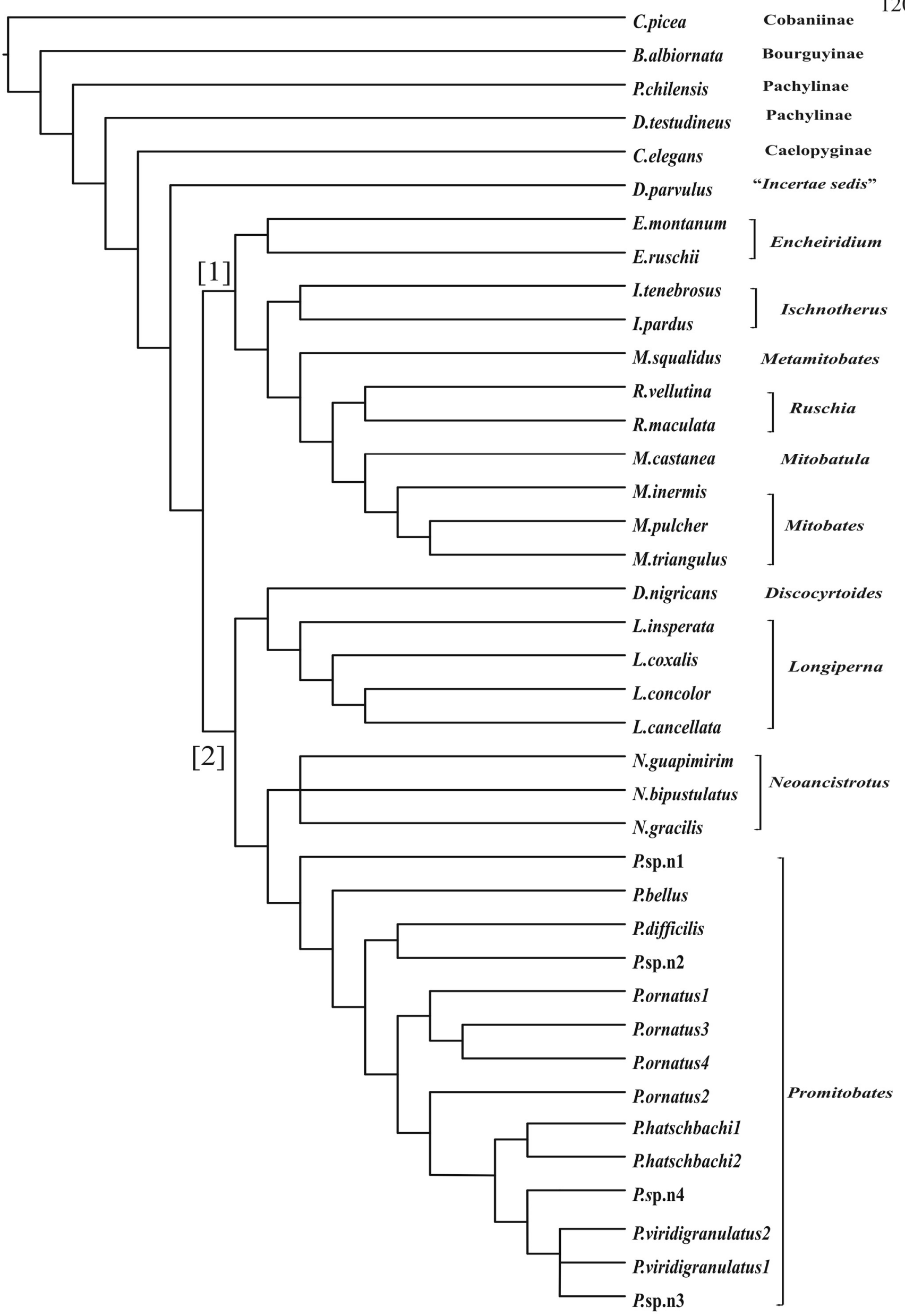

Figura 5. Hipótese de relacionamento entre os gêneros de Mitobatinae Simon, 1879. Árvore de consenso estrito obtida a partir da análise implementada com pesagem implícita $(\mathrm{K} 2$ a K5 $=1$; Total fit $=47.13)$. 


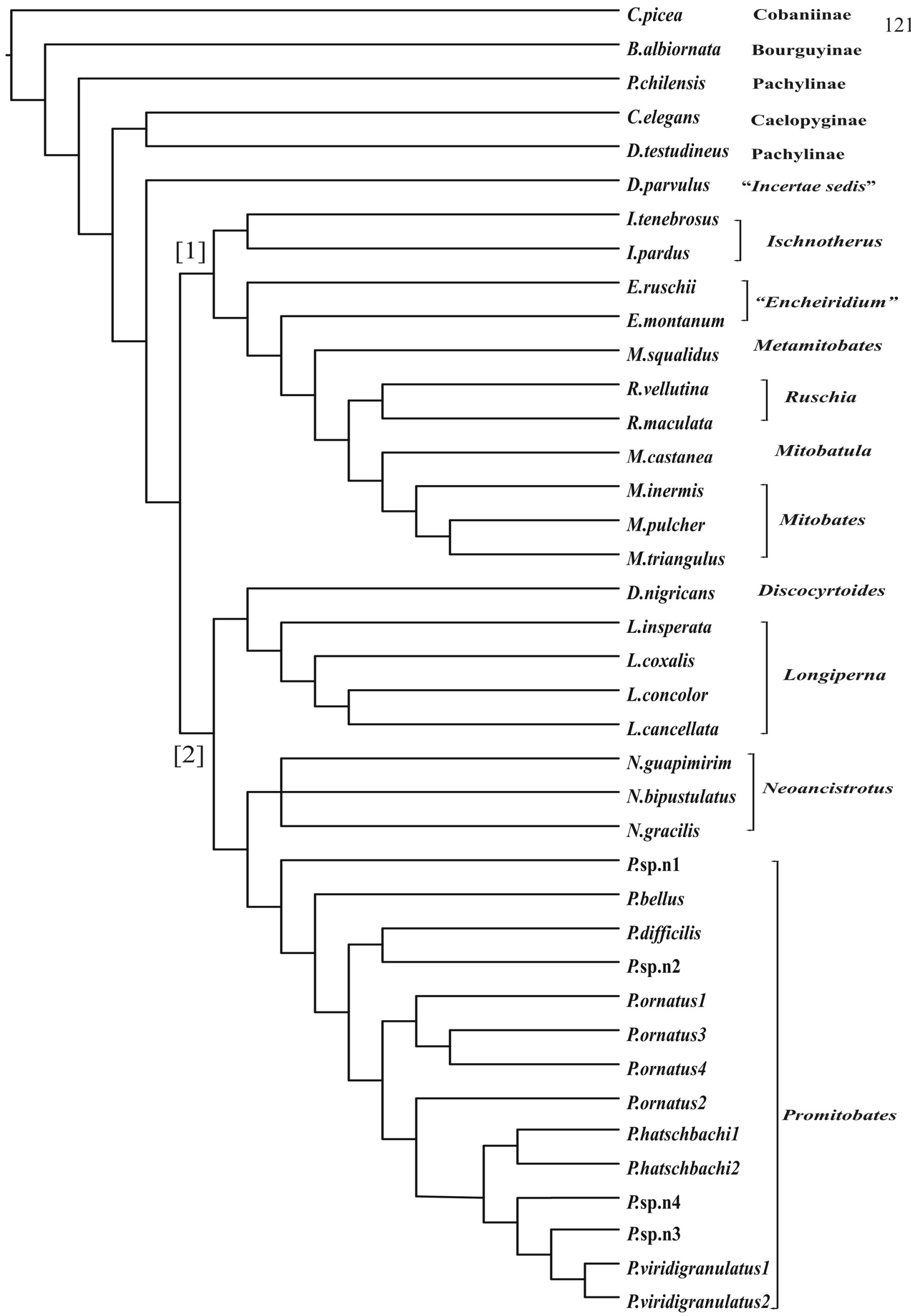

Figura 6. Hipótese de relacionamento entre os gêneros de Mitobatinae Simon, 1879. Árvore mais parcimoniosa obtida a partir da análise implementada com pesagem implícita $(\mathrm{K}=6$; Total Fit $=55.02)$ 


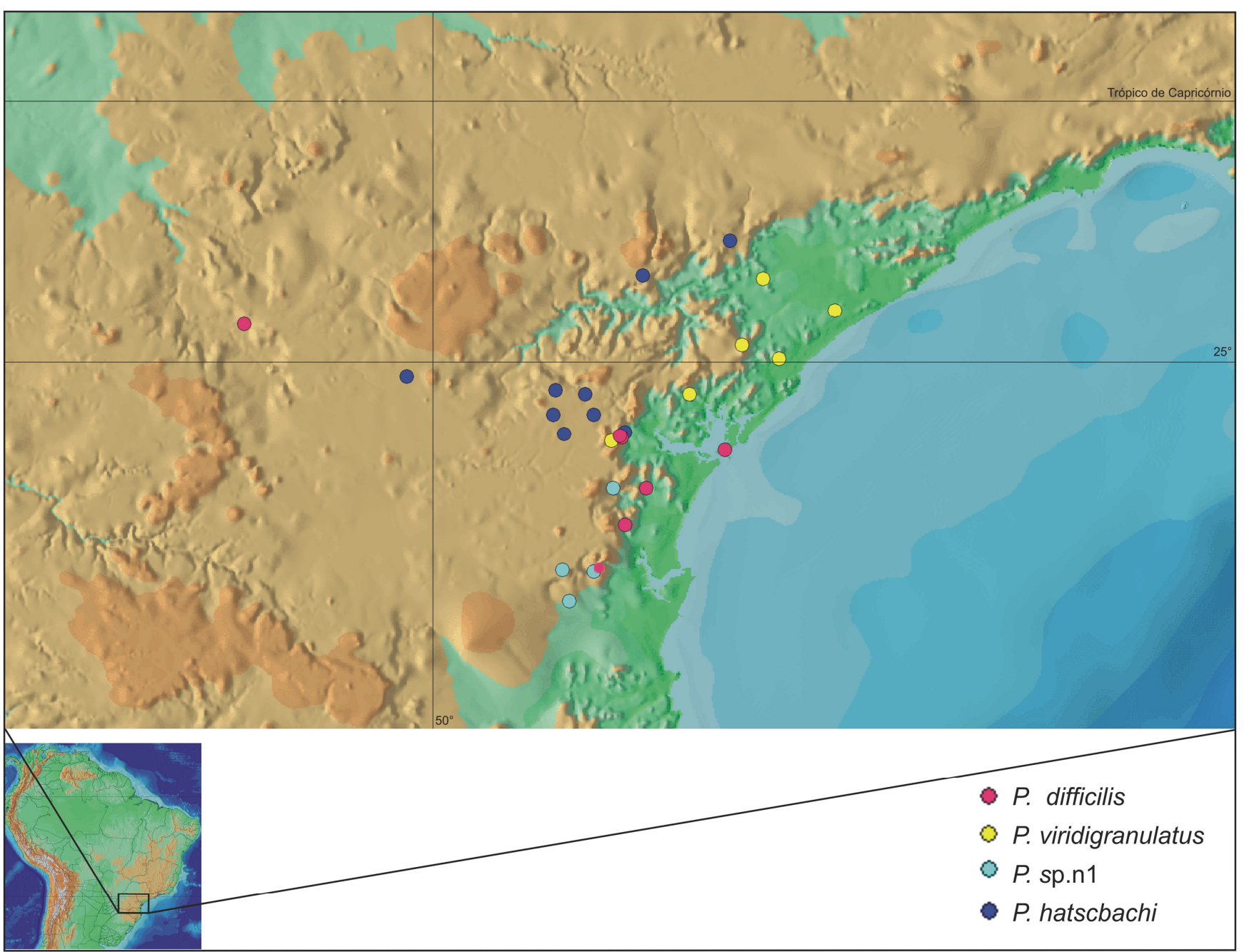

Figura 7A. Registros de distribuição das espécies de Promitobates de Santa Catarina, Paraná e sul de São Paulo. 


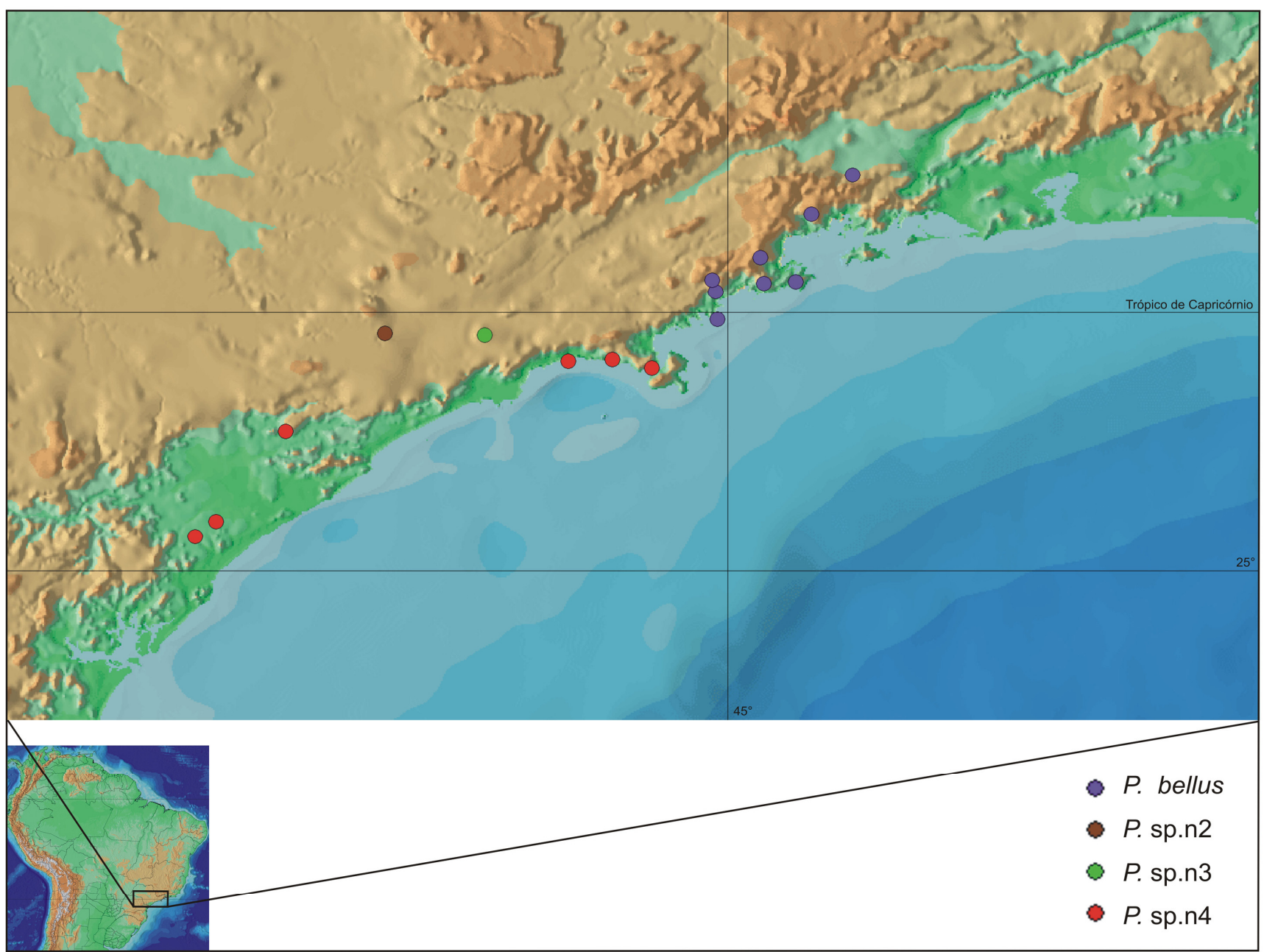

Figura 7B. Registros de distribuição das espécies de Promitobates de São Paulo e norte do Rio de Janeiro. 


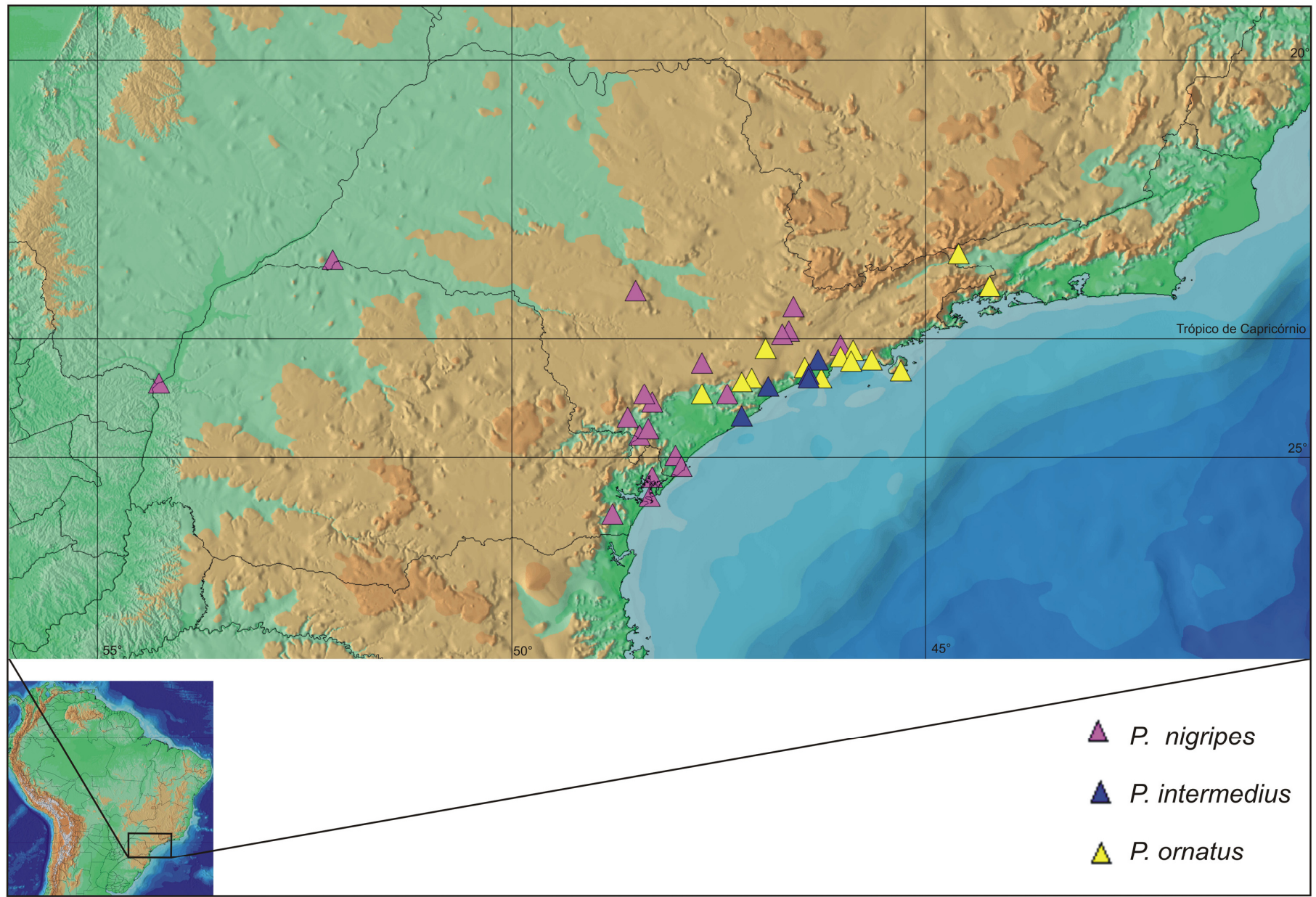

Figura 7C. Registros de distribuição das espécies do complexo P. ornatus. 

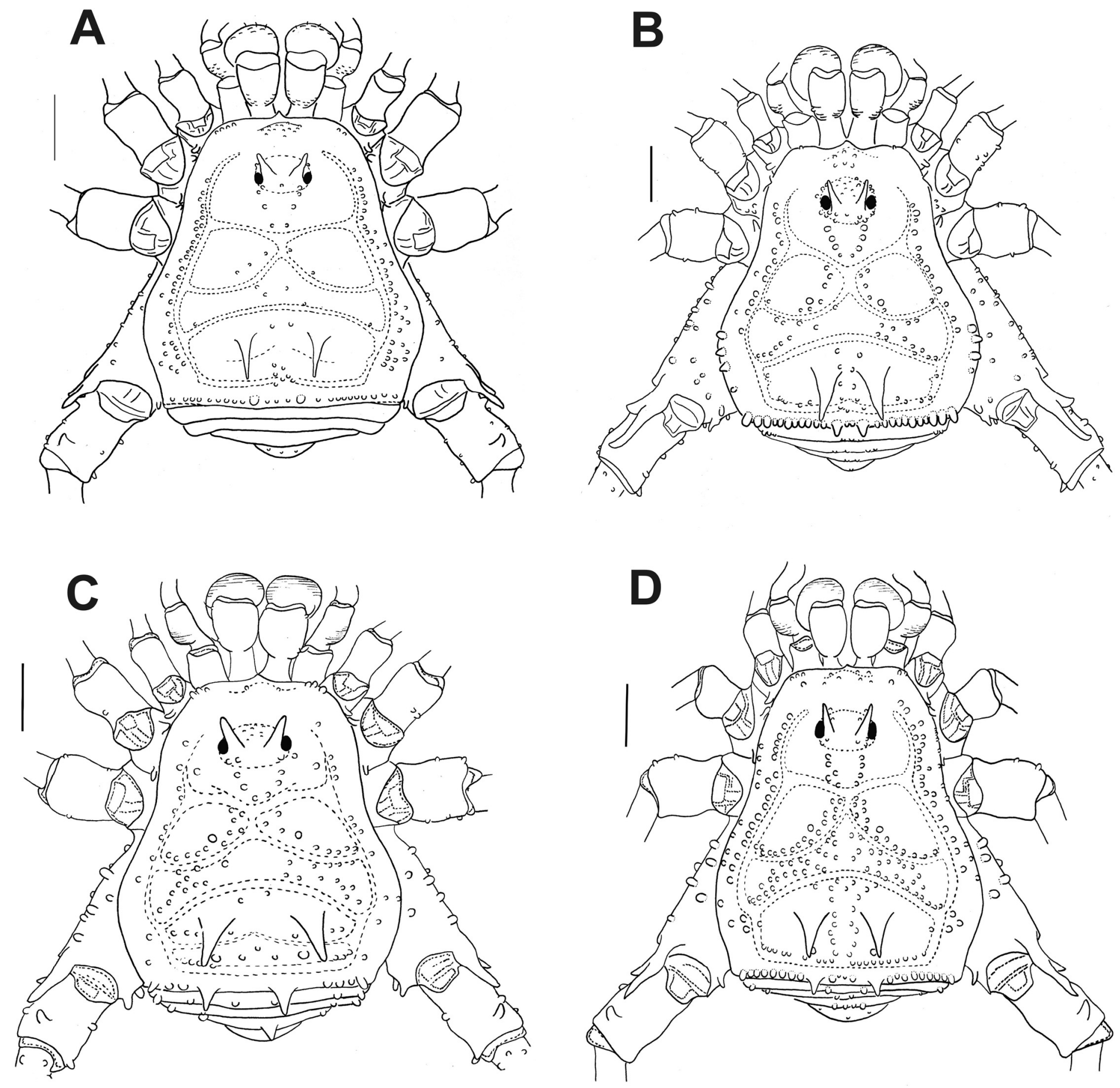

Figura 8. Hábito, vista dorsal de machos de Promitobates. A. P. bellus, (IBSP 3306); B. P. difficilis (MNRJ 11395, síntipo); C. P. hatschbachi (MHNCI 0164, holótipo; D. P. intermedius (MZSP 14410). Escala, $1 \mathrm{~mm}$. 

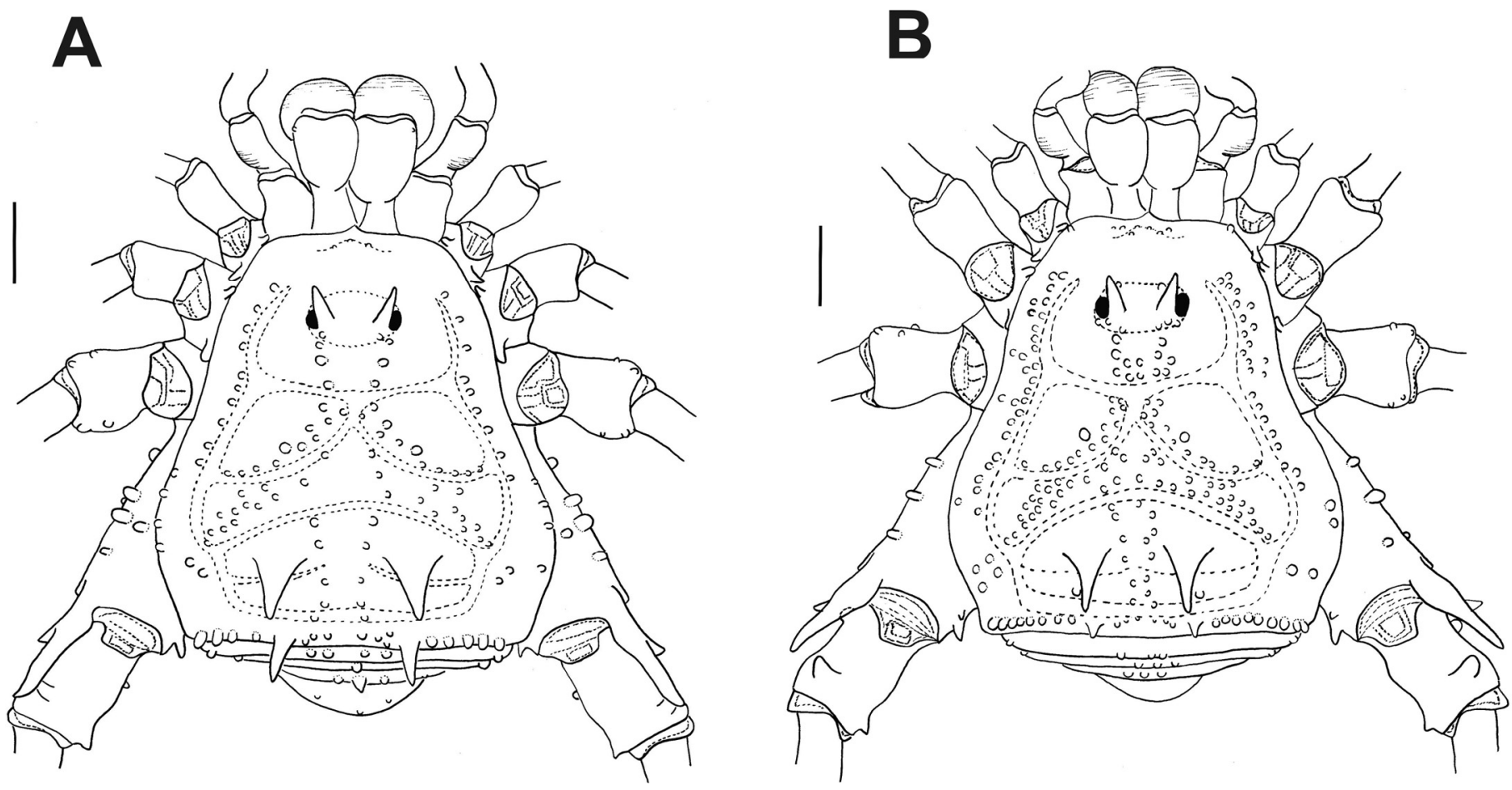

C

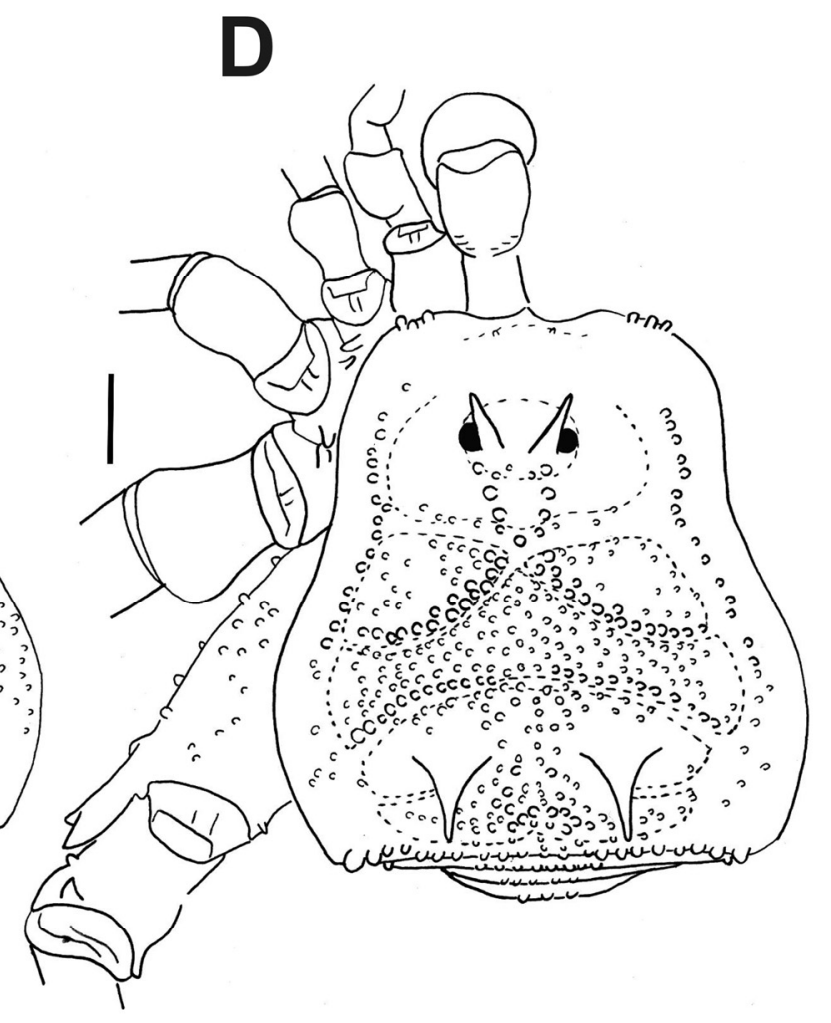

Figura 9. Hábito, vista dorsal de machos de Promitobates. A. P. nigripes, (MZSP 27425); B. P. ornatus (MZSP 27417); C e D. P. viridigranulatus (MZSP 27401),mostrando variação intraespecífica. Escala, $1 \mathrm{~mm}$. 

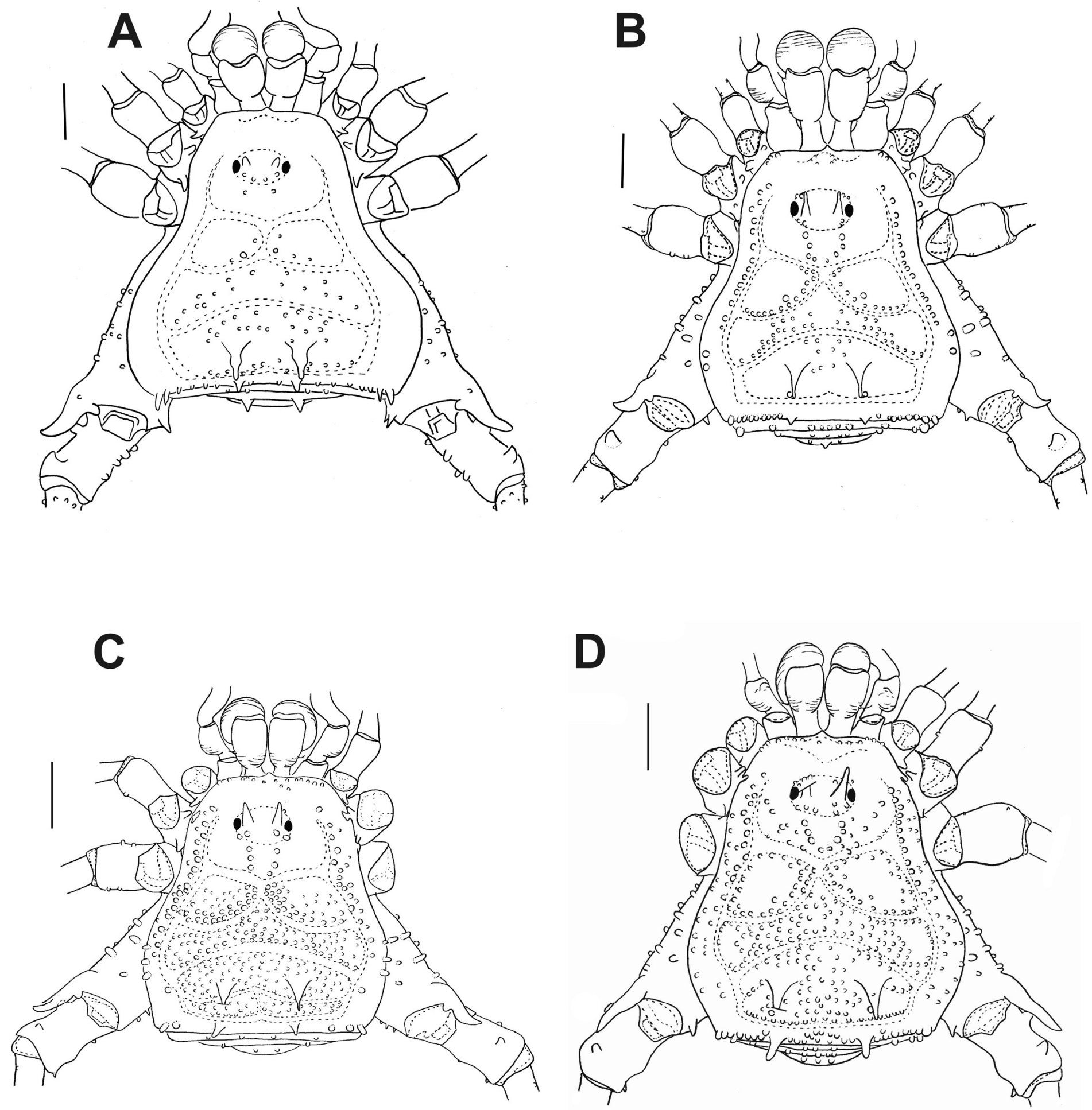

Figura 10. Hábito, vista dorsal de machos de Promitobates. A. P. sp.n1 (MZSP 27404); B. P. sp.n2 (MZSP 27406); C. P. sp.n3 (MZSP 16171); D. P. sp.n4 (MNRJ 4545).Escala, 1 mm. 

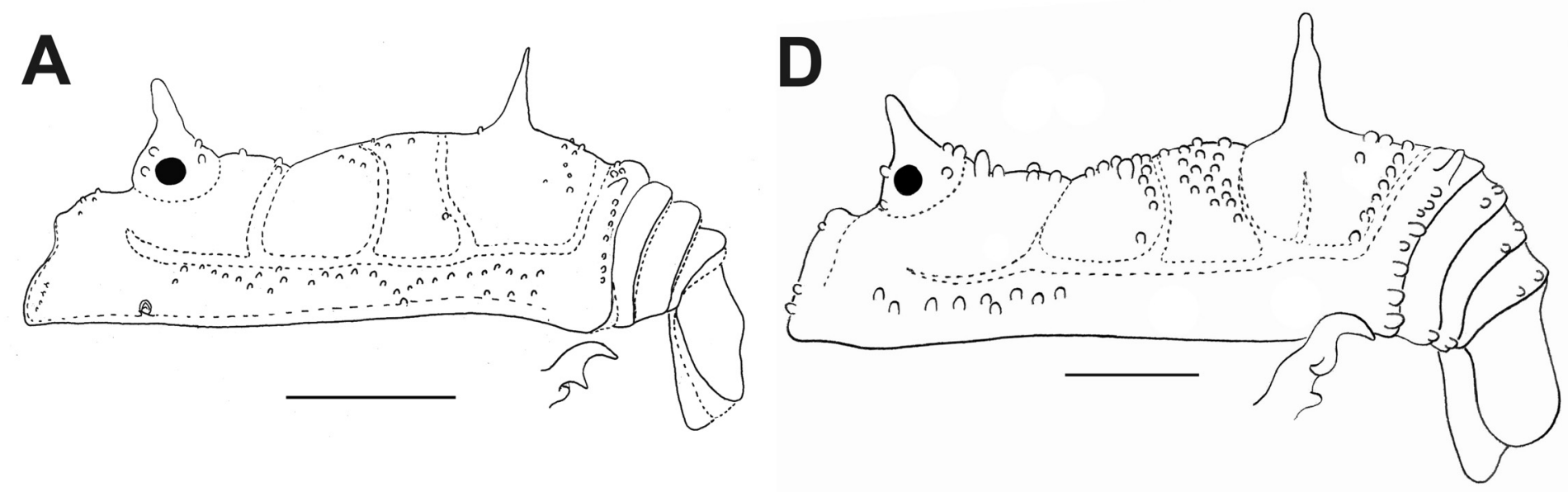

B
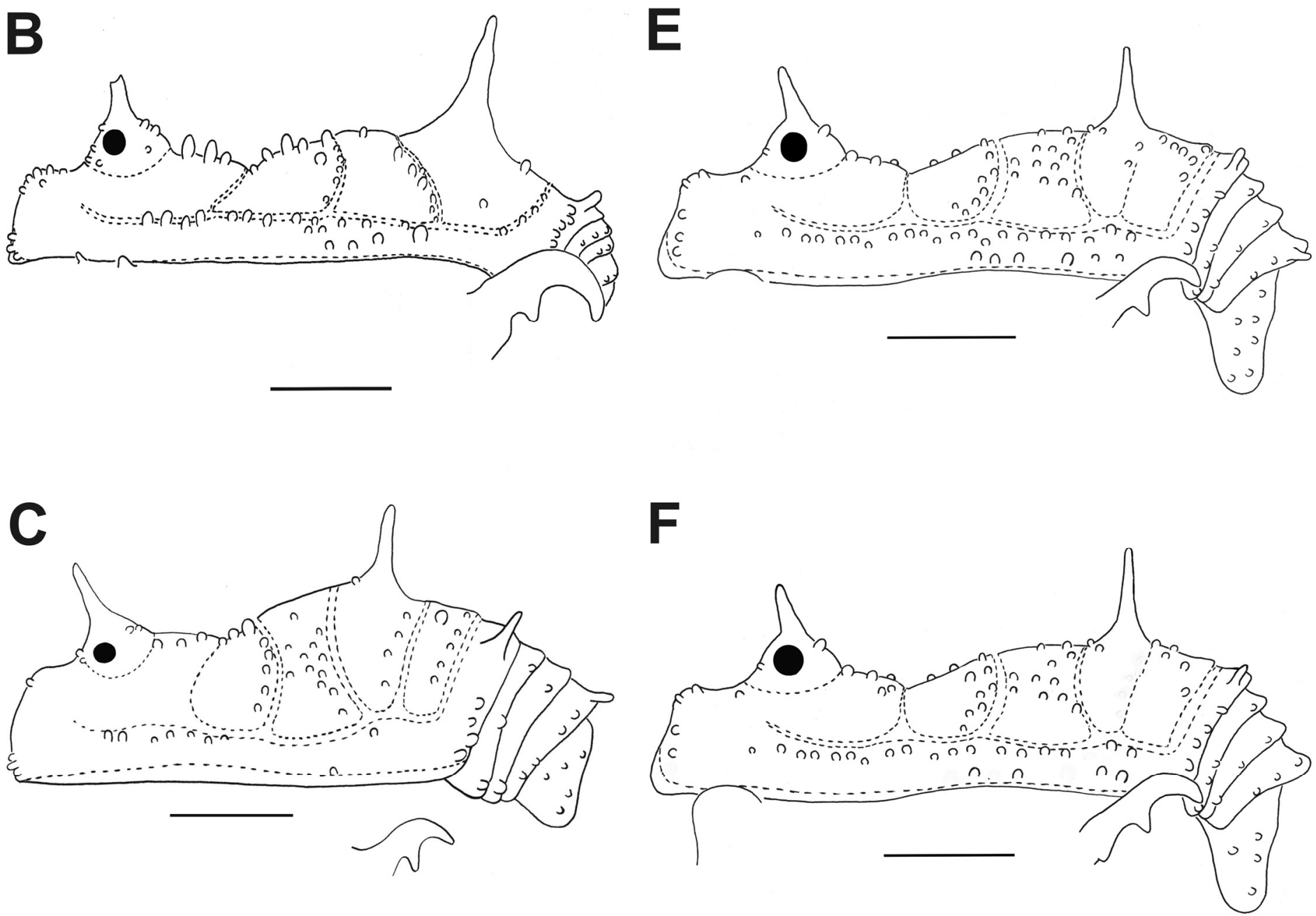

Figura 11. Hábito, vista lateral de machos de Promitobates. A. P. bellus (IBSP 3306); B. P . dificillis (MNRJ 11395, síntipo); C. P. hatschbachi (MHNCI 0164, holótipo); D. P. intermedius (MZSP 14410); E. P. nigripes (MZSP 27425); F. P. ornatus (MZSP 27417). Escala, $1 \mathrm{~mm}$. 

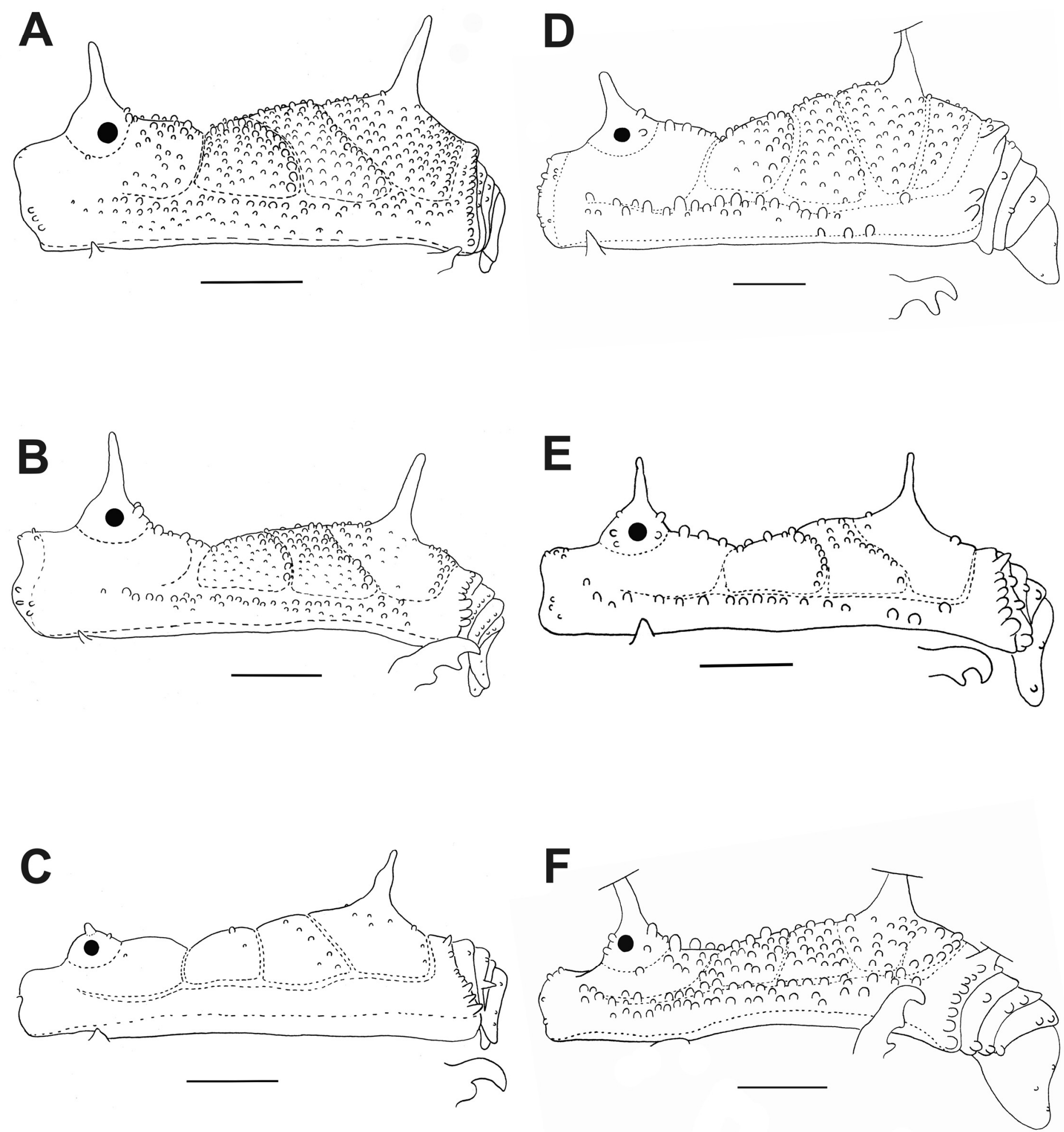

Figura 12. Hábito, vista lateral de machos de Promitobates. A e B. P. viridigranulatus, mostrando variação intraespecífica; A. MZSP 27401; B. MHNCI 6527; C. P. sp.n1 (MZSP 27404); D. P. sp.n2 (MZSP 27406); E. P. sp.n3 (MZSP 16171);F. P. sp.n4 (MNRJ 4545). Escala, 1 mm. 

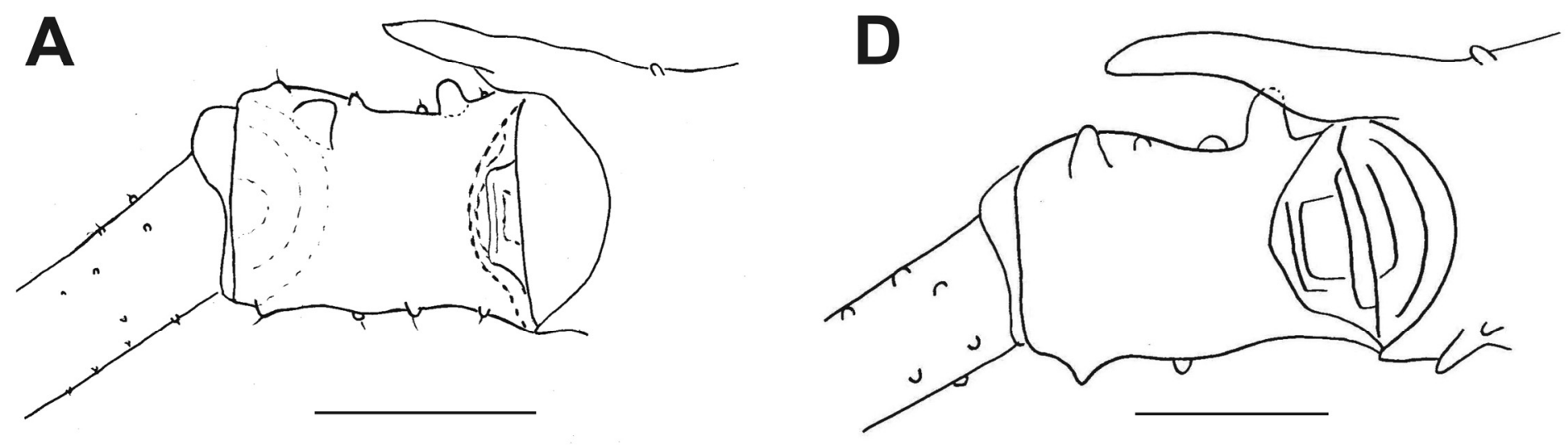

B
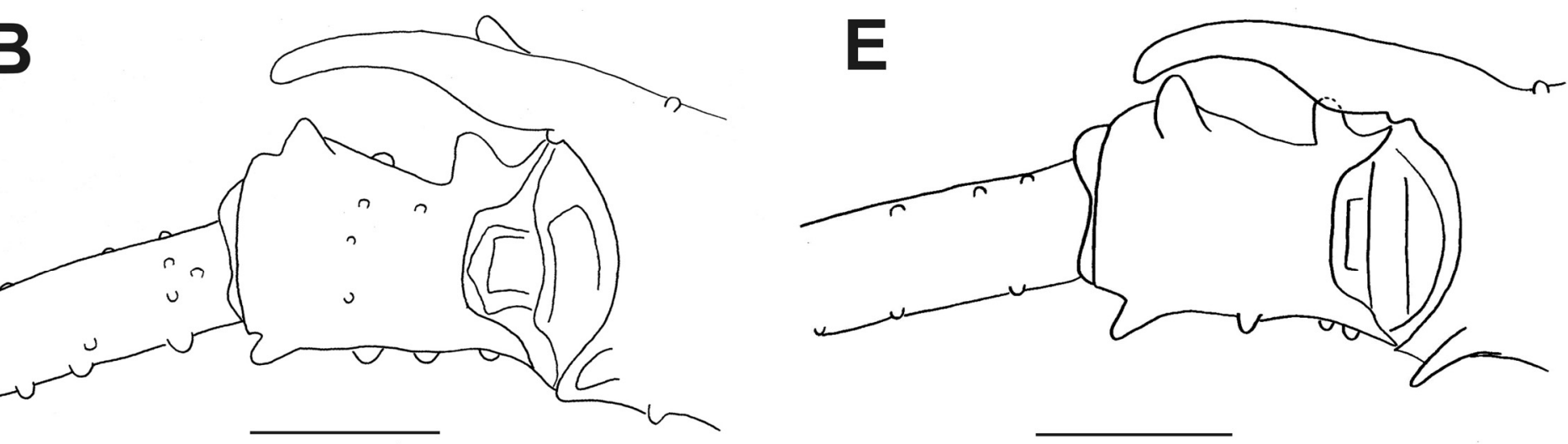

C
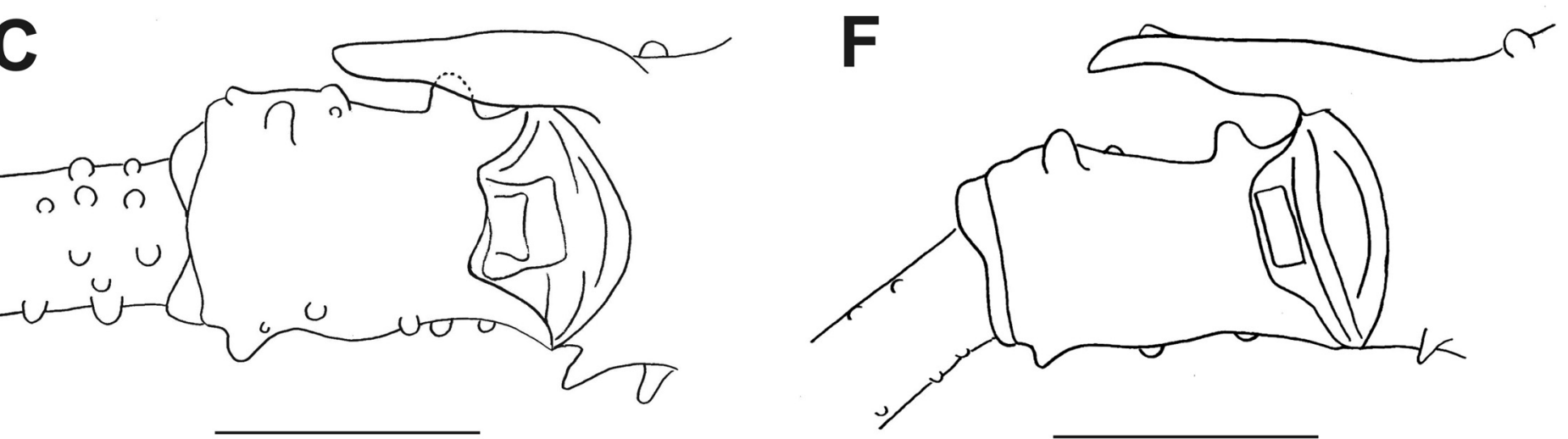

Figura 13. Machos de Promitobates; ápice da coxa, trocânter e base do fêmur, vista dorsal. IV. A. P. bellus (IBSP 3306);B. P . difficilis (MNRJ 11395, síntipo); C. P. hatschbachi (MHNCI 0164, holótipo); D. P. intermedius (MZSP 14410);E. P. nigripes (MZSP 27425); F. P. ornatus (MZSP 27417). Escala, $1 \mathrm{~mm}$. 

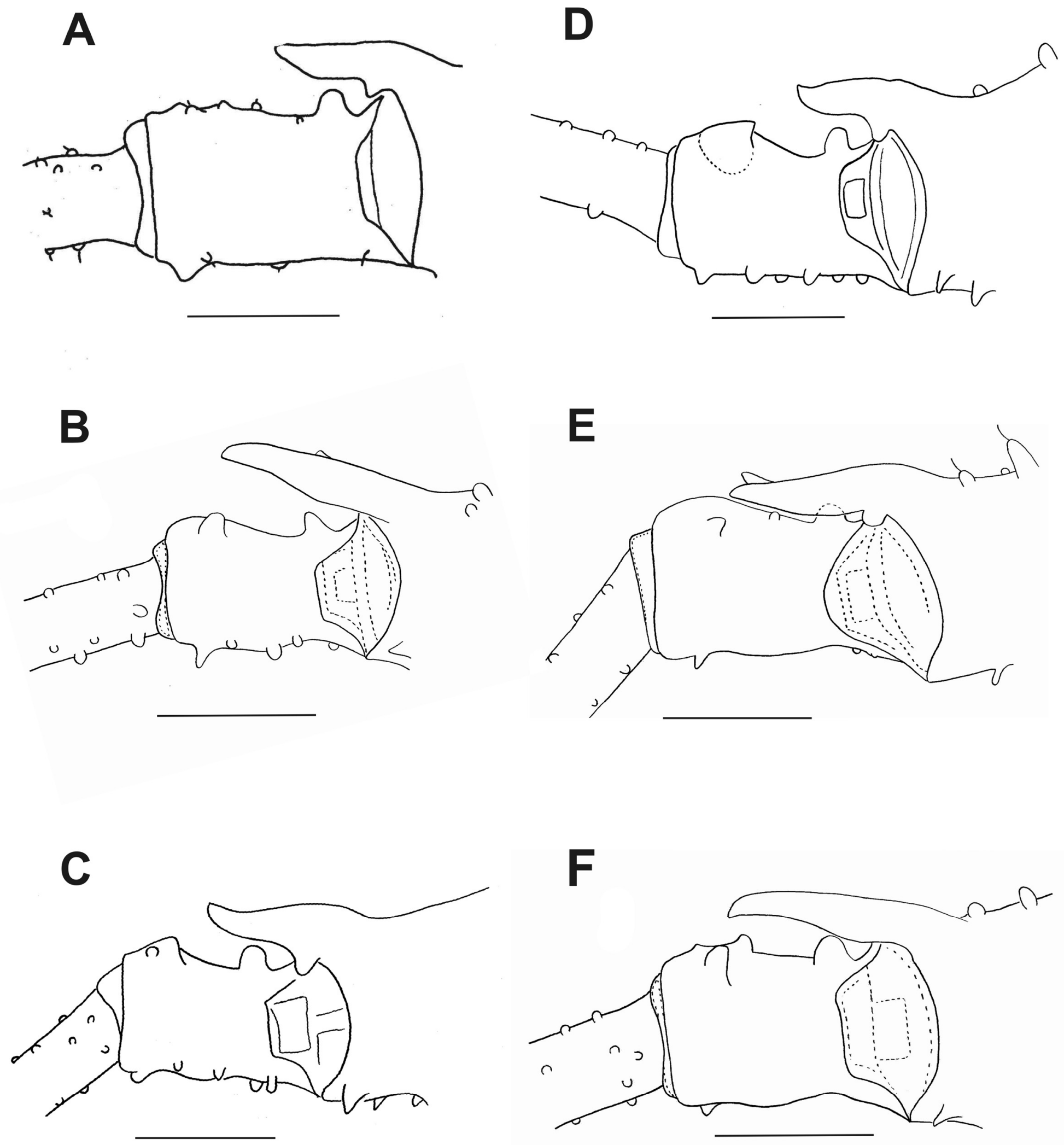

Figura 14. Machos de Promitobates, ápice da coxa, trocânter e base do fềmur IV, vista dorsal. A e B. P. viridigranulatus, A. MZSP 27401; B. MHNCI 6527; C. P. sp.n1 (MZSP 27404); D. P. sp.n2 (MZSP 27406); E. P. sp.n3 (MZSP 16171); F. P. sp.n4 (MNRJ 04545); Escala, 1 mm. 

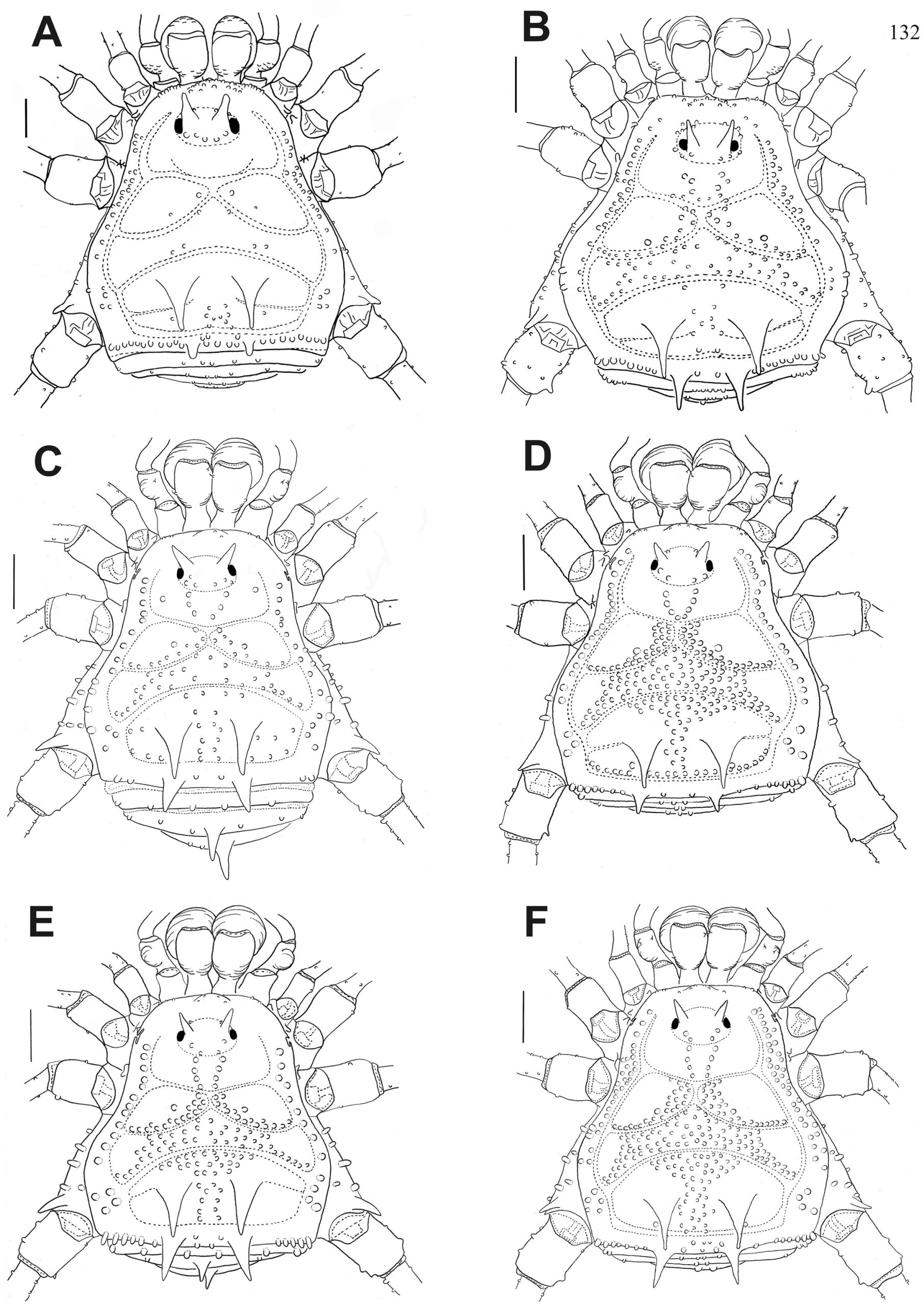

Figura 15. Hábito, vista dorsal das fêmeas de Promitobates. A. P. bellus (MZSP-19509); B. P. dificillis (MNRJ-11395, síntipo); C. Promitobates hatschbachi (MZSP 18811); D. P. intermedius (MZSP-16764); E. P. nigripes (MZSP -31029); F. P. ornatus (MZSP 27440). Escala $=1 \mathrm{~mm}$. 

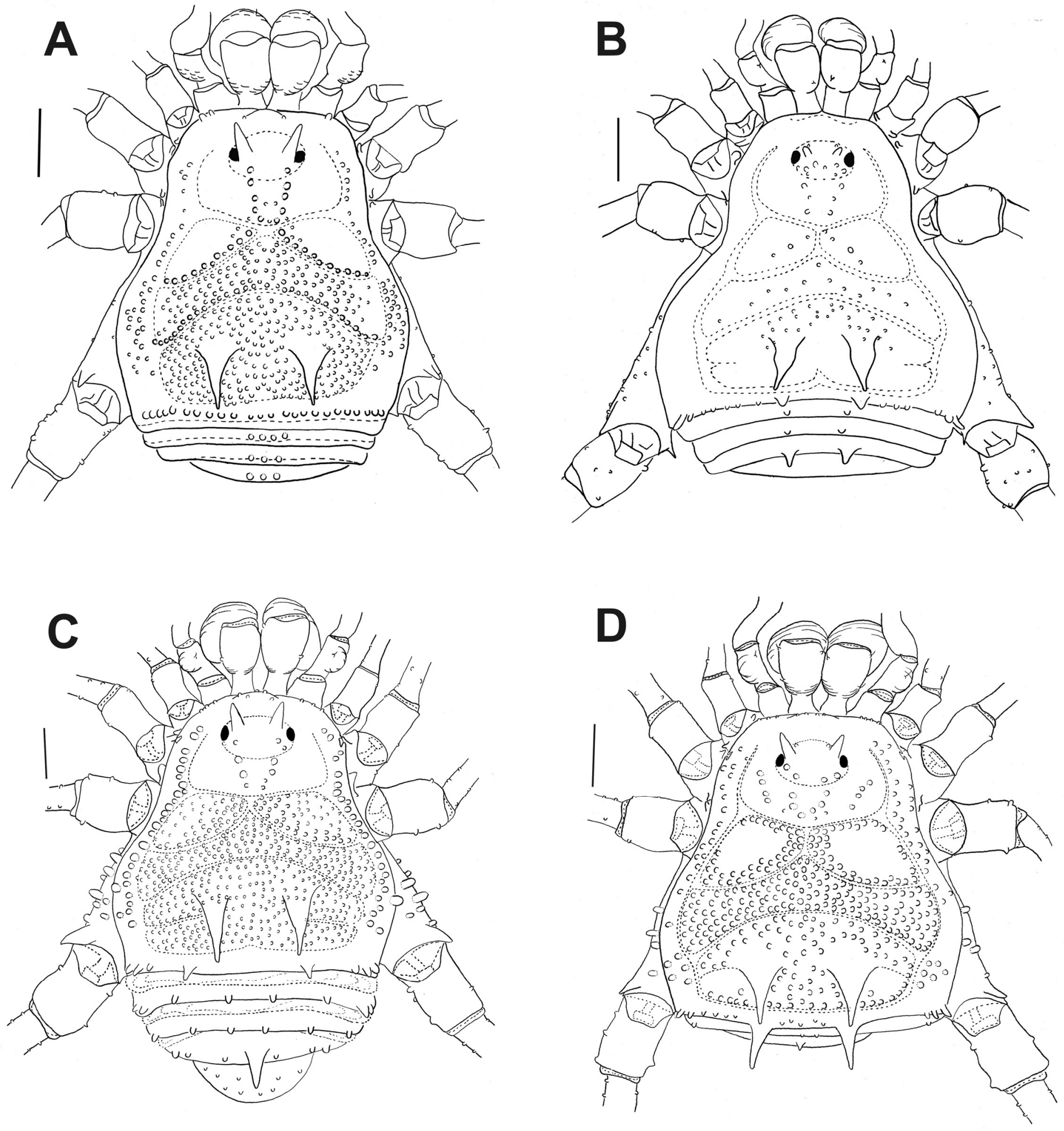

Figura 16. Hábito, vista dorsal de fêmeas de Promitobates. A. P. viridigranulatus (MZSP 18128); B. P. sp.n1 (MZSP 18635); C. P. sp.n3 (MZSP 17161, parátipo); D. P. sp.n4 (MZSP 17249). Escala, 1 mm. 

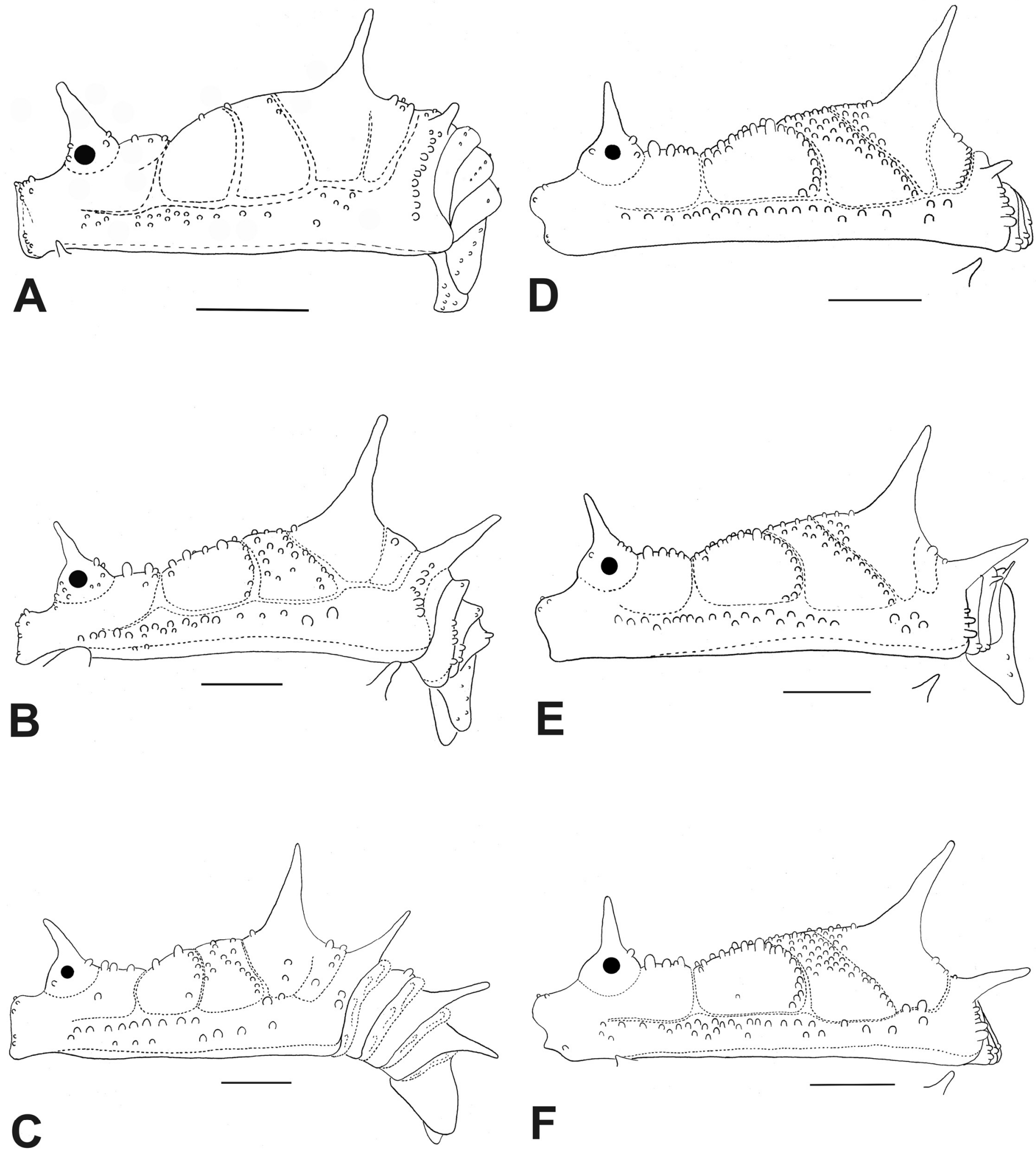

Figura 17. Hábito, vista lateral de fêmeas de Promitobates. A. P. bellus (MZSP 19509); B. P. difficilis (MNRJ 11395, síntipo); C. P. hatschbachi (MZSP 18811); D. P. intermedius (MZSP 16764); E. P. nigripes (MZSP 31029); F. P. ornatus (MZSP 27440). Escala, 1 mm. 

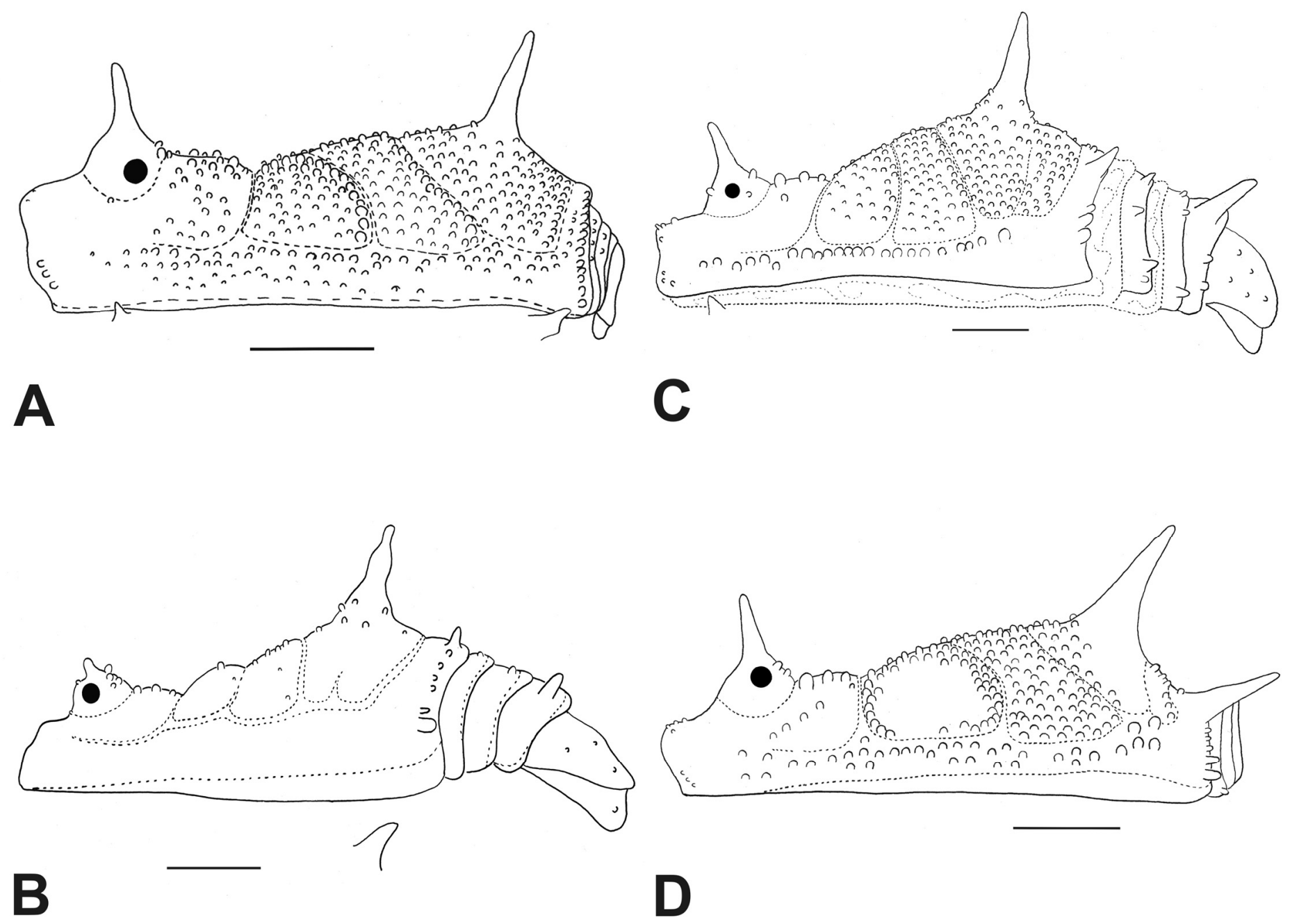

Figura 18. Hábito, vista lateral de fêmeas de Promitobates. A. P. viridigranulatus, (MZSP 18128); B. P. sp.n1 (MZSP 18635); C. P. sp.n3 (MZSP 17161); D. P. sp.n4 (MZSP 17249.Escala, 1 mm. 

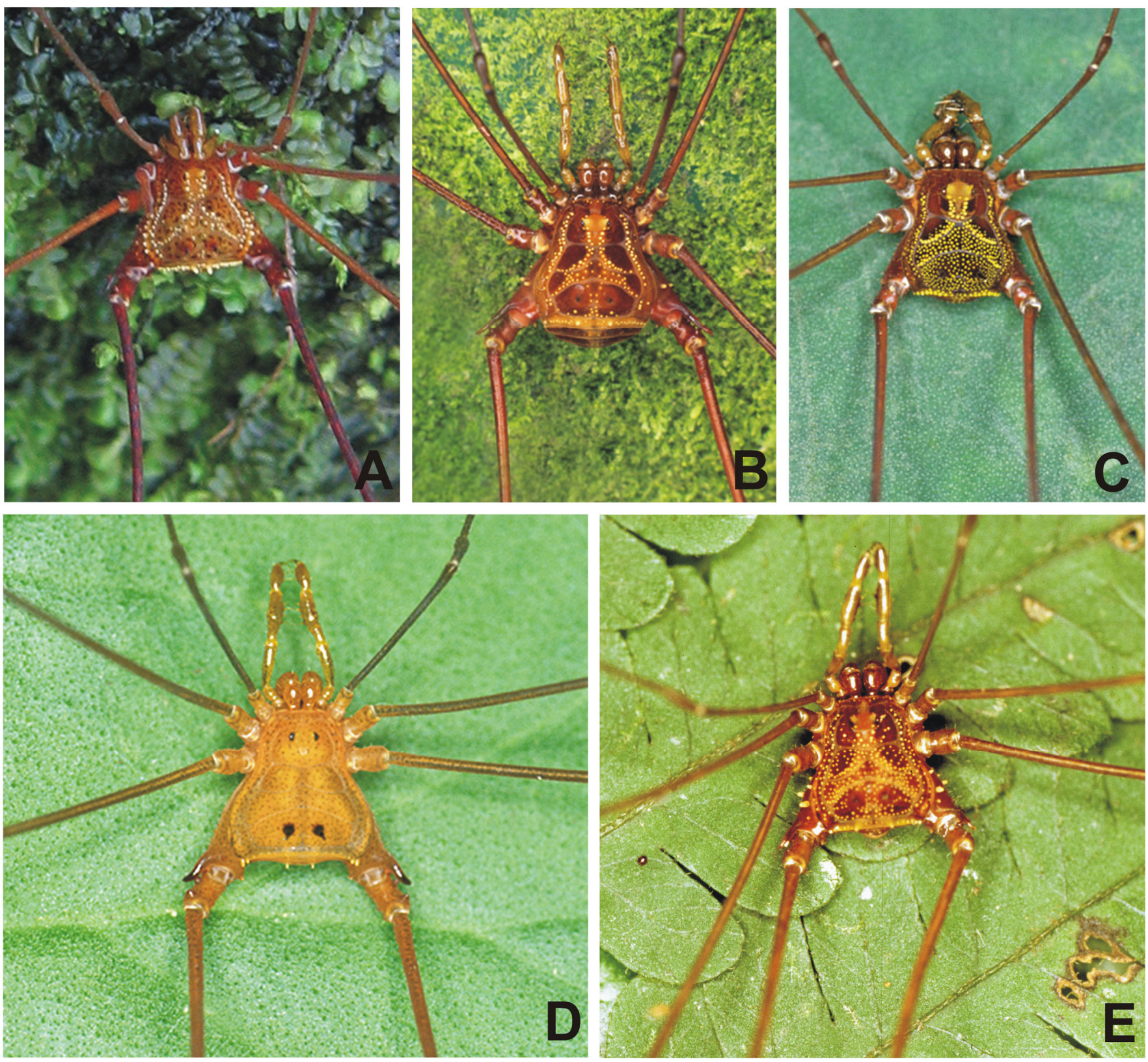

Figura 19. Fotografias de machos de Promitobates em vista dorsal; material vivo. A. P. difficilis (SC - Joinville); B. P. ornatus (SP - Paranapiacaba); C. P. viridigranulatus (PR - Guaratuba); D. $P$. sp.n1 (SC - São Bento do Sul) ; E. P. sp.n4 (SP - Miracatu). 

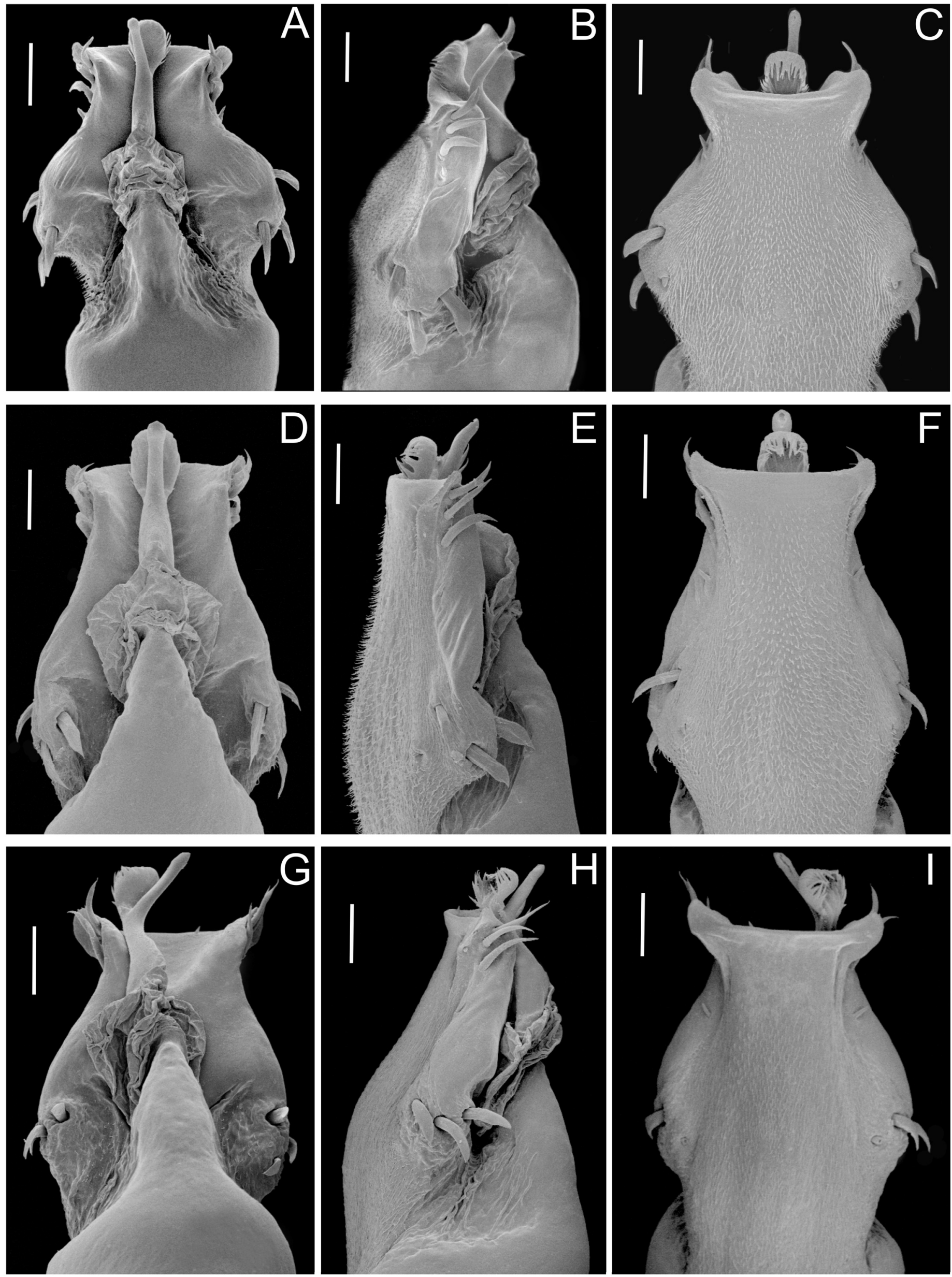

Figura 20. Pênis de Promitobates. A, B e C. P. bellus (IBSP-1736); A. vista dorsal; B. vista lateral; C. vista ventral. D, E e F. P. difficilis (MHNCI-6130); A. vista dorsal; B. vista lateral; C. vista ventral. G, H e I. P. hatschbachi (MZSP-943); A. vista dorsal; B. vista lateral; C. vista ventral. Escala $=0,05 \mathrm{~mm}$. 

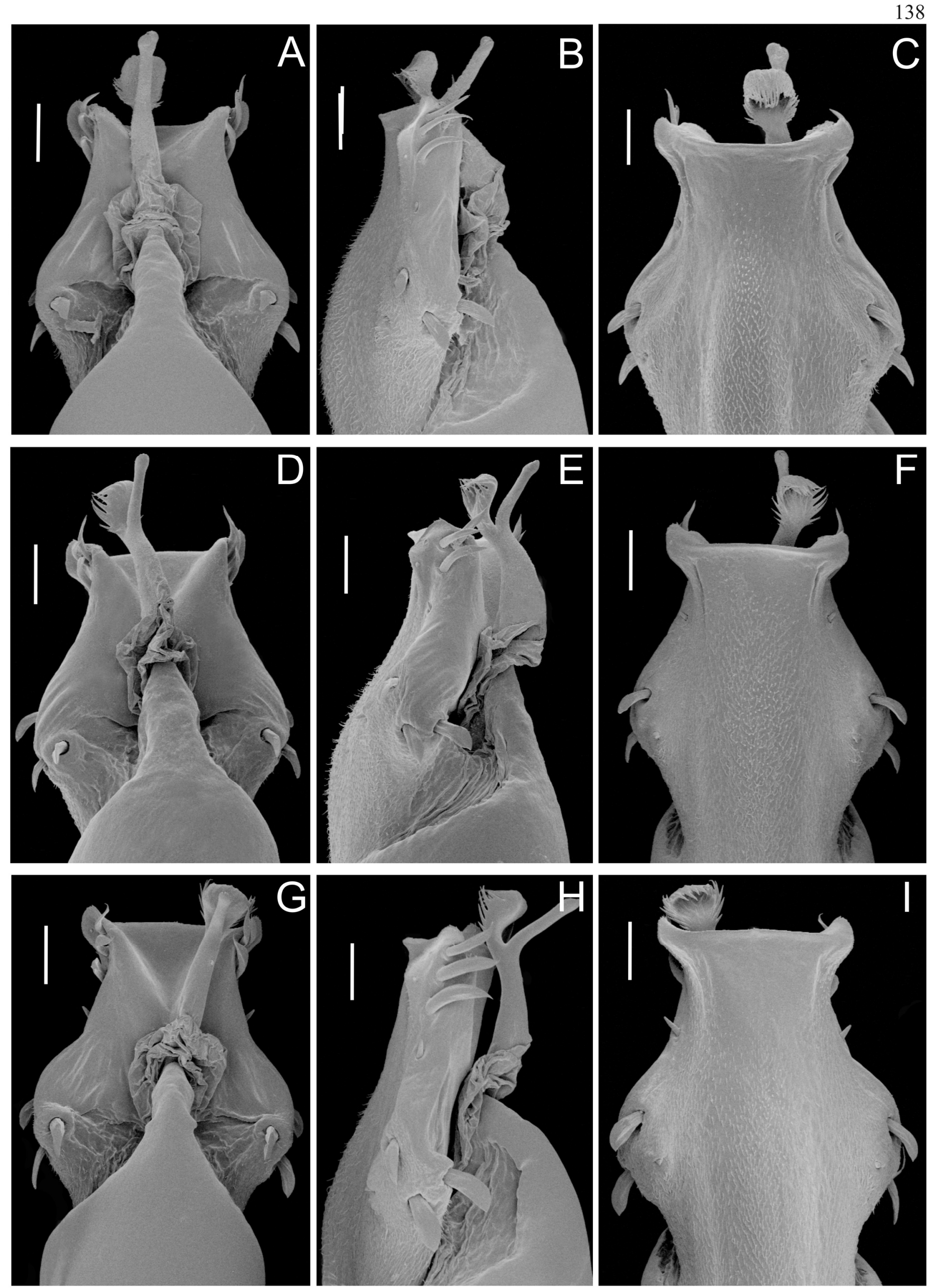

Figura 21. Pênis de Promitobates. A, B e C. P. intermedius (MZSP-27419); A. vista dorsal; B. vista lateral; C. vista ventral. D, E e F. P. nigripes (MZSP-27425); A. vista dorsal; B. vista lateral; C. vista ventral. G, H e I. P. ornatus (MZSP-14401); A. vista dorsal; B. vista lateral; C. vista ventral. Escala $=0,05 \mathrm{~mm}$. 

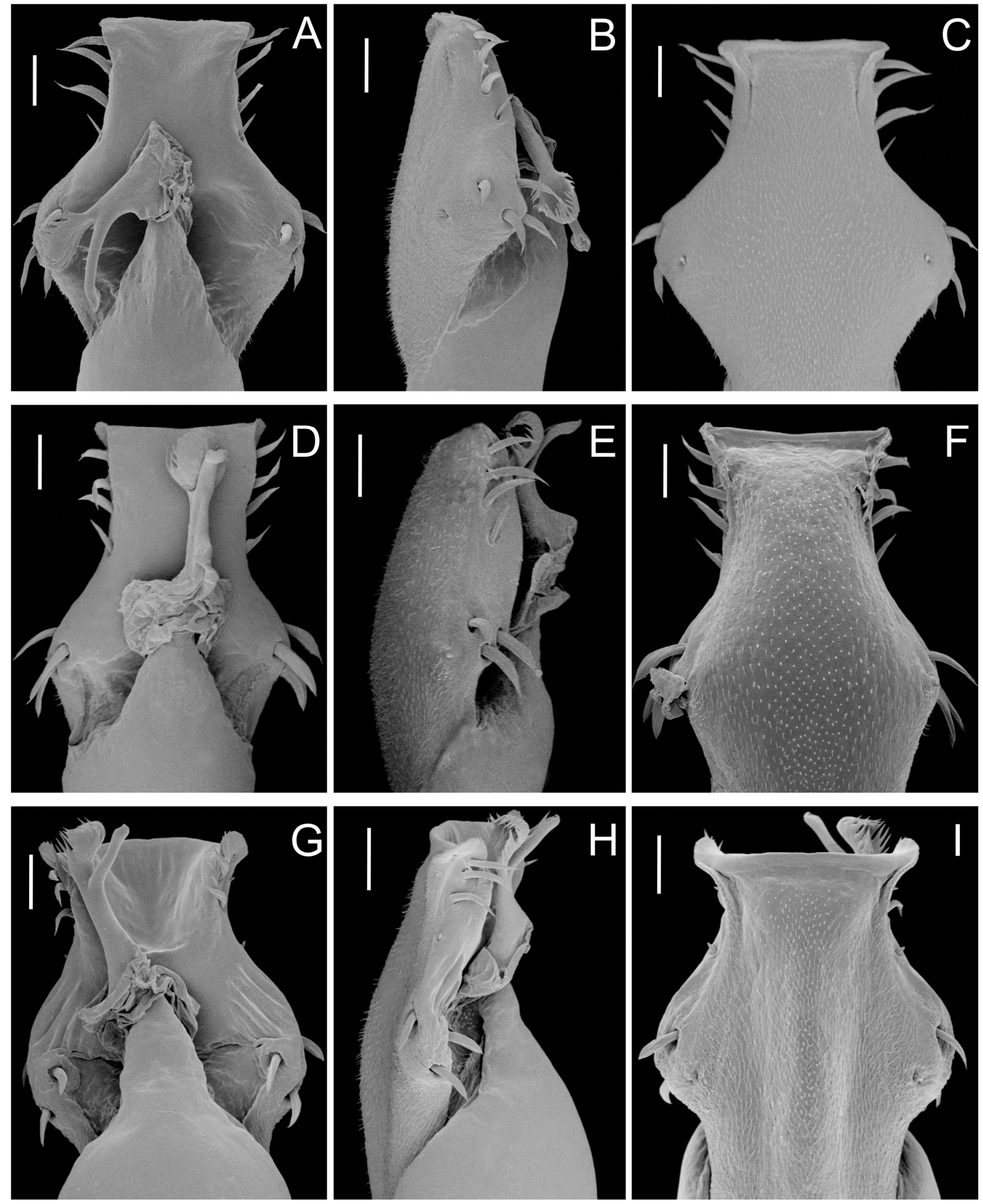

Figura 22. Pênis de Promitobates. A, B e C. P. viridigranulatus (MZSP-27401); A. vista dorsal; B. vista lateral; C. vista ventral. D, E e F. P. sp.n1 (MZSP-18649); A. vista dorsal; B. vista lateral; C. vista ventral. G, H e I. $P$. sp.n2 (MZSP-27406); A. vista dorsal; B. vista lateral; C. vista ventral. Escala $=0,05 \mathrm{~mm}$. 

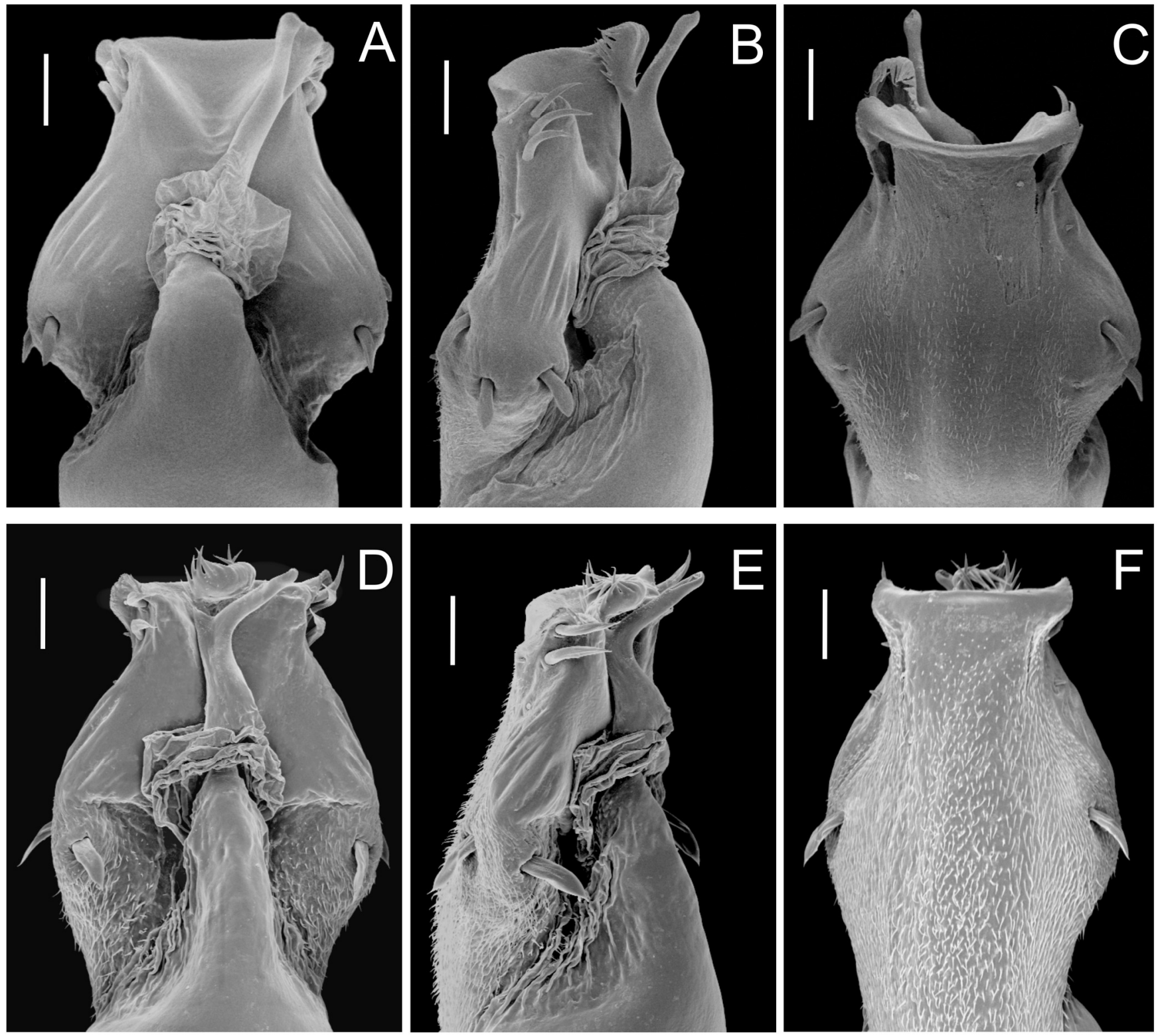

Figura 23. Pênis de Promitobates. A, B e C. P. sp.n3 (MZSP-17161); A. vista dorsal; B. vista lateral; C. vista ventral. D, E e F. P. sp.n4 (MZSP-17047); A. vista dorsal; B. vista lateral; C. vista ventral. Escala $=0,05 \mathrm{~mm}$. 
Tabela 02. Matriz de 75 caracteres utilizados na análise cladística de Mitobatinae (Opiliones, Gonyleptidae), separada por região do corpo.

\begin{tabular}{|c|c|c|c|c|c|c|c|c|c|c|c|c|c|c|c|c|c|c|c|c|c|c|c|c|c|c|c|c|c|c|c|c|c|c|c|c|c|c|c|c|}
\hline \multirow{3}{*}{ TAXA } & \multicolumn{19}{|c|}{ GENITÁLIA } & \multicolumn{21}{|c|}{ ESCUDO DORSAL } \\
\hline & \multicolumn{7}{|c|}{ placa ventral } & \multicolumn{3}{|c|}{ estilo } & \multicolumn{8}{|c|}{ processo ventral } & & \multicolumn{6}{|c|}{ rossoma } & \multicolumn{15}{|c|}{ áreas I - IV } \\
\hline & 1 & 2 & 3 & 4 & 5 & 6 & 7 & 8 & 9 & 10 & 11 & 12 & 13 & 14 & 15 & 16 & 17 & 18 & 19 & 20 & 21 & 22 & 23 & 24 & 25 & 26 & 27 & 28 & 29 & 30 & 31 & 32 & 33 & 34 & 35 & 36 & 37 & 383 & 39 & 40 \\
\hline C.picea & 2 & 0 & 1 & 0 & 0 & 0 & 0 & 0 & 0 & 0 & 0 & 0 & 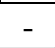 & - & - & - & - & - & 0 & 0 & -1 & $?$ & 1 & 0 & 0 & 0 & 1 & 0 & 2 & 1 & - & - & 1 & 0 & 1 & 0 & 1 & 0 & 0 & - \\
\hline B.albiornata & 3 & 0 & 2 & 0 & 0 & 0 & 0 & 0 & 1 & 0 & 0 & 1 & 1 & 1 & 0 & 1 & 0 & 1 & 0 & 0 & 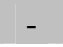 & 1 & 1 & 0 & 0 & 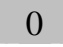 & 0 & 0 & & 0 & & 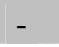 & 0 & 0 & 1 & 0 & & 0 & 0 & \\
\hline P.chilensis & 0 & 0 & 0 & 1 & 1 & 0 & 1 & 1 & 0 & 0 & 1 & 1 & 1 & 0 & 1 & 1 & 0 & 0 & 2 & 0 & - & 0 & 1 & 0 & 0 & 0 & 1 & 0 & & 1 & & 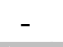 & 1 & 0 & 1 & 0 & 1 & 0 & 0 & - \\
\hline C.elegans & 2 & 0 & 2 & 1 & 1 & 1 & 0 & 1 & 2 & 0 & 1 & 1 & 0 & 1 & 1 & 1 & 0 & 1 & 1 & 1 & 0 & 0 & 1 & 0 & 0 & 0 & 1 & 0 & 0 & 1 & - & - & 0 & d & 1 & 0 & 0 & 0 & 0 & - \\
\hline D.testudineus & 1 & 0 & 2 & 0 & 1 & 2 & 1 & 1 & 0 & 0 & 1 & 1 & 0 & 1 & 1 & 1 & 0 & 1 & 0 & 1 & 1 & 0 & 1 & 0 & 0 & 0 & 0 & 0 & 1 & 2 & 0 & 0 & 1 & 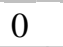 & 1 & 0 & 0 & 0 & 0 & - \\
\hline D.nigricans & 1 & 0 & 2 & 0 & 1 & 2 & U & 1 & 0 & 1 & 1 & 1 & 0 & 1 & 1 & 1 & 0 & 1 & 1 & 1 & 1 & 0 & 1 & 0 & 0 & 1 & 2 & 0 & 1 & 2 & 0 & 0 & 1 & 0 & 1 & 0 & 1 & 0 & 0 & - \\
\hline M.squalidus & 1 & 0 & 3 & 1 & 1 & 2 & 1 & 0 & 0 & 1 & 1 & 1 & 0 & 1 & 0 & 1 & 0 & 1 & 1 & 1 & 1 & 0 & 1 & 0 & 0 & 2 & 2 & 0 & 1 & 2 & 0 & 0 & 1 & 0 & 1 & 0 & 0 & 0 & 0 & - \\
\hline M.castanea & 3 & 0 & 2 & 1 & 1 & 1 & 1 & 0 & 1 & 1 & 1 & 1 & 0 & 1 & 1 & 1 & 0 & 2 & 1 & 1 & 1 & 0 & 1 & 0 & 0 & 2 & 1 & 0 & 1 & 2 & 0 & 0 & 1 & 0 & 1 & 0 & 2 & 1 & 0 & - \\
\hline N.guapimirim & 0 & 0 & 2 & 1 & 1 & 3 & 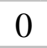 & 1 & 0 & 0 & 1 & 1 & 0 & 1 & 2 & 1 & 0 & 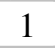 & 1 & 1 & 1 & 0 & 1 & 0 & 0 & 1 & 1 & 0 & 0 & 2 & & 1 & 0 & 0 & 1 & 0 & 0 & 1 & 1 & 0 \\
\hline N.bipustulatus & 0 & 0 & 2 & 1 & 1 & ? & 0 & 1 & 0 & 0 & 1 & 1 & 0 & 1 & 2 & 1 & 0 & 1 & 1 & 1 & 1 & 0 & 1 & 0 & 0 & 1 & 1 & 0 & 0 & 2 & & 0 & 1 & 0 & 1 & 0 & 0 & 0 & 0 & - \\
\hline N.gracilis & 0 & 0 & 2 & 1 & 1 & 1 & 0 & 1 & 0 & 0 & 1 & 1 & 0 & 1 & 2 & 1 & 0 & 1 & 1 & 1 & 1 & 0 & 1 & 0 & 0 & 1 & 0 & 0 & 0 & 2 & & 0 & 1 & 0 & 1 & 0 & 0 & 0 & 1 & - \\
\hline P.bellus & 0 & 1 & 2 & 1 & 1 & 2 & 1 & 0 & 0 & 1 & 1 & 1 & 1 & 1 & 1 & 1 & 1 & 2 & 2 & 1 & 1 & 1 & 1 & 1 & 0 & 1 & 0 & 0 & 1 & 2 & & 0 & 1 & 0 & 1 & 0 & 0 & 1 & 1 & 0 \\
\hline P.dificillis & 0 & 1 & 2 & 1 & 1 & 2 & 1 & 0 & 0 & 1 & 1 & 1 & 1 & 1 & 1 & 1 & 1 & 0 & & 1 & 1 & 1 & 1 & 1 & 0 & 1 & 1 & 1 & 1 & 2 & & 1 & 1 & 0 & 1 & $?$ & 1 & 1 & 1 & 1 \\
\hline P.ha & 0 & 1 & 2 & 1 & 1 & 2 & 1 & 0 & 0 & 1 & 1 & 1 & 1 & 1 & 1 & 1 & 1 & 2 & 2 & 1 & 1 & 1 & 1 & 1 & 0 & 1 & 1 & 1 & 1 & 2 & 0 & 0 & 1 & 1 & 1 & 1 & 1 & 2 & 0 & 1 \\
\hline P.hatschbachi2 & 0 & 1 & 2 & 1 & 1 & 2 & 1 & 0 & 0 & 1 & 1 & 1 & 1 & 1 & 1 & 1 & 1 & 0 & 2 & 1 & 1 & 1 & 1 & 1 & 0 & 1 & 1 & 1 & 2 & 2 & 0 & U & 1 & 1 & 1 & 1 & 1 & 1 & 0 & 1 \\
\hline P.orn & 0 & 1 & $?$ & 1 & 1 & 2 & 1 & 0 & 0 & 1 & 1 & 1 & 1 & 1 & 1 & 1 & 1 & 2 & 2 & 1 & 1 & 1 & 1 & 1 & 0 & 1 & 1 & 1 & & 2 & & 1 & 1 & 0 & 1 & 0 & 1 & 1 & 1 & 1 \\
\hline P.ornatus? & 0 & 1 & 2 & 1 & 1 & 2 & 1 & 0 & 0 & 1 & 1 & 1 & 1 & 1 & 1 & 1 & 1 & 2 & 2 & 1 & 1 & 1 & 1 & 1 & 0 & 1 & 1 & 1 & & 2 & & 1 & 1 & 0 & 1 & 1 & 1 & 1 & 1 & 1 \\
\hline P.ornatus3 & 0 & 1 & 2 & 1 & 1 & 2 & 1 & 0 & 0 & 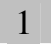 & 1 & 1 & 1 & 1 & 1 & 1 & 1 & 2 & 2 & 1 & 1 & 1 & 1 & 1 & 0 & 1 & 1 & 1 & 2 & 2 & & 1 & 1 & 0 & 1 & 0 & 1 & 2 & 1 & 1 \\
\hline P.orne & 0 & 1 & 2 & 1 & 1 & 2 & 1 & 0 & 0 & 1 & 1 & 1 & 1 & 1 & 1 & 1 & 1 & 0 & 2 & 1 & 1 & 1 & 1 & 1 & 0 & 1 & 1 & 1 & 2 & 2 & & 1 & 1 & 0 & 1 & 0 & 1 & 1 & 1 & 1 \\
\hline P.viridigranulatus1 & 0 & 0 & 3 & 1 & 1 & 2 & 1 & 0 & 0 & 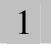 & 1 & 1 & 1 & 1 & 1 & 1 & 1 & 2 & 2 & 1 & 1 & 0 & 1 & 1 & 0 & 1 & 2 & 1 & 0 & 2 & & 1 & 0 & 1 & 0 & 1 & 0 & 0 & 1 & 1 \\
\hline P.viridigranulatus2 & 0 & 0 & 3 & 1 & 1 & 2 & 1 & 0 & 0 & 1 & 1 & 1 & 1 & 1 & 1 & 1 & 1 & 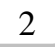 & & 1 & 1 & 0 & 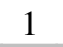 & 1 & 0 & 1 & 2 & 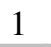 & 0 & 2 & & 1 & 1 & 1 & 1 & 1 & 0 & 0 & 1 & 1 \\
\hline Pro.s & 0 & 0 & 0 & 0 & 1 & 2 & 1 & 0 & 0 & 1 & 1 & 1 & 1 & 1 & 1 & 1 & 1 & 2 & 2 & 1 & 0 & 0 & 1 & 0 & 0 & 0 & 1 & 0 & 0 & 2 & 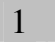 & 0 & 1 & 0 & 1 & 0 & 0 & 1 & 1 & 1 \\
\hline Pro. & 0 & 1 & $?$ & 1 & 1 & 2 & 1 & 0 & 0 & 1 & 1 & 1 & 1 & 1 & 1 & 1 & 1 & 2 & 2 & 1 & 1 & 1 & 1 & 1 & 0 & 1 & 1 & 1 & 0 & 2 & 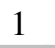 & 1 & 1 & 0 & 1 & 0 & 1 & 1 & 1 & 1 \\
\hline Pro & 0 & 1 & 0 & 1 & 1 & 2 & - & 0 & 0 & 1 & 1 & 1 & 1 & 1 & 1 & 1 & 1 & 2 & & 1 & 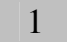 & 1 & 1 & 1 & 1 & 1 & 2 & 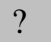 & 1 & 2 & 0 & 1 & 0 & 1 & 1 & 1 & 1 & 1 & 1 & 1 \\
\hline Pro. & 0 & 1 & 2 & 1 & 1 & 2 & 1 & 0 & 0 & 1 & 1 & 1 & 1 & 1 & 1 & 1 & & 2 & 2 & 1 & 1 & 0 & 1 & 1 & 0 & 1 & 2 & 1 & 2 & 2 & & 1 & 0 & 1 & 0 & 1 & 0 & 1 & & 1 \\
\hline I.ter & 1 & 0 & 2 & 1 & 1 & ? & 0 & 1 & 0 & 0 & 1 & 1 & ( & 1 & 1 & 1 & 0 & 2 & 1 & 1 & 1 & 0 & 0 & 0 & 0 & 2 & 0 & 0 & & 2 & & 0 & 1 & 0 & 1 & 0 & 1 & 1 & 0 & - \\
\hline I.par & 1 & 0 & 2 & 1 & 1 & 2 & 0 & 1 & 0 & 0 & 1 & 1 & 0 & 1 & 1 & 1 & 0 & 2 & 1 & 1 & 1 & 0 & 0 & 0 & 0 & 2 & 0 & 0 & 2 & 2 & 0 & 0 & 1 & 0 & 1 & 0 & 1 & 0 & 0 & - \\
\hline R.vellutina & 2 & 0 & 2 & 1 & 1 & 1 & 1 & 0 & 0 & 1 & 1 & 1 & 0 & 1 & 1 & 1 & 0 & 1 & 1 & 1 & 1 & 0 & 0 & 0 & 0 & 2 & 0 & 0 & 2 & 1 & 0 & 0 & 1 & 0 & 1 & 0 & 0 & 0 & 0 & \\
\hline R.maculata & 3 & 0 & 2 & 1 & 1 & 1 & 1 & 0 & 0 & 1 & 1 & 1 & 0 & 1 & 1 & 1 & 0 & 1 & 1 & 1 & 1 & 0 & 1 & 0 & 0 & - & 0 & 0 & 1 & 2 & 0 & 0 & 1 & 0 & 1 & 0 & 0 & 0 & 0 & - \\
\hline E.montanum & ? & 0 & 0 & 1 & 1 & 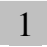 & 1 & 0 & 0 & 1 & 1 & 1 & 0 & 1 & 1 & 1 & 0 & 1 & 1 & 1 & 1 & 0 & 0 & 0 & 0 & 2 & 0 & 0 & 1 & 2 & 0 & 0 & 1 & 0 & 1 & 0 & 0 & 0 & 0 & \\
\hline E.ruschii & 0 & 0 & 2 & 1 & 1 & 1 & 1 & 0 & 0 & 1 & 1 & 1 & 0 & 1 & 1 & 1 & 0 & 1 & 1 & 1 & 1 & 0 & 0 & 0 & 0 & 2 & 0 & 0 & 2 & 2 & 0 & 0 & 1 & 0 & 1 & 0 & 1 & 0 & 0 & - \\
\hline D.parvulus & 0 & 0 & 2 & 1 & 1 & 2 & 1 & 1 & 0 & 0 & 1 & 1 & ( & 1 & 3 & 1 & 0 & 1 & 0 & 1 & 1 & 0 & 0 & 0 & 0 & 1 & 0 & 0 & 2 & 1 & & - & 1 & 0 & 1 & 0 & 2 & 0 & 1 & 0 \\
\hline M.pulcher & 2 & 0 & 2 & 1 & 1 & 1 & 1 & 1 & 1 & 1 & 1 & 1 & 0 & 1 & $\sigma$ & 0 & & 2 & & 1 & 1 & 0 & 1 & 1 & 0 & 2 & 1 & ? & 1 & 2 & 0 & 0 & 1 & 0 & 1 & 0 & 2 & 0 & 0 & \\
\hline M.in & ? & 0 & 2 & 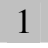 & 1 & 1 & 1 & 1 & ? & 1 & 1 & 1 & 0 & 1 & 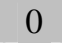 & c & - & 2 & $?$ & 1 & 1 & 0 & 1 & 0 & 0 & 2 & 1 & 0 & 1 & 0 & & - & 1 & 0 & 1 & 0 & 2 & 0 & 0 & \\
\hline M.tr & 3 & 0 & 2 & 0 & 1 & 1 & 1 & 1 & 0 & 1 & 1 & 1 & 0 & 1 & V & 0 & - & 2 & 1 & 1 & 1 & 0 & 1 & 1 & 0 & 2 & 1 & 0 & 1 & 2 & 0 & 0 & 1 & 0 & 1 & 0 & 2 & 0 & 0 & - \\
\hline L.concolor & 0 & 0 & 3 & 1 & 0 & 1 & 0 & 1 & 0 & 0 & 1 & 1 & 0 & 1 & 1 & 1 & 0 & 1 & 1 & 1 & 1 & 0 & 1 & 0 & 0 & 1 & ? & 0 & 2 & 2 & 0 & 0 & 1 & 0 & 1 & 0 & 1 & 0 & 0 & \\
\hline
\end{tabular}


L.cancellata \begin{tabular}{|lllllllllllllllllllllllllllllllllllllllll}
1 & 0 & 3 & 1 & 0 & 1 & 0 & 1 & 0 & 0 & 1 & 1 & 0 & 1 & 1 & 1 & 0 & 1 & 1 & 1 & 1 & 1 & 1 & 0 & 0 & 1 & $?$ & 0 & 2 & 2 & 0 & 0 & 0 & 0 & 1 & 0 & 1 & 0 & 0 & - \\
0 & 0 & 2 & 0 & 1 & 1 & 0 & 1 & 0 & 0 & 1 & 1 & 0 & 1 & 1 & 1 & 0 & 1 & 1 & 1 & 1 & 0 & 1 & 0 & 0 & 1 & 2 & 0 & 2 & 2 & 0 & 0 & 0 & 0 & 1 & 0 & 2 & 1 & 0 & - \\
0 & 0 & 2 & 0 & 1 & 1 & 0 & 1 & 0 & 0 & 1 & 1 & 0 & 1 & 1 & 1 & 0 & 1 & 1 & 1 & 1 & 1 & 1 & 0 & 0 & 1 & 1 & 0 & 2 & 2 & 0 & 0 & 0 & 0 & 1 & 0 & 1 & 0 & 0 & -
\end{tabular}

\section{L.coxalis}

L.insperata $\begin{array}{lllllllllllllllllllllllllllllllllllllllllllll}0 & 0 & 2 & 0 & 1 & 1 & 0 & 1 & 0 & 0 & 1 & 1 & 0 & 1 & 1 & 1 & 0 & 1 & 1 & 1 & 1 & 1 & 1 & 0 & 0 & 1 & 1 & 0 & 2 & 2 & 0 & 0 & 0 & 0 & 1 & 0 & 1 & 0 & 0 & -\end{array}$

Tabela 02. Matriz de 75 caracteres utilizados na análise cladística de Mitobatinae (Opiliones, Gonyleptidae), separada por região do corpo. \begin{tabular}{|c|c|c|}
\hline & E.D & APÊNDICES
\end{tabular}

\begin{tabular}{|c|c|c|c|c|c|c|c|c|c|c|c|c|c|c|c|c|c|c|c|c|c|c|c|c|c|c|c|c|c|c|c|c|c|c|c|}
\hline \multirow{3}{*}{ TAXA } & \multirow{2}{*}{\multicolumn{3}{|c|}{$\begin{array}{c}\text { E.D } \\
\text { Tergitos } \\
\text { livres }\end{array}$}} & \multicolumn{22}{|c|}{ APÊNDICES } & \multirow{2}{*}{\multicolumn{7}{|c|}{ COLORAÇÃO }} & \multirow{2}{*}{\multicolumn{3}{|c|}{ OUTROS }} \\
\hline & & & & \multicolumn{2}{|c|}{ pedipalpo } & \multicolumn{11}{|c|}{ coxa IV } & \multicolumn{5}{|c|}{ trocanter IV } & \multicolumn{3}{|c|}{ fêmur IV } & & & & & & & & & & & \\
\hline & 41 & 42 & 43 & 44 & 45 & 46 & 47 & 48 & 49 & 50 & 51 & 52 & 53 & 54 & 55 & 56 & 57 & 58 & 59 & 60 & 61 & 62 & 63 & 64 & 65 & 66 & 67 & 68 & 69 & 70 & 71 & 72 & 73 & 74 & 75 \\
\hline C.picea & 0 & 0 & 0 & 0 & 0 & 0 & 0 & 1 & 0 & - & 0 & 2 & 0 & 1 & 0 & 0 & 1 & 0 & 1 & 0 & 1 & 0 & 1 & 0 & 0 & 0 & 0 & 0 & 0 & 0 & 0 & 0 & 0 & 0 & 0 \\
\hline B.albiornatc & 0 & 0 & 0 & 1 & 1 & 1 & 1 & 1 & 1 & 0 & 1 & 0 & 0 & 1 & 0 & 0 & 2 & 1 & 1 & 0 & 1 & 1 & 1 & 1 & 0 & 0 & 0 & 0 & 0 & 0 & 0 & 0 & 0 & 0 & 0 \\
\hline P.chilensis & 0 & 0 & 0 & 0 & $?$ & 1 & 0 & 1 & 1 & 1 & 1 & 1 & 0 & 0 & - & - & 0 & 0 & 1 & 0 & 1 & 0 & 1 & 0 & 0 & 0 & 0 & 0 & 0 & 0 & 0 & 0 & 0 & 0 & 0 \\
\hline C.elegans & 0 & 0 & 0 & 1 & 1 & 1 & 1 & 1 & 0 & - & 0 & 2 & 0 & 1 & 0 & 0 & 1 & 0 & 1 & 0 & 0 & 1 & 1 & 1 & 0 & 0 & 0 & 0 & 1 & 0 & 0 & 0 & 0 & 0 & 0 \\
\hline D.testudineus & 0 & 0 & 0 & 1 & 1 & 1 & 0 & 1 & 0 & - & 0 & 2 & 0 & 1 & 0 & 0 & 2 & 0 & 1 & 1 & 1 & 0 & 1 & 0 & 0 & 0 & 0 & 0 & 0 & 0 & 0 & 0 & 1 & 0 & 0 \\
\hline D. nigricans & 0 & 0 & 0 & 0 & 1 & 1 & 1 & 1 & 1 & 1 & 1 & 0 & 0 & 1 & 1 & 1 & 2 & 0 & 1 & 1 & 0 & 2 & 0 & 1 & 1 & 0 & 0 & 0 & 0 & 0 & 0 & 0 & 0 & 1 & 1 \\
\hline M.squalidus & 0 & 0 & 0 & 0 & 1 & 0 & 0 & 0 & - & - & - & - & - & 0 & - & - & 2 & 0 & 0 & 0 & 0 & 2 & 0 & 1 & 1 & 0 & 0 & 0 & - & 0 & 0 & 0 & 0 & 1 & 1 \\
\hline M.castanea & 0 & 0 & 0 & 1 & 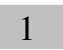 & 0 & 0 & 0 & - & - & - & - & - & 0 & - & - & 2 & 0 & 0 & 0 & 0 & 2 & 0 & 1 & 1 & 1 & 1 & 0 & - & 0 & 0 & 0 & 1 & 1 & 1 \\
\hline N.guapimirim & 0 & 0 & 0 & 0 & 1 & 1 & 1 & 1 & 1 & 1 & 1 & 1 & 0 & 1 & 0 & 0 & 2 & 1 & 1 & 0 & 1 & 1 & 0 & 1 & 1 & 0 & 0 & 0 & 0 & 0 & 0 & 0 & 0 & 1 & 1 \\
\hline N.bipustulatus & 0 & 0 & U & 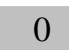 & 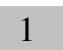 & 1 & 1 & 1 & 1 & 1 & 1 & 1 & 0 & 1 & 0 & 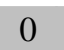 & $L$ & 1 & 1 & 0 & 1 & 1 & 0 & 1 & 1 & 0 & 0 & 0 & 0 & 0 & 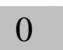 & 0 & 0 & 1 & 1 \\
\hline N.gracilis & 0 & 0 & 0 & 0 & 1 & 1 & 1 & 1 & 1 & 1 & 1 & 1 & 0 & 1 & 0 & 0 & 2 & 1 & 1 & 0 & 1 & 1 & 0 & 1 & 1 & 0 & 0 & 0 & 0 & 0 & 0 & 0 & 0 & 1 & 1 \\
\hline P.bellus & 0 & 0 & 0 & 1 & 1 & 1 & 1 & 1 & 1 & 1 & 1 & 0 & 0 & 1 & 0 & 0 & 2 & 1 & 1 & 0 & 1 & 2 & 0 & 1 & 1 & 0 & 0 & 0 & 0 & 0 & 0 & 0 & 1 & 1 & 1 \\
\hline P.dificillis & 1 & 0 & 0 & 1 & 1 & 1 & 1 & 1 & 1 & 1 & 1 & 1 & 1 & 1 & 0 & 0 & 2 & 1 & 1 & 0 & 1 & 2 & 0 & 1 & 1 & 1 & 1 & 0 & 0 & 0 & 0 & 0 & 1 & 1 & 1 \\
\hline P.hatschbachi1 & 1 & 0 & 0 & 1 & 1 & 1 & 1 & 1 & 1 & 1 & 1 & 1 & 0 & 1 & 0 & 0 & 2 & 1 & 1 & 0 & 1 & 2 & 0 & 1 & 1 & 1 & 0 & 0 & 0 & 0 & 0 & 0 & 0 & 1 & 1 \\
\hline P.hatschbachi2 & 1 & 0 & 1 & 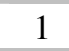 & 1 & 1 & 1 & 1 & 1 & 1 & 1 & 1 & 0 & 1 & 0 & 0 & 2 & 1 & 1 & 0 & 1 & 2 & 0 & 1 & 1 & 1 & 0 & 0 & 0 & 0 & 0 & 0 & 0 & 1 & 1 \\
\hline P.ornatus1 & 1 & 0 & 0 & 1 & 1 & 1 & 1 & 1 & 1 & 1 & 1 & 1 & 0 & 1 & 0 & 0 & 2 & 1 & 1 & 0 & 1 & 2 & 0 & 1 & 1 & 0 & 1 & 0 & 0 & 0 & 0 & 0 & 0 & 1 & 1 \\
\hline P.ornatus2 & 1 & 0 & 0 & 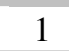 & 1 & 1 & 1 & 1 & 1 & 1 & 1 & 1 & 0 & 1 & 0 & 0 & 2 & 1 & 1 & 0 & 1 & 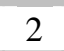 & 0 & 1 & 1 & 0 & 1 & 0 & 0 & 0 & 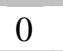 & 0 & 0 & 1 & 1 \\
\hline P.ornatus3 & 1 & 0 & 1 & 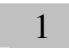 & 1 & 1 & 1 & 1 & 1 & 1 & 1 & 1 & 0 & 1 & 0 & 0 & 2 & 1 & 1 & 0 & 1 & 2 & 0 & 1 & 1 & 0 & 1 & 0 & 0 & 0 & 0 & 0 & 0 & 1 & 1 \\
\hline P.ornatus4 & 1 & 0 & 1 & 1 & 1 & 1 & 1 & 1 & 1 & 1 & 1 & 1 & 0 & 1 & 0 & 0 & 2 & 1 & 1 & 0 & 1 & 2 & 0 & 1 & 1 & 0 & 1 & 0 & 0 & 0 & 0 & 0 & 0 & 1 & 1 \\
\hline P.viridigranulatus1 & 1 & 0 & 0 & 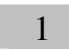 & 1 & 1 & 1 & 1 & 1 & 1 & 1 & 0 & 1 & 1 & 0 & 0 & 2 & 1 & 1 & 0 & 1 & 2 & 0 & 1 & 1 & 0 & 0 & 0 & 0 & 0 & 0 & 0 & 1 & 1 & 1 \\
\hline P.viridigranulatus2 & 1 & 0 & 0 & 1 & 1 & 1 & 1 & 1 & 1 & 1 & 1 & 0 & 1 & 1 & 0 & 0 & 2 & 1 & 1 & 0 & 1 & 2 & 0 & 1 & 1 & 0 & 0 & 0 & 0 & 0 & 0 & 0 & 1 & 1 & 1 \\
\hline Pro.sp.n 1 & 0 & 1 & 0 & 1 & 1 & 1 & 1 & 1 & 0 & - & 1 & 0 & 1 & 1 & 0 & 0 & 2 & 1 & 1 & 0 & 1 & 2 & 0 & 1 & 1 & 0 & 0 & 0 & 1 & 0 & 0 & 0 & 1 & 1 & 1 \\
\hline Pro.sp.n2 & 1 & 0 & 1 & 1 & 1 & 1 & 1 & 1 & 0 & - & 1 & 0 & 1 & 1 & 0 & 0 & 2 & 1 & 1 & 0 & 1 & 2 & 0 & 1 & 1 & 1 & 0 & 0 & 1 & 1 & 0 & 0 & 1 & 1 & 1 \\
\hline Pro.sp.n4 & 1 & 0 & 0 & 1 & 1 & 1 & 1 & 1 & 1 & 1 & 1 & 1 & 0 & 1 & 0 & 0 & 2 & 1 & 1 & 0 & 1 & 2 & 0 & 1 & 1 & 0 & 0 & 0 & 0 & 0 & 0 & 0 & 1 & 1 & 1 \\
\hline Pro.sp.n3 & 0 & 0 & 0 & 1 & 1 & 1 & 1 & 1 & 1 & 0 & 1 & 0 & 1 & 1 & 0 & 0 & 2 & 1 & 1 & 0 & 1 & 2 & 0 & 1 & 1 & 0 & 0 & 0 & 1 & 1 & 0 & 0 & 1 & 1 & 1 \\
\hline I.tenebros & 0 & 0 & 0 & 0 & 1 & 0 & 0 & 0 & - & - & - & - & - & 0 & - & - & 2 & 0 & 0 & 0 & 0 & 2 & 0 & 1 & 1 & 0 & 0 & 0 & 0 & 0 & 1 & 1 & 0 & 0 & 1 \\
\hline I.pardus & 0 & 0 & 0 & 0 & 1 & 0 & 0 & 0 & - & - & - & - & - & 0 & - & - & 2 & 0 & 0 & 0 & 0 & 2 & 0 & 1 & 1 & 0 & 0 & 0 & - & 0 & 1 & 1 & 0 & 0 & 1 \\
\hline R.vellutina & 0 & 0 & 0 & 1 & 1 & 0 & 0 & 0 & - & - & - & - & - & 0 & - & - & 2 & 0 & 0 & 0 & 0 & 2 & 0 & 1 & 1 & 0 & 0 & 1 & - & 0 & 0 & 0 & 0 & 1 & 1 \\
\hline R.maculata & 0 & 0 & 0 & 1 & 1 & 0 & 0 & 0 & - & - & - & - & - & 0 & - & - & 2 & 0 & 0 & 0 & 0 & 2 & 0 & 1 & 1 & 0 & 0 & 1 & - & 0 & 1 & 0 & 0 & 1 & 1 \\
\hline E.montanum & 0 & 0 & 0 & 0 & 1 & 0 & 0 & 1 & 0 & - & - & 3 & 0 & 0 & - & - & 2 & 0 & 0 & 0 & 0 & 2 & 0 & 1 & 1 & 0 & 0 & 0 & 0 & 0 & 0 & 0 & 0 & 0 & 1 \\
\hline E.ruschii & 0 & 0 & 0 & 0 & 1 & 0 & 0 & 1 & 0 & - & - & 3 & 0 & 0 & - & - & 2 & 0 & 0 & 0 & 0 & 2 & 0 & 1 & 1 & 0 & 0 & 0 & 0 & 0 & 0 & 0 & 0 & 0 & 1 \\
\hline D.parvulus & 0 & 0 & 0 & $?$ & 1 & 0 & 0 & 1 & 0 & - & 1 & 0 & 0 & 1 & 0 & 0 & 2 & 0 & 1 & 0 & 1 & 1 & 1 & 1 & 0 & 0 & 0 & 0 & 0 & 0 & 0 & 0 & 0 & 0 & 1 \\
\hline M.pulcher & 0 & 0 & 0 & 1 & 1 & 0 & 0 & 0 & - & - & - & - & - & 0 & - & - & 2 & 0 & 0 & 0 & 0 & 2 & 0 & 1 & 1 & 1 & 1 & 0 & - & 0 & 0 & 0 & 0 & 1 & 1 \\
\hline
\end{tabular}


